\title{
Linguagem, educação e virtualidade
}

\author{
Ucy Soto \\ Mônica Ferreira Mayrink \\ Isadora Valencise Gregolin \\ (orgs.)
}

SOTO, U., MAYRINK, MF., and GREGOLIN, IV., orgs. Linguagem, educação e virtualidade [online]. São Paulo: Editora UNESP; São Paulo: Cultura Acadêmica, 2009. 249 p. ISBN 978-857983-017-4. Available from SciELO Books <http://books.scielo.org>.

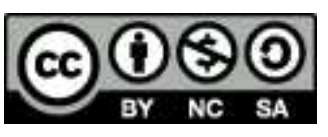

All the contents of this work, except where otherwise noted, is licensed under a Creative Commons Attribution-Non Commercial-ShareAlike 3.0 Unported.

Todo o conteúdo deste trabalho, exceto quando houver ressalva, é publicado sob a licença Creative Commons Atribuição Uso Não Comercial - Partilha nos Mesmos Termos 3.0 Não adaptada.

Todo el contenido de esta obra, excepto donde se indique lo contrario, está bajo licencia de la licencia Creative Commons Reconocimento-NoComercial-CompartirIgual 3.0 Unported. 


\section{LINGUAGEM, EDUCAÇÃO E VIRTUALIDADE EXPERIÊNCIAS E REFLEXÕES \\ UCY SOTO MỐNICA FERREIRA MAYRINK ISADORA VALENCISE GREGOLIN ORGANIZADORAS}




\section{LINGUAGEM, EDUCAÇÃO E VIRTUALIDADE}





\section{UCY SOTO \\ MÔNICA FERREIRA MAYRINK ISADORA VALENCISE GREGOLIN \\ ORGANIZADORAS}

\section{LINGUAGEM, EDUCAÇÃO E VIRTUALIDADE EXPERIÊNCIAS E REFLEXÕES}




\section{(C) 2009 Editora UNESP}

\section{Cultura Acadêmica}

Praça da Sé, 108

01001-900 - São Paulo - SP

Tel.: (0xx1 1) 3242-7171

Fax: $(0 x \times 11) 3242-7172$

www.editoraunesp.com.br

feu@editora.unesp.br

CIP- Brasil. Catalogação na fonte

Sindicato Nacional dos Editores de Livros, RJ

L727

Linguagem, educação e virtualidade / Ucy Soto, Mônica Ferreira Mayrink, Isadora Valencise Gregolin, organizadoras. - São Paulo :

Cultura Acadêmica, 2009.

249p.

Inclui bibliografia

ISBN 978-85-7983-017-4

1. Ensino auxiliado por computador. 2. Educação-Recursos de redes de computadores. 3. Internet na educação. 4. Ensino à distância. 5. Comunicação e tecnologia. 6. Linguagem e línguas - Ensino auxiliado por computador. 7. Tecnologia educacional. I. Soto, Ucy. II. Mayrink, Mônica Ferreira. III. Gregolin, Isadora Valencise.

09-6224 
Sim, por mais estranho e repugnante que possa parecer-vos, as novas máquinas de ensino capacitam o estudante a aprender tanto quanto antes.

Além disso, os estudantes parecem ter mais confiança no novo método como meio de adquirir conhecimentos novos de toda sorte.

Pedro Ramus (1515-1572) A respeito do livro impresso 



\section{SUMÁRIO}

Apresentação 9

Formação tecnológica de professores: problematizando, refletindo, buscando...

Maximina Maria Freire 13

Educação virtual e virtualidade digital: trabalho pedagógico na educação a distância na Idade Mídia

Daniel Mill 29

O métier do professor em contexto digital

Anise A. G. D'Orange Ferreira 53

Nuevas tecnologías y su uso en educación

Miguel López Coronado,

Beatriz Sainz e

María Agustina Navazo 69

Design de material didático on-line: reflexões

Rosinda de Castro Guerra Ramos 93 
Concepção, design e ferramentas de um ambiente virtual colaborativo de ensino-aprendizagem de língua espanhola Ucy Soto, Isadora Valencise Gregoline Marcelo Rangel 117

O ambiente virtual de aprendizagem (Moodle) como ferramenta auxiliar no processo ensino-aprendizagem: uma questão de comunicação

Márcia Helena Sauáia Guimarães Rostas e Guilherme Ribeiro Rostas 135

Deutschkurs Kulturenannäherung: uma proposta para a formação continuada on-line de professores

Cibele Cecílio de Faria Rozenfeld e Ana Maria de Senzi Moraes Pinto 153

Graus de interação no espaço físico e virtual Paulo Oliveira 175

Interesses e necessidades de uso da internet da perspectiva de alunos de Letras - Espanhol

Mônica Ferreira Mayrink 191

O papel da mediação pedagógica em fóruns educacionais de cursos on-line de língua estrangeira

Kátia Silene Gabrielli 209

Uso do chat na sala de aula de língua espanhola: uma proposta a partir da análise do gênero

Crisciene Lara Barbosa-Paiva 225

Sobre os autores 241 


\section{ApresentaÇÃo}

Pensamos não haver como negar que uma educação que transcende os muros da sala de aula e se abre para as linguagens e as práticas do mundo moderno se torna, necessariamente, mais complexa e ainda menos transparente. Para essa complexidade contribuem, em grande medida, as novas ferramentas tecnológicas que se fazem cada vez mais presentes no processo de ensinar e aprender línguas. Essa presença, desejada por alguns e temida por outros, não está livre de ambiguidades, muito pelo contrário. No âmbito acadêmico, pesquisadores jovens ou experientes buscam, a partir de suas práticas e reflexões teóricas, compreender novas demandas que incidam diretamente em áreas como a formação inicial e continuada de professores, o trabalho docente em aula presencial e virtual, o design de materiais didáticos e a forma como os novos meios e práticas atuam no funcionamento da linguagem e na criação de novos gêneros discursivos.

Os artigos presentes nesta coletânea são fruto do intercâmbio de trabalhos apresentados durante o II Encontro CAPES-MECD/ DGU: linguagem, educação e virtualidade, realizado em 2008 na Faculdade de Ciências e Letras da Universidade Estadual Paulista "Júlio de Mesquita Filho" - UNESP, no campus de Araraquara. O encontro foi organizado pelo grupo de pesquisa do CNPq Linguagem, Educação e Virtualidade (LEV) com apoio do Programa de Pós-Graduação em Linguística e Língua Portuguesa e do Projeto 
de Cooperação Internacional CAPES-MECD/DGU no 123/06, ${ }^{1}$ que reúne professores e alunos da Universidad de Valladolid (Espanha), da UNESP - Araraquara (SP) e da Universidade Federal Fluminense (RJ). O evento, que enfocou de forma multidisciplinar as temáticas apresentadas no título do encontro, contou com a participação de convidados de renomadas instituições de ensino superior nacionais e internacionais e com a participação de alunos de programas de pós-graduação, que apresentaram resultados de projetos de pesquisa finalizados ou em andamento.

No artigo "Formação tecnológica de professores: problematizando, refletindo, buscando...”, Maximina Maria Freire revisa as concepções da formação docente com o propósito de buscar diretrizes para uma formação tecnológica que contemple as necessidades da sociedade atual. $\mathrm{O}$ texto aporta conceitos fundamentais da área de formação de professores e apresenta um novo entendimento de formação tecnológica.

No texto "Educação virtual e virtualidade digital: trabalho pedagógico na educação a distância na Idade Mídia”, Daniel Mill analisa as mudanças pelas quais o fazer pedagógico, os tempos e os espaços pedagógicos e a educação formal passaram durante o processo de virtualização da educação. $\mathrm{O}$ autor apresenta a relação entre educação e virtualidade na contemporaneidade, tendo como campo de observação o processo de trabalho na educação virtual a distância.

Anise A. G. D’Orange Ferreira, em "O métier do professor em contexto digital”, parte de experiências pessoais com ensino de línguas para tratar do trabalho de ensino de professores que atuam no contexto digital. A autora chama a atenção para a necessidade de se repensar o papel dos professores, a carga horária e a estrutura dos cursos. Estabelece, também, uma comparação entre cursos presencias, cursos totalmente a distância e cursos na modalidade blended learning.

Miguel López Coronado, Beatriz Sainz e María Agustina

1 O projeto se intitula "Ambiente híbrido para a aprendizagem (blended learning) de espanhol língua estrangeira: construção de uma proposta didático-pedagógica”. 
Navazo, no artigo "Nuevas tecnologías y su uso en educación", apresentam diversos conceitos fundamentais na área de educação a distância com o uso da web 2.0, destacando-se componentes tecnológicos como o Gigapop e IPV6. Discutem a evolução de diferentes tipos de tecnologia e sua importância para a criação e o desenvolvimento de comunidades virtuais de aprendizagem e tratam do papel das Tecnologias da Informação e Comunicação (TICs) na sociedade espanhola atual.

O artigo de Rosinda de Castro Guerra Ramos, "Design de material didático on-line: reflexões", apresenta alguns questionamentos que contribuem para as demandas geradas pelas premissas da sociedade do conhecimento em sintonia com as TICs. Trata de questões relativas à conceituação de material didático e seu design, fazendo, a seguir, um paralelo com o advento do computador e ilustrando com exemplos de material didático elaborado para cursos on-line.

Ucy Soto, Isadora Valencise Gregolin e Marcelo Rangel, no artigo "Concepção, design e ferramentas de um ambiente virtual colaborativo de ensino-aprendizagem de língua espanhola”, discutem os aspectos do design e da maneira como ferramentas e recursos podem ser articulados na montagem de um curso virtual de ensino-aprendizagem, tomando como exemplo o curso de extensão Español para turismo, oferecido pela UNESP - Araraquara.

Márcia Helena Sauáia Guimarães Rostas e Guilherme Ribeiro Rostas, em "O ambiente virtual de aprendizagem (Moodle) como ferramenta auxiliar no processo ensino-aprendizagem: uma questão de comunicação", analisam as potencialidades dos recursos tecnológicos disponíveis no ambiente virtual Moodle e discutem a formação de professores por meio do relato de experiência de um curso on-line oferecido pelo Instituto Federal de Educação do Maranhão.

No artigo "Deutschkurs Kulturenannäherung: uma proposta para a formação continuada on-line de professores”, Cibele C. de Faria Rozenfeld e Ana Maria de Senzi M. Pinto tratam do processo de elaboração de um curso on-line para professores de alemão, apresentam os preceitos teóricos que deram suporte à sua concepção e descrevem os tipos de materiais e atividades trabalhados durante o curso. 
O texto de Paulo Oliveira, "Graus de interação no espaço físico e virtual”, apresenta experiência de ensino da língua alemã nos ambientes virtuais Teleduc e Moodle. $\mathrm{O}$ autor esboça um panorama histórico dos graus de interação em diferentes formatos de aulas e apresenta o relato de um curso no formato híbrido, que explora as vantagens das mídias em suporte tradicional e leva em conta dificuldades técnicas e resistências culturais de seu público-alvo.

Mônica Ferreira Mayrink relata em seu artigo "Interesses e necessidades de uso da internet sob a perspectiva de alunos de Letras - Espanhol" uma pesquisa feita com alunos da UNESP - Araraquara. O texto apresenta algumas reflexões a respeito do perfil dos alunos e dos desafios presentes na formação inicial de professores, no que se refere à utilização de TICs.

Kátia Silene Gabrielli, em "O papel da mediação pedagógica em fóruns educacionais de cursos on-line de língua estrangeira", apresenta resultados de análises de interações em fóruns educacionais de um curso de espanhol para turismo. A autora problematiza o papel do professor como mediador em cursos a distância e discute conceitos pertinentes à área.

Crisciene Lara Barbosa-Paiva, em seu artigo "Uso do chat na sala de aula de língua espanhola: uma proposta a partir da análise do gênero", advoga a favor do uso do chat no âmbito educativo, a partir da análise do estilo de linguagem manifestada nesse gênero.

As temáticas tratadas nesta coletânea se articulam em torno de diferentes eixos que têm foco nas questões de linguagem, de ensino-aprendizagem de línguas e de uso de novas tecnologias, com destaque para a internet. Nesse contexto de transição, oferece a professores, alunos e pesquisadores um espaço de reflexão e intercâmbio de experiências acerca do que vem acontecendo nessa "Idade Mídia”. 


\title{
FORMAÇÃO TECNOLÓGICA DE PROFESSORES: PROBLEMATIZANDO, REFLETINDO, BUSCANDO...
}

\author{
Maximina Maria Freire \\ Pontifícia Universidade Católica de São Paulo
}

Umas dúvidas, umas inquietações, uma certeza de que as coisas estão sempre se fazendo e se refazendo e, em lugar de inseguro, me sentia firme na compreensão que, em mim, crescia de que a gente não é, de que a gente está sendo.

Paulo Freire (1995, p.79)

Sobretudo nas duas últimas décadas, as pesquisas nas áreas de Linguística Aplicada e Educação têm revelado uma tendência acentuada para o questionamento de concepções de ensino-aprendizagem e de orientações para a formação e o desenvolvimento de professores. Durante esse período, as discussões têm retomado, com nítida insistência, paradigmas educacionais (Moraes, 2002) e teorias de aprendizagem (Giusta, 2003), escrutinando-os para melhor compreender as práticas vigentes e sua (in)compatibilidade com o contexto histórico-social, que, se transformando rapidamente em vários aspectos, passa a ser caracterizado, também, pela inclusão de ferramentas de natureza tecnológica que demandam a utilização de novas linguagens e a adoção de novos procedimentos.

Em um contexto de transição - de um conjunto de concepções vigentes que não mais respondem às exigências de uma sociedade em transformação para um conjunto de concepções emergentes que, pela novidade, ainda requerem tempo para entendimento, aceitação 
e implementação -, encontramo-nos diante de um dilema que nos leva a repensar o enfoque até então dado ao processo ensino-aprendizagem e à formação docente, buscando consolidar ou redimensionar perspectivas e práticas. A experiência de problematizar, refletir, investigar e interpretar tem resultado em um mapeamento cada vez mais detalhado de possíveis contextos pedagógicos, levando-nos a ansiar medidas concretas que viabilizem ações que, por sua vez, repercutam no realinhamento da educação às necessidades e expectativas de uma sociedade que, dinâmica e sob influências de várias naturezas, também se encontra em processo de digitalização.

O ponto de partida para esse realinhamento parece estar no entendimento da própria sociedade e dos traços que a caracterizam atualmente. $\mathrm{O}$ contexto social em que vivemos é marcado pela rapidez e imediatismo proporcionados por novas modalidades de acesso, armazenamento, recuperação e intercâmbio de informações. Essa caracterização não apenas nos coloca diante de possibilidades únicas de construção e manipulação de conhecimentos, mas, também, origina formas distintas de trabalho, comunicação e interação com o meio, com o outro e com o próprio indivíduo. Parece haver urgência no desenvolvimento de competências e habilidades que respondam mais adequadamente às especificidades desse contexto, à necessidade de um pensar e fazer diferenciados, à carência de instrumentos e metodologias que sejam adequadas a uma percepção inusitada de tempo e espaço e a uma motivação singular para ensinar e aprender (Freire, 2005a, 2005b, 2006, 2007a, 2007b, 2008). O acesso às novas tecnologias viabiliza outras interfaces, práticas e linguagens, compelindo-nos a lidar com multiletramentos e a considerar requisitos originais tanto para o pertencimento de grupos específicos como para a definição do que poderia ser considerado inclusão ou exclusão. Constatamos que a sociedade contemporânea prioriza uma articulação não linear, não fragmentada, rizomática ${ }^{1}$ e, portanto, complexa, dos

1 Refiro-me, aqui, ao conceito de rizoma apresentado por Deleuze e Guatari (1972; 1980) e mencionado por Lévy (1996, p.152), no intuito de enfatizar a não linearidade e a complexidade da relação entre o todo e as partes, entendida como seu traço mais representativo. 
elementos que, de maneira ordenadamente desordenada, a compõem, revelando uma tessitura dinâmica, indicadora da interconectividade e interdependência que caracteriza o todo e suas partes (Morin, 1996a, 1996b, 2005a, 2005b; Moraes, 2002; Demo, 2002).

Nesse cenário social intrincado e em contínua transformação, surgem novas perspectivas educacionais e, consequentemente, novos papéis e responsabilidades são atribuídos a professores e alunos. Em termos epistemológicos, o paradigma emergente, segundo Moraes (2002, p.75), descarta a concepção tradicional de conhecimento disciplinar, fragmentado em "blocos fixos e imutáveis" para, como forma de reação à percepção paradigmática precedente (que o define como transmissível), enfatizar a noção de "conhecimento em rede". Nessa perspectiva, o aluno revela-se possuidor de necessidades, expectativas, exigências, habilidades e comportamentos distintos dos tradicionalmente definidos (Palloff \& Pratt, 2004); e, ao professor, são atribuídos os papéis de interlocutor, pesquisador reflexivo e intérprete crítico de sua prática. Essas funções encontram-se citadas, na literatura, com enfoques distintos. Kenski (2001, p.79-106), por exemplo, vê o professor como "agente de memória", "de valores" e "de inovações". Lopes (2005, p.40-52), por sua vez, discute as novas dimensões da atuação do professor, nomeando-o como "interface ativa", "promotor de associações e vínculos" e "promotor de sensibilidades".

Independente das nomeações possíveis e dos significados a elas atribuídos, uma contradição precisa ser ressaltada, pois o paradigma apontado como emergente (Moraes, 2002), apesar de resultante de descobertas marcantes, ocorridas a partir do início do século XX, ${ }^{2}$ ainda parece estar bem distante da realidade que, em geral, encontra-

2 Retomo a argumentação de Moraes (2002) que, citando Einstein, Bohm, Heisenberg e Prigogine (1986), aponta a teoria da relatividade, os princípios da complementaridade, o princípio da incerteza e a teoria das estruturas dissipativas e seus sistemas auto-organizadores como determinantes de um processo de mudança conceitual que, decorrente de uma crise e consequente ruptura com o paradigma tradicional cartesiano-newtoniano (caracterizado por uma visão mecanicista de mundo, vigente no final do século XIX), provoca uma nova forma de ver e pensar o mundo. 
mos nas instituições regulares de ensino. Nelas, há evidências de que o tempo flui em um ritmo extremamente mais lento do que aquele que conduz a evolução social, levando-nos a supor que, no âmbito escolar, as noções de tempo e espaço, zelosamente preservadas, são desconectadas da realidade. Embora inseridas em um único contexto histórico-cultural, escola e sociedade parecem não caminhar na mesma direção nem falar a mesma língua: a escola mostra-se previsível, normativa, priorizando uma linguagem prescritiva, atuando em via de mão única, perpetuando a transmissão de conhecimento disciplinar e fragmentado. A sociedade, ao contrário, é dinâmica, multimidiática e imprevisível, priorizando a multiplicidade e simultaneidade de linguagens, valorizando o conhecimento em rede, transdisciplinar, construído, coconstruído, desconstruído e dinamicamente reconstruído a todo momento e ao longo da vida.

Com características intrinsecamente distintas, como conceber, então, que a escola congregue indivíduos originários de uma sociedade tão estruturalmente diferente do que ela é e perpetua, e, apesar disso, tenha a missão fundamental de preparar esses indivíduos para a vida naquela sociedade? A incoerência, contudo, não se dá apenas nessa direção, pois quando a escola procura entrar em sintonia com as características e demandas sociais e, desse modo, priorizar uma nova relação com o conhecimento, é a própria sociedade que estranhamente se inquieta e, nas queixas de pais e alunos, passam a exigir práticas tradicionais, aulas e atividades repetitivas, memorização de conteúdos e professores eruditos, detentores do saber. ${ }^{3}$

A partir dessa problematização, pode-se também questionar a formação dos professores que irão atuar ou já atuam em escolas regulares. Na graduação, como alunos, questionam as incoerências teórico-metodológicas que percebem, mas, não raro, têm poucas oportunidades de atuação prática, de reflexão crítica e de reversão de qualidade da própria educação. Como profissionais em ação, com

3 Meu argumento baseia-se no que ainda acontece na maior parte das escolas. Reconheço que existem exceções e tentativas pioneiras de ruptura paradigmática, por meio das quais se busca diminuir a distância entre a realidade escolar e a social vigente. Entretanto, tais instituições estão, comparativamente, em menor proporção. 
frequência acomodam-se em um conformismo que os leva a criticar o sistema educacional; contudo, exceto no âmbito do discurso e da retórica, continuam incoerentemente reproduzindo velhas práticas, mesmo quando contam com instrumentos como o computador e a internet em suas instituições e têm acesso a programas de formação continuada, quer com recursos próprios, quer com algum tipo de incentivo ou subvenção institucional.

Levando em conta esse cenário complexo, ambíguo, contraditório e dinâmico, trago à discussão e problematizo, em primeiro lugar, concepções de formação docente para, então, buscar diretrizes para uma formação tecnológica que contemple a transição paradigmática que vivemos e habilite professores a responder, de forma adequada, às demandas sociais, cognitivas, tecnológicas e, portanto, educacionais do momento.

\section{Problematizando e refletindo sobre o conceito de formação}

O termo formação tem merecido ampla adjetivação e conotações, partindo das que, tomando por referência um menor ou maior grau de formalidade e o momento cronológico em que ocorrem, a caracterizam como:

- inicial: decorrente de processo de duração determinada, definida pela legislação vigente, incluído nos cursos de graduação e, portanto, pré-serviço;

- continuada/contínua: ${ }^{4}$ resultante de processo formal, desenvolvido por meio de cursos de curta ou longa duração, concomitante à atuação profissional, ou seja, em-serviço.

O marco distintivo dessas nomeações situa-se, portanto, na obtenção de habilitação específica que possibilite o ingresso e/ou per-

4 Neste texto, adoto as denominações continuada e contínua como sinônimas, por entender que esses adjetivos possuem a mesma conotação e ambos indicam a formação que ocorre, ao longo da vida, em cursos de curta e/ou longa duração, realizados em instituições reconhecidas. 
manência qualificados no mundo do trabalho, diferenciando, dessa forma, a preparação para a prática do exercício profissional autônomo.

Além das denominações inicial e continuada/contínua, a literatura contempla o termo autoformação, de Pineau \& Michéle (1983) e Pineau (1988). Parafraseando esses autores, Monteiro (2000, p.23) a apresenta como resultante de diferentes situações nas quais o indivíduo, pensando e gerindo a própria formação, torna-se sujeito e objeto de seu desenvolvimento intelectual, afetivo, político, histórico, ético e moral. Considerando essa conotação, Monteiro (2000) a distingue da formação continuada/contínua, pois a autoformação demanda do indivíduo "a capacidade de governar por si mesmo o seu desenvolvimento pessoal e profissional” (p.23). Assim, esse termo corresponde ao "processo de tornar-se" (Freire, 1992, p.91), que se evidencia pela "prática de ver, escutar-falar, indagar-discutir e agir” (Monteiro, 2000, p.24).

Ancorado na convicção de que várias forças auxiliam a constituição do sujeito, Pineau (1988) desenvolve a teoria tripolar de formação, identificando personalização, socialização e ecologização como os três movimentos que interferem na formação do indivíduo, originando, respectivamente:

- autoformação: a ação do eu como sujeito individual e social; ou seja, a apropriação pelo indivíduo de sua própria formação, tornando-se dela objeto;

- heteroformação: a ação de indivíduos uns sobre outros, caracterizando a dimensão social da formação; ou seja, a coformação;

- ecoformação: a ação do meio ambiente sobre os indivíduos, indicando a dimensão ambiental e ecológica da formação.

Pineau \& Patrick (2005, p.131) entendem que a teoria tripolar inclui três níveis de análise e um triplo nível de consciência e percepção da realidade. Referindo-se a essa afirmação, Ardorno (1998, apud Moraes, 2007, p.24) esclarece:

O triplo nível de consciência corresponde ao que acontece em cada nível de formação explicitado, e o triplo nível de realidade inclui a per- 
cepção e compreensão de sua multidimensionalidade e multirreferencialidade.

Argumentando sobre a teoria tripolar, ou lógica ternária da formação, Pineau (2006) enfatiza que os polos se articulam nos processos formativos, assumindo importância equivalente, ainda que, em certos momentos, um possa prevalecer sobre o outro. A formação, portanto, encontra na auto, hetero e ecoformação eixos complementares que, segundo Moraes (2007, p.26), lhe garantem unidade constitutiva, revelam seu núcleo principal e fornecem a representação de sua totalidade.

Sintetizando os conceitos contidos nos três polos norteadores de processos formativos e, simultaneamente, contrastando-os, elaboro o quadro 1.

\begin{tabular}{|c|c|c|c|c|}
\hline & \multicolumn{3}{|c|}{ POLOS } \\
\hline & & $\begin{array}{c}\text { AutoformaçÃo } \\
\text { (personalização) }\end{array}$ & $\begin{array}{c}\text { HeteroformaçÃo } \\
\text { (socialização) }\end{array}$ & $\begin{array}{l}\text { Ecoformação } \\
\text { (ecologização) }\end{array}$ \\
\hline \multirow{4}{*}{ 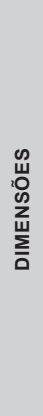 } & AÇÃo & $\begin{array}{c}\text { Individual } \\
\text { (ação do } \\
\text { indivíduo } \\
\text { sobre si mesmo) }\end{array}$ & $\begin{array}{c}\text { Social } \\
\text { (ação de indivíduos } \\
\text { uns sobre os } \\
\text { outros) }\end{array}$ & $\begin{array}{c}\text { Ambiental } \\
\text { (ação do meio } \\
\text { ambiente } \\
\text { sobre os indivíduos) }\end{array}$ \\
\hline & SUJEITO & Sujeito individual & Sujeito social & Sujeito ecológico \\
\hline & $\begin{array}{l}\text { OBJETO DA } \\
\text { FORMAÇÃO }\end{array}$ & O sujeito & A coformação & $\begin{array}{l}\text { A relação entre } \\
\text { o humano e o } \\
\text { ambiente }\end{array}$ \\
\hline & RELAÇÕES & $\begin{array}{c}\text { Internas } \\
\text { (prioritariamente) }\end{array}$ & $\begin{array}{c}\text { Externas } \\
\text { (prioritariamente) }\end{array}$ & $\begin{array}{c}\text { Ecológicas } \\
\text { (prioritariamente) }\end{array}$ \\
\hline
\end{tabular}

Quadro 1 - Concepção ternária dos processos formativos: visão contrastiva.

O quadro permite visualizar o caráter de indissolúvel continuidade que, segundo Pineau (2006), interliga os construtos nos quais se fundamenta a teoria tripolar de formação, caracterizando-os como partes essenciais de um todo sempre inconcluso, que se ar- 
ticulam e alternam continuamente, mas que podem assumir uma centralidade relativa em algum momento do processo de formação. Sob tal enfoque, interpreto que cada um dos polos apenas se define, se contextualiza e se destaca caso esteja em contraponto com os outros que, portanto, lhe conferem complementaridade e, ao mesmo tempo, identidade.

Tais considerações referem-se à formação em geral e, consequentemente, à formação tecnológica de professores, fornecendo-lhe perspectiva intrigante, na medida em que ela lança mão de ferramentas específicas - como o computador e a internet - presentes nas ambientações educacionais e, portanto, interferentes nas relações do ser humano consigo mesmo, com os outros e com o meio. Examinando essas ponderações sob a ótica do pensamento complexo (Morin, 1996a, 1996b, 2005a, 2005b), parece-me coerente conceber os processos formativos - entre eles, a formação tecnológica - como processos auto-heteroecoformativos.

Essa nomeação única, que ressalta a interconectividade e simultaneidade dos construtos que a compõem, liberta os processos formativos de uma visão reducionista e simplificadora, na medida em que destaca os sujeitos, suas individualidades, suas inter-relações e o ambiente em que se constituem, se desenvolvem e se transformam. A percepção - una e múltipla, ao mesmo tempo - evidencia a inerente complexidade que caracteriza a formação e, por isso, a relação entre suas partes (seus polos) e o todo que não se completa, gerando um processo reconhecidamente inacabável, em desenvolvimento ao longo da vida e, portanto, em permanente evolução. É com esse olhar que problematizo, reflito e procuro diretrizes para uma formação tecnológica que atenda às características do momento em que vivemos e, assim, forme e desenvolva professores capazes de responder às demandas educacionais de uma sociedade em processo de digitalização. 


\section{Refletindo e buscando diretrizes para formação tecnológica}

Entendida como uma faceta de um processo mais abrangente, a formação tecnológica não se distancia da educação de docentes, constituindo uma vertente desta, e não um caminho paralelo. Por esse motivo, quando concebemos a formação tecnológica do professor, não podemos deixar de considerar os caminhos reflexivos que ela pode percorrer e que expõem esse profissional a novas experiências de trabalho. Refletir durante a vivência dessas experiências ou sobre elas, como sugere Schön $(1983,1987,1992)$ quando destaca os construtos que compõem sua epistemologia da prática - conhecimento-na-ação, reflexão-na-ação e reflexão-sobre-a-ação -, traz a oportunidade de repensar essa prática e a possibilidade de consolidar ou transformar ações rotineiras a partir da percepção de alternativas até então inéditas (Russell \& Munby, 1991).

Os caminhos da reflexão engajam o professor em questionamentos que se intensificam gradativamente e que o conduzem a uma familiaridade com o exercício de uma postura problematizadora (Freire, 1970), que, quando conquistada, acarreta um hábito reflexivo contínuo ao longo da vida (Zeichner \& Liston, 1996; Freeman, 1992, 1996), podendo levá-lo a um estágio reflexivo ainda mais engajado: à autoconscientização ou reflexão crítica, como argumenta Kemmis (1987).

O exercício de uma postura questionadora, reflexiva e crítica esclarece o professor e o distancia de práticas repetitivas, intuitivas, voltadas para a transmissão de conteúdos, permitindo que continue indagando e não se acomode diante de dificuldades e situações problemáticas. Por isso, os caminhos da autorreflexão e/ou da reflexão compartilhada, além de empoderadores, fornecem subsídios para programas de formação docente, em um sentido amplo, e de formação tecnológica, em um âmbito mais particular, gerando questionamentos sobre quais instrumentos tecnológicos usar, quando, para que, como e por quê.

Um olhar pouco escrutinador pelas escolas que temos hoje, re- 
vela uma realidade não muito diferente da apresentada na introdução deste texto. É certo que não podemos generalizar e acreditar que um quadro monocromático e sem esperanças seja representativo da maior parte de nosso sistema educacional. No entanto, não podemos negar a existência dessa situação, principalmente na rede pública de ensino, para a qual também, ou talvez mais pontualmente, precisamos direcionar nossa atuação formadora, introduzindo questões relativas à inserção da tecnologia na educação, ao letramento digital ${ }^{5}$ e à inclusão digital de professores e alunos. Constatar essa realidade é, portanto, concordar que ela necessita de mudanças consistentes que compreendam, simultaneamente, questões de natureza pedagógica e tecnológica.

Procurando equacionar a demanda por mudanças e refletindo sobre as bases para uma reforma educacional complexa, ${ }^{6}$ elaboro uma proposta na qual seis eixos contínuos, complementares e interdependentes se articulam em uma relação não linear, não fragmentada e, dessa forma, rizomática. Nessa proposta, a perspectiva dos $6 R^{\prime} s^{7}$ (Freire, 2005a, 2005b), esses construtos essenciais têm a seguinte conotação:

5 Almeida (2005, p.174) conceitua letramento digital como "domínio e uso da tecnologia de informação e comunicação para propiciar ao cidadão a produção crítica de conhecimento, com competência para o exercício da cidadania e para inserir-se criticamente no mundo digital como leitor ativo, produtor e emissor de informações. Nessa perspectiva, o letramento digital cria condições que favorecem a inclusão crítico-social e o desenvolvimento de uma fluência tecnológica que permite conectar a educação libertadora com as demandas do mundo do trabalho".

6 Ao reconhecer a necessidade de uma reforma complexa, refiro-me a uma mudança que evoque os princípios da complexidade, como entendidos por Morin (2005a, 2005b). Ou seja, que promova um diálogo entre opostos e entre diferenças, que se liberte de uma relação necessariamente causal para assumir uma recursiva e que privilegie a conectividade sistêmica entre todo e partes, reconhecendo a não linearidade e não fragmentação de um conhecimento que se manifesta de forma transdisciplinar.

7 A perspectiva que apresento toma como ponto de partida a proposta de Fullan (1996), também discutida por Hannay \& Ross (1997). No enfoque desses autores, seriam três os construtos condutores de uma reforma no sistema educacional vigente: reculturação, reestruturação e retiming (redimensionamento do tempo). Fazendo uma releitura dessa sugestão e ampliando-a para enfatizar o desenvolvimento tecnológico de professores, chego à perspectiva aqui citada. Enfatizo que minha proposta não contradiz a visão de 
- Reculturação: visa a transformações abrangentes em relação às normas, habilidades, práticas, abordagens de ensino-aprendizagem e sistema e procedimentos avaliativos; por exemplo, possibilitando a geração de uma nova cultura escolar, diferenciada da tradicional, ainda dominante.

- Reestruturação: engloba alterações na estrutura organizacional escolar, incluindo responsabilidades e papéis formais de gestores, professores e alunos.

- Redimensionamento do tempo: propõe uma revisão do tempo utilizado na/para a aprendizagem, flexibilizando a concepção e duração de uma aula, como unidade mínima de referência (especialmente quando se trata de contextos pedagógicos semipresenciais e digitais).

- Redefinição: objetiva uma revisão conceitual consistente, abrangendo nova percepção sobre o que é, por exemplo, aula, sala de aula, interação, avaliações e programas de formação de professores.

- Relocação: considera não só a existência, mas também a pertinência de ambientes de aprendizagem fora dos limites escolares, reconhecendo que ela possa se localizar e ocorrer, também, em um contexto digital, de forma síncrona e/ou assíncrona.

- Reequipagem: propõe a instrumentalização do professor, incluindo a aprendizagem sobre como utilizar novas ferramentas e práticas, bem como novas ferramentas para novas práticas.

Uma reflexão sobre essa proposta e seus elementos-chave evidencia seu potencial para responder às demandas de nosso sistema educacional, especialmente se levarmos em conta o evidente distanciamento entre escola e sociedade, como destacado na introdução deste artigo. Além disso, ela procura enfatizar os eixos que se direcionam, essencialmente, às questões instrumental e tecnoló-

Fullan; amplia-a, contudo, para que certos aspectos e nuanças mais específicas, que interconectem educação e tecnologia, possam estar contemplados. 
gica, sem deixar de focalizar aspectos relativos a letramento e inclusão digitais, mesmo considerando que esses construtos compartilham razoável proximidade conceitual.

\section{Problematizando, refletindo e buscando...}

Retomando a argumentação apresentada e sobretudo a proposta de que processos formativos podem ser concebidos como processos auto-heteroecoformadores, posso sintetizar minha visão sobre formação tecnológica da seguinte maneira:

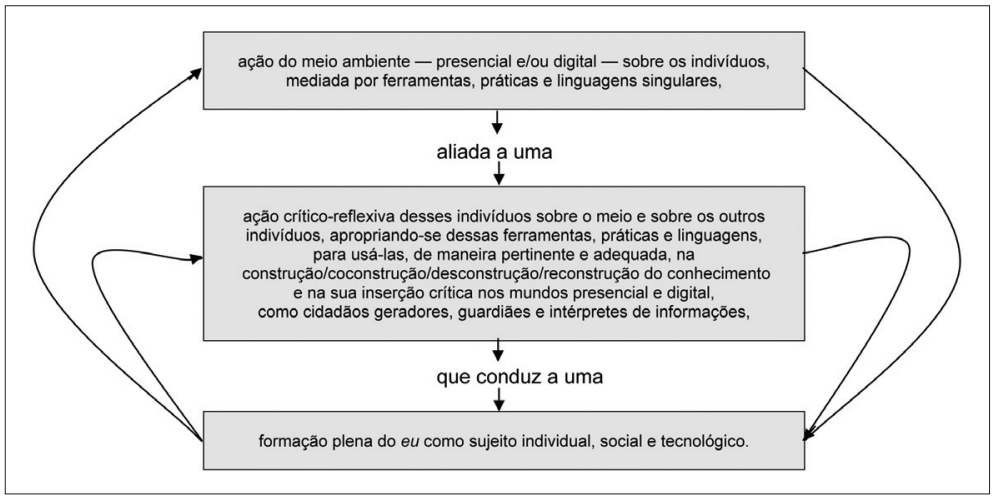

Figura 1 - Formação tecnológica como processo auto-heteroecoformador.

Partindo dessa percepção, reculturação, reestruturação, redimensionamento de tempo, redefinição, relocação e reequipagem (Freire, 2005a, 2005b) tornam-se construtos que, equacionados articuladamente, podem desencadear a auto-heteroecoformação docente, permitindo que a apropriação de ferramentas, práticas e linguagens conduza professores e formadores a uma ação progressivamente crítico-reflexiva que, por sua vez, repercute sobre o meio e sobre eles próprios, como indivíduo e grupo, gerando novas ações crítico-reflexivas, imprescindíveis para a formação do professor como cidadão social e tecnológico, inserido - e agente da inserção de seus alunos - em uma sociedade em processo de digitalização. 


\section{Bibliografia}

ALMEIDA, M. E. B. Letramento digital e hipertexto: contribuições à educação. In: PELLANDA, N. M. C.; SCHLÜNZEN, E. T. M.; SCHLÜZEN JUNIOR, K. (Org.). Inclusão digital: tecendo redes afetivas/cognitivas. Rio de Janeiro: DP\&A, 2005.

ARDORNO, J. Abordagem multirreferencial das situações educativas e formativas. In: BARBOSA, J. G. (Org.). Multirreferencialidade nas ciências e na educação. São Carlos: EdUFSCAR, 1998.

DELEUZE, G.; GUATARI, F. L’Anti-Edipe. Paris: Minuit, 1972. Mille plateaux. Paris: Minuit, 1980.

DEMO, P. Complexidade e aprendizagem: a dinâmica não linear do conhecimento. São Paulo: Atlas, 2002.

FREEMAN, D. Collaboration: constructing shared understandings in a second language classroom. In: NUNAN, D. (Org.). Collaborative language learning and teaching. Cambridge: Cambridge University Press, 1992.

Renaming experience/reconstructing practice: developing new understanding of teaching. In: FREEMAN, D.; RICHARDS, J. (Org.). Teacher learning in language teaching. Cambridge: Cambridge University Press, 1996.

FREIRE, M. M. Language teachers and computers in educational settings: the 6R's perspective. Trabalho apresentado em The CETall Symposium - AILA 2005. Madison: 2005a.

. A formação tecnológica de professores de idiomas sob um enfoque hermenêutico-fenomenológico. Projeto de pesquisa, linha de pesquisa linguagem, tecnologia e educação. Programa de Estudos Pós-Graduados em Linguística Aplicada e Estudos da Linguagel LAEL-PUC-SP, 2005b.

. A formação de professores em uma sociedade em processo de digitalização. Trabalho apresentado na Mesa Redonda "Ensino de Línguas e Tecnologia”, no VII CELSUL. Universidade Católica de Pelotas, 2006.

. Computers as pedagogical tools in the teaching and learning of English. Palestra proferida na Opening Doors: 1․ Semana de 
Estudos da Língua Inglesa. Pontifícia Universidade Católica de São Paulo, 2007a.

- A formação tecnológica de professores sob o enfoque de uma nova perspectiva. Palestra de encerramento da XXI Spring Conference. Associação dos Professores de Língua Inglesa do Estado de São Paulo (Apliesp). Universidade Presbiteriana Mackenzie, $2007 \mathrm{~b}$.

. Professores, alunos e computadores: mediadores na construção de conhecimento. Palestra proferida no curso "Especialização na área de Direitos Humanos" da Escola Superior da Procuradoria Geral do Estado. Centro de Estudos da Procuradoria Geral do Estado, 2008.

FREIRE, P. Pedagogia do oprimido. São Paulo: Paz e Terra, 1970.

. Pedagogia da esperança: um reencontro com a pedagogia do oprimido. São Paulo: Paz e Terra, 1992.

. Política e educação: ensaios. São Paulo: Cortez, 1995. (Questões da nossa época, 23).

FULLAN, M. Turning systemic thinking on its head. In: Phi Delta Kappan, p.420-3, 1996.

GIUSTA, A. S. Concepções do processo ensino/aprendizagem. In: GIUSTA, A. S.; FRANCO, I. A. (Org.). Educação a distância: uma articulação entre a teoria e a prática. Belo Horizonte: Editora PUC-Minas, 2003.

HANNAY, L. M.; ROSS, J. Initiating Secondary School Reform: the dynamic relationship between reestructuring, reculturing and retiming. Educational Administration Quarterly, 33, Supplement, 1997.

KEMMIS, S. Critical reflection. In: WIDDEEN, M. F.; ANDREWS, I. (Org.). Staff development for school improvement: a focus on the teacher. Londres: The Falmer Press, 1987.

KENSKI, V. M. O papel do professor na sociedade digital. In: CASTRO, A. D.; CARVAlHO, A. M. P. (Org.). Ensinar a ensinar: didática para a escola fundamental e média. São Paulo: Pioneira Thomson Learning, 2001.

LÉVY, P. O que é o virtual? São Paulo: Editora 34, 1996.

LOPES, R. P. Um novo professor: novas funções e novas metá- 
foras. In: ASSMANN, H. (Org.). Redes digitais e metamorfose do aprender. Rio de Janeiro: Vozes, 2005.

MONTEIRO, A. L. Autoformação para ser mais: processo de humanização e de constituição da identidade. In: SAUL, A. M. (Org.). Paulo Freire e a formação de educadores: múltiplos olhares. São Paulo: Articulação Universidade/Escola, 2000.

MORAES, M. C. A formação do educador a partir da complexidade e da transdisciplinaridade. Diálogo Educacional, n.22, p.13-38, 2007.

O paradigma educacional emergente. Campinas: Papirus, 2002.

MORIN, E. Epistemologia da complexidade. In: SCHNITMAN, D. F. (Org.). Novos paradigmas, cultura e subjetividade. Porto Alegre: Artes Médicas, 1996 a.

. O problema epistemológico da complexidade. Lisboa: Europa-América, 1996b.

. Introdução ao pensamento complexo. Porto Alegre: Sulina, 2005a.

A cabeça bem feita: repensar a reforma, reformar o pensamento. Rio de Janeiro: Bertrand Brasil, 2005b.

PALLOFF, R. M.; PRATT, K. O aluno virtual: um guia para trabalhar com estudantes on-line. Trad. de Vinicius Figueira. São Paulo: Artmed, 2004.

PINEAU, G. A autoformação no decurso da vida: entre a hetero e a ecoformação. In: NÓVOA, A.; FINGER, M. (Org.). O método (auto)biográfico e a formação. Cadernos de Formação, 1. Lisboa: Ministério da Saúde-Departamento de Recursos Humanos da Saúde, 1988.

. Investigaciones transdiciplinares en formación. Anais da Jornada de Innovación Universitária: Transdisciplinaridad. Barcelona: Universidade de Barcelona, 2006.

; MICHÉLE, M. Produire sa vie: autoformation et autobiographie. Paris/Montreal: Edilig/Albert Saint-Martin, 1983.

; PATRICK, P. Trandisciplinarité et formation. Paris: L'Harmattan, 2005. 
PRIGOGINE, I. O reencantamento da natureza. In: WEBER, R. (Org.). Diálogos com cientistas e sábios: a busca da unidade perdida. São Paulo: Cultrix, 1986.

RUSSELL, T.; MUNBY, H. Reframing: the role of experience in developing teachers' professional knowledge. In: SCHÖN, D. A. (Ed.). The reflective turn: case studies in and on educational practice. Nova York: Teachers College Press, 1991.

SCHÖN, D. A. The reflective practitioner: how professionals think in action. Nova York: Basic Books, 1983.

. Educating the reflective practitioner: toward a new design for teaching and learning in the professions. San Francisco: Jossey-Bass Publishers, 1987.

. The theories of inquiry: Dewey's legacy to education. Curriculum Inquiry, v.22, n.2, p.119-39, 1992.

ZEICHNER, K. M.; LISTON, D. P. Reflecting teaching. Filadélfia: Lawrence Erlbaum Associates, 1996. 


\section{EDUCAÇÃo VIRTUAL \\ E VIRTUALIDADE DIGITAL: \\ TRABALHO PEDAGÓGICO \\ NA EDUCAÇÃO A DISTÂNCIA \\ NA IDADE MÍdIA}

Daniel Mill

Universidade Federal de São Carlos

\section{Considerações preliminares}

Sem a pretensão de esgotar o tema, este texto objetiva analisar mudanças que o fazer, os tempos e os espaços pedagógicos e a educação formal sofreram em função da virtualização da educação. Em outras palavras, pretendemos analisar a relação entre educação e virtualidade na contemporaneidade, tendo como campo de observação o processo de trabalho na educação a distância virtual. Para contextualizar essa discussão, levantaremos dois princípios básicos sobre os conceitos de educação e de virtualidade.

Sem querer ser reducionista ou simplista, partimos da premissa de que o termo educação deve ser tomado como um composto complexo e bem articulado entre ensinar e aprender. Educar envolve profunda relação de ensino e aprendizagem. Como segundo pressuposto, adotamos o termo virtual como aquilo que existe em potencial e não como o antônimo de real. Lévy (1996, p.15) discute o conceito de virtualização e afirma ser um engano a costumeira oposição entre real e virtual, especialmente quando o virtual é interpretado como ilusão. Continua ele: "a palavra virtual vem do latim medieval virtualis, derivado de virtus, força, potência. Na filosofia escolástica, é virtual o que existe em potência e não em ato". Assim 
como a árvore está virtualmente na semente, o conhecimento e a sabedoria estão virtualmente no educando. É aí que educação e virtualidade se encontram. É aí que pretendemos centrar nossa discussão. A Figura 1 representa essa metáfora da virtualidade educacional.

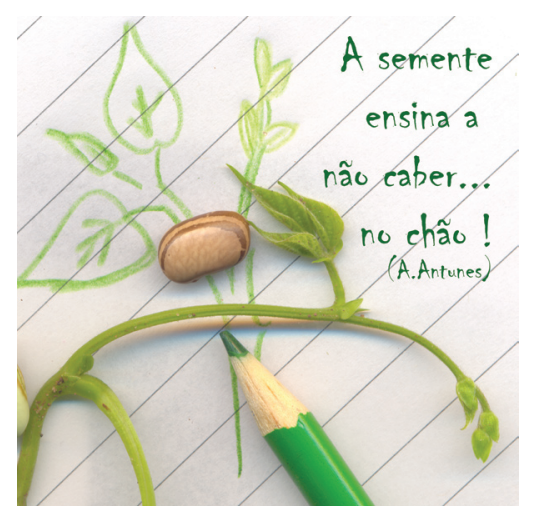

Figura 1 - Representação da relação educação e virtualidade.

\section{Sobre o termo EaD como educação a distância e não como ensino a distância}

Na literatura, na prática cotidiana dos educadores e entre os pesquisadores desta área do conhecimento, o termo EaD tem sido denominado indistintamente como educação a distância, como ensino a distância ou, ainda, como aprendizagem a distância (e-learning). A sigla EaD, entendida como Educação a Distância ou Ensino a Distância, influencia o processo de implantação e oferta de cursos a distância nas instituições de ensino.

Por um lado, essa visão pode estar mais apoiada em uma visão tradicional e ser tomada como Ensino a Distância, na qual o foco está na emissão de conteúdos e no professor. O centro do processo está no ensino e desvaloriza-se a aprendizagem (mesmo que involuntariamente). Por outro lado, quando o termo EaD é entendido como Edu- 
cação a Distância, agrega-se nele uma visão mais sociointeracionista, destacando o processo de ensino-aprendizagem, o estudante e a construção compartilhada do conhecimento, possível pelas interações dialógicas entre os diferentes participantes desse processo.

Assim, pode-se dizer que o emprego da expressão ensino a distância despreocupa-se com a aprendizagem do aluno. O professor ensina e é apoiado por tecnologias educacionais, porém, o aprendizado do estudante dependeria, em boa parte, do potencial do educando. Também, conceitualmente, a terminologia educação a distância é mais adequada por considerar o aluno como centro do processo: há docentes (professores e tutores) e tecnologias compondo o processo de ensino-aprendizagem e apoiando o estudante, mas, antes, importa se o educando está aprendendo. Obviamente, a docência (professores, tutores, projetistas, etc.) é indispensável para auxiliar o aprendizado. Por isso, é também inadequado o uso do termo aprendizagem a distância (e-learning), em que o educando é muitas vezes considerado autodidata ou capaz de aprender tudo somente com o apoio de materiais didáticos e sem o apoio dos docentes.

Adotaremos, portanto e enfim, o termo EaD como educação a distância.

\section{A educação a distância no contexto capitalista contemporâneo}

Os dados estatísticos sobre $\mathrm{EaD}$, nos últimos anos, são surpreendentes. Demonstram enorme crescimento do setor em um curto espaço de tempo. Entretanto, não acreditamos que esse salto (qualitativo, inclusive) se deva somente aos méritos da EaD ou dos profissionais que nela acreditam. Sem dúvida, as possibilidades pedagógicas desse método, marcadas pela democratização do acesso ao conhecimento, contribuíram profundamente para os avanços dos recentes números. Também o empenho dos muitos profissionais crentes nas possibilidades pedagógicas e democráticas trouxe contribuição inestimável para o desenvolvimento da EaD. Entre- 
tanto, outros aspectos empurraram os números estatísticos da educação a distância para cima: políticos, sociais e econômicos estão aí incluídos.

Somente para levantar alguns dados, o Governo Federal, em parceria com aproximadamente cinquenta instituições federais de ensino e quase trezentos municípios, planeja abrir cerca de sessenta mil novas vagas de graduação de EaD pela Universidade Aberta do Brasil (UAB). Segundo o Anuário Estatístico de EaD, tivemos, entre os anos de 2004 e 2005:

- Quase 63\% de aumento de estudantes a distância.

- Quase 31\% de aumento de instituições credenciadas para oferecer cursos de EaD.

- Abertura de cerca de cinquenta cursos de EaD em 2004 e, em 2005, outros 321 novos cursos. Nesse ano, perto de 1,3 milhão de alunos estudaram pela modalidade de EaD.

Parecem números bastante significativos do ponto de vista social - atendimento a grande número de estudantes que, se considerada apenas a democratização do acesso ao conhecimento, leva o saber a pessoas que, por motivos diversos, não podem frequentar o ensino presencial - e político - expansão do número de vagas no ensino superior, ponto nevrálgico e problemático das políticas públicas educacionais. Do ponto de vista econômico, também é fácil compreender a grande expansão da modalidade de EaD.

Em uma primeira análise, bastaria dizer que há um mito ou um equívoco de que EaD é mais barata do que educação presencial. Claro que, considerando uma educação de qualidade, a EaD não é mais barata. Então, num contexto capitalista como o brasileiro, onde estariam as motivações para investir nesse setor?

No trabalho de mestrado (Mill, 2002), dedicamos atenção especial a essa questão. Foram feitos seis estudos enfocando diferentes ângulos da $\mathrm{EaD}$, tendo por base de análise o processo de trabalho na educação a distância, a saber: 1) caracterização do processo de trabalho na EaD virtual; 2) sistemas logísticos de trabalho na EaD virtual; 3) gestão do trabalho na $\mathrm{EaD}$ virtual; 4) relações de traba- 
lho na $\mathrm{EaD}$ virtual; 5) organização do trabalho pedagógico na $\mathrm{EaD}$ virtual; e 6) relações de saber no trabalho pedagógico na EaD virtual. Dentre as conclusões desses estudos, observou-se que a expansão da EaD obedeceu aos interesses capitalistas de exploração econômica. Ela estaria sendo vista como um novo nicho de mercado, em que a exploração das mais-valias absoluta, relativa e extraordinária configurava-se plenamente possível e facilmente empregável. As transformações do padrão tecnológico de produção, associadas aos princípios de reestruturação produtiva, criaram um ambiente propício para o estímulo à EaD. Isto é, a modalidade de $\mathrm{EaD}$ adequa-se muito bem aos princípios de produção em massa do taylor-fordismo e, paradoxalmente, também atende aos pressupostos da produção flexível do toyotismo. O processo de produção flexível - que surge como solução, de modo geral, para a crise do capitalismo, isto é, aos sinais de esgotamento do fordismo entre as décadas de 1960 e 1980 - vê na EaD uma forma de entrada no tempo e no espaço de trabalho dos educadores. De alguma forma, a tradicional resistência da educação em aceitar inovações começa a ceder. Por isso, no âmbito da EaD, coexistem tanto o modelo de produção fordista quanto o pós-fordista.

Além disso, é interessante considerar que, nos últimos anos, o capitalismo conseguiu produzir um discurso tecnológico, em que se disseminou certa obrigatoriedade na adoção das tecnologias digitais. Isso estimulou não apenas o desenvolvimento de novas tecnologias de base eletrônica, informática e telecomunicacional, mas também criou certa "necessidade" de incorporação dessas tecnologias nos diversos setores da economia. $\mathrm{O}$ setor educacional não poderia ser exceção, embora tenha sido um dos últimos. Enfim, são diversos os fatores responsáveis pelo súbito crescimento da $\mathrm{EaD}$ no Brasil e no mundo, e um deles, talvez o mais forte, foi o econômico. Esse argumento sobre a $\mathrm{EaD}$ no contexto capitalista servirá de pano de fundo para nossa análise. ${ }^{1}$

1 Em relação à influência capitalista sobre o processo de trabalho na $\mathrm{EaD}$, sugerimos os estudos de Belloni (2003) e Mill (2002). 


\section{Uma breve análise do discurso tecnológico capitalista na Idade Mídia}

Em relação ao referido discurso tecnológico, vale destacar o estudo realizado por Favacho e Mill (2007), no qual consideram que a ideia do discurso tecnológico como verdade intransponível se dá a partir da reunião de diferentes interesses: educacionais, empresariais, econômicos, religiosos, etc. Para os autores, tais interesses anunciam um conjunto de prescrições que alteram as subjetividades e criam um tipo de economia e de exploração sem precedente. Uma das "funções do discurso tecnológico é que, na sociedade contemporânea, a relação de saber que engendra poder é marcada por um conturbado processo de inovações tecnológicas em curto prazo. Em decorrência dessa aceleração das inovações em curto prazo, as relações de saber tornam-se efêmeras na medida em que a crítica ao saber tecnológico é substituída pelas facilidades da técnica (inovação)".

Para Frederico Lima (2000, p.7), vivemos em uma época em que um conhecimento de dez anos atrás pode ser considerado arqueológico, tal a distância entre ele e as acelerações de mudanças em nossa sociedade. O autor acredita que a humanidade está tendo dificuldades de parar para digerir novas informações e adaptá-las à matriz de pensamento, pois "a simultaneidade dos fenômenos e a intensificação das mudanças nos colocam dentro de um vertex no qual a evolução linear se transformou em reevolução contínua" (Lima, 2000, p.11). Nesse mesmo sentido, Willians Biernazki (2000, p.47) esclarece que

o acesso instantâneo às informações e ao entretenimento é tão ubíquo que, às vezes, nos esquecemos de que esse é um fenômeno que apareceu muito repentinamente na história - é tão recente que não tivemos tempo para passar pelo processo de tentativa e erro, necessário para desenvolver instituições culturais que possam lidar adequadamente com ele. 
Vale destacar que, hoje, a sociedade tem como característica principal a intensificação do uso ou a supervalorização da informação. Considerando que a nova esfera de informação opera em um contexto global, Kumar (1997, p.22) afirma que o "homem não tem mais necessidade de buscá-la, já que ela pode ser trazida ao lar ou ao escritório". Aliás, como bem argumenta Manuel Castells (1999, p.114), o total entendimento do mundo contemporâneo, incluindo a revolução tecnológica atual, "exigiria a discussão da especificidade das novas tecnologias da informação 'vis-a-vis' seus predecessores históricos também de caráter revolucionário". ${ }^{2}$ Entretanto, "o cerne da transformação que estamos vivendo na revolução atual refere-se às tecnologias da informação, processamento e comunicação" (Castells, 1999, p.68).

Nesse sentido, Kumar (1997), fundamentando-se em Daniel Bell (1980), afirma que o que gerou essa sociedade da informação foi a convergência explosiva de computador e telecomunicações. Afirma, ainda, que essa união acabou com a antiga distinção entre processamento e disseminação de conhecimentos, da mesma forma que ocorria com mídias como a televisão. É por isso que Daniel Bell acredita que "nos transformamos em uma economia de informação" (Kumar, 1997, p.21-2). Daí porque, sendo a sociedade contemporânea sustentada por uma economia da informação, o capital tem sua forma de lucro e infraestrutura fundada na produção, no processamento e na disseminação de informações. Numa economia dessa natureza, emerge-se um "novo" elemento a ser agregado aos princípios objetivos da economia clássica, qual seja, a economia da subjetivação.

Como concluem Favacho e Mill (2007), essa economia da subjetivação também constitui uma das funções do discurso tecnológico no capitalismo. Assim, mais do que criar nos sujeitos uma pseudonecessidade de consumo de informações, a economia da subjetivação nutre-se das formas de inovações criadas pelos próprios sujeitos

2 Argumento presente numa nota de pé de página (nota 11) do livro de Castells (1999). 
frente a essa "necessidade". Eis uma função cíclica e intermitente do capital informacional. Essa economia é aquela que toma como centro um conjunto de discursos válido por todo o corpo social e retira dele todas as possibilidades objetivas e subjetivas de exploração. Associada a essa "nova" concepção de economia, de capitalismo informacional (Castells, 1999, p.55), está a primazia do acesso à informação, ao conhecimento, ao saber, combinada à facilidade de sua produção, processamento e disseminação, fruto da articulação entre tecnologias como satélites, televisão, telefone, cabo de fibra óptica e microcomputadores.

Dessa economia da subjetivação decorre outro aspecto das funções do discurso tecnológico: a unidade demográfica. A capacidade dos modernos meios de comunicação de influenciar grandes públicos cria, hoje, outra relação no interior da cultura de massa. A novidade é que esse conjunto de tecnologias (telemática) permite ao capital o acesso à unidade demográfica da sociedade (o indivíduo), o que, por sua vez, criou a possibilidade de manipulação das subjetividades.

As tecnologias digitais possibilitam a personalização de tal forma que levam Manuel Castells (2003) e Nicolas Negroponte (1995, p.158) a acreditar que os meios de comunicação de massa atingem a unidade demográfica da sociedade, composta por uma só pessoa. $\mathrm{O}$ acesso à unidade demográfica, materializado pela virtualização recente (pela internet, especificamente), apresenta-se como uma estratégia capitalista de exercer o poder, apreendendo a subjetividade na sua capilaridade, ou seja, nos aspectos mais íntimos e locais. Isso inaugura outra relação do capital com a cultura de massa. Agora temos, com frequência, um "público de massa" composto de uma "única pessoa". Eis aí uma relação paradoxal. Se, por um lado, as novas tecnologias da informação e comunicação possibilitam um processo comunicacional em massa, por outro, num tempo considerado "informacional", tudo é feito por encomenda e a informação é extremamente personalizada.

O elemento crucial desse paradoxo é que o consumo de massa não é apenas uma produção direcionada a um amplo e infinito pú- 
blico, mas atende, ao mesmo tempo, a diversos e variados públicos. Portanto, não se destina apenas a uma única e grande massa, mas às particularidades desses enormes contingentes. Basta percorrer os inúmeros sites da internet para atestar as diferentes "tribos" urbanas, consumidoras de seus produtos específicos. Atualmente, o consumidor pode montar determinado produto (como é o caso dos acessórios de automóveis) e ter com exclusividade um produto "criado" virtualmente.

Assim, a produção, o processamento e a disseminação de informação que, desde a década de 1930, ocorriam em processos comunicacionais de um-para-muitos, tornam-se agora, com a internet, uma comunicação em estrela de muitos-para-muitos. Dessa maneira, a internet propicia uma relação de poder do capital diretamente com o sujeito, em sua intimidade, e não apenas de forma coletiva, como ocorre com mídias tradicionais (televisão ou rádio, por exemplo). Obviamente, vale a advertência de que se, por um lado, o capital tem o acesso direto ao indivíduo, o contrário não se realiza necessariamente.

$\mathrm{Na}$ medida em que extrapola a simples mecanização do trabalho, como percebido até então, atingir essa unidade demográfica (acesso direto ao indivíduo) constituiu mais uma novidade no processo de internacionalização do capital. Atualmente, a novidade passa pela "mecanização da vida em geral, da esfera privada da vida social: o lazer, a cultura, a vida doméstica” (Belloni, 2001, p.54). A autora acredita que essa tecnologia midiática (a exemplo da máquina televisiva), ao ser inventada, acaba impondo-se ao homem, acorrentando-o ao lazer fácil e barato, à representação em lugar da experiência (p.58). De forma mais geral, essa ideia é também encontrada em Machado (1996).

É nesse contexto capitalista, com a subjetividade "manipulável" e com a unidade demográfica acessível, que se estabelece o processo de trabalho docente virtual, com novos espaços e tempos pedagógicos. 


\section{Espaço, tempo e tecnologia no trabalho pedagógico da Idade Mídia}

O estágio de desenvolvimento tecnológico que estamos experimentando atualmente trouxe consigo inéditas possibilidades de comunicação ou interação entre sujeitos; isto é, trouxe-nos novas possibilidades de experimentar tempos e espaços - a experiência espaço-temporal dos homens depende do desenvolvimento tecnológico da época considerada. Isso também é verdadeiro no âmbito do trabalho e da educação. Aliás, tempos e espaços escolares constituem fatores fundamentais para a compreensão do processo e desenvolvimento do trabalho pedagógico.

A forma como tempos e espaços escolares são organizados afeta profundamente a prática pedagógica: o tempo de começar e de terminar a aula, o tempo de cada conteúdo, de cada disciplina, de cada bimestre, de cada semestre, de cada ciclo, de cada ano letivo, de cada aula, do recreio, de contato com os colegas de trabalho, de relação com os alunos, de uso do quadro de giz, do livro didático, do computador, da fala, das discussões, conflitos e consensos, das reuniões, das festas, de trabalho, de lazer, de descanso. São tempos, de algum modo, interligados entre si e diretamente relacionados com a prática docente. Análise semelhante vale para os espaços escolares: os espaços da sala de aula, da sala de professores, da biblioteca, da sala de reunião, da secretaria, da direção, do pátio, dos corredores, da cantina, de trabalho e de descanso são locais físicos, socialmente organizados, para possibilitar melhores ensino e aprendizagem. De alguma forma, são tecnologias desenvolvidas para dar suporte a diferenciadas propostas pedagógicas. Reside, nesse espaço escolar, uma importância formadora. A forma como ele está organizado interna e externamente, a definição das suas unidades de funcionamento, como ele é explorado, apropriado, ocupado e definido evidenciam a história dos grupos que o conformam.

Pensando nessa relação intrínseca entre espaço-tempo e proposta pedagógica, merece atenção o questionamento: mudar de lugar os objetos e os usuários de uma sala de aula é apenas uma 
mudança na sala de aula ou nos coloca diante de outra sala de aula? O que é uma sala de aula? O que é uma escola? No contexto da sociedade informacional, em um ambiente virtual de aprendizagem, na EaD pela internet, o que pode ser concebido como uma sala de aula ou como escola?

Como afirmam Dussel e Caruso (2003), a história da sala de aula manteve-se quase imutável nos últimos cinco séculos (ou mais), porém podem ser percebidas, desde meados do século XX, bruscas mudanças nessa história em função da instalação da técnica e da tecnologia no contexto escolar. Grosso modo, inferimos que a sala de aula virtual - o espaço de trabalho do docente da EaD virtual - é apenas uma configuração distinta da tradicional. Reconfigurados dessa forma, os novos espaços e tempos ajustam-se às novas necessidades e/ou ao estágio de desenvolvimento tecnológico. Tais necessidades e desenvolvimento podem ser vistos da perspectiva de uma evolução da civilização humana ou da nova fase de acumulação capitalista. O quadro pode ser completado com as possibilidades de experimentação do tempo da atualidade, especialmente aquelas ligadas à flexibilização de "tudo": uma sala de aula em que o arranjo "material" não obedece ao espaço físico ou geográfico, uma sala de aula que está em todo lugar e a qualquer momento... Afinal, a flexibilidade temporal possibilitou a ampliação do espaço, ou melhor, ciberespaço, quase celestial: onipresença, onisciência e onipotência. Como diria David Harvey (2001, p.184), vivemos nessas novas rodadas e formas de configuração temporal e espacial que o atual regime de acumulação encontrou elementos de ingresso no contexto educacional, com estabilidade de médio prazo. Acabamos de presenciar, pois, o nascimento de uma sala de aula muito engraçada!

\section{Sobre a Idade Mídia ou trabalho docente na economia da informação}

As tecnologias de informação e comunicação - típicas do nosso tempo e mais presentes no processo de trabalho a distância - inter- 
ferem na experiência com o espaço-tempo de determinado grupo social. Para Thompson (1998), as novas tecnologias ${ }^{3}$ passam a condicionar o sentido do tempo, e suas formas de medição tornam-se meios de exploração do trabalho. Isso nos leva ao fato de que o trabalhador docente a distância, tendo suas atividades mediadas por tecnologias ${ }^{4}$ digitais, poderá estabelecer relações diferenciadas com o tempo e com o espaço em comparação ao docente presencial, implicando necessariamente outro patamar de exploração da mais- valia ${ }^{5}$ pelo capital no âmbito educacional.

Nesse contexto, apresentam-se questionamentos como: que transformações podem ser observadas no trabalho do educador quando os processos pedagógicos são estabelecidos por meio de tecnologias virtuais? Como as mudanças nos tempos e espaços introduzidos pelos processos pedagógicos virtuais podem influenciar o trabalho docente? São implicações de que natureza?

Pelos estudos de Mill (2006), o processo de trabalho na EaD estabelece novos tempos e espaços para os trabalhadores da educação, e esse redimensionamento espaço-temporal afeta a prática pedagógica e o conhecimentos dos educadores. Por isso, as novas formas de experimentar o tempo e o espaço da Idade Mídia, no âmbito do trabalho, se dão a partir de processos de trabalho intensificados e relações de trabalho precárias.

A essa era que estamos presenciando denominamos de Idade Mídia. Era em que o capital faz uso das tecnologias de informação e comunicação, de todas as técnicas e tecnologias que estruturam as

3 O termo novas tecnologias foi utilizado por muitos autores no lugar de tecnologias de informação e comunicação (TIC). Por não considerá-las atuais, utilizaremos a abreviação TIC ou, ainda, telemática. Telemática é um termo utilizado para designar a fusão entre as tecnologias de telecomunicação e as de informática. No centro dessas tecnologias telemáticas está a internet.

4 O conceito de tecnologia aqui adotado tem por base os estudos realizados por Bertoldo (2004) e Vieira-Pinto (2005).

5 Para Marx (1967, p.35), todo capitalista visa a uma dupla finalidade: produzir valor de uso com valor de troca e produzir lucro: "Ele quer produzir não somente um valor de uso, mas um valor, e não somente valor, mas também mais-valia”. 
novas redes comunicacionais, para colonizar os indivíduos em si, estando interessados nisso ou não. Essas técnicas e tecnologias possibilitam, agora, novas formas de controle e coesão social cada vez mais eficazes, uma vez que elas são também mais agradáveis. Nessa nova era, o capitalismo não se limita, ironicamente, a atingir todas as pessoas de uma vez. Agora não é a comunicação de massa que está no centro das atenções, pois esta não considera o que pensa e sente cada sujeito que a compõe. A telemática trouxe a possibilidade de capilarizar a sociedade e colonizar a subjetividade de cada um dos seus membros. A era de convergência midiática, configurada sob uma nova forma de manipulação capitalista, é mais perversa, apesar de ser menos agressiva aos indivíduos (Mill, 2006).

\section{Sobre espaço e tempo de trabalho na educação virtual: redimensionamentos visíveis}

Há que se questionar a própria natureza do ensino-aprendizagem: O que é uma aula presencial? O que é uma "aula" a distância? Consideramos que alguns aspectos observáveis nas aulas presenciais não se apresentam nas "aulas" da educação a distância. A linguagem e as tecnologias utilizadas, as estratégias docentes de sedução e motivação (ou de persuasão), a interatividade, a relação com o saber, entre outros, são algumas diferenças.

A linguagem da aula presencial, por exemplo, traz consigo implicações sobre o trabalho docente. Esse tipo de aula está situado no tempo e no espaço de forma síncrona, entre alunos e professores. Por fazer uso basicamente da linguagem oral com o apoio da linguagem escrita, os riscos de mal-entendidos são radicalmente menores no ensino presencial, se comparado com o ensino a distância. Atualmente, a educação a distância baseia-se sobretudo na mídia impressa e/ou digital. Por isso, fundamenta-se, na maioria das vezes, na linguagem escrita, trazendo diferenciações na natureza do ensinar-aprender. Como observa Lévy (1993, p.88), a comunicação baseada na escrita é uma comunicação diferida. 
A escrita, ao intercalar um intervalo de tempo entre a emissão e a recepção da mensagem, instaura a comunicação diferida, com todos os riscos de mal-entendidos, de perdas e de erros que isso implica.

Muitas das tentativas de superação da má-fama que acompanhou a educação a distância até os anos 1990, ativeram-se na aproximação dos ambientes das duas modalidades. Nessa fase, o vídeo e a imagem funcionavam, basicamente, como complemento ao texto impresso, visando à substituição da comunicação do corpo e dos gestos. Com a mídia digital, muitos pontos críticos foram superados, mas ainda é comum observar que a lógica de melhoria da educação a distância tem como modelo a educação presencial. Não concordamos com isso, mas essa é outra discussão. O que nos interessa aqui é demonstrar que a natureza das aulas presenciais e a distância difere-se por meio da linguagem utilizada.

Do mesmo modo, as tecnologias influenciam a natureza da aula. Uma "aula" a distância faz uso de tecnologias diversas e bem mais complexas que aquelas das aulas presenciais. Considerando que essa mediação tecnológica influencia diretamente a prática de ensino e a prática de aprendizagem, é possível observar mudanças profundas na própria relação social na "sala de aula". O tecido social da sala de aula sofre uma metamorfose proporcional ao nível de mediação tecnológica a que está submetido. A natureza da aula muda porque a própria sala de aula muda; ou melhor, no caso da educação a distância virtual, a sala de aula não sofre uma simples mudança, pois ela deixa de existir: o que existe na educação a distância virtual é a possibilidade da sala de aula e não ela em si. Isso tem relações diretas com os aspectos psicológicos do educador e do educando. Segundo Derrick de Kerckhove (1997, p.275),

como [as tecnologias] mudam relações no tecido social, [elas] reestruturam ou modificam também aspectos psicológicos, especialmente aqueles que dependem da interação entre a linguagem e o organismo humano ou entre a mente e a máquina. 
Acreditamos que essas implicações pedagógicas de aspectos - a linguagem e a mediação tecnológica sobre a natureza da aula em si - geram influências diretas também sobre as competências requeridas do educador e, por conseguinte, sobre a formação desse profissional. Sendo o ensino-aprendizagem da educação a distância de uma natureza diferenciada em relação ao presencial, outras competências passam a compor o rol de saberes docentes. Sem essas novas competências, a aula, ou melhor, o processo de ensino e aprendizagem não seria efetivo.

Como destacamos anteriormente, são incipientes as poucas oportunidades de formação de educadores para essa modalidade de ensino. Queremos agora reforçar o que já mencionamos indiretamente: por haver demanda de educadores para a educação a distância, mesmo sem haver oferta de cursos para formação específica para essa atividade, os educadores estão buscando desenvolver as competências necessárias à educação a distância pelo método da tentativa e erro/acerto, ou seja, pela "formação em serviço" ou "aprender fazendo". Acreditamos que se trata de uma estratégia paliativa e inadequada, a julgar pela importância e atenção que as atividades educacionais merecem. A essência da formação em serviço pressupõe um momento de reflexão do trabalhador sobre sua prática a partir das teorias científicas da área, quando ele buscar novos significados para suas ações. Portanto, formação em serviço pressupõe uma formação acadêmica anterior ou paralela à prática cotidiana. Do contrário, estaríamos desmerecendo todo o conhecimento científico acumulado ao longo da história. Por não pressupor uma formação acadêmica, parece-nos equivocado concordar com a formação do "aprender fazendo" da forma como vem acontecendo na educação a distância brasileira.

$\mathrm{Na}$ verdade, é preciso destacar que a formação de educadores em educação a distância aparece como fator de extrema importância no que tange à qualidade do ensino e, portanto, não deveria ser tomada como idêntica à formação do educador da educação presencial. Mariana Maggio (2001, p.106) parece concordar com isso quando afirma que 
o tutor pode mudar o sentido da proposta pedagógica pela qual foram concebidos um projeto, um programa ou os materiais de ensino. É necessário reconhecer que sua intervenção pode melhorar a proposta. $\mathrm{Na}$ realidade, em todos os casos, os tutores deveriam ter uma formação que lhes permitisse primeiro entender, e depois melhorar, enriquecer, aprofundar a proposta pedagógica oferecida pelos materiais de ensino no âmbito de um determinado projeto.

Por fim, vale questionar se nossos educadores da educação a distância, estando na condição de "aprendizes", estão aptos a entender e enriquecer a proposta pedagógica de algum projeto de curso em que atuam. Como afirma Lévy (1999, p.171), em "novos campus virtuais", os professores e os estudantes partilham os recursos materiais e informacionais de que dispõem. Os professores aprendem ao mesmo tempo que os estudantes e atualizam continuamente tanto seus saberes "disciplinares" como suas competências pedagógicas.

Isso nos leva a retomar Manuel Castells (2003, p.211) quando afirma que a internet e a tecnologia educacional em geral só são vantajosas quando os professores se mostram preparados. Sob esse aspecto, geralmente há uma demora considerável entre o investimento em tecnologia por um lado, e o investimento na formação de educadores por outro. É importante destacar a discrepância existente entre o grande e súbito interesse pela educação a distância na última década e a pequena preocupação com a formação de educadores para atuar nessa modalidade de ensino. Indiretamente, tentamos salientar a estreita relação entre essa adequada formação acadêmica e a qualidade dos cursos oferecidos.

\section{Sobre letramento digital: desafios para educadores na virtualidade da Idade Mídia}

Sendo a escola a principal agência de letramento, parece claro que ela seja também uma instância de busca de conscientização das necessidades específicas do letramento tecnológico (digital). 
Nesse contexto que vem se configurando nos últimos anos, a educação, de um modo geral, e a escola, mais especificamente, estão sendo convidadas a repensar suas propostas curriculares. Práticas pedagógicas diferenciadas estão sendo exigidas dos educadores atualmente. A associação entre as áreas educacional e tecnológica tornou-se o centro dos esforços pedagógicos para formação do cidadão. Esse foi o tema central de um estudo realizado por Mill e Jorge (2007), em que destacaram as implicações entre letramentos tradicional e digital na sociedade contemporânea. Como eixo transversal, consideraram que tanto as práticas cotidianas quanto as políticas de educação têm sido repensadas a partir das novas relações com o saber que estão sendo gestadas na sociedade contemporânea.

Se há um consenso acerca das consequências sociais do maior acesso à informação é que a educação e o aprendizado permanente tornam-se recursos essenciais para o bom desempenho no trabalho e o desenvolvimento pessoal. (Castells, 2003, p.211)

Trabalhar com a internet ou desenvolver capacidade de aprendizado numa sociedade baseada nela exige um novo tipo de educação. Como a maior parte da informação está disponível, destaca-se a habilidade de decidir o que procurar, como obter isso, como processar e utilizar as informações encontradas para a tarefa específica que provocou sua busca - esse é o cerne dos quatro pilares da educação para o século XXI, estabelecidos pela equipe de Jacques Delors (2001).

As habilidades peculiares ao letramento tradicional já não parecem suficientes para que as pessoas usufruam adequadamente do mundo atual. Fazer amplo uso das mídias digitais em favor próprio exige um letramento digital, o que implica o desenvolvimento de estruturas cognitivas bastante complexas. Do ponto de vista da inclusão, carecemos da popularização das condições de acesso e interação com as tecnologias de informação e comunicação; carecemos de amplas estratégias de inclusão digital, que incorporem a neces- 
sidade de letrar digitalmente a população ao elaborar suas políticas públicas de educação; carecemos de propostas pedagógicas que privilegiem e possibilitem o letramento digital. Nessa carência, vigora a espreita não apenas do crescimento do abismo já existente entre sujeitos letrados e pouco letrados, mas também o surgimento de outro aspecto de exclusão entre os letrados: a exclusão na inclusão; a exclusão dos letrados tradicionais das sociedades grafocêntricas digitais.

Mill e Jorge (2007) afirmam que, em tempos de cibercultura, a denominação de sociedade grafocêntrica de tipo tradicional já não dá mais conta das relações sociais estabelecidas entre as pessoas letradas. Isso constitui grande desafio para os educadores, pois não bastará apenas o uso adequado das tecnologias da informação e da comunicação. Na verdade, será necessária mudança de mentalidade dos educadores e de todos os envolvidos nos processos de ensino-aprendizagem, incluindo gestores e alunos.

Como manter as práticas pedagógicas atualizadas com esses novos processos [da cibercultura] de transação do conhecimento? Não se trata aqui de usar as tecnologias a qualquer custo, mas sim de acompanhar consciente e deliberadamente uma mudança de civilização que questiona profundamente as formas institucionais, as mentalidades e a cultura dos sistemas educacionais tradicionais e, sobretudo, os papéis de professor e de aluno. (Lévy, 1999, p.172)

Essa nova lógica de ensino-aprendizagem requerida pela era da informação contrasta com a carência de formação de profissionais para desenvolver atividades com o apoio das novas tecnologias. De um lado, surgem situações propícias para o desenvolvimento de outra pedagogia (investimento em equipamentos e mudança de mentalidade em relação ao uso de novas tecnologias) e, de outro, as condições de trabalho dos professores não se apresentam como adequadas para desenvolver tal pedagogia.

Por motivos facilmente explicáveis, a escola, como principal agência de letramento, ainda parece desconhecer sua importância 
nesse processo. Não acreditamos que a maioria dos (atuais e futuros) educadores esteja em condições de perceber as demandas dos letrados (tradicional e digitalmente) e as dificuldades dos pouco letrados coexistindo na mesma, porém desigual, sociedade. A maioria dos educadores ainda não tem consciência das necessidades especiais que possuem os excluídos das práticas de letramento tradicional. Menos consciência ainda parece ter em relação aos excluídos das práticas de letramento digital. Trata-se de uma situação bastante grave se consideradas as transformações sofridas pelo processo de ensino-aprendizagem com o desenvolvimento já atingido pelas tecnologias da informação e comunicação. Certamente, a relação com o conhecimento em tempos de cibercultura tem sofrido mudanças drásticas, trazendo implicações diretas sobre o processo educacional.

O saber-fluxo, o trabalho-transação de conhecimentos, as novas tecnologias da inteligência individual e coletiva mudam profundamente os dados do problema da educação e da formação. [...] Mas o essencial se encontra em um novo estilo de pedagogia, que favorece ao mesmo tempo as aprendizagens personalizadas e a aprendizagem coletiva em rede. Nesse contexto, o professor é incentivado a tornar-se um animador da inteligência coletiva de seus grupos de alunos em vez de um fornecedor direto de conhecimentos. (Lévy, 1999, p.158)

Enfim, parecem ser muitos os desafios para aqueles que são comprometidos com a educação. Em relação às tecnologias digitais, resumimos nosso desejo com a seguinte afirmação: "permitir que os seres humanos conjuguem suas imaginações e inteligências a serviço do desenvolvimento e da emancipação das pessoas é o melhor uso possível das tecnologias digitais" (Lévy, 1999, p.208). Isso amenizaria em muito a diferenciação entre os que têm e os que não têm internet. Essa lacuna entre os dois grupos acrescenta uma divisão essencial às fontes já existentes de desigualdade e exclusão social, numa interação complexa que parece aumentar a disparidade entre a promessa da era da informação e sua sombria realidade 
para muitos em todo o mundo (Castells, 2003, p.203). Está posto o desafio!

\section{Considerações finais sobre educação e virtualidade}

Como informado no início do texto, em momento algum houve a intenção de esgotar a discussão. Pelo contrário, esperamos tê-la alimentado, trazendo mais elementos para o debate. Estaremos mais satisfeitos se o texto tiver suscitado mais dúvidas que respostas. Trata-se de um tema ainda carente de estudos, embora se estabeleça em campo fértil e rico. Mais recentemente, o trabalho docente virtual tem sido preocupação de pesquisadores, sindicatos e instâncias governamentais. Este texto tentou mostrar alguns dos pontos centrais da relação entre educação, virtualidade e trabalhadores da Idade Mídia. A educação a distância (EaD) concentra todos esses pontos no seu bojo e, por isso, constitui um lócus importante para estudos dessa natureza.

A educação a distância teve um crescimento vertiginoso nos últimos anos e, por isso, o texto apresentou a contextualização da sociedade capitalista contemporânea, na qual se dá o processo de trabalho docente em tempos virtuais. É importante perceber que o impulso que a modalidade de $\mathrm{EaD}$ teve possui como pano de fundo uma metamorfose de base capitalista que influencia a prática pedagógica cotidiana dos trabalhadores da educação. É no contexto capitalista, com a subjetividade "manipulável" e com a unidade demográfica acessível, que se estabelece o processo de trabalho docente virtual, com novos espaços e tempos pedagógicos. A produção de um discurso tecnológico - baseado em movimentos de capilarização da sociedade, de colonização da subjetividade e de busca pela unidade demográfica da sociedade - afeta diretamente o processo de trabalho docente virtual e traz consequências como a precariedade do trabalho docente e a desprofissionalização da categoria... entre outras. 
A sala de aula (muito engraçada) da Idade Mídia, caracterizada por novos tempos e espaços da educação, passa a exigir um novo profissional docente, marcadamente polidocente, um trabalhador coletivo. Enfim, a educação em tempos virtuais é mais complexa, mais viva e precisa ser pensada e feita de uma forma diferente e com uma cautela não necessária em tempos anteriores à virtualidade digital.

O estágio de desenvolvimento tecnológico que estamos vivenciando trouxe-nos novas possibilidades de experimentar tempos e espaços para a vida em geral e também para o mundo do trabalho e da educação. É preciso atentarmos para as diversas questões daí decorrentes... algumas delas apresentadas neste texto.

\section{Bibliografia}

BELL, D. The social framework of the information society. In: FORESTER, T. (Org.). The microelectronics revolution. Oxford: Blackwell, 1980.

BELlONI, M. L. O que é mídia-educação. Campinas: Autores Associados, 2001.

. Educação a distância. 3.ed. Campinas: Autores Associados, 2003

BERTOLDO, H. L. As origens do conceito de tecnologia: téchne ( $\tau \varepsilon \chi \vee \eta)$ grega e técnica renascentista. Belo Horizonte, 2004. Dissertação (mestrado em Educação Tecnológica) - Centro Federal de Educação Tecnológica de Minas Gerais (CEFET).

BIERNAZKI, W. E. Globalização da comunicação. Comunicação e educação, n.19, p.46-65, 2000.

CASTELLS, M. A galáxia da internet: reflexões sobre a internet, os negócios e a sociedade. Rio de Janeiro: Jorge Zahar, 2003.

. A sociedade em rede. 6.ed. São Paulo: Paz e Terra, 1999. (A era da informação: economia, sociedade e cultura, v.1).

DELLORS, J. Educação: um tesouro a descobrir. 6.ed. São Paulo: Cortez; Brasília: MEC/UNESCO, 2001. 
DUSSEL, I.; CARUSO, M. A invenção da sala de aula: uma genealogia das formas de ensinar. São Paulo: Moderna, 2003.

FAVACHO, A. M. P.; MILL, D. Funções do discurso tecnológico na sociedade contemporânea. Pro-Posições (Campinas), v.18, n.3 (53), p.197-214, 2007.

HARVEY, D. Condição pós-moderna. 10.ed. São Paulo: Loyola, 2001.

KERCKHOVE, D. de. A pele da cultura: uma investigação sobre a nova realidade eletrônica. Lisboa: Relógio D’Água Editores, 1997.

KUMAR, K. Da sociedade pós-industrial à pós-moderna: novas teorias sobre o mundo contemporâneo. Rio de Janeiro: Jorge Zahar, 1997.

LÉVY, P. As tecnologias da inteligência: o futuro do pensamento na era da informática. Rio de Janeiro: Editora 34, 1993.

. Cibercultura. São Paulo: Editora 34, 1999.

. O que é o virtual? São Paulo: Editora 34, 1996.

LIMA, F. O. A sociedade digital: impacto da tecnologia na sociedade, na cultura, na educação e nas organizações. Rio de Janeiro: Qualitymark, 2000.

MACHADO, A. Máquina e imaginário: o desafio das poéticas das tecnologias. São Paulo: Edusp, 1996.

MAGGIO, M. O tutor na educação a distância. In: LITWIN, E. (Org.). Educação a distância: temas para o debate de uma nova agenda educativa. Porto Alegre: Artmed, 2001.

MARX, K. O Capital. Edição resumida por Julian Borchardt. Rio de Janeiro: Jorge Zahar, 1967.

MILL, D. Educação a distância e trabalho docente virtual: sobre tecnologia, espaços, tempos, coletividade e relações sociais de sexo na Idade Mídia. Belo Horizonte, 2006. Tese (doutorado)FAE/UFMG.

Estudos sobre processos de trabalho em educação a distância mediada por tecnologias da informação e da comunicação. Belo Horizonte, 2002. Dissertação (mestrado) - FAE/UFMG.

; JORGE, G. Letramento, cognição e processos de inclusão 
em sociedades digitais. Vertentes (São João Del Rei), ed. especial, p.7-21, 2007.

NEGROPONTE, N. A vida digital. São Paulo: Companhia das Letras, 1995.

THOMPSON, E. P. Tempo, disciplina de trabalho e o capitalismo industrial. In: . Costumes em comum. São Paulo: Companhia das Letras, 1998, p.267-304.

VIEIRA-PINTO, A. O conceito de tecnologia, v.2. Rio de Janeiro: Contraponto, 2005. 



\title{
O MÉTIER DO PROFESSOR EM CONTEXTO DIGITAL
}

\author{
Anise A. G. D'Orange Ferreira \\ UNESP, FCL - Araraquara
}

Todos, aparentemente, sabemos o que faz um professor. Ora, o professor apresenta aulas ou explica matéria, talvez tenha de preparar as lições e, no final, dá provas e as corrige. Isso significa ensinar. Seu objetivo é fazer o aluno aprender. É frequente esquecer-se do lado ou valor profissional do trabalhador do ensino, isto é, que ser professor é executar um trabalho. Quem não ouviu os famosos clichês "fulano é professor e também trabalha" ou, então, "quem sabe faz, quem não sabe, ensina”? A julgar por essas ideias, ser professor não é trabalho e, na melhor das hipóteses, é estar em uma missão, ter uma vocação e fazer uma doação de sua própria vida. Não se pode negar que haja similaridades entre alguns professores e missionários em suas preocupações de transformação social, mas devemos lembrar que um missionário nem sempre é remunerado em suas missões, pois sua motivação é religiosa. Em uma missão ele será tanto melhor quanto seus alunos se mostrarem mais bem instruídos.

Por que falar em métier se todos sabemos qual é o papel do professor? $\mathrm{O}$ emprego do termo francês é uma referência à abordagem da ergonomia da atividade, adotada na visão integradora do trabalho do professor Machado (2004), mostrada na publicação $O$ ensino como trabalho, que se ancora na perspectiva do grupo Ergape (Ergonomie de l'activité des professionnels de l'Éducation) (Saujat, 
2004, Amigues, 2004) e da Clínica da Atividade (CLOT, 2006), seguindo a análise do interacionismo sociodiscursivo (ISD) (Bronckart \& Machado, 2004, Bronckart, 2008). O que acrescenta à visão desse profissional olhar para a atividade do professor à luz de tal abordagem?

Saujat (2004), em um panorama do trabalho do professor nas pesquisas em educação feitas nos Estados Unidos, observa que o docente, apesar de ser objeto de análise com uma extensa tradição e aparecer de diversas formas, ainda não é estudado como trabalhador ou visto de um ponto de vista ergonômico. Na pesquisa da didática francesa, por exemplo, o autor aponta uma recensão em que os trabalhos centrados no professor resumem-se a $5 \%$. As demais pesquisas estudam os objetos do saber e o desenvolvimento das competências de linguagem dos alunos, e não a atividade dos professores. No quadro analítico do trabalho do professor em que se ancora Machado (2004), ou seja, no ISD (Bronckart, 2007), a linguagem, grosso modo, é vista como a forma e o principal meio de constituição, transmissão, desenvolvimento e aprendizagem em uma sociedade. Trata-se de uma abordagem que procura explicitar os pressupostos que permeiam as relações entre atividade, agir e linguagem. Explicitadas essas relações, o ISD oferece uma proposta de análise pela e na linguagem que é produzida por um sujeito em um determinado contexto ou situação de produção. Nos textos relativos ao trabalho do professor, então, procuram-se as interpretações das figuras de ação ou do agir docente. Um dos textos analisados nessa abordagem é prefigurativo do agir, normativo, aquele em que se pressupõe a disseminação de parâmetros das ações profissionais.

Minha proposta, aqui, contudo, não é fazer análise de um texto ou discurso produzido sobre o trabalho do professor on-line, mas produzir um texto baseado em minha própria experiência (Collins, Ferreira et. al., 2003; Ferreira, 2004, 2005a, 2005b, 2007) e em estudos de outros profissionais, com o intuito de delinear o objeto conflitante e peculiar do qual estou me propondo a falar.

O que é, portanto, o trabalho de ensino de um professor que 
atua no contexto digital, já que a disseminação da cultura tecnológica na cultura escolar vem ocorrendo desde os anos 1980 no Brasil, como nos informa Almeida (2008), com os problemas da formação docente caminhando desde então (Valente \& Almeida, 1997) e, na esfera da $\mathrm{EaD}$, diante de diversas recomendações pedagógicas para a melhora da qualidade no desenho instrucional (Reeves \& Reeves, 1997, Anderson, 2004, Siragusa, Dixon \& Dixon, 2007)? Iniciei meu texto partindo do pressuposto de que o ensino como trabalho pode ir muito além do compromisso necessário de aprendizagem do aluno; inclui pensar nas questões ligadas à organização do trabalho e forma de produção; como relembra Abreu-Tardelli (2004), questões que dizem respeito ao local onde o profissional atua, à relação contratual entre empregador e empregado, à duração do trabalho, à utilização de novas tecnologias, entre outras coisas.

Em sua pesquisa sobre as prescrições da legislação e a atuação do professor em EaD, Abreu-Tardelli (2004), ancorando-se no ISD e analisando textos de prefiguração do agir do docente, busca as formas de agir no discurso. No decreto analisado (n.2.494, de 10/2/1998) que regulamenta o artigo 80 da Lei 9394/96 (LDB), cuja definição de "educação a distância" coloco a seguir, os protagonistas são inanimados: cursos, programas de mestrado e doutorado, avaliação, etc., colocados em "exigências, procedimentos, critérios e indicadores de qualidade definidos em ato próprio" (p.189); a autora mostra que o presidente é apresentado como ator do agir prescritivo e o professor não aparece sequer como agente no agir decorrente (por exemplo: "os cursos [...] serão organizados em regime especial”). "O professor não é posto, assim, como participante ativo, consciente e responsável por uma série de atividades previstas ” (p.188). Eis a definição de EaD no decreto de 1998:

Art. 1ํ - Educação a distância é uma forma de ensino que possibilita a autoaprendizagem, com a mediação de recursos didáticos sistematicamente organizados, apresentados em diferentes suportes de informação, utilizados isoladamente ou combinados, e veiculados pelos diversos meios de comunicação. (p.1) 
Durante algum tempo, permaneceu a definição de EaD do decreto analisado. Posteriormente, surgiu uma redefinição, apresentada no texto do Decreto n.5.622, de 19/12/2005, reproduzida abaixo:

Art. 1ํ- Para os fins deste Decreto, caracteriza-se a educação a distância como modalidade educacional na qual a mediação didático-pedagógica nos processos de ensino e aprendizagem ocorre com a utilização de meios e tecnologias de informação e comunicação, com estudantes e professores desenvolvendo atividades educativas em lugares ou tempos diversos. (p.1)

No novo decreto, adotando os critérios analíticos de Abreu- Tardelli, observo que além do artigo primeiro (em que o docente é sujeito ativo no desenvolvimento de atividades educativas), o professor é poucas vezes nomeado, mas aparece como protagonista e o papel que lhe é atribuído é o de beneficiário, ou seja, aquele que é apresentado no texto como um destinatário animado de um processo dinâmico ("atendido pelo suporte e instalações", Brasil, 2005, p.4) e também é passível de seleção e de capacitação (ibidem, p.8). Está, ainda, na expressão "corpo docente" (ibidem, p. 4 e 7), como sujeito coletivo, dotado de certos atributos ou qualidades, titulado e "preferencialmente com formação para o trabalho com educação a distância" (ibidem, p.4).

Isso é o que reporta um documento oficial de prefiguração do agir. Como lembra Anderson (2004), o ensino e a aprendizagem pelo computador apresentam muitas coisas em comum com outros contextos de aprendizagem, uma vez que se levantam as necessidades dos alunos, o conteúdo é negociado ou prescrito, as atividades devem ser elaboradas e a aprendizagem, avaliada. Mas o meio traz peculiaridades fundamentais: a mudança do tempo e do local da interação, a habilidade de oferecer um conteúdo em formatos diferentes e a amplitude da internet, que dá acesso a recursos antes inimagináveis. O pote de ouro no fim do arco-íris é o que se propaga do ponto de vista de uma dimensão didática - os benefícios e as 
maravilhas da tecnologia moderna; um novo paradigma educacional e assim por diante. Do ponto de vista do gerenciamento do trabalho, o contexto é um fator complicador da ação e da linguagem se pensarmos nos pressupostos do quadro do ISD.

O artigo primeiro do decreto governamental (Brasil, 2005, p.1) assume que a $\mathrm{EaD}$ tem modos de organização peculiares quanto à metodologia, gestão e avaliação. Mas no parágrafo primeiro não especifica o que é peculiar, e sim aquilo que não deve ser inerente e ser igual ao presencial, como mostra a passagem abaixo, depois da qual segue uma lista de exigências referentes à avaliação, defesa de trabalho, estágio e laboratório:

$\S 1^{\circ}$ - A educação a distância organiza-se segundo metodologia, gestão e avaliação peculiares, para as quais deverá estar prevista a obrigatoriedade de momentos presenciais para...

O documento tem como objetivo a regularização e credenciamento de cursos, porém não encontramos nada sobre a mediação, gestão e avaliação peculiares. O plano pedagógico deve ser descrito pela instituição proponente. De qualquer forma, o que se apresenta para os cursos a distância são alguns critérios de cursos presenciais. Ora, se a EaD organiza-se segundo metodologia, gestão e avaliação próprias, como prevê o $§ 1^{\circ}$ do artigo 1ํㅡ, transcrito abaixo, como se podem estabelecer critérios da modalidade presencial para regular um programa a distância?

$\S 10-$ Os cursos e programas a distância deverão ser projetados com a mesma duração definida para os respectivos cursos na modalidade presencial. (p.2)

Vou tentar demonstrar aqui que algumas especificidades da EaD têm impacto direto na gestão que é regulada por parâmetros presenciais, no que concerne especialmente à hora-aula e carga horária, à elaboração de materiais, aos modos de interação e linguagem e à relação com os pares. Podemos dizer que certas características da EaD 
são conflitantes com a dimensão e a temporalidade atribuídas e exigidas para o curso presencial.

No âmbito presencial, as ações do professor em aula são reguladas por hora-aula - unidade de trabalho do docente - em regência de disciplinas da sua especialidade. Certo número de horas-aula constitui a carga horária, que define a duração do curso, de uma disciplina conferindo-lhe créditos. A carga horária também define o tempo de trabalho do professor. Essa hora-aula baseia-se na sincronia e na "sintopia" entre professores e alunos em horários e locais predeterminados. Se deixo de ter tais parâmetros, como posso quantificar hora-aula? Como redefinir a experiência concreta da aula na EaD? Essa questão nos leva ao modo de interação e de linguagem.

A comunicação oral e síncrona é a mais rápida nas tomadas de decisão e nos esclarecimentos de sentido. Ela é a base tradicional de aulas palestras e de aulas presenciais que empregam diversas metodologias. A leitura e escrita são inseridas no contexto e adicionadas como apoio durante, ou após, as aulas. Nas aulas a distância mediadas por computador, a comunicação síncrona e realizada com voz está restrita por diferentes capacidades de hardware, software e rede entre os usuários e servidores ou provedores de serviço e acesso. Assim, é habitual a comunicação síncrona realizada pela escrita, o conhecido chat. É uma comunicação mais trabalhosa para se alcançar os objetivos, pois requer rapidez e habilidade na digitação e leitura de conversas truncadas, com concorrência de turnos e tópicos por parte dos interlocutores; requer paciência e tolerância dos participantes no âmbito de uma comunicação intencional e parcialmente planejada. Se, por um lado, temos a vantagem do registro para acesso posterior à comunicação, contendo os tópicos para serem revistos pelos alunos e professores, o tempo e o esforço gastos na atenção ao discurso são maiores. É possível estabelecer uma analogia entre a aula presencial e a aula síncrona a distância, aceitando-se a permanência de um conceito de hora-aula, porém lembrando que há um custo temporal e esforço maior do que a aula oral; para nós, ainda não é natural estabelecer longas conversações didáticas 
usando a escrita. A dimensão desse tipo de aula em horas precisaria ser repensada. Em Abreu-Tardelli (2006), podemos encontrar uma análise sobre o trabalho do professor em aula, nos moldes do quadro do ISD, que dá suporte a essa posição.

Apesar da viabilidade do chat, meio de comunicação síncrona, uma das vantagens da internet na EaD é justamente a assincronia, ou seja, o aluno não ficar restrito aos horários predeterminados de aulas. Partindo do pressuposto de que grande parte dos cursos a distância visa o público da educação continuada adulta, que tem horários de trabalho, agendar as aulas a distância para uma classe excluiria muitos participantes. Dizendo de outra forma: só aqueles que podem participar do chat no domingo podem se matricular nos cursos a distância. Estamos acostumados a impor essas condições em cursos presenciais, mas a internet veio propor caminhos alternativos para as barreiras de tempo e espaço. Se um atrativo da EaD é o estudo assíncrono, retornamos à questão da unidade hora-aula para definir a atividade de aula do professor. Como definir a hora do professor tendo como referência a hora do aluno? Qual seria a hora de aula da docência assíncrona? Como registrá-la? Pelo tempo que ele gasta respondendo mensagens ou escrevendo uma instrução? Por laudas ou caracteres? E o tempo da leitura, da reflexão e da pesquisa que o professor tem de realizar para enriquecer a interação? Algumas pesquisas indicam que a comunicação em listas ou fóruns aumenta consideravelmente o fluxo da interação e a participação referente a um tópico quando se comparam a conversas síncronas em salas de aula presenciais. É claro que, tradicionalmente, estamos acostumados a ter limite temporal definido para a interação síncrona presencial; em fóruns, também podemos impor limite, mas não parece que esse limite possa ser estabelecido em unidades de horas, semanas ou número de intervenções dentro de um período; em uma semana, um fórum pode ser muito ativo. Do ponto de vista didático-pedagógico, o aumento de interação é bem-vindo e quanto mais tempo os alunos se dedicarem à disciplina, melhor. Mas, do ponto de vista do trabalho, não parece viável que toda a carga dessa interação seja atribuída a um só indivíduo, o re- 
gente de uma sala de aula. A contratação de monitores pode ser frutífera, mas também pode mascarar a desvalorização do trabalho docente qualificado e necessário.

Há uma tendência a valorizar os cursos híbridos ou a adotar o que se chama de blended learning (Ferreira, 2005b), em que as aulas presenciais são combinadas com aulas ou recursos a distância. Dessa forma, o professor mantém sua atividade síncrona nos cursos presenciais regulares e acrescenta uma atividade assíncrona (às vezes também síncrona) fora dos horários de aula. Mas, para o professor, como contar sua hora-aula no acompanhamento das discussões? Isso não é prescrito nem regulamentado pela legislação e o modelo usado no curso presencial não ajuda. A minha experiência conta com relatos informais de colegas e alunos que se sentem abusados por serem designados, obrigatoriamente, por superiores a participar de cursos na instituição. Eles aceitam, por intimidação, aumento de carga horária sem a devida remuneração, ou mesmo, sem a possibilidade de gerenciar tal condição. O que fazer então? Delegar o acompanhamento assíncrono a outros profissionais? Com quantos alunos, durante quanto tempo esse profissional poderia interagir ativamente? O professor poderia agir parcimoniosamente em seus momentos síncronos? Essa questão nos leva a uma outra que é a da elaboração dos materiais.

A preparação de aulas e materiais é uma ação prevista para um professor em qualquer contexto. $\mathrm{O}$ processo envolve pesquisa, leitura e seleção de materiais geralmente impressos, composição oral ou escrita dos conteúdos desses materiais, em torno de um objetivo, para ser apresentada oralmente, formulação oral ou impressa de instruções, requisição da atitude dos alunos ou expressão de algum tipo de reflexão ou ação sobre os materiais compostos e reunidos pelo professor. No contexto digital, o professor tem de gerenciar a seleção de materiais pelo computador e elaborar uma composição escrita, em formato digital, para apresentação em hipertexto ou hipermídia. Da mesma forma, as instruções são planejadas e apresentadas por escrito, mesmo que também o sejam oralmente, em arquivos sonoros ou em tempo real, por ferramentas de comuni- 
cação síncrona. No meio digital, a disposição gráfica, a orientação e a navegação são controladas pelo professor, que desempenha, grosso modo, o papel de web designer. O professor de aulas presenciais também prepara materiais e aula, mas não há um tempo prescrito para esse preparo. Em tese, o professor gasta o tempo que achar necessário ou puder nesse processo. Para apresentação oral em sala de aula, o docente não precisa se preocupar em editar na escrita seu discurso, o plano de seleção de materiais e o conteúdo podem ser esquemas relacionados com tópicos da ementa do curso, rascunhados à mão em uma folha de papel. Como não se pode prever o tempo gasto pelo professor, cada instituição decide como lidar com a carga contratual do docente para remunerá-lo ou não pelo tempo de preparo, aumentando o valor de uma hora-aula. A hora-aula continua sendo a referência da unidade da atividade profissional do professor.

Embora o tempo de pesquisa e de seleção de materiais possa ser semelhante nos dois contextos, no ambiente digital, o trabalho de edição por escrito do plano de conteúdos e instruções deve ser feito pelo professor no contexto digital. Ele não pode contar com um esquema mental ou um plano escrito à mão em um caderno. Além de pesquisar na biblioteca ou em campo, ele pesquisa na rede, lê e seleciona os materiais em arquivos, os captura, edita, estabelece uma sequência e faz upload para um servidor do ambiente digital usado (por exemplo, Moodle, blog ou um servidor web qualquer). Passando para a web, ele tem de selecionar e decidir sobre a disposição dos materiais e das instruções e das ferramentas. Esse trabalho de seleção e de edição no contexto digital consome mais tempo do que a preparação de material para uma aula presencial, sem contar os atrasos por dificuldades técnicas - provedor fora do ar, lentidão da rede, etc. Ainda não se pode prever com precisão o tempo mínimo a ser gasto pelo professor em uma pesquisa e seleção de materiais, mas existe um produto digitalizado que constitui grande parte da aula. Esse produto antecede temporalmente a aula tradicional, que é marcada, no contexto presencial, pelo contato inicial que o aluno tem com esse material, em geral, junto com o professor. Pessoal- 
mente, reservo no mínimo seis meses para elaborar uma disciplina nova antes que seja oferecida pela internet, o que não impede de investir tempo em modificação e revisão durante e após o curso. Em tese, a extensão do material deve ser compatível com o tempo que o aluno tem para estudá-lo, ou que se espera que o aluno tenha para estudá-lo. Uma referência em termos de hora-aula pode ser a carga horária de estudo do discente. Mas o tempo gasto na preparação pode ser muito superior ao tempo que o aluno leva para estudar. Pode-se passar horas na cozinha preparando uma especialidade culinária que será consumida em tempo igual à ingestão de uma sopa instantânea. A reciclagem do material é prevista para outros cursos ou novas versões. No entanto, é uma ilusão dizer que o trabalho de preparação é feito uma vez só. A facilidade e o acesso à edição, bem como o perfil do professor, que procura se atualizar, aliados à dinâmica de interação com os alunos e identificação de novas necessidades, fazem com que os conteúdos passem por uma constante revisão e acréscimo.

De qualquer forma, o material digital, sendo um produto concreto, pode ser mensurado pela configuração de unidades equivalentes a horas-aula. Porém, essa mensuração pressupõe a existência antecipada de alunos, uma previsão que só é possível nos cursos para obtenção de grau de instituições de ensino ou nas situações similares aos cursos de abordagem de língua instrumental que são oferecidos sob encomenda ou medida, com o conhecimento prévio dos alunos obtido por meio de análise de necessidades.

Outro aspecto peculiar e conflitante do trabalho docente no ambiente digital é o da interação entre alunos e professor vista como essencial em qualquer contexto. Como o professor vai usar seu tempo na utilização desse material com seus alunos? Se falamos em professores que dão aulas híbridas ou com apoio de ambientes digitais, o espaço privilegiado da interação interpessoal pode ser o da sala de aula presencial. Nesse caso, a interação pessoa-computador/ material pode ser mais concentrada e explorada em práticas que não exigem interação direta com o professor (por exemplo, atividades automáticas ou com respostas automáticas), de modo que a 
interação em presença seja realizada quando ligada a aspectos mais complexos do assunto abordado. Em um curso oferecido totalmente a distância, o professor pode considerar que certo volume de atividades seja realizado com sucesso pelos alunos em interação entre si, sem necessidade de uma presença constante do professor, reservando sua intervenção para os temas e processos mais complexos. Não faço apologia da independência do aluno, ressaltando que, quando o aluno interage com respostas automáticas, é o professor que pesquisa, seleciona, idealiza e elabora a atividade. Não pretendo retomar aqui o que já se discutiu muito em teorias sobre EaD (Moore, 1993; Garrison, 2000), em relação ao conceito de distância transacional em que, quanto mais os materiais são estruturados e planejados, com ações previsíveis e definidas, maior é a distância transacional, porque não favorece o diálogo, entendido como a interação voltada para a negociação e compreensão de sentidos. Basta salientar que, a meu ver, propostas estruturadas em rede podem favorecer tanto ou mais o diálogo "novo" na relação entre o professor e alunos, assim como podem promover insights indutivamente esclarecedores que dispensam a intervenção complementar do docente. A habilidade de lidar com os materiais coloca o trabalho do professor no plano de um verdadeiro artista plástico, cujo espírito criador luta constantemente com a matéria, para construir sua $\tau \dot{\varepsilon} \chi v \eta$. Para se ter uma ideia, Siragusa, Dixon \& Dixon (2007) indicam 24 dimensões de avaliação da qualidade de desenho instrucional para $e$-learning.

O trabalho do professor em contexto digital também traz impacto na atividade em relação a seus pares. Serei breve nessa explicação, bastando dizer que o custo de produção de material digital e de interação suscita um trabalho de produção em equipe e esquemas de divisão de trabalho. Para haver trabalho em equipe, é necessário que as pessoas se reúnam como um grupo exercendo uma atividade, conseguindo coordenar suas ações e sua comunicação. A criação e organização dessas equipes em meio acadêmico não são alcançadas com facilidade em todas as áreas. Dependendo das rotinas estabelecidas pelo professor, uma mudança ou inovação pode 
afetar o trabalho do docente e até na imagem que tem de sua própria atividade. Mas, sem equipe, é difícil a EaD prosperar em nível institucional.

Creio que uma mudança na relação com os pares dependa ainda de uma reformulação do sistema de ensino. Se professores são contratados para ser responsáveis por disciplinas, como conseguimos ter diferentes professores atuando conjuntamente em uma mesma matéria que requeira especialidades ou habilidades complementares? Como seria possível implementar uma proposta em andamento, de modo que as aulas sejam atividades em que vários professores trabalhem colaborativamente, assim como os alunos? Que conteúdos se prestam de fato a tal implementação? Como se registraria a hora-aula colaborativa? Muitas carreiras não têm ainda especialistas suficientes para compor equipes de $\mathrm{EaD}$, requerendo uma composição interinstitucional para formação de cursos e para elaboração de bases de dados usadas em pesquisas, trabalhos e cursos.

Durante algum tempo achei que um professor poderia se preparar progressivamente para atuar em contexto digital, dentro da rotina assumida, com pequenas alterações em sua rotina, inserindo alguns hábitos do mundo digital - por exemplo, digitando, aos poucos, as instruções e os materiais adotados em classes presenciais, até com a ajuda dos próprios alunos, incentivando-os a se capacitarem no ambiente digital. Sem dúvida, pode ser um ponto de partida, mas dificilmente será uma iniciativa que verterá em realizações efetivas de adoção de docência em EaD em larga escala e de modo de trabalho alternativo ao alcance desse professor, se continuarmos nos mesmos moldes que regulamentam o trabalho do professor presencial, ou seja, sem que se alterem concepções básicas de regulação e regulamentação do trabalho do docente em contexto digital, levando em conta que a mediação didático-pedagógica se faz com recursos tecnológicos e que, embora os participantes ocupem espaços e tempos diversos, têm de compartilhar uma dimensão de linguagem e de aprendizagem. Além da pressão ambiental para uma "ecoformação" ou uma vontade de "autoformação" (ver Frei- 
re, p.13-28 deste livro), a interação entre pares no desenvolvimento de projetos conjuntos é importante para a inclusão, inserção e desenvolvimento da expertise tecnológica e engajamento em EaD.

Em suma, o trabalho do professor que atua a distância não tem sido visto como trabalho, assim como o do docente em geral (talvez com exceção dos representantes da classe junto aos sindicatos). A natureza do trabalho do professor on-line tem características peculiares que não são contempladas pelos órgãos responsáveis pela regulamentação de serviços de $\mathrm{EaD}$. Ao contrário, as regras são modeladas nas representações dos cursos presenciais. A unidade básica que regula os cursos presenciais, também adotada para o credenciamento dos cursos a distância, é o tempo - duração de aula e carga horária (em horas-aula ou créditos). Porém, parece haver, em vários aspectos, uma incompatibilidade entre a carga horária estabelecida para um curso presencial e a para um curso a distância, desde o conceito de hora-aula, até o consumo de tempo maior exigido pelos cursos a distância na execução de ações aparentemente corriqueiras, como a comunicação ou mesmo a produção de materiais. Devemos encontrar urgentemente outros meios de estabelecer unidades de trabalho para o professor que atua no contexto digital e repensar a carga horária de um curso a distância mediado pelo computador. Buscar uma forma de replicar a estrutura do contexto presencial para manter os princípios de regulamentação não só é inviável do ponto de vista do acesso à tecnologia atual como pode ser uma péssima ideia do ponto de vista didático-pedagógico.

\section{Bibliografia}

ABREU-TARDELLI, L. S. O trabalho do professor em EaD na lente da legislação. In: MACHADO, A. R. (Org.). O ensino como trabalho: uma abordagem discursiva. Londrina: Eduel, 2004, p.167-97.

.trabalhodoprofessor@chateducacional.com.br. Aportes para compreender o trabalho do professor iniciante em EaD. São Paulo, 2006. Doutorado - PUC-SP. 
ALMEIDA, M. E. B. Educação e tecnologias no Brasil e em Portugal em três momentos de sua história. Educação, Formação $\mathcal{E}$ Tecnologias, v.1 (1), mai. 2008.

AMIGUES, R. Trabalho do professor e trabalho de ensino. In: MACHADO, A. R. (Org.). O ensino como trabalho: uma abordagem discursiva. Londrina: Eduel, 2004.

ANDERSON, T. Teaching in an online learning context. In: ANDERSON, T.; ELLOUMI, F. (Ed.). Theory and practice of online learning. Athabasca: Athabasca University, 2004, p.273-94. Disponível em <http://cde.athabascau.ca/online_book>.

BRASIL. Decreto n.2.494, de 10 de fevereiro de 1998. Regulamenta Art. 80 da LDB (Lei n.9.394/96). MEC. Secretaria de Educação a Distância. Disponível em <http://portal.mec.gov. $\mathrm{br} / \mathrm{seed} /$ arquivos/pdf/tvescola/leis/D2494.pdf>.

Decreto n.5.622, de 19 de dezembro de 2005. Regulamenta Art. 80 da LDB (Lei n.9.394/96). MEC. Secretaria de Educação a Distância. Disponível em <http://www.planalto.gov. br/ccivil_03/_Ato2004-2006/2005/Decreto/D5622.htm>.

BRONCKART, J.-P. Atividades de linguagem, textos e discursos: por um interacionismo sociodiscursivo. Trad. Anna Rachel Machado e Pericles Cunha. 2.ed. São Paulo: Educ, 2007.

O agir nos discursos: das concepções teóricas às concepções dos trabalhadores. São Paulo: Mercado de Letras, 2008.

; MACHADO, A. R. Procedimentos de análise de textos sobre o trabalho educacional. In: MACHADO, A. R. (Org.). $O$ ensino como trabalho: uma abordagem discursiva. Londrina: Eduel, 2004, p.131-63.

CLOT, Y. A função psicológica do trabalho. Petrópolis: Vozes, 2006.

COLLINS, H. et al. Porque é difícil participar de chats? Revista Brasileira de Linguística Aplicada, 3 (2), p. 41-72, 2003.

FERREIRA, A. A. G. D. Ensino-aprendizagem de língua grega e abordagem instrumental. 14 InPLA: Linguagem, inserção e cidadania. São Paulo: LAEL/PUC-SP, 2004.

Challenges in language e-learning material planning for 
specific target audiences. In: FREIRE, M. (Org.). Learning environments mediated by computers: challenges, applications, and teachers education. Special SC Symposium, Commission on Educational Technology and Language Learning CETaLL. Madison, AILA Conference, 25-29 jul., 2005a.

. Preocupações educacionais em relatórios de TI. In: FREIRE, M.; ABRAHÃO, M. H. V. e BARCELOS, A. M. F. (Org.). Linguística aplicada e contemporaneidade. 1.ed. v.1. São Paulo: Alab; Campinas: Pontes, 2005b, p.219-45.

O ensino do grego a distância. In: Programa de Pós-graduação em Letras Clássicas (Org.). II Simpósio de Estudos Clássicos da USP. São Paulo: Humanitas, 2007, p.159-201.

GARRISON, R. Theoretical challenges for distance education in the 21 $1^{\text {st }}$ Century: a shift from structural to transactional issues. International Review of Research in Open and Distance Learning, v.1, n.1, jun., 2000. Disponível em <http://www.irrodl. org/index.php/irrodl/article/viewFile/2/22>.

MACHADO, A. R. (Org.). O ensino como trabalho: uma abordagem discursiva. 1.ed. Londrina: Eduel, 2004.

MOORE, M. Theory of transactional distance. In: KEEGAN, D. (Ed.). Theoretical principles of distance education. Londres: Routledge, 1993, p. 22-38.

REEVES, T.; REEVES, P. Effective dimensions of interactive learning on the World Wide Web. In: KHAN, B. H. (Ed.). Web-based instruction. Englewood Cliffs: Educational Technologies Publications, 1997, p.59-66.

SIRAGUSA, L.; DIXON, K. C.; DIXON, R. Designing quality e-learning environments in higher education. Proceedings ascilite Singapore, 2007.

VALENTE, J. A.; ALMEIDA, F. J. Visão analítica da informática no Brasil: a questão da formação do professor. Revista Brasileira de Informática na Educação-SBIE, n.1, 1997. 



\title{
Nuevas tecnologías Y SU USO EN EDUCACIÓN
}

\author{
Miguel López Coronado \\ Universidad de Valladolid (España), ETSIT. \\ Grupo de Investigación Reconocido Sociedad de la Información \\ Beatriz Sainz \\ Universidad de Valladolid (España), ETSIT \\ María Agustina Navazo \\ Centro Asociado de UNED Palencia
}

\section{Introducción}

Las nuevas tecnologías están transformando la sociedad actual; las tecnologías de la información y la comunicación están en todas partes.

Actualmente es impensable que una empresa no tenga ordenadores, ni acceso a Internet, ni aplicaciones como SAP, Geneve etc., que ayudan a planificar, gestionar, y controlar tanto los procesos productivos, como a los trabajadores, la facturación, los gastos, el marketing, la productividad, entre otros.

Tampoco podemos concebir las diferentes administraciones sin que sus trabajadores o dirigentes no posean un ordenador con acceso a Internet y con un sinfín de aplicaciones que favorezcan su trabajo. Todos los ministerios y organismos públicos tienen su página web, para publicitarse, dando información tanto de los derechos como de los deberes de los ciudadanos a los que administran.

Un ejemplo claro son las páginas web de los ayuntamientos en donde se publicita las cualidades turísticas del municipio, con sus monumentos, los lugares de interés turístico, los hoteles, los museos, los restaurantes, los parques y jardines, las fiestas patrona- 
les... Todo ello sazonado con los deberes tributarios de los censados en el mismo, los horarios de las dependencias municipales, las palabras de bienvenida del señor Alcalde, o el listado de los miembros de gobierno del municipio.

Un aspecto importante a destacar en España son las grandes facilidades de la Agencia Tributaria Española avanzadilla de la e-administración donde todos los tributos se pueden pagar a distancia, sin necesidad de acudir a sus oficinas.

Los servicios se ven también fuertemente influenciados por las tecnologías de la información y la comunicación. Prácticamente todo el mundo compra los billetes de avión mediante Internet, las reservas de hotel se realizan mediante el mismo sistema, dando lugar a un auge del comercio electrónico.

Las tecnologías de la información y la comunicación se han convertido en el motor del sistema productivo, en todos y cada uno de sus aspectos. Es precisamente éste el elemento diferenciador que caracteriza a la Sociedad de la Información, en el mundo capitalista en que nos movemos.

Precisamente el grado de implantación y su interacción con el sistema productivo nos muestra el grado de desarrollo económico y social de los países. Los países más desarrollados son los que tienen una implantación muy superior al 50\% de las nuevas tecnologías en su tejido económico y social, como USA, UE, Japón, Corea del Sur.

Por ello, en la Sociedad de la Información y del Conocimiento, la utilización de las tecnologías de la información y la comunicación en el ámbito educativo parece normal y necesario.

Para la educación en todos sus niveles, desde su inicio en educación primaria, pasando por la secundaria y llegando a la enseñanza superior o universitaria. Las facilidades que se introducen con las nuevas tecnologías son muchas, puesto que a la función docente habitual se puede añadir todo tipo de complementos que agilizan la capacidad de aprender y los contenidos que se pueden añadir.

En la sociedad donde vivimos, el conocimiento avanza rápidamente, así como su utilización, a través de la innovación, es más acelerada. Los conocimientos aportados por las enseñanzas conven- 
cionales se quedan obsoletos rápidamente y es necesario acudir a una formación continuada para estar al día en el puesto de trabajo.

En el mundo laboral, empieza a ser peligroso quedarse obsoleto, ya que siempre puede haber alguien más preparado para el puesto que se ocupa, o que genere más productividad.

En esta situación hay que aprender rápido y con la mayor cantidad posible de información. Por ello, la utilización de las tecnologías de la información y las comunicaciones se hace imprescindible, algo más que normal y necesario, es una arma para el desarrollo.

Es algo asumido por los pedagogos, los técnicos y los dirigentes de la sociedad actual, lo cual está permitiendo generalizar la educación virtual en sus diferentes aspectos en todos los ámbitos educativos.

\section{Tecnología educativa}

El trabajo muldisciplinar de pedagogos, educadores y técnicos, en un amplio proceso de $\mathrm{I}+\mathrm{D}+\mathrm{i}$, está permitiendo introducir, de una forma creativa, la llamada tecnología educativa en los procesos educativos actuales. ${ }^{1}$ Permitiendo evolucionar de un aprendizaje pasivo a un aprendizaje activo generalizado. Donde las enseñanzas reservadas a las elites se generalicen, al abaratar costos y mejorar calidades (García \& Lavié, 2000).

\section{Tecnologías transmisivas}

La educación a distancia ha ido evolucionando desde la utilización de correspondencia, de teléfono, de medios audiovisuales etc., cuyo único fin era transmitir la información al alumno. Podíamos definir esta etapa de la tecnología educativa como tecnologías transmisivas ya que únicamente se daba información al estudiante, puesto que:

1 Página del centro virtual Cervantes: http://cvc.cervantes.es/obref/formacion_virtual. 
- La información la preparaba y suministraba el profesor.

- La relación entre el profesor y el alumno era mínima.

- En los procedimientos más avanzados existían las tutorías (como en la Universidad Nacional de Enseñanza a Distancia).

- La relación entre alumnos es inexistente.

Lo único que se pretendía en esta etapa de la educación a distancia era aportar la información que el profesor, del curso o asignatura, consideraba necesaria para el aprendizaje del alumno que le permitiera superar una prueba o examen para conseguir un título o un diploma.

\section{Tecnologías interactivas}

El siguiente paso de la educación a distancia, teleformación o e-learning es centrarse en el alumno, y se basa en definir el sistema por el cual él que aprende accede a la información.

- El ordenador actúa como un sistema que aporta información: accede a los contenidos formativos, los ejercicios, las simulaciones etc.

- En función de la interacción del usuario, le propone actividades, lleva un seguimiento de sus acciones y hace una retroalimentación hacia el usuario en función de sus acciones.

- El alumno adquiere habilidades mediante la interacción con la propia herramienta.

- La interacción entre alumnos sigue siendo pobre.

\section{Tecnologías colaborativas}

El paso más evolucionado sería el aprendizaje colaborativo, que es un conjunto de métodos de instrucción y entrenamiento apoyados con tecnología y estrategias para propiciar el desarrollo de habilidades mixtas (aprendizaje y desarrollo personal y social), donde 
cada miembro del grupo es responsable tanto de su aprendizaje como del de los restantes del grupo.

Los usuarios comparten la interacción, el intercambio de ideas y conocimientos entre los miembros del grupo.

Una relación entre las tecnologías educativas y la pedagogía nos da idea de la evolución de las tecnologías educativas, su influencia en la pedagogía y el sujeto sobre el que está centrada la misma.

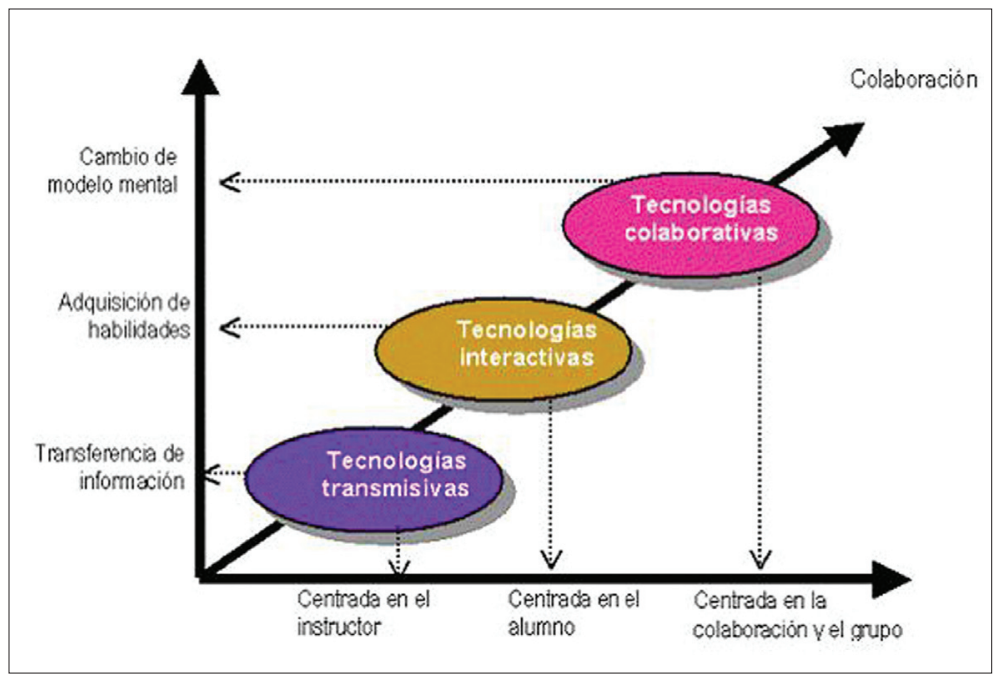

Figura 1 - Relación entre las tecnologías y la pedagogía. Fonte: Casado Ortiz, 2001.

Como venimos diciendo, son las tecnologías de la información y la comunicación las que han introducido dentro de la formación a distancia la posibilidad de disponer de recursos altamente orientados a la interacción y el intercambio de ideas y materiales entre formador y alumnos y de alumnos entre sí.

Las tecnologías de la información y la comunicación pueden contribuir, por sus mismas características de bidireccionalidad e interactividad, a superar estas deficiencias en el aprendizaje no presencial (Ruiz \& Ríos, 1990). 
Este enfoque de aprendizaje cooperativo basado en las tecnologías colaborativas y/o soportes telemáticos como Internet comienza a conocerse como formación on-line, término bajo el que se designa todo un conjunto de métodos que se ajustan especialmente a los principios del aprendizaje de adultos, en el que el intercambio de la experiencia personal con relación a un determinado contenido puede desempeñar un papel relevante en el desarrollo colectivo.

\section{Comunidades virtuales de aprendizaje}

Las comunidades virtuales de aprendizaje (Silvio, 1999) son redes dinámicas para la interacción y conductoras del aprendizaje mediante la potenciación de sus miembros como garantes del conocimiento.

B. Wellman y M. Gulia, en su libro Virtual communities as communities (Wellman, 1999), han mostrado que las comunidades virtuales son también comunidades, aunque sus miembros no tengan proximidad física.

Actualmente, se está produciendo una convergencia entre servicios de almacenamiento y búsqueda de información y servicios de comunicación. La web permite ahora integrar también funciones de comunicación y así ha dado nacimiento a las comunidades virtuales que poseen un sitio web como centro de coordinación tanto de reservorios de información como de comunicaciones.

El sitio web se ha convertido en el "territorio" de una comunidad virtual. Un territorio no geográfico, como el de las comunidades que estudiaron los sociólogos en una etapa del desarrollo de la Sociología, sino un territorio electrónico, distribuido en el nuevo espacio que llamamos "ciberespacio". Existen igualmente programas de ordenadores especializados en la construcción y administración de comunidades virtuales.

Las comunidades virtuales de aprendizaje presentan las mismas características generales de toda comunidad virtual, pero tienen, por supuesto, sus características y responden a necesidades particulares. 
Generalmente, la comunidad comienza por crear un sitio web en el cual existirá un almacenamiento de información en el cual se registrarán los mensajes intercambiados por los alumnos entre si y con el profesor, los documentos que servirán de base al curso y enlaces con otros sitios web que sean relevantes para el tema de discusión del grupo.

De esta forma, el sitio web define el territorio virtual de la futura comunidad y establece actividades a realizar y lugares a visitar. Igualmente, surge una forma de gobierno al establecerse las reglas de participación en el grupo y las normas referentes al proceso de aprendizaje.

En el paradigma tradicional, el conductor del aprendizaje es el profesor y la organización educativa a la cual pertenece. En el nuevo paradigma, el conductor es la comunidad virtual de aprendizaje, en la cual el profesor y la organización son facilitadoras.

Conviene incidir, brevemente, en la función de las tecnologías de la información y la comunicación en las comunidades virtuales de aprendizaje. Esta es garantizar la enseñanza a distancia por vía telemática mediante nuevos entornos virtuales de aprendizaje (EVA), que deben ser: interactivos, amigables, participativos y colaborativos. Siendo Internet el soporte que le da agilidad a la distancia.

\section{Internet}

Como acabamos de decir es Internet quien da agilidad a la distancia, por lo tanto es imprescindible que las partes interesadas en e-learning estén conectadas a la red de redes.

La situación y penetración de Internet es síntoma del desarrollo de los países. Por lo tanto, estos datos actualizados a 2007 y distribuidos por regiones en millones de habitantes, tanto por ciento de penetración y evolución, desde 2000 a 2007, aparecen en la Tabla 1 (www.internetworldstast.com). 


\begin{tabular}{|l|c|c|c|c|}
\hline \multicolumn{1}{|c|}{ Región } & Población & $\begin{array}{c}\text { Uso de } \\
\text { internet }\end{array}$ & Penetración & $2000-2007$ \\
\hline África & 941,2 & 44,4 & $4,7 \%$ & $882,7 \%$ \\
\hline Asia & $3.733,8$ & 510,5 & $13,7 \%$ & $346,6 \%$ \\
\hline Europa & 801,8 & 348,1 & $43,4 \%$ & $231,2 \%$ \\
\hline Oriente M. & 192,7 & 33,5 & $17,4 \%$ & $920,2 \%$ \\
\hline América N. & 334,6 & 238 & $71,1 \%$ & $120,2 \%$ \\
\hline América S. & 569,1 & 126,2 & $9,6 \%$ & $598,5 \%$ \\
\hline Oceanía & 33,6 & 19,1 & $57,1 \%$ & $151,6 \%$ \\
\hline Total & $6.606,9$ & $1.319,8$ & $20,0 \%$ & $265,6 \%$ \\
\hline
\end{tabular}

Tabla 1 - Estudio regional y evolución de Internet en los últimos años en millones de habitantes.

Se ve claramente una penetración alta en América del Norte, Oceanía y Europa. Hay que tener en cuenta que estudios más detallados por países darían penetraciones muy superiores en países de la Unión Europea y en países Sudamericanos, tales como Brasil y Chile.

El índice de penetración en los países en desarrollo o en vías de desarrollo es suficientemente alto para pensar que la virtualidad se garantilla en la mayoría de dichos países.

Incluso en algunos, el grado de penetración y de utilización en temas como comercio electrónico, e-ocio, e-administración, e-salud y e-educación está exigiendo subir las velocidades de transmisión a niveles considerados altos, rozando los cien Mbytis, con tecnología suficientemente sofisticada para la utilización de soportes convencionales.

\section{La evolución de la web}

Web o la Web, la red o www de World Wide Web, es básicamente un medio de comunicación de texto, gráficos y otros objetos multi- 
media a través de Internet, o sea, la web es un sistema de hipertexto que utiliza Internet como su mecanismo de transporte o, desde otro punto de vista, una forma gráfica de explorar Internet.

La web fue creada en 1989 en un instituto de investigación de Suiza. Ella se basa en buscadores y el protocolo de transporte de hipertexto (hypertext transport protocol - http). La mayoría de los documentos de la web se crean utilizando lenguaje HTML (hipertexto markup language).

Es importante saber que web o www no son sinónimo de Internet, la web es un subconjunto de Internet que consiste en páginas a las que se puede acceder usando un navegador. Internet es la red de redes donde está toda la información. Tanto el correo electrónico, como FTPs, juegos etc. son parte de Internet, pero no de la web.

Para buscar hipertexto se utilizan programas llamados buscadores web que recuperan trozos de información (llamados documentos o páginas web) de los servidores web y muestran en la pantalla del ordenador de la persona que está buscando la información gráfica, textual o video e incluso audio.

Después se pueden seguir enlaces o hyperlinks en cada página a otros documentos o incluso devolver información al servidor para interactuar con él. Al acto de seguir un enlace tras otro a veces se le llama navegar en Internet.

La web se ha convertido en un medio muy popular de publicar información en Internet, y con el desarrollo del protocolo de transferencia segura (secured server protocol - http), la web es ahora un medio de comercio electrónico donde los consumidores pueden escoger sus productos on-line y realizar sus compras utilizando la información de sus tarjetas bancarias de forma segura.

Y como no es el soporte vehicular de enseñanza a distancia, teledecación, e-learning...

Sería bueno observar la web como el estado del www, desde, por ejemplo, 1994 hasta la actualidad. Dicha evolución la podemos dividir en dos etapas, aquella que denominamos Web 1.0, que llega hasta 2004, y la Web 2.0, que se desarrolla a partir de dicho año hasta la actualidad. 


\section{La Web 1.0}

La Web 1.0 se refiere al estado del World Wide Web desde 1994 hasta 2004. Los sitios web eran un modo de publicación en sentido único: web $\rightarrow$ usuario.

Si nos centramos en la web docente, esta era el conjunto de páginas creadas como soporte para la educación. Era creada por el profesor para la enseñanza de una asignatura. Dicho programa de la asignatura, constaba de objetivos, contenidos, evaluación, materiales (como apuntes y referencias), noticias, calendario de eventos, tablón de anuncios, así como enlaces de interés. Era una web estática donde se creaban páginas y se almacenaban en un servidor.

Para ello se disponía de:

- Editores HTML, como Dreamweaver.

- Gráficos como Gimp, Photoshop, CorelDraw.

- Multimedia, como Flash.

- Programación, como JavaScript, Java.

- Publicación en el servidor como FTP, filezilla...

También se disponía de sitios web dinámicos, donde la información se obtenía de una base de datos dinámicamente. Como ejemplo de ello tenemos:

- $\mathrm{PHP}+\mathrm{mSQL}$

\section{La Web 2.0}

La Web 2.0 es la representación de la evolución de las aplicaciones tradicionales hacia aplicaciones web enfocadas al usuario final. La Web 2.0 es una actitud y no precisamente una tecnología.

LaWeb 2.0 es la transición que se ha dado de aplicaciones tradicionales hacia aplicaciones que funcionan a través del web enfocadas al usuario final. Se trata de aplicaciones que generen colaboración y de servicios que reemplacen las aplicaciones de escritorio.

Es una etapa que ha definido nuevos proyectos en Internet y está preocupándose por brindar mejores soluciones para el usuario 
final. Muchos aseguran que hemos reinventado lo que era el Internet, otros hablan de burbujas e inversiones, pero la realidad es que la evolución natural del medio realmente ha propuesto cosas más interesantes como lo analizamos diariamente en las notas de Actualidad.

Y es que cuando la web se inició, nos encontrábamos en un entorno estático, con páginas en HTML que sufrían pocas actualizaciones y no tenían interacción con el usuario.

Pero para entender de donde viene el término de Web 2.0 tenemos que remontarnos al momento en que Dale Dougherty de O'Reilly utilizó este término en una conferencia en la que compartió una lluvia de ideas junto a Craig Cline de MediaLive. En dicho evento se hablaba del renacimiento y evolución de la web.

Constantemente estaban surgiendo nuevas aplicaciones y sitios con sorprendentes funcionalidades. Y así se dio la pauta para la Web 2.0 Conference, que arranca en el 2004, y hoy en día se realiza anualmente en San Francisco, con eventos adicionales utilizando la marca en otros países.

En la charla inicial del Web Conference se habló de los principios que tenían las aplicaciones Web 2.0:

- LaWeb es la plataforma.

- La información es lo que mueve al Internet.

- Efectos de la red movidos por una arquitectura de participación.

- La innovación surge de características distribuidas por desarrolladores independientes.

- El fin del círculo de adopción de software, pues tenemos servicios en beta perpetuo.

Entender la evolución que ha llegado con la Web 2.0 puede realizarse con ejemplos, con proyectos. Podemos comparar servicios web que marcan claramente la evolución hacia el Web 2.0 con una nueva forma de hacer las cosas:

- Web $1.0 \rightarrow$ Web 2.0.

- Doubleclick $\rightarrow$ Google AdSense (servicios publicidad).

- Ofoto $\rightarrow$ Flickr (comunidades fotográficas). 
- Akamai $\rightarrow$ BitTorrent (distribución de contenidos).

- mp3.com $\rightarrow$ Napster (descarga de músicas).

- Britannica Online $\rightarrow$ Wikipedia (enciclopedias).

- Sitios personales $\rightarrow$ Blogs (páginas personales).

- Especulación con dominios $\rightarrow$ Optimización en motores de búsqueda SEO (Search Engine Optimization).

- Páginas vistas $\rightarrow$ Costo por click.

- $\mathrm{CMSs} \rightarrow$ Wikis (administradores de contenidos).

- Cate.

El Web 2.0 no significa precisamente que existe una receta para que todas nuestras aplicaciones web entren en este esquema. Sin embargo, existen varias tecnologías que están utilizándose actualmente y que deberíamos de examinar con más cuidado en busca de seguir evolucionando junto al web.

- Transformar software de escritorio hacia la plataforma del web.

- Respeto a los estándares como el XHTML.

- Separación de contenido del diseño con uso de hojas de estilo.

- Sindicación de contenidos.

- Ajax (javascript ascincrónico y xml).

- Uso de Flash, Flex o Lazlo.

- Uso de Ruby on Rails para programar páginas dinámicas.

- Utilización de redes sociales al manejar usuarios y comunidades.

- Dar control total a los usuarios en el manejo de su información.

- Proveer APis o XML para que las aplicaciones puedan ser manipuladas por otros.

- Facilitar el posicionamiento con URL sencillos.

El uso de el término de Web 2.0 está de moda, dándole mucho peso a una tendencia que ha estado presente desde hace algún tiempo. En Internet las especulaciones han sido causantes de grandes burbujas tecnológicas y han hecho fracasar a muchos proyectos.

El Web 2.0 no es precisamente una tecnología, sino es la actitud 
con la que debemos trabajar para desarrollar en Internet. Tal vez allí está la reflexión más importante del Web 2.0.

De todo lo dicho hasta ahora podemos concretar una serie de herramientas con uso docente de gran importancia para la evolución de las tecnologías colaborativas:

- Wiki: web colaborativo que puede ser editado por varios usuarios. Está organizado por páginas, tiene una carácter más dinámico, una organización atemporal y orientado a la colaboración.

- Blogs: es un espacio de comunicación, con un formato ágil, rápido y funcional. Está organizado por entradas, su carácter es estático, se organiza cronológicamente y está más orientado hacia el trabajo personal. Está organizado por páginas, tiene una carácter más dinámico, una organización atemporal y orientado a la colaboración.

- RSS: usado para redifundir contenidos a suscriptores de una web.

- CMS: moodle.

- Webquest: que consiste en una actividad de aprendizaje en la que el alumno lee, analiza y sintetiza información utilizando el www. El profesor es el que anima a los alumnos a que construyan activamente, según su propio entendimiento, un tema. Esto es posible gracias a la resolución de problemas, la respuesta de preguntas y la cooperación entre los alumnos. En este caso, no es necesaria la construcción de un sitio web. Ejemplo de ello es WebQuest.

\section{El entorno virtual de aprendizaje}

Entonces el VLE, entorno virtual de aprendizaje, se concreta en:

- En un sistema software diseñado para soportar la enseñanza y el aprendizaje en un contexto educativo.

- Hacer uso de Internet (e-learning).

- Proporcionar herramientas para comunicación, subida de 
contenidos, recogida de trabajos de los alumnos, gestión de grupos, cuestionarios, exámenes, seguimiento de alumnos, gestión de notas, calendarios, anuncios y casi todo lo que se nos pueda ocurrir.

- Incluye características nuevas como blogs y RSS.

- Favorece el aprendizaje combinado: blended learning.

- Sus ventajas son:

o Economizar el tiempo de los docentes.

o Hacer que Internet se convierta en un medio natural de encontrar información y recursos para los estudiantes.

o Facilitar el control de la calidad de la información recogida.

o La integración de la educación presencial y a distancia.

Se pueden disponer incluso de más herramientas para uso docente:

- Blog del profesor, para guiar a los alumnos en su estudio.

- Blog y wiki de la asignatura para el desarrollo de temas.

- Google Docs.

- Etiqueta específica en del.icio.us para una materia.

- Vídeos en YouTube.

- Fotos en Flickr.

- Podcast.

- SlideShare.

- RSS, con noticias y eventos de la asignatura.

\section{E-learning 2.0}

La aplicación de todo lo dicho a la educación a distancia recibe el nombre de e-learning 2.0 y está caracterizado por aspectos de gran interés para garantizar la extensión y mejora de la educación: ${ }^{2}$

2 Página dedicada al e-learning disponible en: $<\mathrm{http}$ // /elearning.ciberaula.com/ $\mathrm{x}$. Artículos sobre blended learning disponible en: <http://www.edu.yorku.ca:8080/ $\sim$ rowston/>. 
- La reducción de costes (acarreados por el desplazamiento, alojamiento etc.).

- La eliminación de barreras espaciales y la flexibilidad temporal.

- El aprendizaje no se basa en objetos y contenidos almacenados, sino que fluye por la red y se puede recoger.

- Se centra en los intereses del alumno.

- Este tipo de aprendizaje, se realiza por inmersión, es decir, que se aprende haciendo.

- Es un aprendizaje "conectado", donde la computadora conecta al alumno con el mundo.

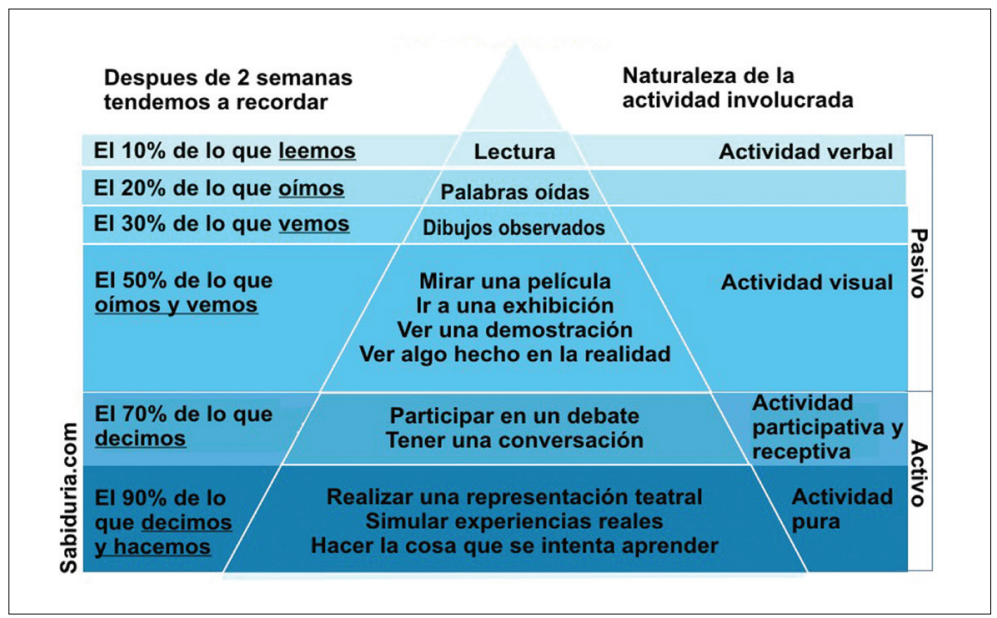

Figura 2 - El cono del aprendizaje.

Fonte: Dale, 1969.

Si nos fijamos en el cono de aprendizaje de Edgar Dale y las $^{3}$ ventajas y características del e-learning 2.0, vemos cuanto más activo sea el aprendizaje del alumno, y por tanto la naturaleza de la ac-

3 Ver página sobre el cono del conocimiento disponible en: <http://bitacoradelgaleon.blogspot.com/2007/05/edgar-dale-y-el-cono-de-aprendizaje.html>. Sobre el cono del conocimiento ver página disponible en: <www.sabiduría.com>. 
tividad que desarrolla para el mismo, mayor será la retención de los contenidos.

\section{Necesidades tecnológicas y de infraestructuras par la calidad de la educación a distancia}

Las tecnologías colaborativas, como hemos visto, requieren:

- Aumento en la complejidad de las técnicas.

- Mayor calidad en la comunicación entre los miembros de la comunidad virtual de aprendizaje.

- Más capacidad de procesamiento.

- Más capacidad de almacenamiento.

- Total bidireccionalidad de las comunicaciones.

- Gran capacidad de transmisión de información por la red.

Si vamos sumando el desarrollo y complejidad de las tecnologías que dan satisfacción al e-learning 2.0 y a la realidad social, Internet necesita cada vez más disponer de una capacidad de transmisión varios ordenes de magnitud superior a la que se dispone.

Las técnicas colaborativas deben de disponer de una bidireccionalidad total, actualmente la parte descendente es mucho mayor que la ascendente. La calidad de servicio (QoS) no está garantizada. De hecho los contratos de operadores de telecomunicaciones suministradores de Internet no garantizan más que un máximo de velocidad de transmisión, no un mínimo o velocidad constante.

Las direcciones IP están llegando a su saturación puesto que el uso de Internet, como hemos visto en el apartado 3, ha aumentado $265,6 \%$ entre 2000 y 2007. Tampoco podemos olvidar el aumento de usuarios, de forma exponencial, que los países emergentes (China, India y otros países asiáticos densamente poblados) van a plantear.

A todo ello hay que sumarle las necesidades que aparecen en el uso habitual de Internet, tanto en materia de ocio (video), como para satisfacer necesidades económicas (comercio electrónico, adquisición de información, teletrabajo...). 
Por lo tanto no es difícil llegar a la conclusión que con lo que tenemos es insuficiente, hay que evolucionar.

La comunicación, o sea Internet, debe garantizar la disponibilidad de direcciones IP para hacer frente a las exigencias de los usuarios, acudiendo a otro protocolo mucho más potente.

Los operadores de Pay-TV y algunas instituciones educativas con grandes redes de ordenadores han usado la multidifusión IP para ofrecer streaming (ver u oír un archivo directamente en una página web sin necesidad de descargarlo antes al ordenador) de vídeo y audio a alta velocidad a un gran grupo de receptores. Ello solo se puede garantizar mediante un significativo aumento de la velocidad de transmisión o transferencia.

Se necesitan unas tecnologías que garanticen la transmisión de cierta cantidad de datos en un tiempo dado (throughput). Ello se consigue mediante calidad de servicio (QoS) que no es más que la capacidad de dar un buen servicio.

Ello requiere de un nuevo Internet y como consecuencia de actualizar las infraestructuras necesarias para poder garantizar estas velocidades de transmisión y de las nuevas tecnologías a implementar, que pasan por el acceso al terminal del ordenador mediante fibra óptica.

\section{Internet 2}

En Chicago, en Octubre de 1996, 34 Universidades norteamericanas se reúnen para crear UCAID (The University Corporation for Advanced Internet Development). Corporación Universitaria que promueve esta nueva red en Estados Unidos, agrupando a universidades, centros de investigación, oficinas gubernamentales y empresas que proporcionan infraestructura de telecomunicaciones y dan lugar a la aparición de Internet 2.

Los objetivos de Internet 2: es crear y mantener una red de alta capacidad para la comunidad científica, desarrollar aplicaciones avanzadas, crear una infraestructura con una alta QoS y desarrollar 
nuevas aplicaciones que puedan mejorar la colaboración entre investigadores.

\section{Componentes tecnológicos de Internet 2}

Hay que introducir una serie de innovaciones tecnológicas que garanticen las nuevas exigencias que están centradas en puntos de interconexión acordes con velocidades de transferencia de como mínimo decenas de Gigabps, un nuevo protocolo de encaminamiento que aumente su rendimiento, interconexiones e infraestructuras que permitan esos anchos de banda. Todo ello con una calidad de servicio bidireccional totalmente garantizado.

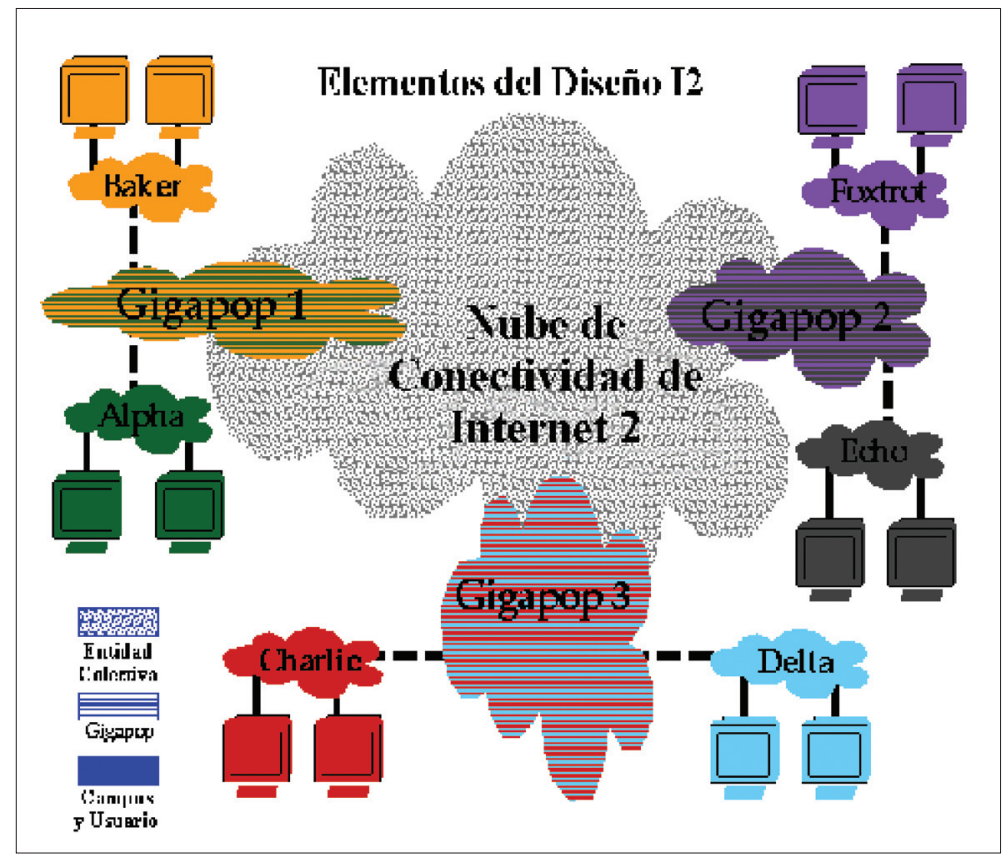

Figura 3 - Arquitectura de Internet $2 .^{4}$

4 Ver página sobre Internet 2 en: <http://es.wikipedia.org/wiki/Internet2>. 
- Gigapops (gigabit capacity point of presence): puntos de interconexión de tecnología avanzada y alta capacidad donde los participantes de Internet 2 pueden intercambiar tráfico de servicios avanzados con otros participantes del proyecto. Ofreciendo acceso a Internet e Internet 2.

- Protocolo de encaminamiento: IPv6. Este nuevo protocolo produce una expansión de capacidades de enrutamiento y direccionamiento, da solución al problema de direcciones dando un número muy superior de direcciones (del orden de 1.038) dado que esta se representa con 128 bits y soporta mejores estructuras jerárquicas, seguridad e integridad de datos, calidad de servicio y soporte de tráfico multimedia en tiempo real.

\section{Aplicaciones que requieren servicios de nivel Internet 2}

\section{Bibliotecas Digitales}

Una Biblioteca Digital es una colección organizada de documentos almacenados en formato digital, que ofrece los servicios de búsqueda y recuperación de información.

Suministra:

- Acceso a bases de datos.

- Consulta de tablas de contenido de revistas.

- Consulta de libros electrónicos (e-books), capítulos de libros o reportes internos.

- Acceso a programas multimedia.

- Uso de obras de consulta como enciclopedias, diccionarios, almanaques, entre otros.

- Películas, videos y clips digitales de carácter recreativo, cultural o científico.

- Enlaces a recursos digitales.

- Consulta de OPAC's. 


\section{Teleinmersión}

Es la combinación eficaz de sistemas avanzados de telecomunicaciones que permiten aplicaciones colaborativas de manera fluida. Consiste en la transmisión entre puntos distantes de escenas sintetizadas tridimensionales y a tamaño real, representadas y renderizadas (es decir, dotadas de texturas y volúmenes) en tiempo real, empleando técnicas avanzadas de visión y gráficos digitales.

Requiere de gran ancho de banda, bajo retardo y comunicaciones síncronas y de redes de alta velocidad que incorporen protocolos avanzados como el ATM, RSVP, MPLS y multicast.

\section{Nueva Generación de Redes (NGN)}

Las infraestructuras, el medio de comunicación, que garanticen el tránsito de las comunicaciones ultra rápidas para posibilitar Internet 2 han de ser soportadas por fibra óptica, y como vemos en la Figura 4, esta debe de llegar hasta el mismo terminal, normalmente el ordenador que utilicemos.

Las tecnologías de ADSL entrarán en crisis con la fibra óptica teniendo que adaptarse los operadores de telecomunicaciones a las infraestructuras ultra rápidas.

La necesidad de implementar nuevas infraestructuras ultra rápidas plantea un reto económico importante. Como se va a garantizar el acceso a Internet 2 cuando no se garantiza el carácter universal de Internet. En la Unión Europea, en esta década, se ha lanzado directivas en donde se pretende que estas necesidades se cumplan tanto en el medio urbano como en el medio rural. La cobertura universal de Internet en el medio rural se conseguirá con subvenciones y tecnologías alternativas.

\section{Conclusiones}

La educación a distancia ha evolucionado desde posiciones transmisivas a posiciones colaborativas donde el alumno está in- 
merso en su formación desde un punto de vista totalmente activo. De acuerdo con el cono de aprendizaje de Edgar Dale, vemos que cuanto más activo es el aprendizaje del alumno, y por tanto la naturaleza de la actividad que desarrolla para el mismo, mayor es la retención de los contenidos. Con las nuevas tecnologías que se implantarán alrededor de Internet 2 y sus aplicaciones, el alumno tendrá más facilidades para comprometerse con su formación.

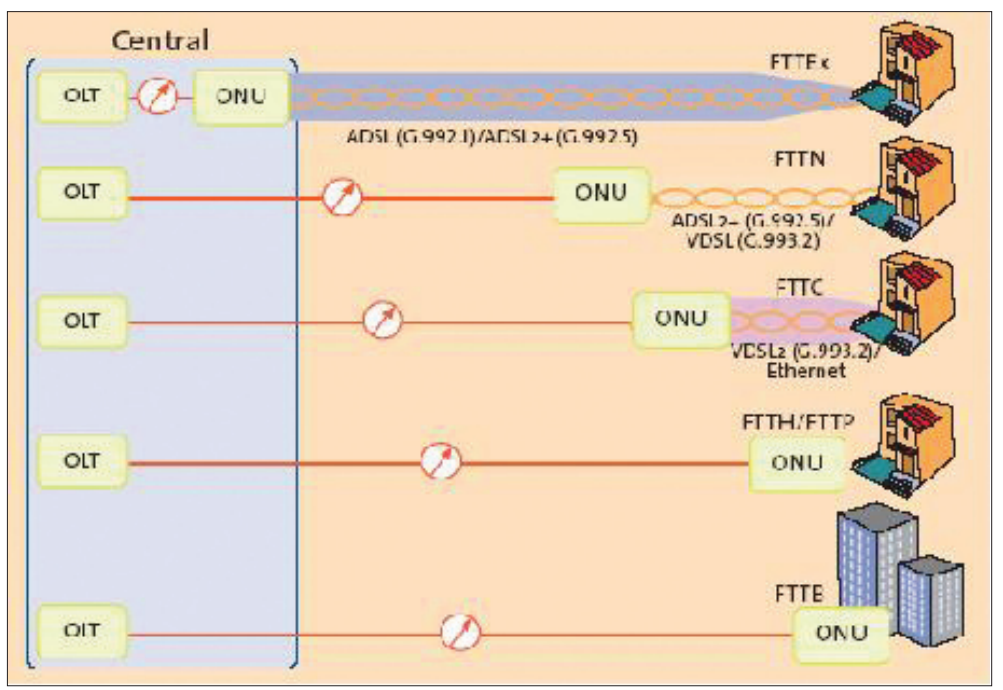

Figura 4 - Arquitectura de redes de acceso de nueva generación. ${ }^{5}$

La tecnología que soporta esa capacidad de comunicación bidireccional, que caracteriza la educación colaborativa a distancia, ha aumentado su complejidad, desde un punto de vista tecnológico, pero se ha permitido a los usuarios alumnos y profesores disponer de un sistema mucho más amigable y fácil de utilizar.

Las webs utilizadas en e-learning, cada vez son más evolucionadas y son sustituidas por un rango superior de complejidad cada

5 Ver página sobre FTTH en <http://es.wikipedia.org/wiki/FTTH>. 
década. ${ }^{6}$ Se ha hablado de la Web 2.0 pero ya se está pensando en la Web 3.0 de cara a 2010.

La complejidad tecnológica ha obligado a disponer de terminales mucho más potentes, más memoria e interfases más complejas, y a comunicaciones bidireccionales (síncronas) con velocidades de transferencia muy superiores a cien megabps y con una calidad de servicio (QoS) contrastada. Permitiendo, de esta forma, que la tecnología junto a sus infraestructuras, la utilizaciones de aplicaciones que potencian al máximo la educación a distancia colaborativa.

Así mismo, la complejidad de las tecnologías y de las aplicaciones desarrolladas en la actualidad - video streaming, IPTV, teleinmersión - está obligando a sustituir, en cada país, Internet por Internet 2 , que permite trabajar con velocidades de transferencia del orden de las decenas de gigabps.

Infraestructuras ultra rápidas deben garantizar velocidades de transferencia superiores a las decenas de gigabps, ello únicamente se garantiza con la fibra óptica, teniendo que acceder, ésta, al terminal del usuario mediante tecnologías FTTH.

\section{Bibliografia}

CASADO ORTIZ, R. El aprovechamiento de las tecnologías de la información y la comunicación (TIC) para la creación de redes de aprendizaje colaborativo: la experiencia de Telefónica de España. Training E Development Digest, Mayo, 2001.

DALE, E. Audio-Visual Methods in Teaching. 3.ed. New York: The Dryden Press, 1969.

GARCIA, C. M.; LAVIÉ, J. M. Formación y nuevas tecnologías: posibilidades y condiciones de la teleformación como espacio de aprendizaje. Bordón-Revista de pedagogía. v.52, n.3, p.385-406, 2000 .

6 Ver página sobre evolución de la web en: <http://www.blumex.net/grafico-de-la-posible-evolucion-de-la-web/>. 
RUIZ, C.; RÍOS, P. El uso de la informática en la educación. Investigación y postgrado. v.5, n.2, p.59-89, 1990.

SILVIO, J. Las comunidades virtuales como conductoras del aprendizage permanente. In: Simposio sobre Sistemas de Aprendizaje Virtual. Caracas, 1999. Caracas: Red Iberoamericana de Informática Educativa (Ribie), Centro Internacional de Educación y Desarrollo (Cied) de la Compañía Petróleos de Venezuelayel Iesalc/Unesco, 1999. Disponívelem<http://funredes. $\mathrm{org} / \mathrm{mistica} /$ castellano/ciberoteca/participantes/docuparti/ esp_doc_31.html>. Acceso en 25/7/2009.

WELLMAN, B.; GULIA, M. Virtual communities as communities: net surfers don't ride alone. Londres: Routledge, 1999. 



\title{
DESIGN DE MATERIAL DIDÁTICO ON-LINE: REFLEXÕES
}

\author{
Rosinda de Castro Guerra Ramos \\ Pontifícia Universidade Católica de São Paulo
}

\section{Introdução}

O desenvolvimento desenfreado de cursos e materiais para ensino-aprendizagem de línguas via computador nos últimos anos pode nos levar a pensar que ainda não há muitos profissionais que possuam formação formal nessa área. Assim, acredito que trazer contribuições pessoais e práticas para esse campo seja não só uma forma de intercâmbio de ideias e experiências entre os profissionais interessados, mas também uma forma de agregar conhecimento a uma área de estudo que ainda está em franca expansão.

A partir dessa colocação, chega-se à proposta deste trabalho que se fundamenta em minha experiência de pesquisadora, professora, avaliadora e designer de materiais didáticos para aulas presenciais e, com o advento da era digital, designer de materiais e cursos na ambientação virtual. É mais especificamente nessa experiência que focalizo minha apresentação. O objetivo é fazer alguns questionamentos que possam contribuir para as demandas geradas pelas premissas da sociedade do conhecimento em sintonia com as Tecnologias da Informação e Comunicação (TICs) (Jonassen, 1996, Maia, 2000, Niskier, 1999, entre outros). Inicio com questões relativas à conceituação de material didático e de design de materiais, 
fazendo, a seguir, um paralelo com o advento do computador e ilustrando com exemplos de material didático elaborado para cursos on- line. Finalizo com algumas ponderações e desafios que se colocam para o professor designer de língua estrangeira que, hoje, se defronta com a tarefa de produzir materiais para a ambientação on-line.

\section{Alguns conceitos}

Acho necessário expor algumas definições sobre o que é material didático e design para compartilhar conceitos afins.

Damianovic (2007, p.20), utilizando a perspectiva vygotskiana, conceitua material didático e elaboração da seguinte maneira:

Entendo material didático como sendo um artefato de mediação (Vygotsky, 2000) e vejo o processo de elaborar material didático como uma atividade de criação de sentidos e significados que tem como principal artefato cultural a linguagem.

Embora essa definição tente articular-se com uma perspectiva corrente, tanto nos documentos oficiais como nos trabalhos desenvolvidos sobre ensino-aprendizagem de línguas, prefiro tomar como ponto de partida uma acepção mais ampla para material didático e, nesse sentido, faço minhas as palavras de Tomlinson (2001, p.66):

Anything can be used to facilitate the learning of a language. They can be linguistic, visual, auditory or kinesthetic, and they can be presented in print, through live performance or display, or on cassette, CD-ROM, DVD or the internet.

Essa definição, embora ampla, deixa claro para professores, principalmente, que tudo que usarmos como recurso que ajude o aluno a aprender poderá ser compreendido como material didático. Assim, podemos ir de uma simples figura extraída de uma revista, para o uso de cartazes e objetos até os mais sofisticados recursos tecnológicos à disposição do professor. Além disso, deixa subenten- 
dido que professores podem também ser considerados designers de materiais.

Complementando a concepção de material didático, é preciso que se pense que há um design que governa esse produto e há um processo de construção para que se concretize uma atividade de ensino-aprendizagem. Nas palavras de Tomlinson (1998, p.2):

Materials development refers to anything which is done by writers, teachers or leaners to provide sources of language input and to exploit those sources in ways which maximise the likelihood of intake: in other words the supplying of information about and/or experience of language in ways designed to promote language learning.

Portanto, ao considerar-se a produção de material didático, é preciso ter princípios teóricos de ensino-aprendizagem, de linguagem e de procedimentos que norteiem essa produção, para que o input linguístico possa ser combinado, processado e apresentado "de forma criativa e precisa, em um contexto histórico, social e organizacional mais amplo” (Filatro, 2008, p.7).

Não é intuito deste trabalho discutir todos esses princípios e procedimentos, mas gostaria de pontuar alguns deles, encontrados na literatura (Dudley-Evans \& St. John, 1998; Graves, 2000; Hutchinson \& Waters, 1997; Tomlison, 1998, 2001, 2003, entre outros), por considerá-los importantes, dadas minhas crenças do que seja linguagem e ensino-aprendizagem.

O primeiro deles - causar impacto - é muito importante, pois, ao se desenhar o material, suas potencialidades - novidade, variedade, atração, etc. - devem ser levadas em conta para que ele possa atrair a atenção do aluno, despertando seu interesse e curiosidade.

O segundo - estimular e motivar os alunos - leva o designer a pensar quais elementos poderão auxiliar a tarefa de aprender, tais como grau de desafio e de solução, o equilíbrio entre o que é novo e conhecido, o grau de conexão com a realidade do aluno, entre outros.

Outro princípio - desenvolver confiança e fazer os alunos sentir-se confortáveis - envolve considerações sobre como o material pode dar 
ao aluno segurança de que obterá sucesso ao se engajar nas atividades que lhe são apresentadas, criando senso de realização e, ao mesmo tempo, possibilitando elevar sua autoestima. Ele também precisará proporcionar sentimentos de relaxamento e evitar ansiedade.

Já os itens perceber a relevância e possibilitar "descobertas" e responsabilidade alinham-se à busca de aspectos que sejam significativos para o aluno e à possibilidade de sentir que de alguma forma o que será trabalhado tem e terá sentido para sua vida. Ao mesmo tempo, o material precisa propiciar momentos em que o próprio aluno faça inferências, busque respostas, crie um sentimento de que a construção do conhecimento acontece porque ele está empenhado em sua realização. Em outras palavras, deve auxiliar o estudante em seu caminho de autonomia na aprendizagem.

Usar a língua-alvo para propósitos comunicativos visa fazer com que os materiais facultem situações de comunicação que envolvam os alunos e os engajem discursivamente em vivenciar práticas sociais por meio da linguagem, ao invés da prática controlada e/ou descontextualizada, como em geral acontece.

Usar o feedback para eficácia do resultado de aprendizagem significa que é preciso buscar possibilidades de avaliar o que é produzido em relação aos objetivos propostos, o que aconteceu durante o processo, e não mais só a exclusiva verificação do produto. Assim, é possível fazer com que esse componente seja também usado para o melhoramento da própria aprendizagem.

Acrescento a esses itens outros princípios de igual importância que também precisam ser considerados: o perfil dos alunos e suas necessidades (há casos em que o material é desenhado para um grupo potencial); os objetivos a que eles se destinam; quais conteúdos se fazem necessários para o desempenho eficaz das atividades.

Esclareço ainda que, ao escolher esses alicerces teóricos, os papéis do professor, como facilitador, orientador ou mesmo mediador, e do aluno, como cocolaborador, participativo, responsável por sua aprendizagem, já são pressupostos.

Uma vez feitas essas colocações, pode-se perceber que o design 
de materiais não é uma tarefa tão simples como alguns imaginam, pois envolve planejar, analisar, selecionar, adaptar, criar, avaliar, sempre embasado nos elementos apontados acima.

\section{O advento do computador: o novo ambiente de ensino-aprendizagem}

Com o advento do computador, o que aconteceu com os materiais usados para o ensino-aprendizagem de línguas? Primeiro, não podemos esquecer que hoje esse recurso já tem uma pequena história na área de ensino-aprendizagem de línguas (ver Warschauer \& Healey, 1998). Entretanto, a entrada da internet, ponto no qual vou me ater, configurou outro momento. Novas ferramentas apareceram em uma velocidade nunca vista: buscadores (por exemplo, Google), sites disponíveis com uma gama infinita de possibilidades de temas e usos, e-mails, listas de discussão, chats, blogs, teleconferências, programas de autoria, plataformas, MSN, ORKUT, Second Life, entre outros. Se temos todos esses recursos disponíveis, como podemos pensar o desenho de materiais para essa ambientação que não sejam mais aqueles elaborados para serem usados literalmente face a face? O que envolve pensar, então, o material didático para o ambiente digital?

Um primeiro ponto a ser esclarecido é que os princípios e componentes comentados acima também guiarão os materiais digitais.

Entretanto, é preciso lembrar que o ensino pelo computador traz mudanças nas relações de tempo e espaço que, por sua vez, trazem mudanças nas interações. Essas diferenças, aliadas ao uso do tipo de ferramenta, fará com que o design precise combinar as atividades a serem desenhadas com as características próprias de cada uma das ferramentas (Ramos \& Freire, 2003).

Como fica, então, a aula na virtualidade? Primeiro, não estamos mais face a face e, se estivermos, estaremos mediados pelo computador. Não estamos mais no mesmo lugar, cidade ou país. Poderemos também estar sozinhos, sem o professor e os colegas, ou com um deles ou todos eles. Em relação ao tempo, podemos nos comu- 
nicar assincronamente (horas e dias diferentes) ou em tempo real (sincronamente). Além disso, o computador possibilita novas formas de conversação. Por exemplo, pode-se conversar agora e interromper a conversa para retomar esse mesmo ponto em outro momento (amanhã, por exemplo), o que em tempo real não acontece. Pode-se conversar, ao mesmo tempo, com outras pessoas que estão em lugares diferentes. Pode-se falar do outro e com outros (como os posts que possibilitam texto e comentários com outros weblogs). Entretanto, lembro que a principal forma de comunicação é a linguagem escrita, embora seja constituída por nova forma de uso da língua, uma linguagem especial. Apesar dessas diferenças, posso afirmar que a aula ainda continua planejada e guiada, e o material didático faz um pouco esse papel. A ferramenta vira, guardada as devidas proporções, a sala de aula, o espaço denominador comum entre os participantes, governando também as escolhas de formas de interação e de possibilidades de uso dos diferentes tipos de atividades.

Com o objetivo de elucidar o que foi dito, trago exemplos extraídos de dois cursos que foram elaborados por mim e por participantes do grupo de pesquisa Gealin, sob minha coordenação: Curso ESPmed - leitura de abstracts para a área médica; Curso de Formação de Professores para a Abordagem Instrumental. Esses cursos foram desenhados em duas plataformas diferentes (pertencentes à Cogeae, da PUC-SP) e no Teleduc (pertencente à Unicamp).

Um dos primeiros passos, na aula virtual, é familiarizar-se com a plataforma e seus diferentes espaços. Por exemplo, observe as figuras 1 e 2 que ilustram as entradas para um curso: na Figura 1, as unidades são apresentadas no meio da tela, com possibilidade de se navegar para outras telas; na Figura 2, cada figura é uma unidade (que mostra o objetivo da unidade quando o mouse é colocado sobre ela). Ao clicar sobre ela, o aluno é conduzido a outro espaço (a unidade).

As figuras 3 e 4 , a seguir, ilustram como os conteúdos podem ser dispostos nas unidades para o aluno. Note que, na Figura 3, o conteúdo aparece como um texto longo, e, na Figura 4, o conteúdo é explicitado em partes. 


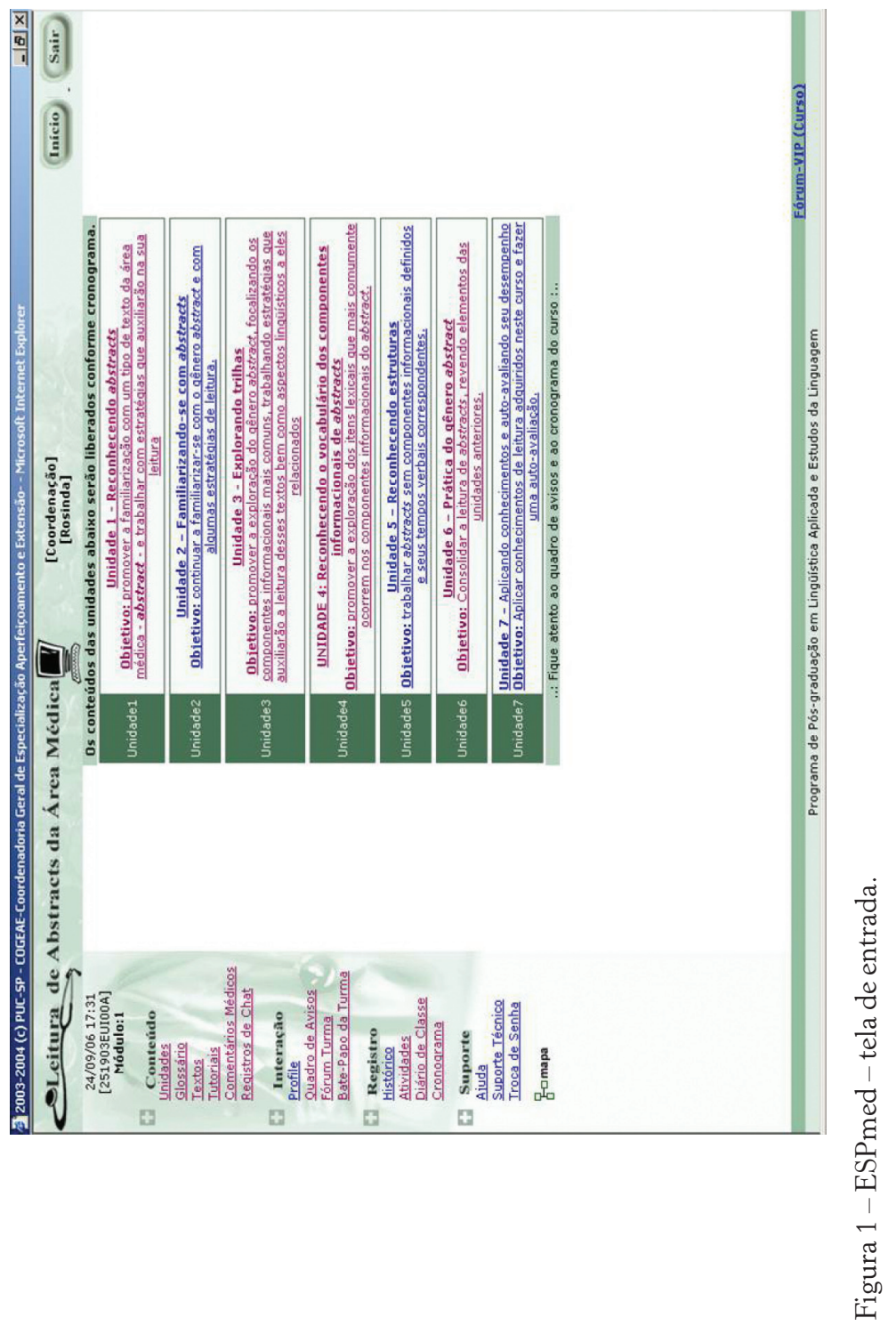


100 LINGUAGEM, EDUCAÇÃO E VIRTUALIDADE

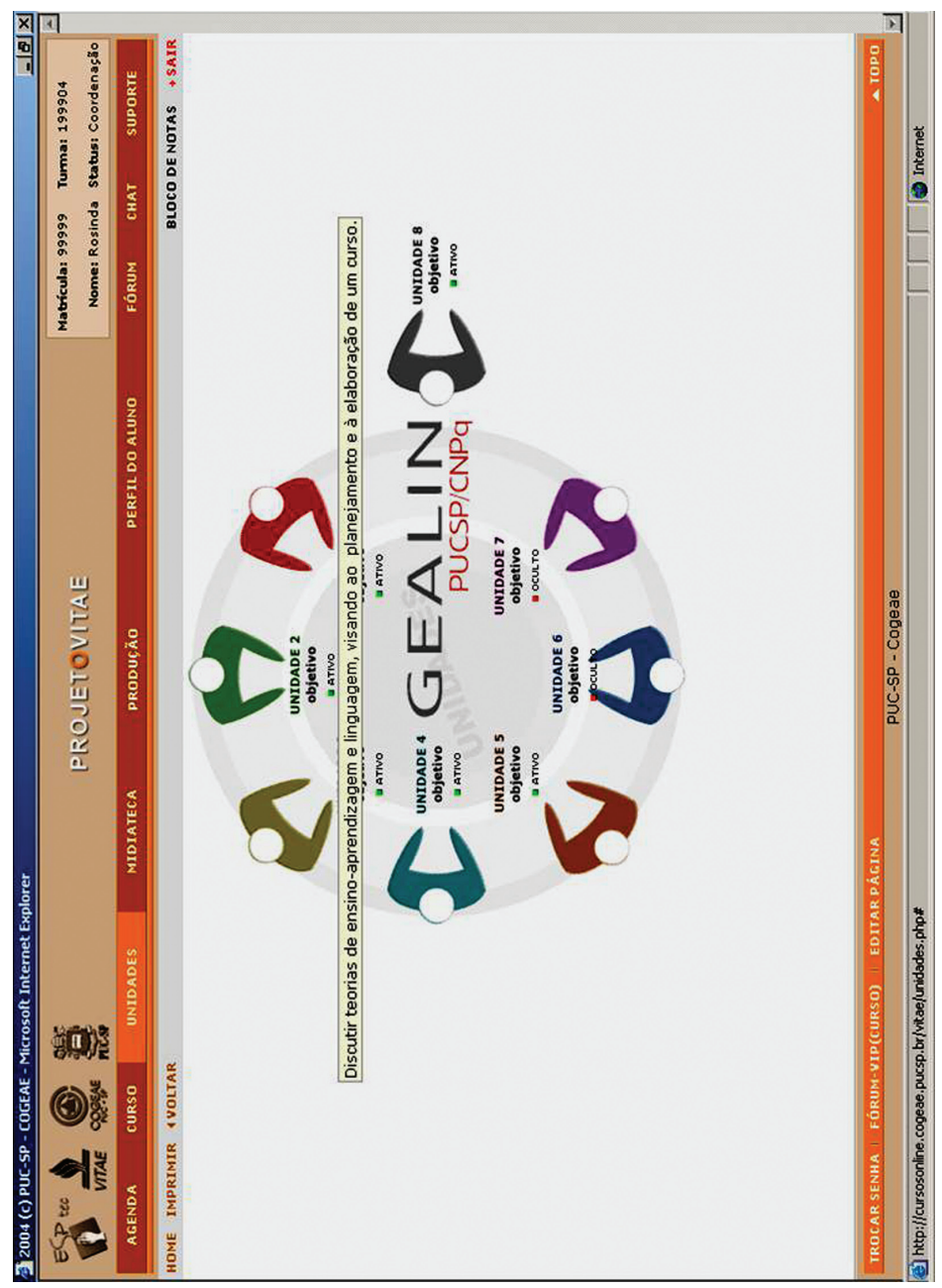

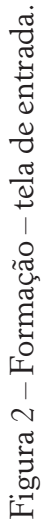


Outro aspecto, diferente do presencial, é a navegabilidade. Alguns programas possibilitam que o aluno tenha acesso a outro espaço clicando somente em um único lugar (um link), outros apresentam mais de um local para que se navegar (Figura 5). Há ainda aqueles, como o Teleduc, que obrigam o aluno a usar mais de uma tela para entrar no espaço desejado (Figura 6).

Além das áreas nas quais as unidades são disponibilizadas com seus conteúdos e atividades, as áreas de trabalho que cada plataforma (ferramenta) oferece, e que o designer decide utilizar, também colaboram para que o layout do material seja pensado de forma diferente, implicando escolhas de interação (nem sempre desejadas) possíveis. Pode-se escolher usar fóruns, chats e/ou correio eletrônico. A Figura 7 ilustra a página de entrada para os fóruns do curso de formação de professores.

Outra possibilidade de disponibilização de material (textos escritos, orais, visuais, etc.) para ser usado durante o curso, como base para o trabalho e/ou para servir de apoio, é a midiateca, ilustrada na Figura 8.

Pode-se ainda fazer uso de tutoriais (Figura 9) para guiar o trabalho de explicações linguísticas ou as que se fazem necessárias. Corresponderia, então, às exposições ou explanações que o professor costuma fazer nas aulas presenciais.

Outro aspecto que pontuo é a possibilidade de se ter a mesma variedade tipológica de atividades encontrada na aula presencial: perguntas e respostas fechadas ou abertas, com ou sem justificativas, verdadeiro/falso, múltipla escolha, combinação de alternativas, criação de glossários pelo aluno, entre outras. Um pouco diferente do que na presencial é a construção de tarefas que se realizam em mais de um espaço (área de atividades, fórum, chat, etc.) e conduzem o aluno a interagir de várias formas (com material, par, grupo), conforme ilustra a Figura 10.

Finalmente, ofeedback (Figura 11) que pode se realizar automaticamente, com respostas únicas ou opções, ou como uma explicação que retoma o que foi aprendido e como foi aprendido, fornece uma avaliação do desempenho dos alunos. 


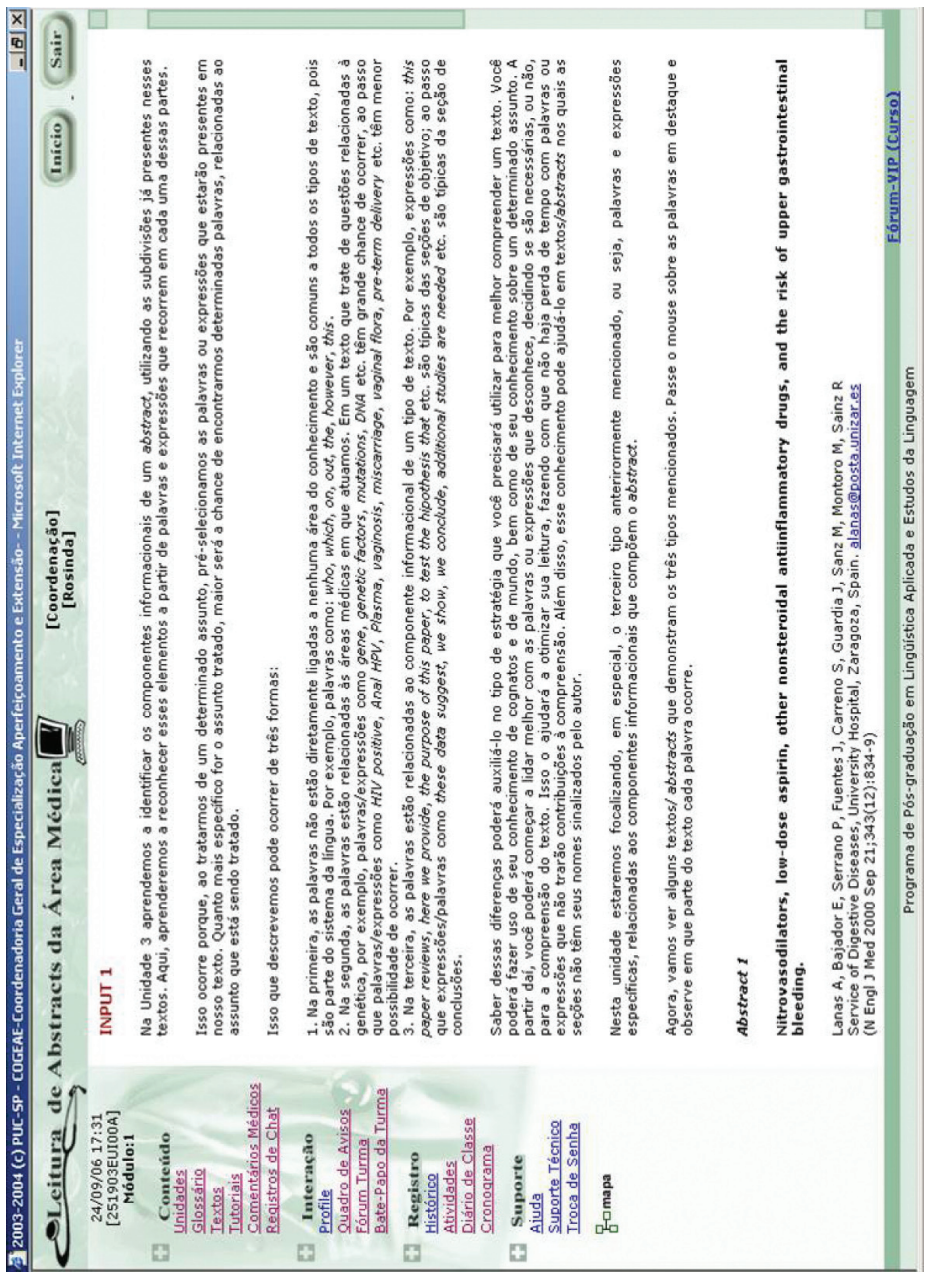

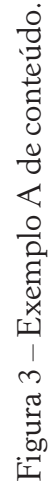




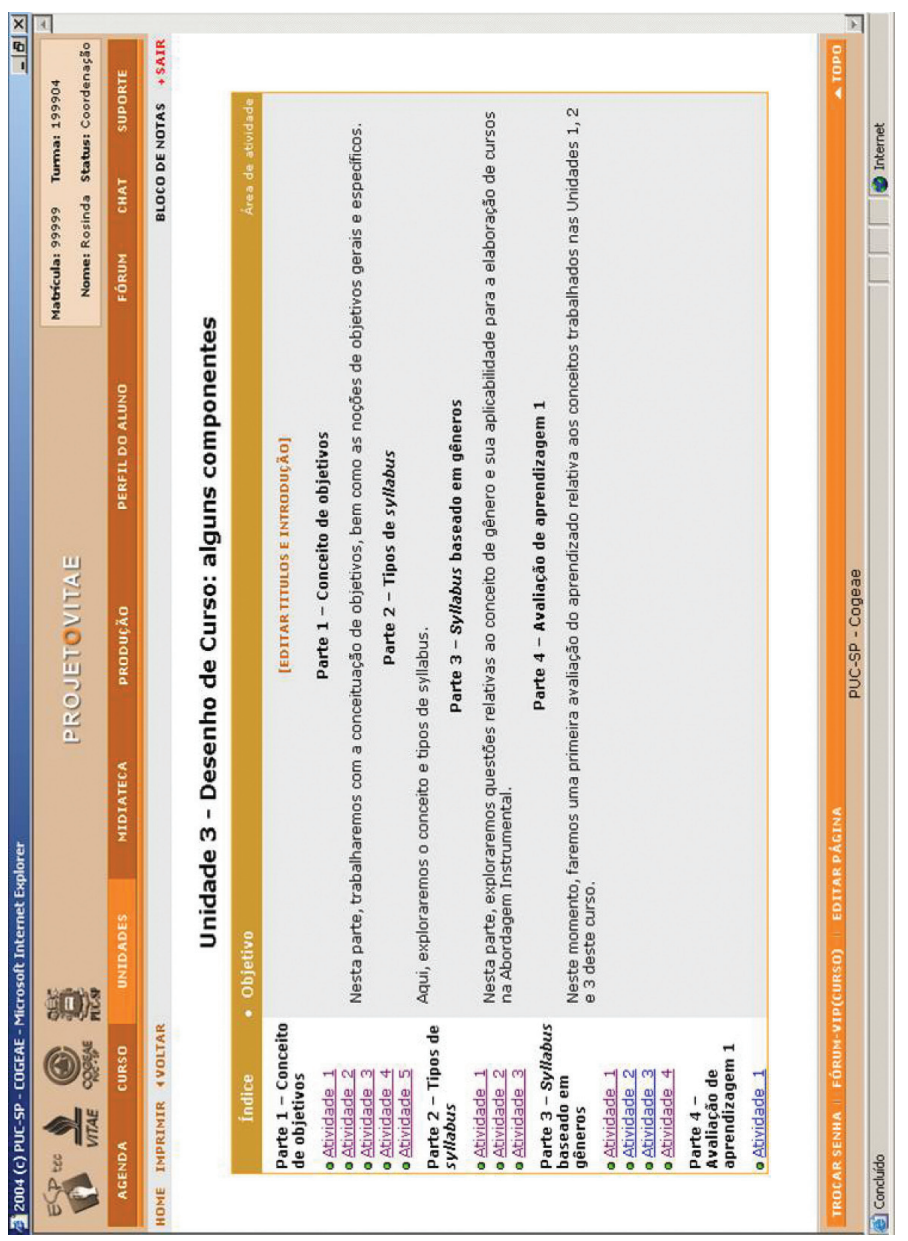

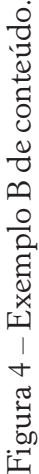


104 LINGUAGEM, EDUCAÇÃO E VIRTUALIDADE

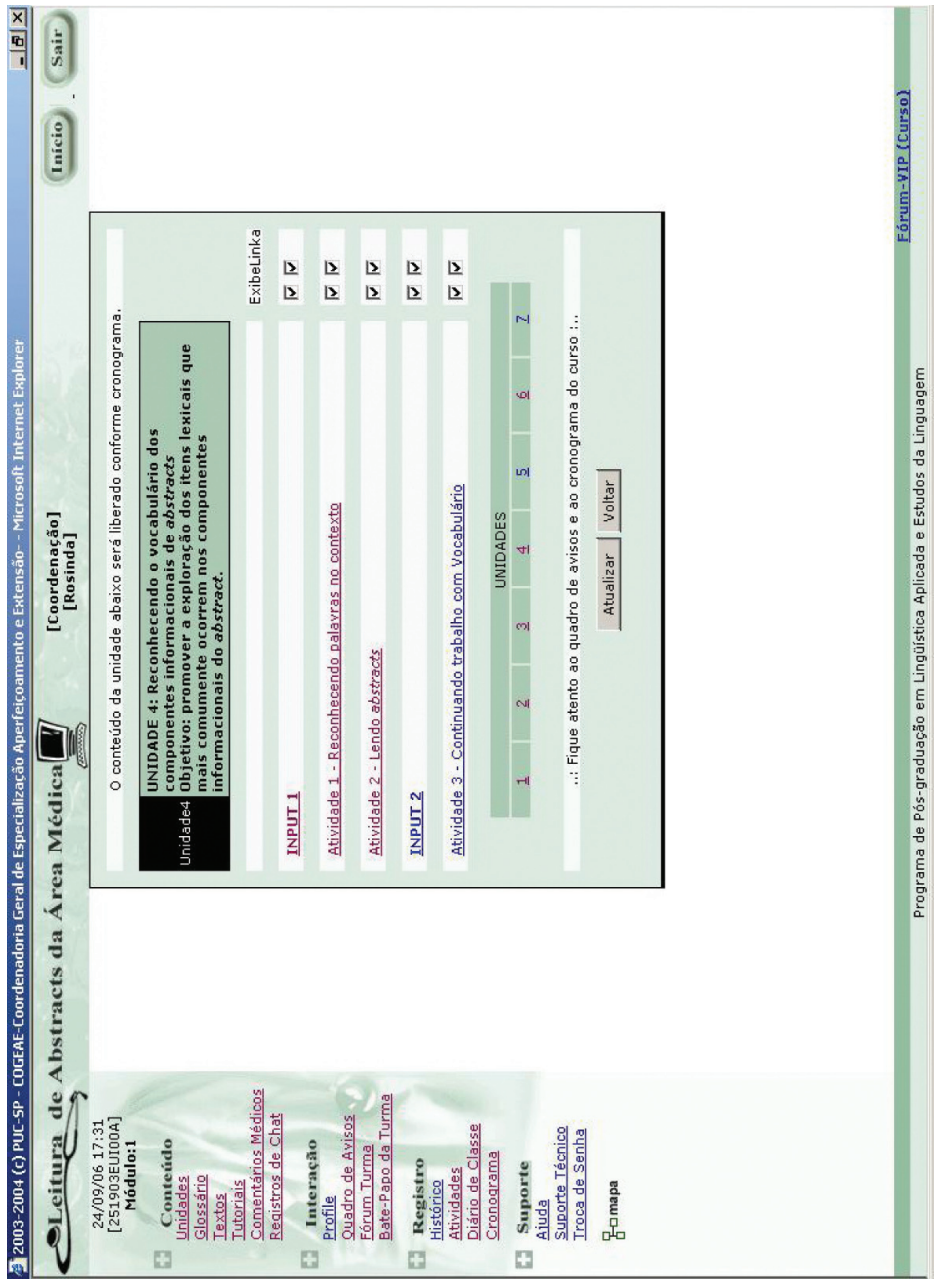

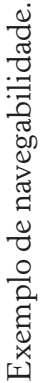




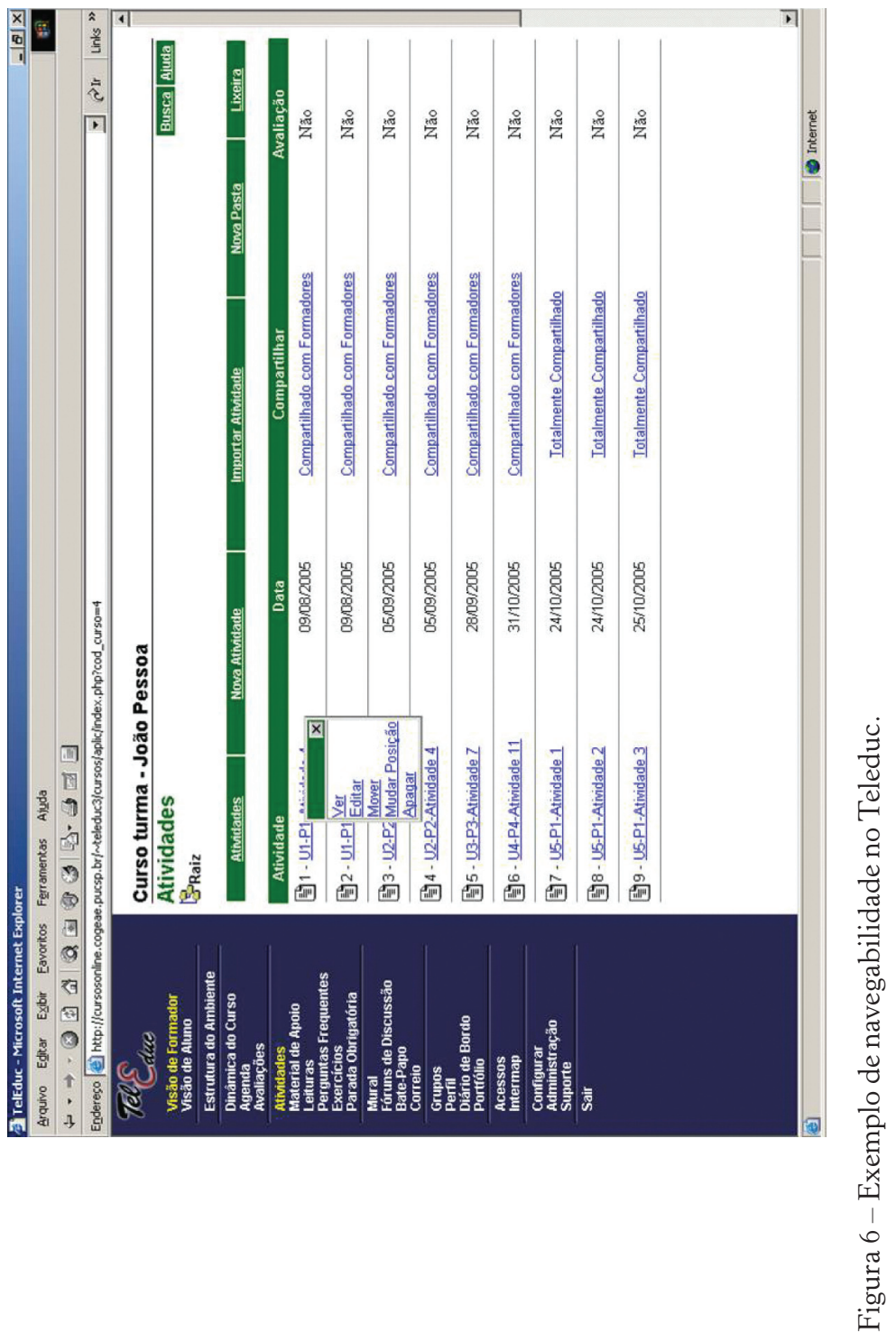




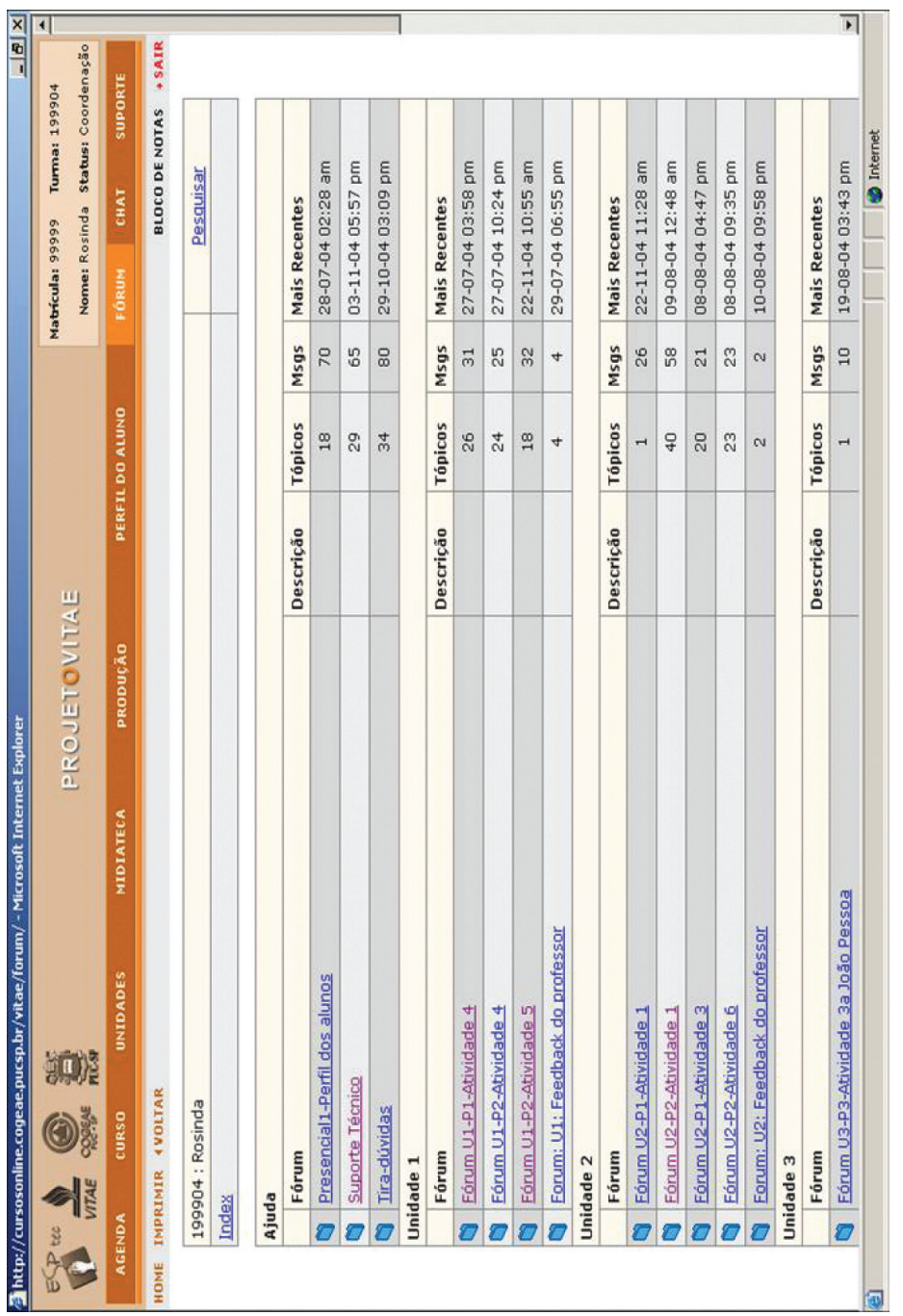

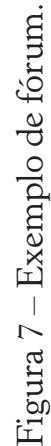




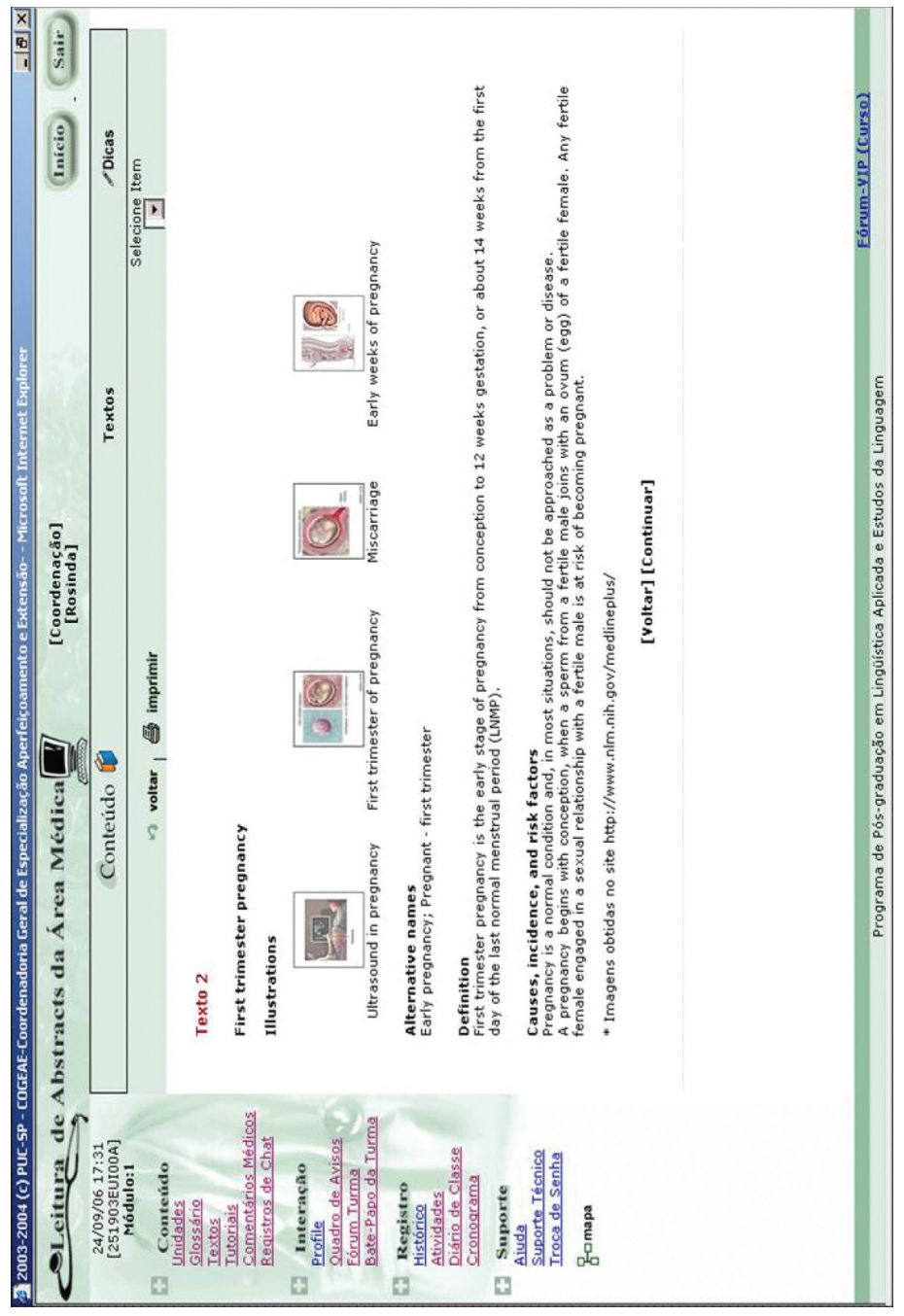

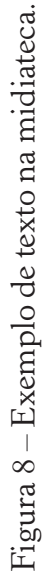




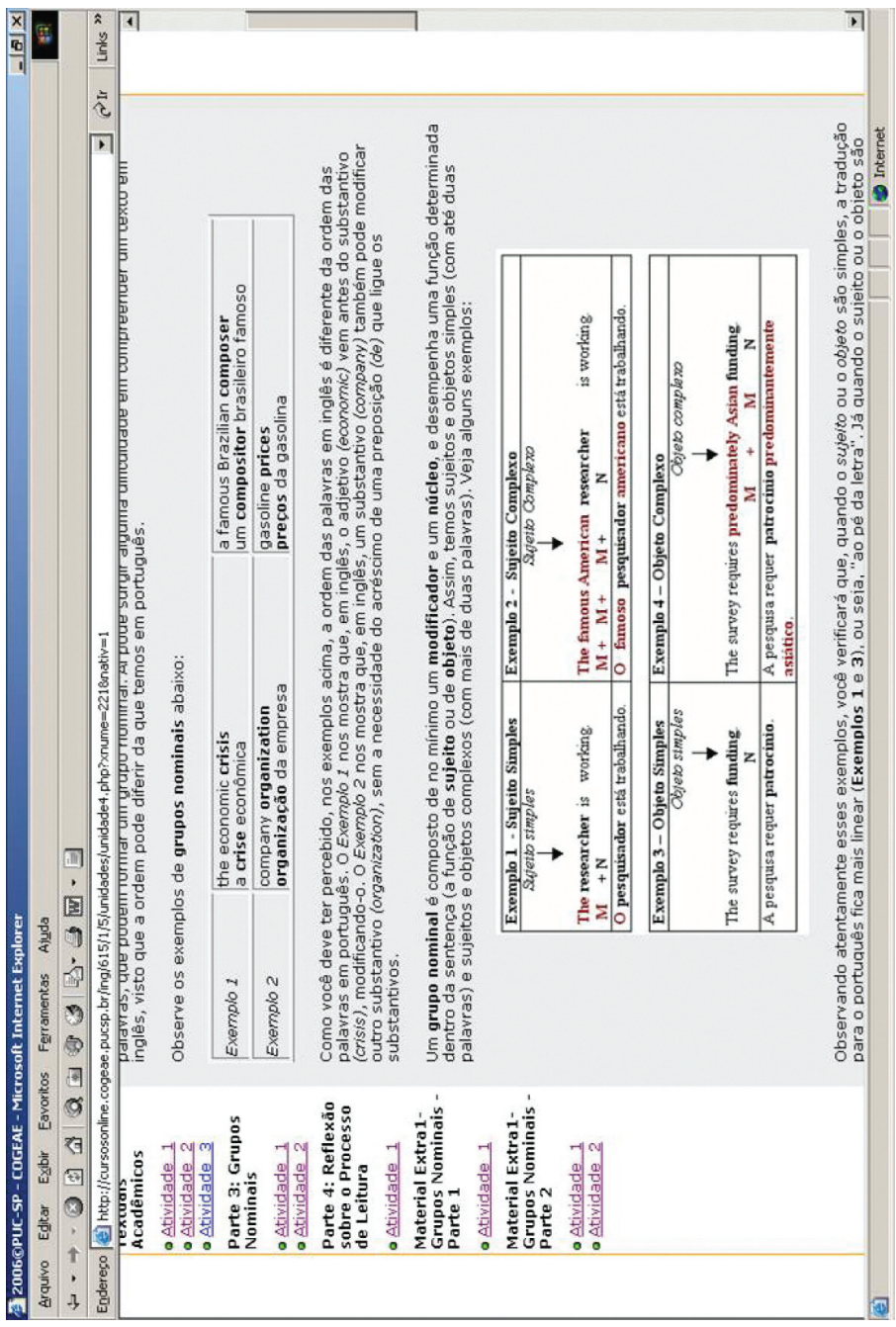

䓪 


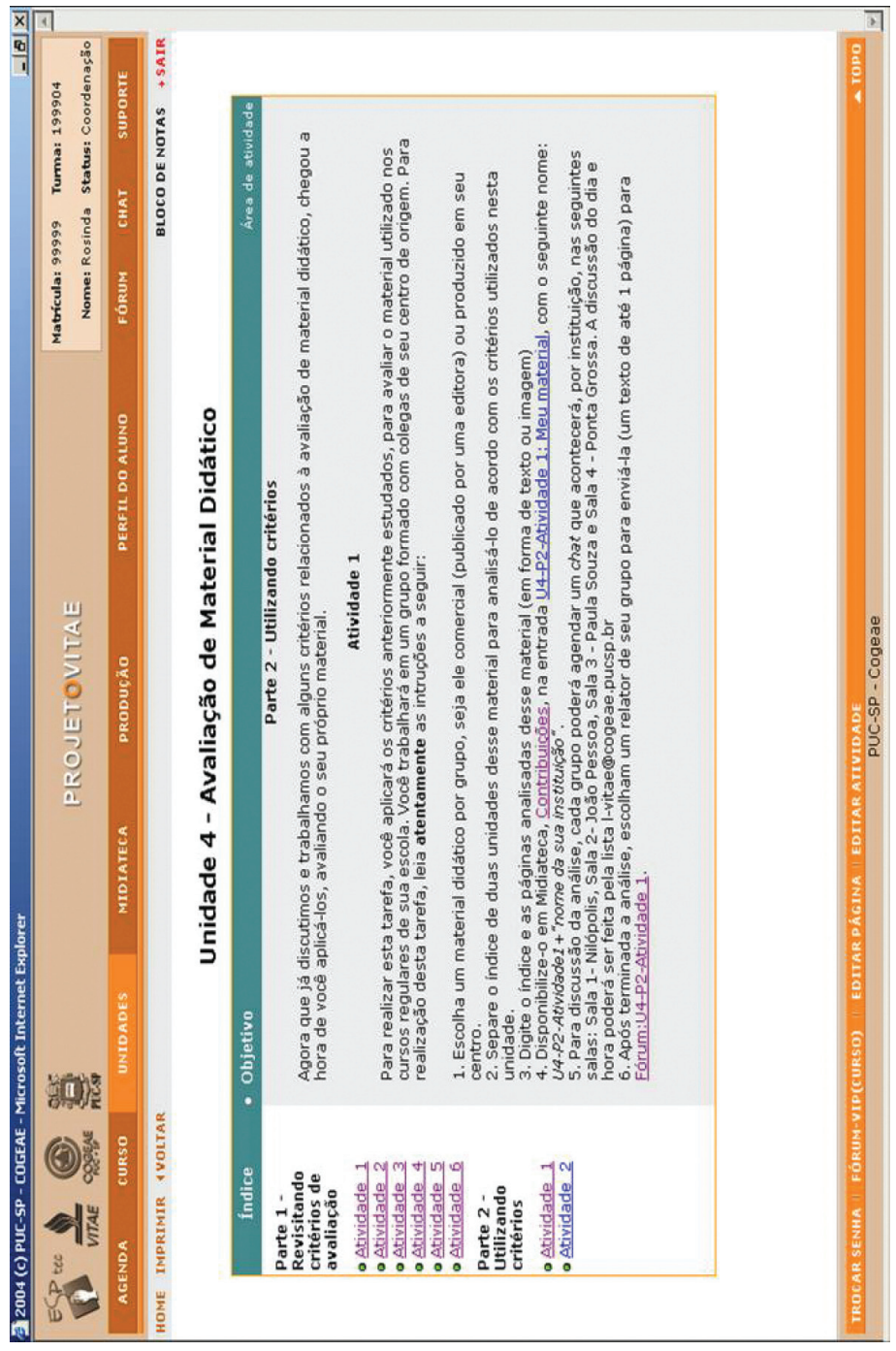

0
0
0
0
0
0
0
0
0
0
0
0
0
0
0
0
0
0
0
0
0
0
0
0 


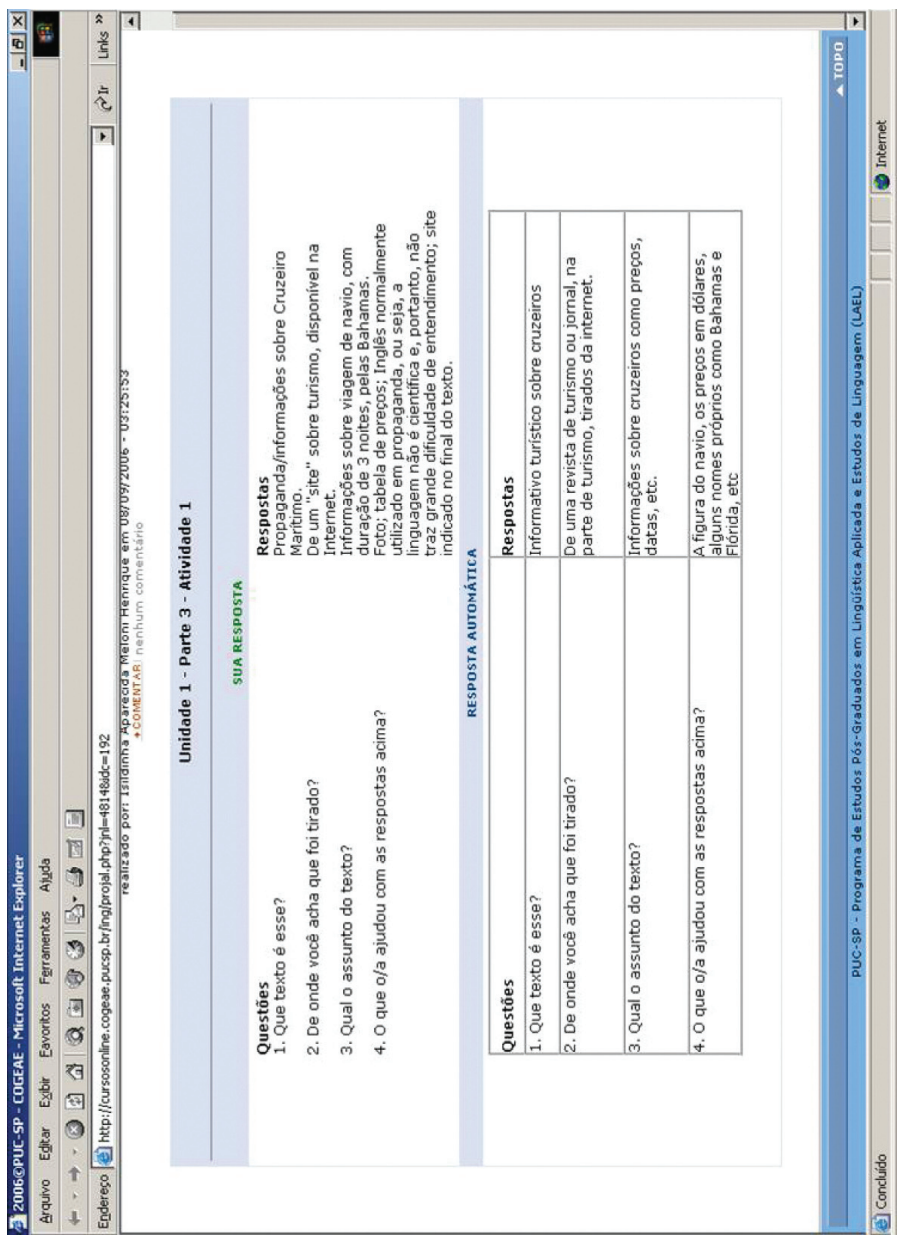


Retomo a pergunta: o que envolve pensar o material para o ambiente digital? Com o mostrado anteriormente, pode-se concluir que o que se fez e vem se fazendo nas últimas décadas, em relação às formas de ensinar e aprender língua inglesa, mesmo com algumas diferenças, não chega a mostrar mudanças radicais e estupendas que as façam irreconhecíveis em relação ao que se faz na aula presencial. Discuto esse aspecto a seguir.

\section{Ponderações e desafios}

Gostaria de fazer algumas considerações a respeito do design de materiais on-line para que se entenda o que é compartilhado com o presencial, o que se faz, ou não, de diferente e, principalmente, o que acredito que precise ser feito para o material ficar mais e mais em sintonia com as possibilidades oferecidas pelas TICs.

Comento, inicialmente, alguns pontos relativos à tipologia de atividades, aos tipos de interação e suas implicações na escolha da ferramenta, para refletir sobre o que é compartilhado e o que se pode pensar para fazer a diferença.

Sobre a tipologia de atividades, o primeiro questionamento refere-se a quais usar. As mais tradicionais (como perguntas e respostas, verdadeiro ou falso) ou o uso de tarefas comunicativas $(\mathrm{Nu}$ nan, 2004) e projetos (Hernández \& Ventura, 1998)? Juntamente com essa questão, deve-se pensar no grau de autonomia e previsibilidade que se quer dar às atividades, bem como graus de dificuldade que podem ir desde dificuldades cognitivas até linguísticas. Esses aspectos são importantíssimos, quando se desenha material para o ensino de línguas. As implicações de se escolher uma ferramenta (um programa de autoria, um site livre) imbricam em modos de se pensar como as atividades serão feitas, onde serão feitas, onde aparecerão. Outro aspecto a considerar é com quem elas serão feitas e como será o feedback. Nesse sentido, é preciso que se considere também o quanto elas serão diferentes das presenciais.

Quanto às interações (Moore,1989), podemos ter aluno-material, aluno-professor, alunos-alunos, alunos-alunos-material-pro- 
fessor. Entretanto, gostaria de trazer duas que normalmente não são comentadas: aluno-material externo e alunos-outros.

Bem comum tem sido usar o material elaborado para o aluno internamente. Contudo, fazer o estudante explorar os limites que saem do "espaço" em que estuda não é muito comum. Fazer isso acontecer em um curso de línguas implica aumentar o número de atribuições do designer, como planejar a maneira que o aluno trará uma informação para o ambiente de aprendizagem, ou mesmo como indicará onde encontrou certo material. As tarefas do professor também aumentam, já que ele se verá obrigado a trabalhar com uma carga bem maior, porquanto, provavelmente, cada aluno trará diferentes informações que o docente deverá analisar e enviar feedback para todos os estudantes. Além disso, é arriscado, pois coloca conhecimentos à prova. Esse aspecto, na minha opinião, é um dos grandes desafios para o futuro.

A segunda interação alunos-outros também é um desafio. Implica fazer os alunos trabalharem com participantes externos ao seu ambiente de aprendizagem e isso, com certeza, acarreta mudanças nas formas de planejar o feedback e quais ações o professor precisa realizar para acompanhar o andamento do curso (se é que será sempre possível).

Outro desafio para o design de materiais é o aproveitamento das TICs para o desenvolvimento de trabalhos de aprendizagem que possam utilizar sites e mecanismos de busca, e-groups, keypals, e-mails, blogs e chats que possibilitem ao aprendiz de língua estrangeira ter contato direto com o mundo real, abrindo, portanto, possibilidades de novas formas de ensinar e aprender. Ou ainda a possibilidade de se formar comunidades de aprendizagem e/ou virtuais que passem a operar independentemente do "tempo" do curso.

Além disso, o design de materiais e cursos de línguas precisa lidar com o desenvolvimento da produção oral, primordial em muitas situações específicas de aprendizagem de língua estrangeira. Isso não quer dizer que não demos os passos iniciais para vencer esse desafio. 
Hoje, contamos, por exemplo, com o MSN ou Skype, mas os esforços ainda se mostram incipientes para essa demanda premente.

Trago, antes de finalizar, uma questão em bastante evidência hoje: os chamados objetos de aprendizagem definidos, que Araújo Jr. e Marquesi (2008, p.358) conceituaram "como qualquer entidade digital ou não, que possa ser usada para aprendizagem, educação ou treinamento". Os autores complementam que algumas das vantagens de se usar esses objetos de aprendizagem é que eles são reutilizáveis em aulas virtuais, possibilitam ao professor modelar uma aula ou um determinado conteúdo por meio de diversas formas de visualização e de usos de mídias diferentes. Esse é um item que pouco foi explorado em aulas de língua estrangeira, mas que precisa ser investigado e explorado, uma vez que promete usar as potencialidades dos recursos multimidiáticos para colaborar com a aprendizagem.

Por fim, creio que é inegável o fato de estarmos frente a grandes mudanças nas formas de ensinar e aprender, mas que, no meu entender, ainda não aconteceram. As novas tecnologias, indiscutivelmente, demandam nova pedagogia e/ou andragogia (Almeida, 2008). Acredito que ainda estamos engatinhando no que se refere à utilização das potencialidades que a internet oferece ao campo educacional. Com certeza, novas formas de ensinar e aprender precisam ser elaboradas e pensadas à luz das ferramentas disponíveis que ainda não são utilizadas pelos designers em sua total capacidade de gerar, talvez, o que venha a se constituir em "ciberaprendizagem".

\section{Bibliografia}

ALMEIDA, M. E. B. As teorias principais da andragogia e heutagogia. In: LITTO, F.; FORMIGA, M. (Ed.). Educação a distância: o estado da arte. São Paulo: Pearson Education do Brasil, p.105-11, 2008.

ARAÚJO JR., C. F.; MARQUESI, S. C. Atividades em ambientes virtuais de aprendizagem: parâmetros de qualidade. In: 
LITTO, F.; FORMIGA, M. (Ed.). Educação a distância: o estado da arte. São Paulo: Pearson Education do Brasil, p.358-68, 2008.

DAMIANOVIC, M. C. (Org.). Material didático: elaboração e avaliação. Taubaté: Cabral, 2007.

DUDLEY-EVANS, T.; ST. JOHN, M. J. Developments in English for specific purposes: a multi-disciplinary approach. Nova York: Cambridge University Press, 1998.

ELLIS, R. Task-based language learning and teaching. Oxford: Oxford University Press, 2003.

FILATRO, A. Design instrucional na prática. São Paulo: Pearson Education do Brasil, 2008.

GRAVES, K. Designing language courses: a guide for teachers. Boston: Heinle \& Heinle, 2000.

HERNÁNDEZ, F.; VENTURA, F. J. A organização do currículo por projetos de trabalho: o conhecimento é um caleidoscópio. São Paulo: Artes Médicas,1998.

HUTCHINSON, T.; WATERS, A. English for specific purposes: a learning-centred approach. Cambridge: Cambridge University Press, 1987.

JONASSEN, D. H. (Ed.). Handbook of research for educational communications and technology. Nova York: Macmillan Library Reference USA, 1996.

MAIA, C. (Org.). Ead.br. Educação a distância no Brasil na era da internet. São Paulo: Editora Anhembi Morumbi, 2000.

MOORE, M. G. Three types of interaction. The American Journal of Distance Education, v.3, n.2, p.1-6, 1989.

NISKIER, A. Educação a distância: a tecnologia da esperança. São Paulo: Loyola, 1999.

NUNAN, D. Designing tasks for the communicative classroom. Cambridge: Cambridge University Press, 1989.

RAMOS, R. C. G.; FREIRE, M. M. Curso de leitura via rede: da preparação à conscientização. In: COLLINS, H.; FERREIRA, A. O. (Org.). Relatos de experiência de ensino e aprendizagem de 
línguas na internet. Campinas: Mercado de Letras, p.279-96, 2004.

TOMLINSON, B. Materials development in language teaching. Cambridge: Cambridge University Press, 1998. . Materials development. In: CARTER, R.; NUNAN, D. (Eds.). The Cambridge guide to teaching English for speakers ofother languages. Cambridge: Cambridge University Press, p.66-71, 2001.

. Developing Materials for Language Teaching. Londres: Continuum, 2003.

WARSCHAUER, M.; HEALEY, D. Computers and language learning: an overview. Language Teaching, v.31, p.57-71, 1998. 



\title{
ConCEPÇÃO, DESIGN \\ E FERRAMENTAS DE UM \\ AMBIENTE VIRTUAL COLABORATIVO DE ENSINO-APRENDIZAGEM DE LÍNGUA ESPANHOLA
}

\author{
Ucy Soto \\ UNESP, FCL - Araraquara \\ Isadora Valencise Gregolin \\ Universidade Federal de São Carlos \\ Marcelo Rangel \\ PROLEM, Universidade Federal Fluminense
}

Existem outros mundos, mas eles estão neste.

Frase atribuída a Orwell

No contexto de ensino-aprendizagem de línguas é possível observar, nos últimos anos, uma tendência de inserção de ferramentas tecnológicas - principalmente a integração de recursos oferecidos pela internet - ao cotidiano do ensino, seja ele a distância ou presencial. No entanto, para que um ambiente virtual de ensino-aprendizagem possa funcionar de forma a favorecer maior interação entre alunos e entre aluno(s) e professor(es) e intitular-se como um ambiente colaborativo, não basta definir um layout atraente e amigável e disponibilizar nele as ferramentas mais modernas do momento. Incorporar novas tecnologias ao processo de ensinar e aprender, sem repetir um déjà-vu da ferramenta pela ferramenta implica, necessariamente, repensar vários aspectos que vão da questão do trabalho docente nessa "Idade Mídia" (ver Mill \& Ferreira, neste livro) a aspectos de desenho de materiais instrucionais propria- 
mente ditos (ver Ramos, também neste livro), passando por uma infinidade de outros fatores que, todos eles juntos, num futuro não muito distante, definirão o que realmente faremos com todo esse potencial tecnológico que parece estar cada vez mais disponível a um maior número de pessoas.

Se acreditarmos, como García Carrasco (s/d.), que o ensino não é nem deve ser alheio às possibilidades que as denominadas novas tecnologias abrem e que a combinação dos serviços da web com as capacidades de hipermídias e multimídias deve ser canalizada por intermédio de interfaces adequadas, capazes de suportar toda essa potência formativa, sem dominar o processo ou fazer o aluno se sentir perdido, então, a análise do que efetivamente acontece em sala de aula, em que o professor procura trabalhar adotando uma metodologia que contemple o virtual, pode muito contribuir para que compreendamos como encaminhar e integrar atividades formativas nesse novo contexto.

Nessa tentativa de melhor compreendermos como o mundo virtual afeta professores e alunos brasileiros de espanhol, criamos, em 2007, o curso Español para turismo, ${ }^{1}$ doravante EPT. Desde sua concepção, o EPT buscou refletir a imbricação existente entre ferramentas, atividades e linguagens que se unem de modo singular em um ambiente virtual, sejam elas utilizadas na modalidade blended learning, em uma sala de aula que une o presencial ao virtual, seja como ambiente exclusivo, em cursos de educação a distância.

No presente trabalho, gostaríamos de apresentar o resultado parcial de um dos aspectos envolvidos na mise en écran de um curso voltado para o ensino-aprendizagem de uma língua singularmente estrangeira (Celada, 2002) para nós brasileiros, o espanhol. Referimo-nos à nossa experiência com o design e a maneira como ferramentas e recursos podem ser articulados na montagem de um curso de ensino de espanhol sem concebermos a organização do conheci-

1 Em nenhum momento pretendemos que o EPT seja um modelo a ser seguido. Pareceu-nos, somente, que iniciar a discussão com um caso concreto pode contribuir para vislumbrarmos possibilidades e, por que não, limitações. 
mento ou da própria língua de forma linear. Embora se trate de um curso de nível intermediário, para alunos que já possuam conhecimento básico da língua espanhola, essa mesma metodologia vem sendo replicada com alunos de cursos iniciantes. Por questões de tempo/espaço não trataremos aqui das interações nem do trabalho de mediação que foi realizado durante a implementação do curso, mas, sempre que se fizer necessário, aludiremos a alguns dos resultados das análises que estão em andamento.

\section{O design do curso EPT}

O EPT foi pensado, desde o início, para ser um curso de língua espanhola voltado para brasileiros. Apresentaremos o primeiro módulo de uma série ${ }^{2}$ de cursos planejados para serem ministrados em uma plataforma de ensino-aprendizagem on-line, com no mínimo quarenta horas de trabalho, a ser realizado em atividades síncronas e assíncronas pelos alunos, durante quatro meses (esse é o desenho final, depois das reformulações elaboradas a partir da avaliação de professores e alunos participantes). O curso utiliza a plataforma virtual livre Moodle, que foi desenvolvida a partir dos princípios do construtivismo social para potencializar o aprendizado em colaboração e permitir a incorporação de diversos tipos de atividades e ferramentas, como exercícios interativos em Hot- potatoes, arquivos de vídeos, áudios e/ou infografias, acesso a links de sites dentro e fora do ambiente, glossários, wikis e ferramentas de comunicação incorporadas como chats escritos ou fóruns (ver mais detalhes sobre Moodle em Rostas \& Rostas, neste livro).

O curso está dividido em seis seções (ver Figura 1). A estruturação de cada uma delas se funda em postulados socioconstrutivistas

2 Apresentaremos neste trabalho o módulo 1 (EPT-M1), que teve a Espanha como destino turístico selecionado. Módulos subsequentes estão programados para incentivar uma viagem por toda a geografia linguístico-cultural do mundo hispânico. Nessa viagem, enfatizamos a relação eu-outro tanto interna como externamente ao curso, entre um eu brasileiro, que fala português, e um outro hispânico, que fala uma das variedades da língua espanhola. O EPT-M2 terá o Chile como destino. 
de ensino-aprendizagem (Piaget, 1996, e Vigotsky, 2001) e visam promover aprendizado a partir:

- da busca de soluções a problemas ou questionamentos;

- da interação com os colegas, com as atividades e também com terceiros (que não fazem parte do quadro de alunos ou docente(s) do curso);

- da (re)elaboração e uso dos conhecimentos que cada um possui individual e coletivamente.

O EPT busca centrar-se no aluno como parte de um grupo e tem como um dos objetivos fomentar o trabalho colaborativo e a autonomia dos estudantes em relação ao professor, que já não deve ser visto como o provedor de todas as informações e o saneador de todas as dúvidas. ${ }^{3}$ No curso, a interação entre os alunos é entendida como um dos grandes potencializadores da aprendizagem (Johnson, Johnson \& Holubec, 1999) e como eixo do caminho a ser trilhado.

O trabalho colaborativo se desenvolve em pequenos grupos e é o componente estruturador das principais atividades de ensino-aprendizagem. O curso não está centrado no aprendizado linguístico puro e duro da língua-estrutura, mas visa à apropriação de elementos discursivos que permitam que o aluno "funcione" servindo-se da língua-alvo. Propõe-se muito mais do que o desenvolvimento de conhecimentos e habilidades individuais, busca-se o desenvolvimento de uma atitude positiva em relação à interdependência e respeito às contribuições dos companheiros na realização de uma tarefa. Assim, a língua é um dos componentes importantes não só na resolução da tarefa, mas também o meio pelo qual os alunos se comunicam entre si e com os demais envolvidos no processo de ensino-aprendizagem. Para alcançar tal objetivo, o desenho do curso foi elaborado para possibilitar a construção de conhecimento em colaboração, com a oferta de atividades que, seguindo Pérez Torres (2006, p.109):

3 Essa mudança do papel desempenhado pelo professor não se dá sem uma boa dose de estresse por parte dos alunos e, também, do docente. Toda mudança implica certo grau de atrito e negociação por parte dos envolvidos no processo. 
foment[an] la construcción del conocimiento mediante la interacción con el medio y los otros individuos [...] e permit[en] una inmersión en contextos significativos que plante[an] tareas que necesit[an] de la reflexión para la resolución de las mismas.

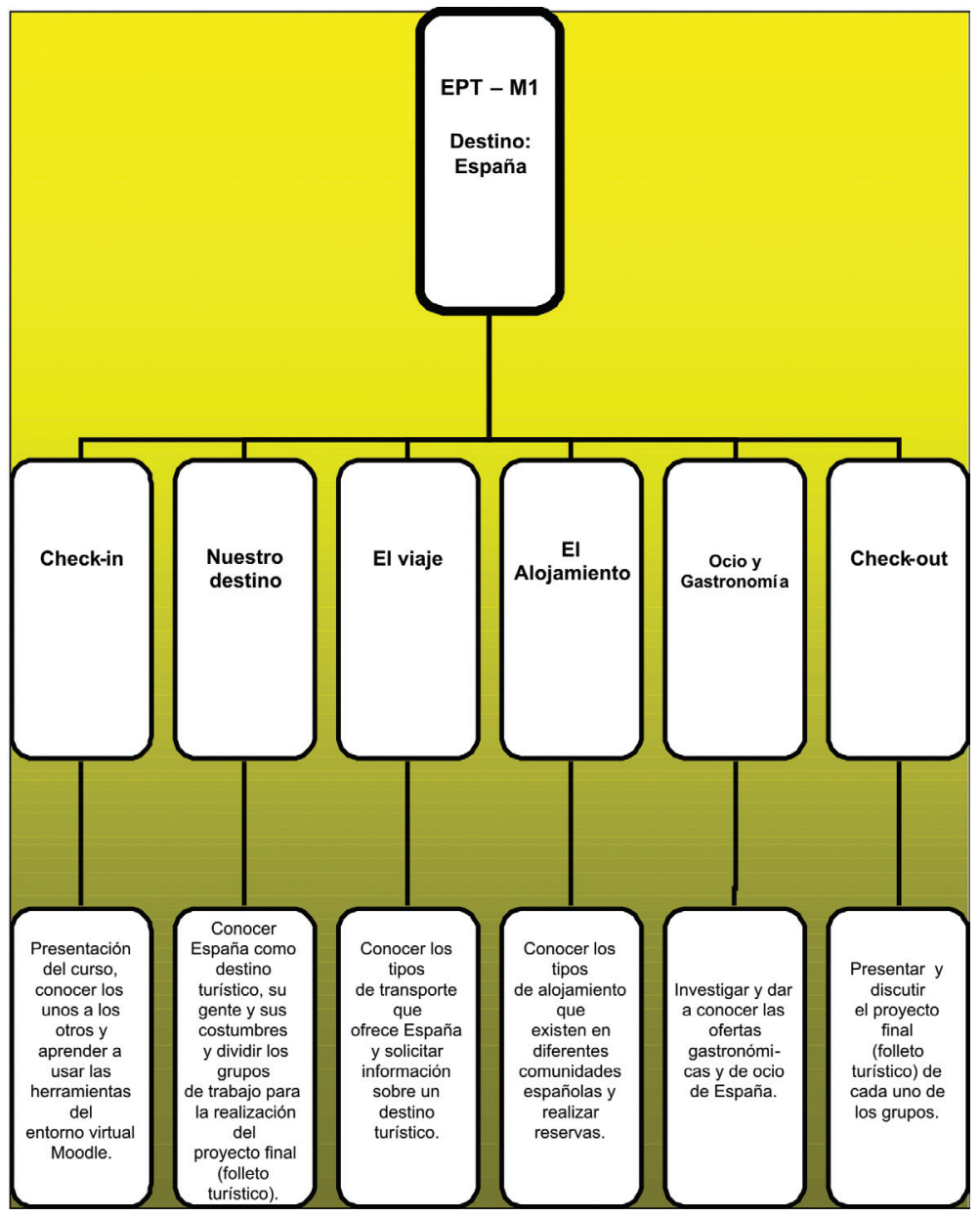

Figura 1 - Estrutura do curso Español para turismo, módulo 1 EPT-M1). 
Sua estruturação segue uma metodologia que se centra na realização conjunta de uma tarefa (baseamo-nos em Estaire, 1999, e García Santa-Cecilia, 1999). A realização das tarefas do curso leva a prática em sala de aula a situações reais. Por exemplo, uma das atividades propostas aos alunos consiste na elaboração de um roteiro de viagem. Para preparar essa tarefa, os alunos têm de selecionar e organizar vários tipos de informações (hospedagem, lazer, comida, etc.), que devem, inevitavelmente, ser obtidas de agências de viagem reais. Instala-se, portanto, necessidade real de comunicação na língua estrangeira: para obter a informação é preciso que se busque uma agência de turismo espanhola e se escreva a ela, na língua estrangeira, compartilhando, em seguida, a resposta com os companheiros no chat ou em um tópico do fórum. Assim, exige-se a responsabilidade dos alunos sobre seu processo de aprendizagem, implicando mudanças profundas nas funções de professor e de aluno. Insistimos que, no desenho do curso, propiciam-se variados espaços de discussão e intercâmbio de ideias que possam constituir uma comunidade de aprendizagem baseada no trabalho em equipe, na integração de conhecimentos e na resolução de problemas por meio da língua estudada. Mas isso nem sempre acontece, pois é necessário muito trabalho por parte de todos os membros do grupo. ${ }^{4}$

\section{Estrutura e recursos selecionados para o primeiro módulo}

Trabalhando com a estrutura oferecida pelo Moodle e sua flexibilidade quanto à disposição dos elementos, aproveitamos a divisão em três colunas típicas da plataforma para delimitar os espaços através da definição de três áreas (ver Figura 2):

- Espaço de gestão: coluna fixa na parte esquerda da tela, destinada a apresentar o perfil de todos os participantes do

4 Nas quatro turmas de EPT implementadas em 2007, houve casos de fracasso, mas também houve muitos casos em que, apesar dos problemas iniciais, os grupos se reorganizaram e conseguiram realizar o projeto final do curso, que será explicitado mais adiante. 


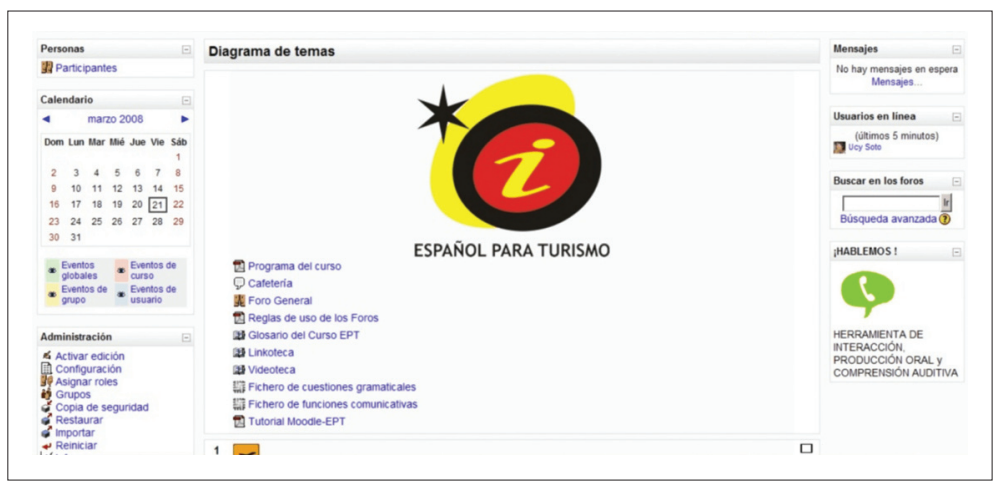

Figura 2 - A tela de abertura do curso.

grupo, a gestão das tarefas e seus prazos e a gestão de aspectos administrativos, tais como notas.

- Ferramentas de comunicação: coluna vertical fixa na parte direita da tela, destinada à comunicação entre os usuários - mensagens, visualização dos participantes que estejam conectados, ferramenta de busca por palavras-chave nos fóruns do curso e ferramenta de comunicação oral (Hablemos).

- Recursos permanentes e unidades didáticas: coluna central.

Na coluna central há uma seção fixa (sempre disponível) e outras que mudam conforme o andamento do curso (aproximadamente a cada duas semanas). Na seção fixa, estão os recursos que ficam disponíveis aos alunos durante todo o curso (ver Figura 2), que são:

- O programa do curso.

- A cafeteria: ferramenta de chat disponível para os encontros em tempo real entre os alunos e entre alunos e professor.

- O fórum geral: eixo central no desenvolvimento do curso, organizador das discussões, dúvidas, comunicações assíncronas. Sempre aberto a todos os participantes do curso.

- As regras de uso dos fóruns. 
- O glossário: dicionário interativo de termos-chave da área do turismo e de uso geral da língua espanhola. Os alunos podem adicionar novos termos ao longo do curso.

- A linkoteca: links de interesse para o curso - dicionários, gramáticas, etc. Os alunos também adicionam links novos segundo seu interesse.

- A videoteca: endereços virtuais de vídeos da área de turismo e de questões culturais.

- O fichário de questões gramaticais: explicações gramaticais e exemplos.

- O fichário de questões comunicativas: expressões e estruturas linguísticas mais relevantes para a comunicação em espanhol para turismo.

Nas seções que mudam, há seis tópicos distintos (ver também Figura 1) que apresentam conteúdos específicos do espanhol para turismo, foco da tarefa em questão. Cada seção se organiza visualmente de forma bastante parecida, porém apresenta atividades e tarefas diferentes que ajudarão na elaboração do projeto de fim de curso. As seis seções ou tópicos do curso são:

$\checkmark$ Check-in

$\checkmark$ Nuestro destino

$\checkmark$ El viaje

$\checkmark$ El alojamiento

$\checkmark$ El ocio y la gastronomía

$\checkmark$ Check-out

$\mathrm{Na}$ Figura 3 apresentamos a estrutura geral do tópico 1, Check-in, que prepara o aluno para o aprendizado colaborativo on-line em grupo e também funciona como introdução ao ambiente de aprendizagem virtual.

Na primeira seção - apresentação do curso, dos usuários e do próprio ambiente de estudo -, são trabalhadas várias habilidades a partir de diferentes atividades: ${ }^{5}$

5 Cada uma das atividades elencadas já está linkada. Siga o link, entre na FCL-Virtual como VISITANTE, clique em EXTENSÃO. Caso não consiga acessar as ativi- 
1

\section{Check-in (semana 1)}

Nuestros objetivos esta primera semana son: presentarnos, conocernos los unos a los otros y aprender a usar las herramientas de nuestro entorno virtual.

Parece poco pero esta fase inicial es muy importante. No dudes en ningún momento en entrar en el Foro General para pedir cualquier tipo de explicación o hacer comentarios.

La tarea de la semana será la actualización de tu perfil de participante.

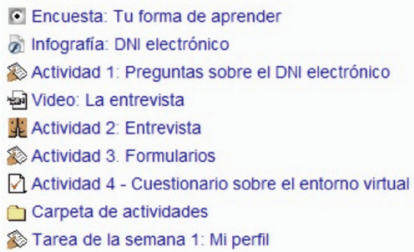

Figura 3 - Seção 1 do curso.

a) Autoconhecimento/conhecimento do ambiente virtual: "Encuesta: Tu forma de aprender", questionário de múltipla escolha com objetivo de avaliar as atitudes com relação ao aprendizado; "Actividad 4: Cuestionario sobre el entorno virtual", questionário de múltipla escolha para avaliar o grau de habilidade do ambiente virtual.

b) Compreensão escrita: "Infografía: DNI electrónico", texto apresentado sob a forma de infografias que oferece explicações sobre o novo tipo de documento espanhol (DNI) e introduz vocabulário e estruturas relacionadas com a apresentação pessoal. c) Compreensão oral: "Video: La entrevista", vídeo de um estrangeiro durante entrevista em uma empresa espanhola. Ensina vocabulário e estruturas relacionadas a situações formais de apresentação pessoal.

d) Exercícios gramaticais: "Carpeta de actividades", com exercícios de preenchimento e múltipla escolha para praticar as es-

dades, para avaliar e conhecer efetivamente o potencial de cada um dos trabalhos propostos, acesse diretamente o curso Español para Turismo (Premio Cristóbal Villalón) no endereço da FCL-Virtual: <http://lablin.fclar.unesp.br/moodle/course/ category.php?id=14>. 
truturas estudadas nessa seção (datas, formas de tratamento, pronomes).

e) Produção escrita: "Actividad 1: Preguntas sobre el DNI electrónico", perguntas de caráter exploratório sobre a compreensão da infografia apresentada; "Actividad 2: Entrevista", perguntas de caráter exploratório sobre a compreensão do vídeo da entrevista.

f) Produção discursivo-textual: "Actividad 3: Formularios", análise dos aspectos discursivo-textuais relacionados aos tipos de dados presentes em formulários turísticos da Espanha e do México; "Tarea de la semana: Mi perfil”, edição do perfil do usuário do ambiente virtual. Para completar a tarefa, o aluno deve utilizar os recursos estudados ao longo da seção.

g) Negociação interpessoal escrita: "Foro general", espaço disponível ao longo do curso para dúvidas e debates entre alunos e entre alunos e professor; "Cafetería", espaço disponível para as discussões em tempo real entre alunos e professor.

h) Produção oral: “¡Hablemos!”, ferramenta de conversação oral entre alunos e entre alunos e professor.

As outras cinco seções apresentam uma estrutura similar, porém com atividades cujo eixo principal muda em função do tópico abordado, centrando-se no desenvolvimento de distintas habilidades e, especialmente, na preparação dos alunos para o trabalho colaborativo e para a realização das tarefas propostas. Como trabalho final, propõe-se um projeto que englobe todas as tarefas desenvolvidas anteriormente, denominado Proyecto Final, que é a elaboração de um Folleto Turístico.

A seguir, apresentamos as demais seções do curso EPT-M1 (figuras 4 a 8):

A partir da seção 3, inicia-se a viagem de descoberta da Espanha como destino turístico. $\mathrm{Na}$ seção anterior, os grupos de trabalho organizaram-se e cada grupo escolheu o tipo de turismo sobre o qual trabalhará. Os grupos seguem juntos até o final do curso, descobrindo de forma colaborativa questões que dizem respeito à via- 


\section{Nuestro destino (semana 2)}

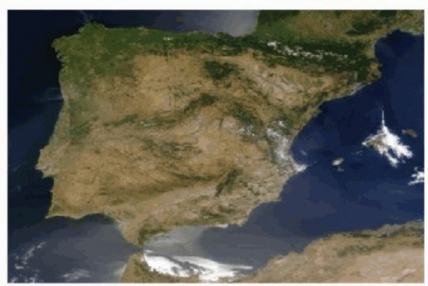

Nuestros objetivos esta semana son conocer España como destino turistico y dividimos en grupos de trabajo para la realización del proyecto final. Ya sabes que puedes acudir en cualquier momento al Foro General.

La tarea de la semana será rellenar el quiz sobre el mapa "España y su gente".

B.tividad 1: ¿Qué sabemos de España?

פVideo: Sector terciario, turismo

Actividad 2. ¿Qué tipo de turismo te gusta?

? Actividad 4: Elección del tipo de turismo

Actividad5: Turismo de sol y playa en España

$\square$ Carpeta de actividades

■T Tarea de la semana 2: España y su gente

Figura 4 - Seção 2 do curso.

gem, aos distintos tipos de hospedagem, ao lazer e à gastronomia típicos das regiões eleitas para o tipo de turista selecionado pelos estudantes para se aprofundar.

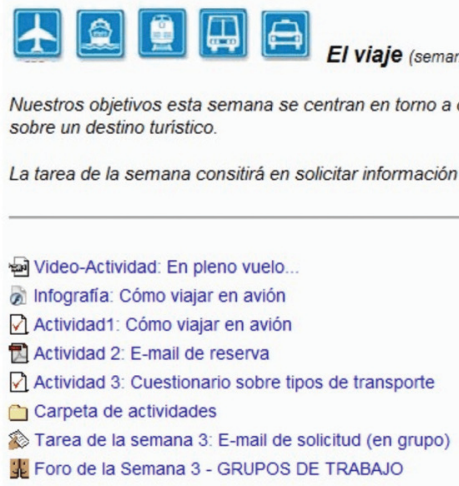

Figura 5 - Seção 3 do curso. 


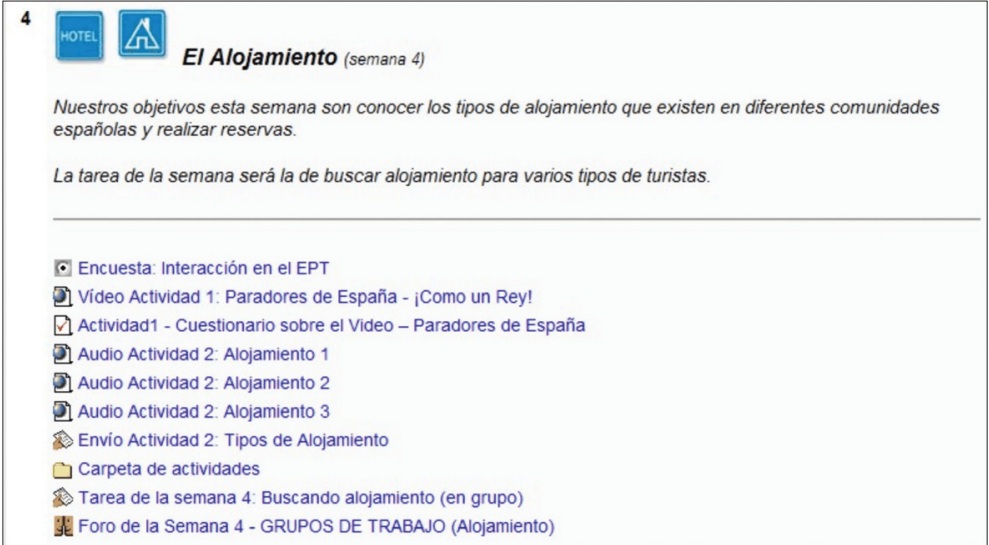

Figura 6 - Seção 4 do curso.

\section{5 [if [1] \\ El Ocio y la Gastronomía (semana 5)}

Los objetivos de esta semana: investigar y dar a conocer las ofertas gastronómicas y de ocio de España. Nuestra tarea será buscar ofertas de ocio y gastronomia para un fin de semana para varios tipos de turistas.

Video1: La tortilla española de patatas

円 Actividad 1 - Cómo se prepara una tortilla española

国 Video2: Un recorrido a pie por el Madrid de los Austrias

Actividad 2 - Ocio y Gastronomía por el Madrid de los Austrias

$\square$ Carpeta de actividades

Tarea de la semana 5: ¿Qué hacemos el fin de semana? (en grupo)

W Foro de la Semana 5 - GRUPOS DE TRABAJO (Ócio y Gastronomía)

Figura 7 - Seção 5 do curso.

\section{Check-out (semana 6)}

Estamos llegando al final de nuestro curso y en esta última semana nuestro objetivo es realizar el Proyecto Final de cada uno de los grupos, darle una forma final, lingüistica y estilisticamente correcta.

Para ello lee atentamente las instrucciones para tu Proyecto Final.

Tarea de la semana 6: PROYECTO FINAL

? ¡HABLEMOS! - Elección de fecha

Wero de la Semana 6 - GRUPOS DE TRABAJO (Proyecto Final)

QUESTIONARIO DE AVALIAÇÃO do CURSO DE EXTENSÃO - ESPAÑOL PARA TURISMO

Figura 8 - Seção 6 do curso. 
Na última seção (Figura 8), realiza-se o Check-out. Os grupos apresentam aos companheiros o resultado de seu trabalho no Proyecto Final, que consiste, como já mencionamos, na elaboração de um folheto de divulgação turística, gênero específico da área do turismo que reúne o trabalho de todas as tarefas realizadas em um único trabalho.

\section{Algumas ponderações depois da experiência em primeira pessoa...}

As questões de ordem tecnológica obviamente não são desprezíveis quando se ensina-aprende uma língua em contexto virtual. Em cada época e em situações concretas, condições técnicas (como a capacidade de banda da internet) e questões de cunho pedagógico (como a fluência ou o grau de letramento tecnológico de cada um dos envolvidos no curso) têm de ser levadas em conta. Ambos os aspectos, como podemos ver na Figura 9, definem se podemos utilizar o meio somente para delivery ou se, ao contrário, podemos utilizá-lo como um verdadeiro ambiente vivo, onde se possa trabalhar e estar junto virtualmente.

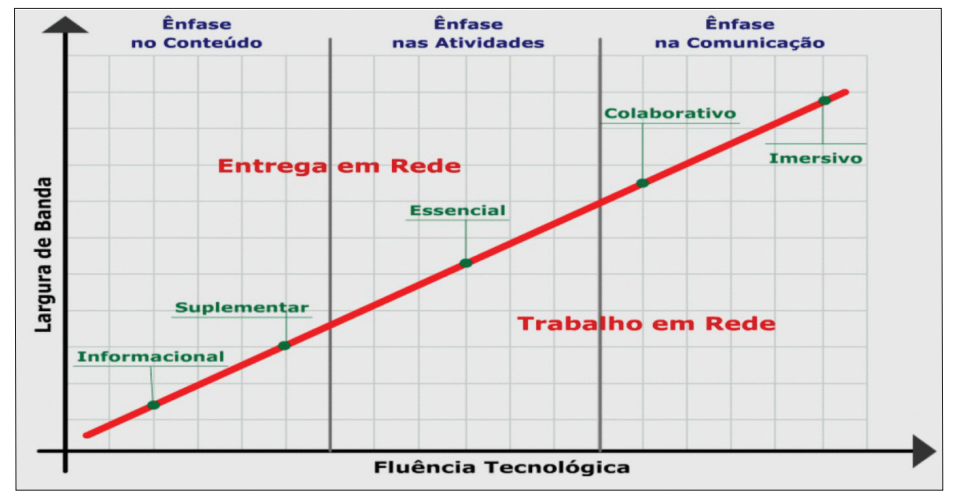

Figura 9 - Fases e possibilidades de educação mediada por tecnologia digital.

Fonte: Filantro, 2003, apresentado por Kenski no II Encontro CAPES-DGU: Linguagem, Educação e Virtualidade. 
Entretanto, é necessário destacar que o aspecto mais determinante é nossa consciência e discernimento quanto às opções teóricas que fundamentam o modo como concebemos língua(gem) e aprendizagem. A opção por uma ou outra ferramenta deve ser realizada em função da forma como esses instrumentos podem potencializar nossos objetivos, ou seja, levar-nos mais perto de onde queremos chegar com o ensino da língua.

O que designamos coloquialmente como meio tecnológico, seja a própria internet ou uma plataforma virtual hospedada em um servidor, é feito de uma matéria extremamente adaptável, diríamos plástica, e, por isso mesmo, acolhe quase qualquer perspectiva, seja ela inovadora ou retrógrada. As possibilidades, como vimos, a partir da apresentação do EPT, são várias e muito interessantes para o trabalho on-line colaborativo. Contudo, é importante destacar que não é o meio que nos garante novas perspectivas no ensino de línguas. Ele contribui, e muito, mas o importante é nossa formação de professor de língua e a experiência em primeira pessoa... (in)formar-se, fazer, refletir, trocar e continuar o círculo virtuoso.

\section{Algumas reflexões}

Conceber um curso fundamentado em uma metodologia colaborativa é bem mais do que desenhar uma determinada mise en écran ou escolher as ferramentas certas. Faz-se necessário colocar em prática, promover e também fazer com que se questionem certos tipos de funcionamento e de concepções tanto de língua como de ensino e de aprendizagem que estão bem assentadas em nossa prática docente e discente.

A partir da perspectiva de professor, depois da experiência com o EPT, acreditamos poder afirmar que o design pode oferecer aos alunos oportunidades para o desenvolvimento de habilidades em colaboração com outros e favorecer práticas efetivas de língua que fazem pensar e posicionar-se no encontro do eu com o outro. Um exemplo: a temática "turismo" no EPT mostrou-se bastante profícua. 
O desenvolvimento do turismo mundial e sua veiculação midiática contribui para fomentar estereótipos que vão se formando no transcurso do tempo. As imagens tradicionalmente associadas às representações coletivas são, em um ambiente colaborativo, muitas vezes postas em xeque. A ideia de Espanha, que tradicionalmente se projeta para o mundo como uma España mediterránea, caliente y latina, contrasta com outras questionáveis, como a dos touros ou a da que trata mal os turistas brasileiros. O fato de o EPT oferecer outras visões sobre os tipos de turismo espanhol pode contribuir com a formação de uma melhor capacidade de identificar e avaliar os tópicos tradicionalmente associados à cultura espanhola, substituindo-os por uma visão crítica, complexa e intercultural sobre a cultura estrangeira. E, no confronto, questiona-se também a cultura nacional.

Por fim, a implementação do EPT como curso de extensão universitária em 2007, na UNESP - Araraquara, gerou grande quantidade de dados, cujas análises já possibilitaram resultados como os trabalhos de Gregolin (2008), Rangel (2008) e Soto, Gregolin \& Mayrink (2009). A partir dessas análises e de outras que estão em desenvolvimento atualmente, é possível afirmar que o design testado no EPT favoreceu um grande espectro de usos da língua espanhola e uma visão muito menos homogênea da realidade cultural hispânica.

No entanto, nem tudo funcionou homogênea e positivamente. $\mathrm{O}$ mesmo desenho do ambiente virtual em conjunto com um trabalho realizado de forma colaborativa parece apresentar, paradoxalmente, tanto aspectos positivos como negativos: para alguns dos alunos oferece oportunidades de encontro e de prazer, para outros, transforma-se em um território em que o indivíduo parece perdido e sem conexão com os demais. Mais estudos, reflexões e experiências são necessários para que possamos determinar que variáveis influenciaram no êxito de alguns e no fracasso de outros. 


\section{Bibliografia}

CELADA, M. T. O espanhol para o brasileiro: uma língua singularmente estrangeira. Campinas, 2002. Tese (doutorado em Estudos da Linguagem) - Universidade Estadual de Campinas.

ESTAIRE, S. Tareas para el desarrollo de un aprendizaje autónomo y participativo. In: ZANÓN, J. La enseñanza del español mediante tareas. Madri: Edinumen, p.55-71, 1999.

FILANTRO, A. Design instrucional contextualizado: educação e tecnologia. São Paulo: Senac-SP, 2003.

GARCÍA CARRASCO, J.; GARCÍA PEÑALVO, F. J. Los espacios educativos en el ámbito de internet: un refuerzo a la formación tradicional. Universidad de Salamanca, s/d. Mimeo.

GARCÍA SANTA-CECILIA, A. Las tareas en el plan curricular del Instituto Cervantes. In: ZANÓN, J. La enseñanza del espanol mediante tareas. Madri: Edinumen, p.123-46, 1999.

GREGOLIN, I. V. Estratégias de cortesia em língua espanhola: estudo de caso em fórum on-line com participantes brasileiros. Araraquara, 2008. Tese (doutorado em Linguística e Língua Portuguesa) - Universidade Estadual Paulista.

JOHNSON, D. W.; JOHNSON, R. T.; HOLUBEC, E. J. El aprendizaje cooperativo en el aula. Buenos Aires: Paidós, 1999.

KENSKI, V. M. Comunicação oral e em powerpoint no II Encontro CAPES-DGU: Linguagem, Educação e Virtualidade. Faculdade de Ciências e Letras da UNESP - Araraquara, 2008.

PÉREZ TORRES, I. Diseño de webquests para la enseñanza/aprendizaje del inglés como lengua extranjera: aplicaciones en la adquisición de vocabulario y la destreza lectora. Granada: Editorial Universidad de Granada, 2006.

PIAGET, J. Biologia e conhecimento. Petrópolis: Vozes, 1996.

RANGEL, M. M. S. Fluxo interativo em curso de espanhol a distância on-line: análise da distância transacional. Niterói, 2008. Dissertação (mestrado em Letras) - Universidade Federal Fluminense.

SOTO, U.; GREGOLIN, I. V.; MAYRINK, M. F. et al. Novas 
tecnologias na sala de aula: (re)construindo conceitos e práticas. São Carlos: Claraluz, 2009.

VIGOTSKY, L. S. A construção do pensamento e da linguagem. São Paulo: Martins Fontes, 2001. 



\title{
O AMBIENTE VIRTUAL DE APRENDIZAGEM (MOODLE) COMO FERRAMENTA AUXILIAR NO PROCESSO ENSINO-APRENDIZAGEM: UMA QUESTÃO DE COMUNICAÇÃO
}

\author{
Márcia Helena Sauáia Guimarães Rostas \\ Instituto Federal de Educação do Maranhão \\ Campus Monte Castelo \\ Bolsista Capes-Dinter-UNESP/UFMA/Cefet-MA \\ Guilherme Ribeiro Rostas \\ Instituto Federal de Educação do Maranhão \\ Campus Centro Histórico
}

\section{Introdução}

Poderíamos começar este breve ensaio afirmando que "estamos inseridos em uma sociedade complexa, contraditória e inundada de informação" (Alarcão, 2005) e que tal fato exige novas competências de acesso, avaliação e gestão da informação disponibilizada de forma maciça a todas as pessoas. Não saber lidar com esse bombardeio de dados pode ocasionar sérios problemas no que tange a aspectos que envolvam os mais simples processos de comunicação.

Acreditamos que a relação entre professor e aluno deva ser próxima e que a competência comunicativa consiga ser desenvolvida, uma vez que ambos dominam não só códigos de linguagem semelhantes, mas compreendem, fazem uso, discutem dados originados da vivência mútua de um universo que se transforma, constroem universos e os desconstroem também.

Analisar essa complexidade do contexto social é um importante indicador para a compreensão dos diferentes dilemas enfrentados pela educação, uma vez que o que ocorre na sociedade tem reflexo direto na escola e, em consequência, o que ocorre na escola reflete na sociedade. Sendo assim, acreditamos que aprender, atualmente, 
pressupõe o desenvolvimento da capacidade de discernir, questionar e refletir sobre as informações recebidas para se chegar ao conhecimento. Concebida como competência de contextualização, as informações criam relações entre si, abrindo oportunidades para uma compreensão mais complexa dos fenômenos, aproximando-se da totalidade destes.

Podemos, mais uma vez, afirmar que esse cenário descrito não é de uma escola estanque, parada no tempo e à espera de que as coisas ocorram, mas uma escola que comporta diferentes ambientes e ferramentas de aprendizagem. Percebe-se que um ambiente pode ser concebido em todos os espaços que compõem o território escolar (dentro e fora da instituição), da mesma forma que as ferramentas pedagógicas, que não se restringem ao uso de máquinas e computadores, também os comporta.

O dicionário Aurélio define ambiente da seguinte maneira: "adj. envolvente; local que rodeia os corpos por todos os lados; s. m., a esfera social em que se vive; o ar que se respira; tudo aquilo que envolve os seres vivos e as coisas"; e aprendizagem como: "Ação de aprender e aprender é mudar de postura, de visão, rever, reinventar [...]". Ao somar as duas definições, podemos inferir que um ambiente de aprendizagem seria o espaço que cerca, envolve os seres vivos (professores, alunos e comunidade escolar) e as esferas sociais com o intuito de mudar, ver, rever, reinventar.

Desse modo, ao tratar da reflexão sobre ambiente de aprendizagem e, mais profundamente, sobre ambientes virtuais de aprendizagem (AVA), torna-se necessário analisar as potencialidades dos recursos tecnológicos disponíveis e discutir a formação dos professores para que reflitam, interpretem e utilizem criticamente a tecnologia no contexto educacional.

\section{Nossas escolas hoje têm propiciado verdadeiros ambientes de aprendizagem aos estudantes?}

Como fugir do uso das tecnologias na escola? Acaso lápis, caneta, livros, revistas, televisão, impressos, giz, quadro-negro, quadro 
verde ou branco, apagador, DVD, filmes, músicas não são tecnologia? Muitas vezes não acreditamos ser possível trabalhar em um ambiente escolar usando tecnologia, mas estamos fazendo isso a todo instante.

Este texto irá descrever a experiência de se trabalhar com um ambiente virtual de aprendizagem (AVA) que propiciou grande interação com os alunos de uma sala de graduação composta por 26 alunos.

Sampaio e Leite (1999) atentam para o fato de que as diferentes tecnologias desenvolvidas hoje, além de disponibilizarem grande volume de informação, modificam as formas de comunicação por meios cada vez mais complexos. Diferentes autores destacam a necessidade de uma problematização desses processos no âmbito escolar e educacional em geral (Perrenoud, 1999; Sampaio \& Leite, 1999).

A educação a distância, que há muitos anos vem sendo desenvolvida mediante o ensino por correspondência, transmissões via rádio e TV, agora ganha novas dimensões ao utilizar as atuais tecnologias digitais e a internet. Apropriando-se desses recursos, a educação a distância amplia suas possibilidades no tocante à superação de um paradigma de transmissão de conhecimento em massa. Será possível, então, pelo menos imaginar que, na educação presencial, o uso dessa ferramenta, complementando as lacunas e propiciando o acesso a outros recursos de fixação da aprendizagem, possa ser um instrumento de grande valia?

Ao utilizar recursos tecnológicos comuns na sociedade da informação em benefício do processo de ensino-aprendizagem, é possível romper o silêncio da escola frente a essas tecnologias e possibilitar o seu uso para além da socialização e acesso à informação, mas também para o desenvolvimento da própria aprendizagem.

Almeida (2005, p.1) pontua algumas características da tecnologia digital quando incorporadas no contexto educacional:

A incorporação da tecnologia de informação e comunicação (TIC) [...] tornou essa modalidade educacional mais complexa devido às se- 
guintes características da tecnologia digital: propiciar a interação das pessoas entre si, das pessoas com as informações disponibilizadas e com as tecnologias em uso; ampliar o acesso a informações atualizadas; empregar mecanismos de busca e seleção de informações; permitir o registro de processos e produtos, a recuperação, articulação e reformulação da informação; favorecer a mediação pedagógica em processos síncronos ou assíncronos; criar espaços para a representação do pensamento e a produção de conhecimento. Dentre essas características, merece destaque o registro, devido à possibilidade de recuperação instantânea e contínua revisão e reformulação.

Resende (2005) também faz uma análise das possibilidades do uso das tecnologias digitais no processo educativo e identifica, especialmente, a internet como ferramenta potencial na mediação do processo de ensino e aprendizagem. Valente (2005, p.28) aponta a internet como "um dos mais poderosos meios de troca de informação e de realização de ações cooperativas”. Ao contrário dos meios de comunicação de massa, essa ferramenta possibilita uma interatividade entre professor, aluno e tecnologia.

Segundo Vogt (2007, p.1):

parece haver concordância de que se trata de desenvolvimentos tecnológicos e sociais que levam a uma nova atitude diante da internet. $\mathrm{O}$ acento não está na tecnologia, mas na nova forma de utilização da internet.

Silva (2006) explicita que dentro de um ambiente on-line se valorizam a interação e a troca de informações entre professor e aluno, no lugar da reprodução passiva de conteúdos utilizando a oratória, mas essa postura não é determinada somente pela escolha tecnológica.

Nas palavras de Moran (2006, p.41):

pode-se definir educação com uso da tecnologia on-line como o conjunto de ações de ensino-aprendizagem desenvolvidas por meios telemáticos, como a internet, a videoconferência e a teleconferência. 
$\mathrm{O}$ ambiente virtual de aprendizagem, que representa a sala de aula on-line, é um conjunto de interfaces, ferramentas e estruturas decisivas para a construção da interatividade e da aprendizagem. É importante ressaltar que o AVA favorece a interatividade e a conexão de teias abertas que formam a trama das relações (Silva, 2006). Esse tipo de ambiente baseia-se na concepção de interatividade, que envolve a participação colaborativa, bidirecional e dialógica, pressupõe a compreensão de conhecimento como algo (hiper)textual, aberto a conexões, à integração de várias linguagens (sons, textos, imagens) e âncoras, e na abordagem da educação como "um sistema aberto, com mecanismos de participação e descentralização flexíveis, com regras de controle discutidas pela comunidade e decisões tomadas por grupos interdisciplinares" (Silva, 2006, p.9).

De acordo com Almeida (2003), ambientes virtuais de aprendizagem são sistemas computacionais disponíveis na internet que permitem integrar diferentes mídias, linguagens e recursos, apresentar informações, desenvolver interações, produzir e socializar produções, independente do tempo e do espaço de cada participante.

Acreditamos que muito mais do que o próprio ambiente, com interfaces e possibilidades de uso de diferentes mídias, o diferencial pode estar na postura assumida pelos participantes, considerando experiências, conceitos e significações, concepções sobre o que é ensinar e aprender, posicionamento crítico e reflexivo, enfim, a atitude diante do uso de tal tecnologia que influencia, significativamente, no processo de aprendizagem.

$\mathrm{O}$ uso adequado dos AVAs para uma educação inovadora deve estimular a curiosidade, a colaboração, a resolução de problemas, a busca e a contextualização de informações (Moraes, 2002). O ambiente virtual de aprendizagem utilizado e que será descrito aqui é o Moodle. Além de ser gratuito e open source, ${ }^{1}$ o Moodle permite que

1 Sistema (códigos de programação) aberto que permite ao usuário que o adapte às suas necessidades sem prescindir de autorização do programador que desenvolveu o pro- 
seu ambiente seja modelado para se adequar às necessidades e ao projeto de cada instituição. Possui interfaces para interação síncrona ${ }^{2}$ e assíncrona ${ }^{3}$ entre os participantes do processo de ensino-aprendizagem e está baseado em um paradigma de aprendizagem colaborativa. Apesar de oferecer recursos para uma proposta pedagógica inovadora, isso dependerá da postura da escola, do professor e de suas concepções de ensinar e aprender, como discutiremos a seguir.

\section{Moodle: um ambiente virtual de aprendizagem}

Com a finalidade de familiarizar o leitor com o ambiente Moodle, este espaço ficou reservado para descrevê-lo. Assim podemos afirmar que:

- O Moodle, sendo um AVA, potencializa a aprendizagem colaborativa, apresentando diversos recursos importantes, dentre eles: chat, fórum, mensagem, workshop (oficina de trabalho) e wiki (coleção de documentos em hipertexto).

- O Moodle é um sistema de administração de atividades educacionais destinado à criação de comunidades on-line.

- O Moodle aplica-se tanto à forma como foi feito como a uma sugestiva maneira pela qual um estudante ou um professor pode se integrar estudando ou ensinando um curso on-line. Dispõe de uma proposta bastante diferenciada: "aprender em colaboração” no ambiente on-line. Informações mais detalhadas dessa ferramenta podem ser encontradas no endereço http://moodle.org.

Martin Dougiamas desenvolveu esse projeto e lidera as pesquisas até hoje. Segundo ele:

grama. Além disso, tal situação possibilita que desenvolvedores no mundo todo criem novos módulos (programas aplicativos), que possam ser incorporados ao programa principal. Essas implementações são realizadas de forma colaborativa, proporcionando a constante atualização do programa sem custos (financeiros) aos usuários.

2 Comunicações instantâneas, on-line (ex.: chat).

3 Comunicação realizada em tempos distintos (ex.: e-mail, fórum, etc.) 
não só trata a aprendizagem como uma atividade social, mas focaliza a atenção na aprendizagem que acontece enquanto construímos ativamente artefatos (como textos, por exemplo), para que outros vejam ou utilizem.

Trata-se de um espaço aberto, livre e gratuito, que pode ser carregado, utilizado, modificado e até distribuído. Isso faz com que seus usuários também sejam seus "construtores", pois, enquanto o utilizam, contribuem para sua constante melhoria.

É importante destacar que, da mesma forma, é indicado para outros tipos de atividades que envolvem formação de grupos de estudo, treinamento de professores e até desenvolvimento de projetos. Existem outros setores, não ligados diretamente à educação, que utilizam o Moodle.

\section{A experiência no IFMA: relembrando as aulas através dos registros}

Esta é a parte mais interessante deste ensaio, uma vez que aqui poderemos, juntos, retomar a sala de aula, os alunos e suas impressões, experiências e descobertas ocorridas há mais de um ano. Será que isso é possível? É tão possível, que cada leitor poderá se colocar no lugar daqueles estudantes.

Na Figura 1, é possível visualizar a página de entrada da sala de aula virtual do curso de Engenharia Elétrica da disciplina Monografia I. É importante ressaltar que os alunos tinham aulas presenciais, em horários determinados dentro da estrutura curricular, e que o objetivo do ambiente virtual era complementar e enriquecer o curso. Esse espaço ficava disponível todos os dias, a qualquer hora, incluindo feriados e fins de semana. Nele, havia todas as aulas ministradas, links complementares que proporcionavam aos alunos o aprofundamento de conteúdos trabalhados, bem como uma "cafeteria", local onde se encontravam e discutiam virtualmente assuntos alusivos à aula, a conteúdos complementares, além de se aproximarem, o que nem sempre era possível no ambiente real, 
seja por motivos circunstanciais (tempo, disciplinas com horários não compatíveis) ou por motivos emocionais (vergonha, medo de não ser aceito pelo grupo).

Se observarmos a Figura 1, poderemos ver que o usuário pode, ao acessar o sistema, visualizar quem está on-line naquele momento, acessar o fórum da semana com a discussão que norteia o conteúdo da aula presencial, entrar na sala de chat, ler o fórum de notícias e postar uma informação nova. Diante da velocidade da informação, será que a aula pode acabar na sala de aula ou na escola?

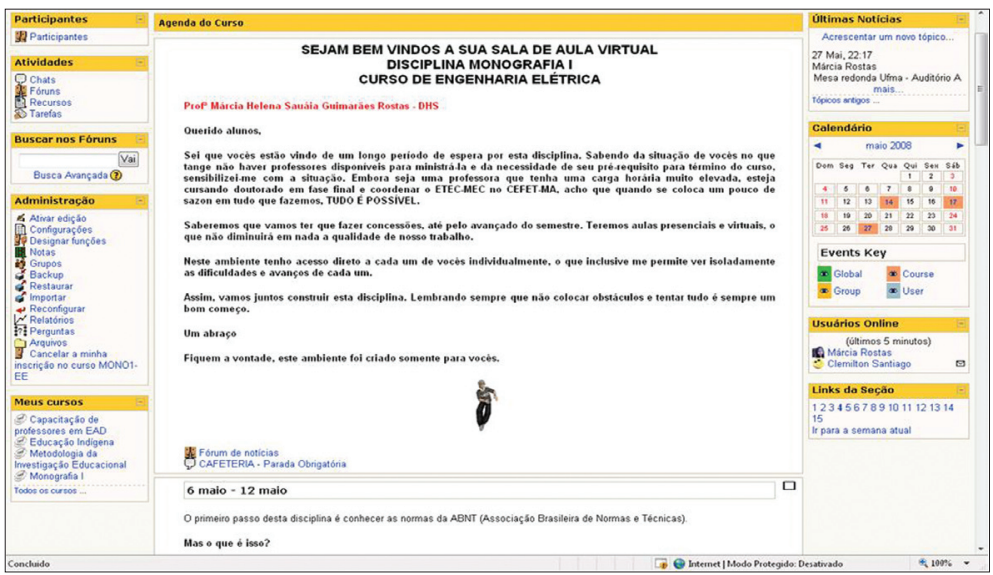

Figura 1 - Página de entrada no Moodle da disciplina Monografia I.

Por outro lado, existem questões que devem ser levantadas em relação ao acompanhamento mais individualizado do aluno, em salas superlotadas. Em uma comunicação assíncrona isso se torna possível, pois o docente terá tempo para "escutar" todos os alunos em um fórum, por exemplo, ou observar suas características individuais (Figura 2). Essa situação torna-se impossível nas aulas presenciais, uma vez que o tempo de uma aula é comumente ocupado com explanações dos professores, que tentam elucidar o conteúdo proposto para estudo. 


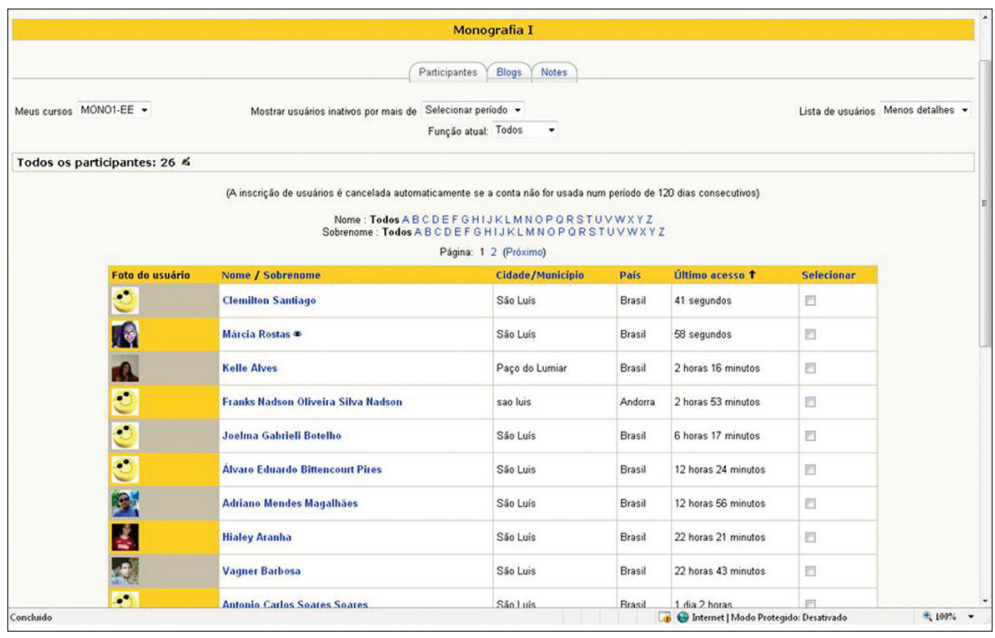

Figura 2 - Relação eletrônica dos alunos matriculados na disciplina Monografia I - ambiente Moodle.

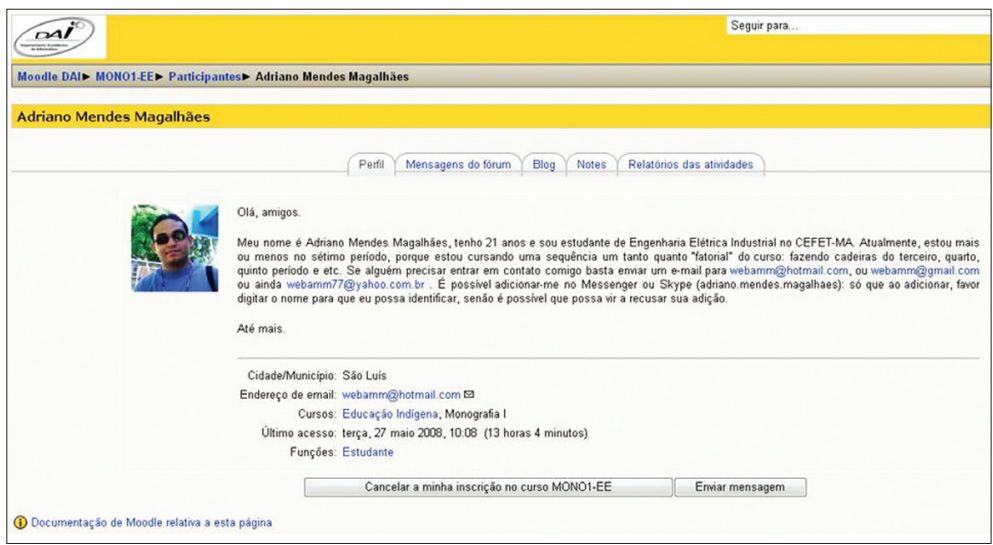

Figura 3 - Perfil de um aluno do curso de Engenharia, matriculado na disciplina Monografia I. 
Numa sala de aula virtual, o professor tem acesso a aspectos individuais de seus alunos, que podem e ficam registrados na memória do servidor que abriga o AVA (Moodle). O professor pode, a qualquer momento, avaliar o interesse ou, até mesmo, o nível de compreensão de seu aluno apenas observando suas intervenções em atividades no fórum, por exemplo (Figura 4).

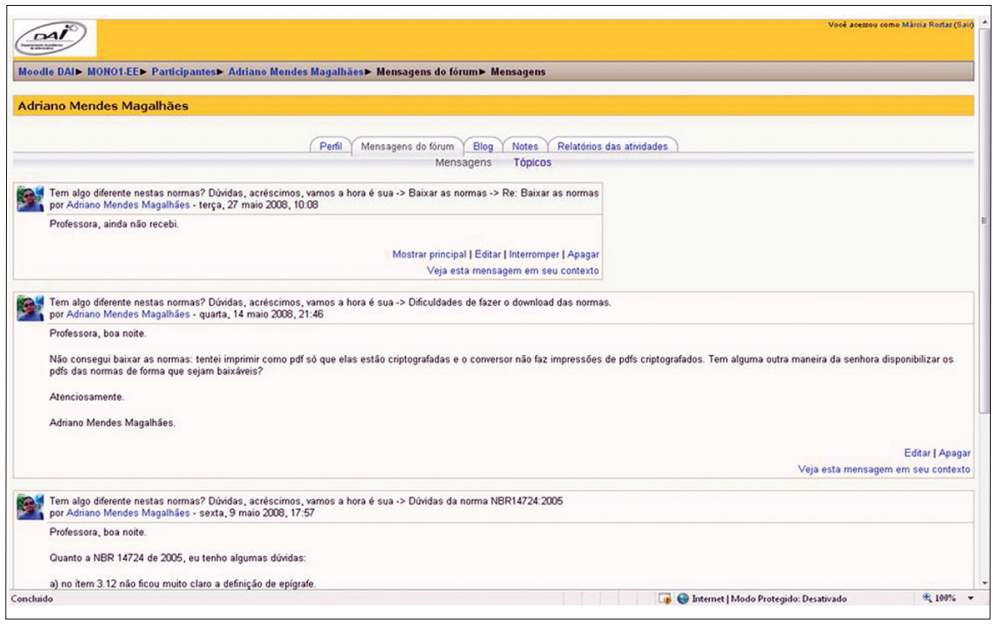

Figura 4 - Mensagens postadas em fórum por aluno da disciplina Monografia I.

O AVA propicia, ainda, que o docente desenvolva uma agenda de tarefas e materiais que possam ser disponibilizados obedecendo uma ordem temporal, por exemplo, por semana (Figura 5). Assim, evita disponibilizar muito material ao mesmo tempo, correndo o risco de que o aluno se perca nos estudos.

Os exemplos aqui apresentados oferecem uma compreensão parcial do ambiente. Referências mais aprofundadas e detalhadas encontram-se disponíveis no site www.moodle.org. Nosso objetivo é introduzir a estrutura de um AVA. 
1 abril -7 abril

Meus queridos alunos, vamos iniciar a terceira semana de trabalhos em nosso curso de MiE, percebam que até agora trabalhamos elementos essenciais como informaçăo e conhecimento. Para que? Bem iniciaremos nossos estudos com um indicatwo de Como Estudar:

A partir dai iremos discutir o que é resumo, resenha, fichamento e esquema.

Veremos normas da ABNT. Associaçăo Brasileira de Normas e Técnicas

Faremos uma visita no Portal da CAPES: http.//periodicos.capes.gov. br/pontugues/index.jsp

E por fím, colocaremos em prática, esses conhecimentos. Para aula de amanhã, o ideal é que tenhamos todos os textos e materiais em mắos, se possivel lidos.

Lembrem-se que as atividades feitas ao final de cada módulo, são objeto de avaliaçăo. Nota é algo construído ao longo da disciplina. Precisamos ter mais disciplinas com nossos compromissos, para isso reserve um tempinho por semana. Bons estudos.

Prop Márcia Rostas

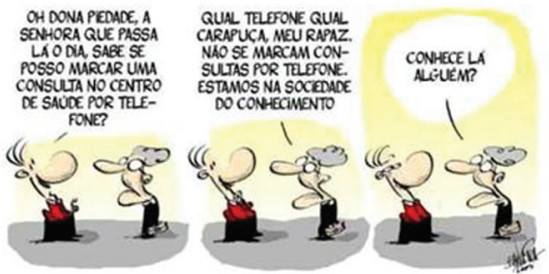

Figura 5 - Bloco de atividades desenvolvidas em uma semana de aulas na disciplina Monografia I.

\section{A lógica educacional em mudança: um "novo" professor on-line}

Quando trabalhamos em uma educação que tem a perspectiva de utilizar tecnologias de ponta, não estamos, necessariamente, modificando a lógica educacional. A mudança da cultura tradicional ${ }^{4}$ não é fácil, as inovações são lentas e, mesmo as mais abertas, podem reproduzir no virtual o modelo centralizador no conteúdo e no professor. Mesmo com a possibilidade de interação e envolvimento entre professores e alunos no ambiente virtual de apren-

4 Entendemos a cultura tradicional como aquela ligada às pedagogias diretivas e ao instrucionismo. 
dizagem, alguns modelos de educação on-line têm utilizado a internet somente como um local para disponibilizar materiais para grande número de alunos, resultado de "práticas pedagógicas instrucionistas, tecnologicamente mais sofisticadas, mas pedagogicamente vazias e empobrecidas" (Moraes, 2002, p.1).

Esse envelhecido paradigma da educação fixou a estratégia da distribuição de conhecimentos como princípio de aprendizagem. As mídias interativas possibilitaram modificar esse modelo, abrindo espaço para a "participação genuína, isto é, participação sensório-corporal e semântica e não apenas mecânica" (Silva, 2005, p.65).

Moraes (2002) discute as novas teorias e metodologias necessárias que venham combater esse modelo de pura repetição, com a utilização de ambientes interativos em suas potencialidades, mediante compreensão do aprendizado como um processo de descoberta e construção individual e coletiva.

Moran (2006), ao retratar o perfil docente, argumenta que, com a educação on-line, multiplicam-se os papéis do professor, exigindo grande capacidade de adaptação e criatividade diante de novas situações, propostas e atividades. Assim, o professor deve aprender a trabalhar com diferentes tipos de tecnologias e garantir uma visão mais participativa do processo educacional: estimular a criação de comunidades, a pesquisa em pequenos grupos, a participação individual e coletiva.

Já Silva (2006) enfatiza que o professor deve ser um construtor de redes, e não de rotas. Alguém que seja capaz de definir um conjunto de territórios a explorar e permita ao aluno a autoria da sua própria experiência. Como aquele que dispõe teias, o professor possibilitaria o envolvimento do estudante, estimulando sua intervenção como coautores da aprendizagem. Sustenta ainda que, mais do que ensinar, o professor deve conduzir o aluno a aprender por meio da criação, gestão e regulação das situações de aprendizagem, desenvolvimento de projetos, resolução de problemas e reflexão individual e coletiva. Ao participar desse processo, o aluno teria a possibilidade da aprendizagem mais efetiva. 


\section{Desafios na formação do professor}

Almeida (2000, p.12) faz uma crítica ao ambiente acadêmico quando afirma que:

a universidade depara-se com desafios provocados pelas transformações, incertezas e complexidade da ciência, pelas demandas da sociedade do conhecimento e pela disseminação das TICs (Tecnologias de Informação e Comunicação).

A partir dessa visão, a universidade deveria enfrentar o desafio da educação nestes tempos em que a tecnologia faz parte do cotidiano das pessoas de forma maciça, abrindo-se para uma postura flexível que propicie o desenvolvimento de propostas inovadoras.

Analisando a possibilidade de uma articulação colaborativa entre ensinos presenciais e a distância, a universidade deveria deslocar o eixo da formação de professores do ensino instrucional para a aprendizagem contextualizada e, ainda que a formação inicial de professores preveja a sua capacitação para uma educação continuada, deve prepará-los para a inovação tecnológica e suas consequências pedagógicas.

$\mathrm{O}$ atual contexto social não permite mais que a formação inicial de professores se esquive do desenvolvimento tecnológico e da própria educação que envolva novas possibilidades de acesso e alcance e que se apresente outro espaço de trabalho que envolva não só professores e pedagogos, mas também designers, analistas, entre outros profissionais.

A discussão sobre a formação do professor é muito antiga, porém, outra vertente de pensamento é agregada a esse objetivo: a alfabetização tecnológica. É possível perceber que a inserção das tecnologias nos processos educativos ainda é uma questão que tem muito a ser explorada e representa a base para entender e atuar como docente na educação presencial, semipresencial e a distância.

É necessário que o professor possua o domínio da linguagem utilizada pelas tecnologias que estão à sua volta e alfabetize-se tecnologicamente. 
A alfabetização tecnológica não pode ser compreendida apenas como o uso mecânico dos recursos tecnológicos, mas deve abranger também o domínio crítico da linguagem tecnológica. (Sampaio e Leite, 1999, p.16)

Isso implica conhecer bem os recursos disponíveis e saber quando eles poderão servir de auxílio para chegar aos objetivos propostos. Essa é, hoje, uma questão estratégica, básica e de sobrevivência profissional.

Perrenoud (1999) sintetiza que, atualmente, é preciso reforçar a preparação de professores para uma prática reflexiva, para a inovação e a cooperação. É preciso formar profissionais reflexivos, dinâmicos, que saibam trabalhar em equipe, buscar e selecionar informações, tomar decisões e desenvolver a autonomia em relação ao próprio processo de aprendizagem.

Pensar a formação docente como uma lista de procedimentos, conteúdos, atividades ou efeitos tecnológicos é adotar uma visão tecnicista dessa formação que se apoia na lógica racionalista de terminalidade, fragmentação, reducionismo e homogeneidade. Retomamos Perrenoud (1999) afirmando que, para a formação de professores, é necessário priorizar orientações baseadas em práticas reflexivas e participação crítica.

Quando as pessoas não são capacitadas para interpretar criticamente as informações e as diferentes linguagens que a tecnologia dispõe, a relação homem-tecnologia acaba tornando-se mais um fator de desigualdade social. Torna-se necessário preparar o professor para o uso pedagógico dessas tecnologias na formação de cidadãos para o contexto da sociedade atual.

\section{Considerações finais}

Considerando a educação virtual algo cada vez mais próximo das gerações vindouras, percebemos que o professor não pode estar alheio a mudanças tecnológicas. Ser reflexivo remete ao pensamento introspectivo das práticas exercidas durante a docência. Um 
educador reflexivo percebe, no ensino contextualizado, a possibilidade de alcançar seu aluno. Os registros em um ambiente de aprendizagem, no nosso caso em AVA, servem para oferecer referenciais de reflexão para o professor. Mesmo não o utilizando em uma educação a distância, é possível perceber as possibilidades, às vezes também os limites, do educador que faz uso de tecnologias para tornar a aprendizagem de seus alunos mais significativa.

Percebemos que tal intenção só pode ser contemplada a partir de práticas não diretivas de ensino ou pedagogias que focam o processo ensino-aprendizagem centrados nos alunos, reconhecendo neles os verdadeiros sujeitos do processo. Assim, o professor assume uma postura de mediação (Vigotsky, 2008) entre o que o aluno pode potencialmente aprender e o que realmente aprende.

Tais procedimentos demandam mudanças de paradigmas, às vezes profundamente imbricados com a personalidade tradicional dos professores. Dessa forma, a reflexividade não pode ser exercitada de forma meramente pragmática, mas se constitui em um movimento interno extremamente dialético, no qual, a todo momento, a contradição apresenta-se.

Mesmo que essa realidade surja de forma complexa para o professor, torna-se um desafio cujos frutos colhidos por aqueles que ousam são doces e gratificantes, pois propiciam a realização da diferença na educação, ou seja, deixam de ser meros reprodutores de ideologias para se tornarem agentes de transformação, colaborando para a construção de sujeitos realmente críticos.

Assim, intuímos lançar esse desafio. O que para muitos pode ser algo tão distante, com a massificação dos meios de comunicação e das TICs, torna-se cada vez mais possível.

\section{Bibliografia}

ALARCÃO, I. Professores reflexivos em uma escola reflexiva. 4.ed. São Paulo: Cortez, 2005.

ALMEIDA, M. E. B. de. Formando professores para atuar em ambientes de aprendizagem interativos e colaborativos. 2000. Dis- 
ponível em <http://www.nave.pucsp.br/doc/formando.doc $>$. Acesso em 24/8/2007.

. Educação a distância na internet: abordagens e contribuições dos ambientes digitais de aprendizagem. Educação e Pesquisa (São Paulo), v.29, n.2, jul.-dez., 2003.

. Desafios e possibilidades da atuação docente on-line. PUCViva (São Paulo), n.24, jul-set., 2005.

MORAES, M. C. (Org.). Educação a distância: fundamentos e práticas. São Paulo: Unicamp/NIED, 2002.

MORAN, J. M. Contribuições para uma pedagogia da educação on-line. In: SILVA, M. (Org.). Educação on-line: teorias, práticas, legislação e formação corporativa. 2.ed. São Paulo: Loyola, p.41-52, 2006.

PERRENOUD, P. Formar professores em contextos sociais em mudança: prática reflexiva e participação crítica. Revista Brasileira de Educação (São Paulo), n.12, p.5-21, set., 1999.

RESENDE, R. S. Fundamentos teórico-pedagógicos para EAD. In: Congresso Internacional de Educação a Distância, 12. Florianópolis: Anais eletrônicos do Congresso Internacional de Educação a Distância. Disponível em <http://www.abed.org.br/ congresso2005/por/pdf/055tcb5.pdf > . Acesso em 24/8/2007.

SAMPAIO, M. N.; LEITE, L. S. Alfabetização tecnológica do professor. Petrópolis: Vozes, 1999.

SILVA, A. Processos de ensino-aprendizagem na era digital. $O$ Professor, Portugal, n.93. Alfragide: Caminho, mai.-ago., 2006. Disponível em <http://www.bocc.ubi.pt/pag/silva-adelina-processos-ensino-aprendizagem.pdf $>$. Acesso em 26/11/2007.

SILVA, M. Criar e professorar um curso on-line: relato de experiência. In: SILVA, M. (Org.). Educação on-line: teorias, práticas, legislação e formação corporativa. 2.ed. São Paulo: Loyola, 2006.

. Internet na escola e inclusão. In: ALMEIDA, M. E. B. de; MORAN, J. M. (Org.). Integração das tecnologias na educação: salto para o futuro. Brasília: Ministério da Educação, p.62-9, 2005. 
Sala de aula interativa. Rio de Janeiro: Quartet, 2000.

TAVARES, K. C. O professor virtual: reflexões sobre seu papel e sua formação. Projeto LingNet. 2001. Rio de Janeiro. Disponível em <www.lingnet.pro.br/papers/eadprof.htm>. Acesso em 23/8/2007.

VALENTE, J. A. Pesquisa, comunicação e aprendizagem com o computador: o papel do computador no processo ensino-aprendizagem. In: ALMEIDA, M. E. B. de; MORAN, J. M. (Org.). Integração das tecnologias na educação: salto para o futuro. Brasília: Ministério da Educação, p.22-31, 2005.

VIANNA, H. M. Pesquisa em educação: a observação. Brasília: Plano, 2003.

WENGER, E. Informal learning. Conferência apresentada na E-learning Lisboa 2007, EU Delivering in the Lisbon Agenda, Centro de Congressos de Lisboa, 15-16 out. 2007.

VIGOTSKY, L. S. Pensamento e linguagem. 4.ed. São Paulo: Martins Fontes, 2008. 



\title{
DeUtSCHKURS KULTURENANNÄHERUNG: UMA PROPOSTA PARA A FORMAÇÃO CONTINUADA ON-LINE DE PROFESSORES
}

\author{
Cibele Cecilio de Faria Rozenfeld \\ PG UNESP - Araraquara/Bolsista CNPq \\ Ana Maria de Senzi Moraes Pinto \\ UNESP - Araraquara
}

\section{Introdução}

As possibilidades oferecidas pelas novas tecnologias de informação e comunicação (NTICs), importante marca da sociedade de informação contemporânea, e as mudanças acarretadas por seu uso, são hoje abordadas em inúmeras investigações de distintos campos de estudo. O uso da internet amplia as possibilidades de interação, cria novos espaços sociodiscursivos, novos gêneros discursivos (Araújo, 2007, p.15), rompe barreiras de tempo e espaço, permite fácil acesso a novos conhecimentos e informações, acarretando transformações sociais vertiginosas. Por essa razão, autores caracterizam o fenômeno como o segundo dilúvio (Roy Scott apud Lévy, 1999, p.13) ou o tsunami digital (Araújo, 2007, p.17), visto que desafia instituições, transforma estruturas arcaicas, impõe verdadeiros desafios à vida cotidiana, profissional e pessoal.

Diante de tal fato, fica evidente a grande importância de programas de formação continuada de professores, destacada de forma recorrente em trabalhos da área educacional e do ensino de línguas.

Todavia, apesar de os fatos apontarem para uma lógica aparentemente simples, a realidade de muitos professores brasileiros apresenta-se bastante desfavorável à sua formação continuada: são 
profissionais sobrecarregados de atividades, com pouco tempo disponível, empregos em mais de uma instituição de ensino para poderem garantir uma condição financeira razoável, grande volume de compromissos profissionais que vão além das paredes institucionais, pilhas de exercícios e provas para corrigir, aulas para preparar e pouquíssimo tempo para frequentar cursos e investir (tempo e dinheiro) em sua formação. É muito comum o professor sentir a necessidade de um aprimoramento profissional, seja no campo do conhecimento específico seja no metodológico, não conseguindo, no entanto, vencer os obstáculos da falta de tempo e de mobilidade.

Trabalhando há anos com o ensino de línguas estrangeiras, mais especificamente como professoras de alemão e na coordenação de cursos em institutos de idiomas ${ }^{1}$ ou em formação inicial, ${ }^{2}$ verificamos que essa realidade é também recorrente entre os profissionais da área de ensino de alemão. Percebemos que muitos desses professores em atividade gostariam de buscar maior aprimoramento linguístico, conhecimento acerca da cultura-alvo e de trocar experiências com outros profissionais, mas a limitação de tempo, bem como as grandes distâncias, muitas vezes não permitem que concretizem um projeto.

Os fatos expostos foram os elementos propulsores para a elaboração de um programa de formação continuada on-line para professores de alemão, a fim de que esses profissionais pudessem não apenas buscar novos caminhos de desenvolvimento de suas competências para aprimoramento profissional em uma sociedade em transformação, mas também para maior familiarização com o uso das NTICs e a promoção de interação com outros profissionais da área.

Neste trabalho, descreveremos o curso proposto. Para tanto, apresentaremos inicialmente alguns dos preceitos teóricos que de-

1 Referência à autora Cibele Cecílio de Faria Rozenfeld.

2 Referência à autora Ana Maria de Senzi Moraes Pinto. 
ram suporte à concepção do curso, passando em seguida para uma descrição do curso virtual.

\section{Bases teóricas para a elaboração do programa de formação continuada}

A concepção do curso foi ancorada, teoricamente, em dois eixos teóricos principais: a importância do uso de novas tecnologias em processos educacionais contemporâneos e a relevância da formação continuada de professores e do desenvolvimento de suas competências.

Na perspectiva do primeiro eixo temático, encontramos, atualmente, inúmeros pesquisadores da área da educação (Litto \& Formiga, 2008; Maia, 2003; Moran, 2000; Almeida, 2003; Valente, 2008) e do ensino de línguas materna e estrangeira (Leffa, 2005, 2006; Marquesi, Elias \& Cabral, 2008; Araújo, 2007; Paiva, 2005, 2006, 2008; Collins \& Ferreira, 2004) que focalizam a utilização de novas tecnologias e novos meios de comunicação em processos educacionais contemporâneos.

O crescimento do número de trabalhos com foco na educação por meio de novas tecnologias justifica-se na medida em que a disseminação do computador em rede possibilita a realização de atividades muito distintas das desenvolvidas presencialmente, por exemplo, as realizadas em diferentes espaços por alunos e professores conectados simultaneamente (atividades síncronas) ou em tempos diferentes (atividades assíncronas), e as atividades multimidiáticas. $\mathrm{O}$ acesso a novos conhecimentos em um ou vários clics favorece a aprendizagem colaborativa, a autonomia, o encurtamento de distâncias, a autogestão do tempo por parte dos alunos e do professor e a ampliação dos espaços de aprendizagem.

Tais características transformam as tradicionais concepções de ensino e de aprendizagem, do papel do professor e dos alunos, e a relação conhecimento/tempo e modificam as relações estabelecidas no processo de ensino e aprendizagem.

Segundo Litto e Formiga (2008), "por meio das NTICs, os mo- 
delos de aprendizagem finalmente ultrapassaram o universo limitado dos educadores e invadem todas as células da vida social e econômica". Em perspectiva contemporânea, o processo de aprender ocorre não somente em espaços institucionais, como também, fortemente, além deles. Por sua vez, o processo de ensinar é muito mais que a mera transmissão de informações; é refletir, ouvir, entender, respeitar, aceitar, facilitar, provocar, motivar, promover reflexão, mediar, interagir.

Tais mudanças são observadas também no campo do ensino de alemão e, em consequência, é necessário que os professores dessa língua revejam suas propostas metodológicas, tendo em vista que os alunos possuem ampla possibilidade de confronto com conteúdos disponíveis na rede.

A rede disponibiliza uma avalanche de material a qualquer pessoa que tenha acesso a ela. Torna-se, pois, tarefa educacional do professor orientar o aluno na seleção, na avaliação e no uso desse material. Para isso, é necessário que ele próprio conheça, teste, experimente, analise e arrisque usar recursos midiáticos para fins pedagógicos, com o intuito de poder orientar seus alunos com indicações valiosas de insumos disponibilizados na web. Isso implica a necessidade de desenvolvimento de habilidades específicas, como a tecnológica, tanto do professor como do aluno.

Esse quadro nos remeteu aos estudos que apontam para a enorme relevância de programas de formação continuada de professores e para o desenvolvimento de suas competências.

No campo da educação, autores como Zeichner e Liston (1996), Smith (1987), entre outros, enfatizam a necessidade de uma formação de professores longa, contínua, privilegiando-se o processo reflexivo, a fim de gerar mudanças de ações e de práticas.

Voltando nosso olhar para o ensino de línguas, também verificamos a grande preocupação de pesquisadores com o processo de formação continuada de professores de línguas estrangeiras. Destacamos os trabalhos das autoras Celani (2003) e Gil \& Vieira- Abrahão (2008), que reuniram importantes investigadores da área para discussão do tema e apresentação de propostas. 
A formação continuada de professores com foco no desenvolvimento de competências é ressaltada, por exemplo, nos trabalhos de Perrenoud (1999, 2000), pesquisador do campo da educação, e de Almeida Filho (1993, 2005), Basso (2001) e Consolo \& Teixeira da Silva (2007), da área de ensino de línguas. O ponto de convergência dos diferentes trabalhos está na enorme relevância de programas de formação inicial e continuada que contemplem o desenvolvimento de diferentes competências de professores para o aprimoramento da prática docente.

As reflexões supraexpostas de forma breve orientaram e fundamentaram a concepção do curso on-line de formação continuada para professores de alemão Deutschkurs Kulturenannäherung: aproximação de culturas a distância.

Apresentamos no próximo bloco uma descrição do curso, passando por seus objetivos, ferramentas utilizadas, conteúdo abordado e participantes, e iremos expor, em seguida, as considerações finais.

\section{Descrição do curso on-line de alemão Kulturenannäherung: aproximação de culturas a distância}

O referido curso Kulturenannäherung foi proposto como curso de extensão on-line em uma plataforma aberta de ensino a distância (Moodle), no ambiente virtual da Faculdade de Ciências e Letras da UNESP - Araraquara. Ele foi elaborado durante 2008, oferecido no primeiro semestre de 2009 (de 4 de abril a 9 de maio) e teve como público-alvo principal professores de alemão em serviço. Por acreditarmos ser uma proposta que poderia despertar o interesse também de professores de alemão em formação inicial, determinamos que alunos de cursos de letras (alemão) que preenchessem os pré-requisitos poderiam candidatar-se a uma vaga. Como principais requisitos para participação no curso, foram exigido o nível B1 de proficiência linguística (segundo o Quadro Europeu Comum de Referência de Línguas) em alemão e o acesso fácil e rápido à internet. 
A carga horária estimada do curso foi de trinta horas (ressaltamos aqui a palavra estimada, uma vez que a exata carga horária de cursos on-line não é facilmente calculada), distribuídas ao longo de cinco semanas.

Para a divulgação do curso e a circulação de material informativo, contou-se com a importante colaboração e o apoio da UNESP - Araraquara, da Saepe (Serviço de Apoio à Pesquisa e Extensão), da Appa (Associação Paulista de Professores de Alemão), da Abrapa (Associação Brasileira de Professores de Alemão) e da Bildungskooperation Deutsch (Centro de Cooperação Pedagógica do Instituto Goethe de São Paulo).

A elaboração do curso e seleção de material on-line deu-se a partir de preceitos da abordagem comunicativa ${ }^{3}$ e do ensino intercultural de línguas. ${ }^{4}$ Assim, buscou-se selecionar material digital, de conteúdo atual e significativo, que pudesse despertar o interesse e a motivação dos alunos, apresentar temas da cultura alemã e promover a interação entre os alunos e as discussões sobre aspectos pessoais, culturais germânicos e interculturais.

Com base nas reflexões apresentadas, foram estabelecidos os principais objetivos do curso:

- Favorecer o aprimoramento linguístico de forma colaborativa, por meio do uso de novas tecnologias de informação e da interação com os colegas e com os professores responsáveis.

- Apresentar temas e aspectos do universo cultural alemão, levando a uma maior aproximação entre as duas culturas.

- Favorecer a reflexão sobre aspectos culturais da Alemanha e sobre diferenças interculturais.

3 O conceito abordagem e os princípios da abordagem comunicativa são temas discutidos por diferentes autores, dentre os quais destacamos Almeida Filho (1993).

4 Tomamos, neste trabalho, o conceito de ensino intercultural discorrido por Rozenfeld, que é ressaltado como "aquele que se concretiza tanto no campo linguístico, por meio do contato de alunos com novos códigos linguísticos, quanto no campo do encontro com a cultura-alvo como alteridade" (2007, p.74), buscando maior conhecimento acerca da cultura-alvo, sensibilização para diferenças, além da reflexão sobre a própria cultura. 


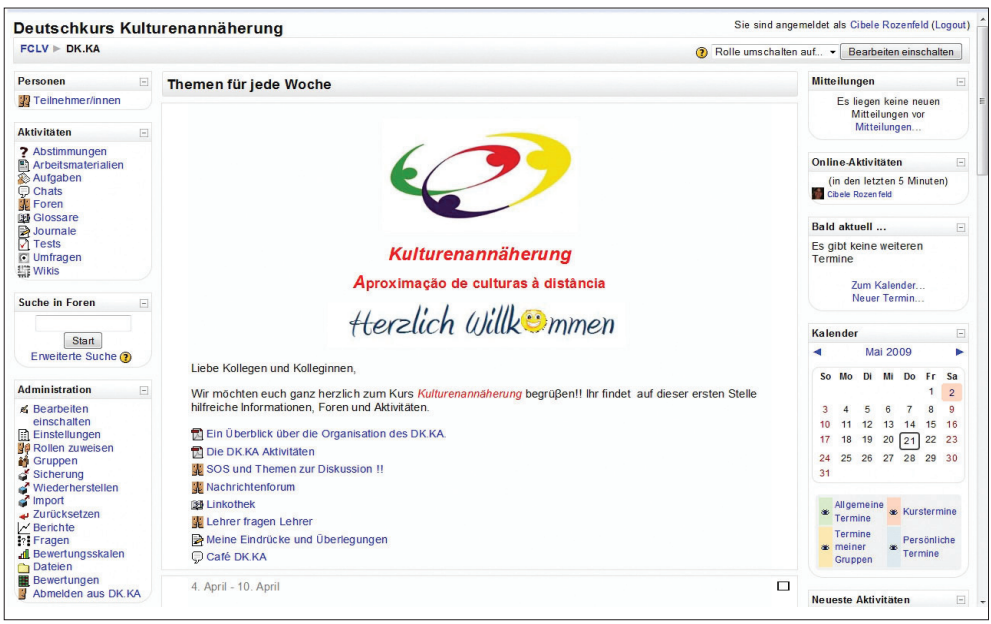

Figura 1 - Recorte do ambiente virtual do curso Kulturenannäherung.

- Promover a vivência na utilização de recursos tecnológicos para fins pedagógicos.

\section{Ambiente DK.KA (Deutschkurs Kulturenannäherung)}

O ambiente virtual Kulturenannäherung foi constituído por três partes: o bloco da esquerda, destinado ao gerenciamento do curso; o bloco central, destinado à distribuição dos módulos com as atividades do curso; o bloco da direita, no qual apareciam algumas informações importantes para os alunos, tais como calendário, notificação de eventos, prazos, visualização dos participantes on-line e notificação de recebimento de mensagem individual. Tal divisão já é fornecida pela plataforma virtual de aprendizagem Moodle. 


\section{Ferramentas utilizadas no ambiente do curso}

\section{- Fóruns}

Os fóruns nos ambientes virtuais de aprendizagem proporcionam a discussão de temas e assuntos diversos. Eles são de grande utilidade para tirar dúvidas, trocar informações e experiências entre os participantes. Cada fórum possui um tema, que pode ser organizado por tópicos, e, para iniciar uma discussão, basta criar um tópico de um assunto no fórum que possa ser respondido pelos alunos e pelo professor.

O fórum é uma ferramenta para atividade assíncrona, ou seja, a troca de mensagens entre os participantes não ocorre em tempo real; as mensagens enviadas ficam registradas e são respondidas em momentos distintos pelos alunos ou pelo professor.

\section{- Glossário}

O glossário permite a criação de uma lista de termos ou temas e, ao ser acessado, possibilita a busca de títulos ou vocábulos por ordem alfabética ou por visão geral.

\section{- Chat}

O chat é uma ferramenta para atividade síncrona, ou seja, de comunicação simultânea, em que os alunos se encontram em tempo real para discutir determinado tema, preestabelecido ou não. É uma ferramenta computacional comumente utilizada para entretenimento.

\section{- Tarefas}

As tarefas permitem aos professores avaliar eletronicamente os materiais enviados por cada um dos alunos. 


\section{- Questionário}

A ferramenta questionário permite a criação de lista de perguntas abertas, curtas ou de múltipla escolha, com possibilidade de controle de tentativas, data de entrega e de correção automática. A ferramenta possibilita que o professor visualize todas as respostas dos alunos e de incidência de respostas.

\section{- Link a um site da web}

Qualquer arquivo da web pode ser disponibilizado no ambiente de aprendizagem pelo uso do recurso link a um arquivo ou site. Dessa forma, é possível disponibilizar filmes, textos eletrônicos, músicas, etc.

\section{- Wiki}

A wiki é uma ferramenta que possibilita o trabalho colaborativo, pois visa à produção em grupo de um texto, e disponibiliza, ao professor, a visualização de todos os acessos, correções e complementações feitas por cada aluno.

\section{- Diário}

Os diários funcionam exatamente como os tradicionais "diários de viagem" ou de registro de atividades do dia. Neles são registradas impressões, análises e avaliações, sem que o conteúdo possa ser visualizado pelos demais alunos. Apenas o professor tem acesso aos diários. A ferramenta oferece também a possibilidade de envio de feedback ao aluno. Dessa forma, é possível que o professor obtenha um relato das dificuldades e expectativas dos estudantes e, com isso, poderá tentar adequar os materiais de módulos futuros a essas manifestações. 


\section{- Escolha}

A ferramenta escolha possibilita qualquer atividade de múltipla escolha e pode ser configurada de forma que as opções dos alunos sejam anônimas ou visualizadas. No DK.KA ela foi utilizada para o levantamento e a determinação de data para realização do chat.

\section{Os módulos do curso DK.KA}

O curso foi dividido em cinco módulos, cada um correspondendo a uma semana.

\section{Módulo introdutório}

O módulo introdutório, disposto no início do bloco central do ambiente, teve como objetivo fazer uma breve saudação aos alunos e disponibilizar alguns recursos considerados relevantes para o trabalho nos demais módulos ao longo do curso. Foram postos à disposição, inicialmente, nessa etapa, dois tutoriais em arquivo PDF que tinham o objetivo de apresentar aos alunos o ambiente e as ferramentas. Em seguida foram apresentadas as primeiras atividades do curso:

- SOS und Themen zur Diskussion!! - Fórum para postagem e discussão de dúvidas sobre as atividades propostas nos módulos do curso ou sobre aspectos de caráter técnico.

- Café DK.KA - Chat para encontros virtuais síncronos. As datas e horários de encontros síncronos (em tempo real) foram determinados no decorrer dos módulos, a partir da utilização da ferramenta "escolha" disponibilizada pela plataforma. Com base nas escolhas dos alunos, eram determinados o dia e o horário do encontro síncrono. Para cada reunião, os professores formadores determinavam um tema para discussão.

- Nachrichtenforum - Fórum para postagem de avisos im- 
portantes do professor. Nesse espaço, as mensagens do professor não podiam ser respondidas, apenas lidas.

- Linkothek - A lincoteca disponibilizava sites interessantes para o ensino e aprendizagem de alemão, organizados por temas na ferramenta glossário. Alguns links foram inseridos pela professora do curso, mas a atividade possibilitava que os alunos também incluíssem sugestões, caso quisessem compartilhar um material com os colegas, favorecendo a aprendizagem colaborativa. O objetivo dessa atividade era levar os professores à rede, indicando páginas interessantes para a aprendizagem e para a atividade docente. Alguns dos sites indicados na lincoteca:

http://www.dw-world.de/

http://www.goethe.de/z/jetzt/deindex.htm

http://www.uiowa.edu/ acadtech/phonetics/

http://firenze.paukerin.com/pauker

http://www.aufgaben.schubert-verlag.de/

http://www.deutschseite.de/inhalt.html\#grammatik

http://www.mein-deutschbuch.de/lernen.php?menu_ id $=1$

http://www.slf.ruhr-uni-bochum.de/bochum-deu.html www.livemocha.com

Os últimos dois sites possibilitam a aprendizagem tandem, que ganhou força a partir da década de 1990, como uma modalidade para aprendizagem colaborativa de línguas estrangeiras e que vem se destacando por implicar colaboração, simultaneidade e comunicação intercultural. A aprendizagem tandem pressupõe parcerias entre falantes nativos de diferentes línguas. Pela lincoteca, os alunos foram informados sobre o Tandem-Server-Bochum, do Projeto E-Tandem Europa, e sobre o site Livemocha, que, além de oferecer a possibilidade de encontro entre parceiros que estejam interessados na aprendizagem das línguas, disponibiliza algumas atividades on-line para serem realizadas pelo aprendiz de uma determinada língua-alvo.

- Lehrer fragen Lehrer [Professor pergunta para professor] - 
Fórum de discussão entre os participantes sobre o processo de ensino e aprendizagem do alemão e da prática de sala de aula.

- Meine Eindrücke und Reflexionen [Minhas impressões e reflexões] - Atividade elaborada na ferramenta diário para relato individual das impressões e das reflexões surgidas ao longo do curso.

\section{Módulo 1. Einstieg in die Arbeit: sich kennen lernen [Início do trabalho: conhecer-se]}

Esse módulo apresentava as diferentes ferramentas do ambiente e fazia os alunos conhecer seus colegas, além de apresentar alguns sites interessantes para o ensino e aprendizagem da língua alemã. Para tanto, foram incluídas algumas tarefas (leitura e compreensão de textos, a partir de indicação de links pertinentes para professores de alemão), fóruns de discussão de dúvidas dos participantes, fórum de discussão sobre os links apresentados na lincoteca.

\section{Módulo 2. Etwas über Deutschland, Deutsch, die Deutschen [Um pouco sobre a Alemanha, alemão e os alemães]}

O tema desse módulo é a Alemanha, sua língua e seu povo. As atividades são iniciadas com um filme do Youtube (www.youtube. com), site de disponibilização livre de vídeos. Ressalta-se aqui o potencial dessa ferramenta como recurso pedagógico: o Youtube é um site gratuito bastante utilizado por jovens internautas para entretenimento. Nele é possível acessar pequenos filmes de temáticas distintas, desde vídeos mais simples e amadores a outros bastante interessantes e adequados para a utilização pedagógica. Ao entrar nesse site, pode-se fazer uma busca por tema, interesse, nome, autor, ou ainda endereço completo de um vídeo específico.

O filme utilizado na abertura desse módulo apresenta cenas do universo cultural alemão. ${ }^{5}$ Após assisti-lo, o aluno deveria respon-

5 O filme utilizado foi Lernen Sie Deutschland kennen. Disponível no Youtube em $<\mathrm{http}: / /$ www.youtube.com/watch?gl=BR\&hl=pt\&v=SMV5H0lnfAw $>$. 
der a questões sobre o filme e, em seguida, visitar sites com informações de Berlim. Após pesquisa nessas páginas, foram abertas discussões em fórum com perguntas sobre a cidade. Depois, os alunos realizaram a revisão do Konjunktiv II a partir de indicação de sites e discutiram o tema wenn ich in Berlin wäre.

Após a realização dessa atividade, os alunos assistiram a um documentário sobre a queda do Muro de Berlim ${ }^{6}$ e escreveram um texto coletivo na wiki com o tema 20 Jahre Mauerfall [20 anos da queda do Muro]. Ainda nesse módulo, os alunos leram uma entrevista de um estudante brasileiro que vive na Alemanha, obtida no site da Deutsche Welle, um jornal alemão, na qual o rapaz relata suas impressões e vivências. ${ }^{7}$ Em seguida, discutiram, em fórum, se concordavam ou não com as opiniões do estudante. $\mathrm{O}$ objetivo da atividade era instigar a discussão sobre aspectos interculturais entre Brasil e Alemanha.

Nesse módulo, bem como nos que se seguiram, foi feito um diário, no qual cada aluno poderia expressar livremente (sempre em alemão) suas impressões e dificuldades durante a realização das atividades do módulo. Esse recurso favoreceu a prática da língua-alvo, a oportunidade de refletir acerca do próprio processo de aprendizagem, assim como o do aluno/professor, e um feedback da execução das atividades, possibilitando o constante diálogo entre alunos/participantes e professores.

\section{Módulo 3. Deutschland: eine Multikulti-Gesellschaft? [Alemanha: uma sociedade multicultural?]}

Nesse módulo pretendeu-se discutir o conceito Multikulti-Gesellschaft. Para tanto, iniciamos com uma tarefa que buscava levantar o conhecimento prévio dos alunos. Os alunos assistiram a

6 Tageschau vom 10. November 1989. Disponível no Youtube em <http://www.youtube.com/watch? $\mathrm{v}=\mathrm{EQpeNuZK-Mc \& feature}=$ related $>$.

7 Fernando aus Brasilien. Deutsche Welle. Disponível em <http://deutsche-welle.de/ $\mathrm{dw} /$ article/0,,4062230,00.html>. 
um documentário que relata a vida de um grupo de turcos radicados na Alemanha, seus anseios e suas dificuldades encontradas naquele país. ${ }^{8}$ Depois de assistir ao filme, os alunos realizaram uma atividade de compreensão e, em seguida, fizeram uma revisão gramatical de algumas conjunções a partir da indicação de sites da web e responderam a algumas questões, elaboradas na ferramenta do tipo tarefa, relacionadas ao filme. A atividade final foi uma discussão, em fórum, sobre o Brasil como Multikulti-Gesellschaft, visando à reflexão sobre as diferenças da cultura alemã em oposição à brasileira.

\section{Módulo 4. Deutsche Kultur: Filme [Cultura alemã: filmes]}

O módulo quatro abordou o tema "Filmes alemães", focalizando em Das Leben der Anderen para a elaboração de algumas atividades. $\mathrm{Na}$ primeira atividade, os alunos deveriam expor seus conhecimentos prévios sobre o filme e, em seguida, assistir a um trailler dele, obtido no Youtube. Posteriormente, deveriam assistir ao filme individualmente e discutir, em fórum, o seu conteúdo. A última atividade desse módulo teve como objetivo a construção de uma videoteca pelos alunos em fórum, indicando um ou mais filmes, e postando para cada um deles uma resenha crítica e o gênero dele. Os colegas poderiam, em resposta, expressar suas opiniões e realizar, assim, uma discussão dos filmes.

\section{Módulo 5 e Módulo 6}

Os módulos 5 e 6 foram elaborados para o trabalho da última semana do curso. A atividade inicial do módulo foi a apresentação de um filme sobre uma aula de alemão bastante controversa, pois ao mesmo tempo que tratava de uma situação fictícia, humorística e irônica de sala de aula, configurava-se como um filme marcado

8 Muslime in Hamburg. Disponível no Youtube em "http://www.youtube.com/ watch? $=$ W_1_T $4 \mathrm{p} 8 \mathrm{p} 3 \mathrm{w}>$. 
por clichês sobre a situação dos turcos na Alemanha. ${ }^{9}$ Por ser paradoxal, foi importante fonte de questões, principalmente em discussões e fórum, sobre a interculturalidade.

Ainda nesse módulo, pediu-se aos alunos que refletissem sobre os aspectos positivos e negativos do curso, de acordo com seus objetivos e expectativas desde o início até o fim das aulas. Finalizando o processo, os estudantes deveriam apresentar um trabalho de conclusão, cujo tema foi Internet im DaF-Unterricht ou Brasilien und Deutschland: Kulturaustausch.

A reflexão sobre o curso feita pelos alunos/professores foi bastante positiva e destacaremos, a seguir, alguns dos aspectos apontados.

\section{Considerações finais}

A utilização de meios digitais para fins educacionais apresenta-se, hoje, em movimento crescente e irreversível e vem despertando o interesse de inúmeros pesquisadores da área.

Diante desse fato e acreditando na relevância do ensino intercultural de línguas, consideramos bastante pertinente a realização de cursos de Kulturenanäherung, por promover a interação entre os alunos/professores de diferentes regiões do Brasil, o desenvolvimento linguístico, a discussão de aspectos interculturais na aprendizagem e ensino da língua alemã e também maior familiarização de professores com algumas ferramentas digitais.

Essa proposta de ensino levou grande vantagem na possibilidade de autogestão de tempo dos alunos/professores, viabilizando aos docentes a conciliação das atividades de formação continuada com as de sua prática profissional. Além disso, possibilitou o acesso de professores em serviço em Salvador, Rio de Janeiro, São Paulo (capital e interior), quebrando assim as barreiras de espaço e tempo.

9 Ladykracher: Deutschunterricht für türkische Mitbürger. Disponível no site My Video em <http://www.myvideo.de/watch/6041569/Ladykracher_Deutschunterricht>. 
$\mathrm{Na}$ avaliação final do curso, em diários reflexivos, mensagens eletrônicas ou fóruns, foram feitas diversas análises positivas sobre a proposta do curso DK.KA pelos alunos/professores de alemão para sua própria formação continuada. Em seus relatos, eles apontaram para o reconhecimento da grande necessidade e desejo de interação com outros professores, de aperfeiçoamento linguístico e profissional. No entanto, alguns deles mencionaram a falta de tempo para a realização de cursos presenciais que pudessem contribuir para atingir esses objetivos.

Dessa forma, um curso da natureza do Kulturenannäherung apresenta-se como alternativa que vem ao encontro das necessidades de professores e alunos, visto que possibilita autogestão do tempo e interação com outros profissionais da área, além do contato com novas ferramentas e novos conteúdos digitais.

É importante também ressaltar os aspectos fracos do curso. Um deles foi o fato de que a produção oral não foi contemplada, aspecto em geral mencionado negativamente pelos alunos/professores nas avaliações. Todavia, acreditamos ser possível pensar em algumas alternativas, como a inclusão de atividades que utilizem ferramentas do Skype ou do Second Life, as quais possibilitariam também a produção oral.

Outro ponto negativo foi de ordem técnica: a instabilidade da conexão em alguns dias e a incompatibilidade do software de alunos com o dos professores. Todavia, consideramos que essas dificuldades foram pequenas diante das vantagens oferecidas pelo curso.

Do ponto de vista dos professores/organizadores, vale ressaltar que o trabalho se mostrou bastante intenso, tanto na preparação, como ao longo do curso. O número de horas de trabalho empregadas ultrapassou consideravelmente as trinta horas previstas. Saliente-se que foi um trabalho extremamente produtivo, prazeroso, com interações diversificadas e intensas, e os resultados ultrapassaram positivamente as expectativas, sendo que alguns alunos expressaram desejo da continuidade do curso.

Apresentamos a seguir alguns dos excertos de avaliações finais, diários ou de fóruns, que evidenciam nossa conclusão: 
Eu acredito que um curso na modalidade a distância pode contribuir muito para a aprendizagem do alemão. Eu pude comprovar isso na prática... A possibilidade de fazer as atividades no horário mais conveniente para mim foi um ponto muito positivo. Eu trabalho muito e nunca poderia participar de um curso presencial por falta de horário... Acho que um curso de língua on-line é muito bom, principalmente para quem já tem uma base. Assim, o aluno pode aprimorar seus conhecimentos sempre. Se eu pudesse, já faria outro curso depois deste. (C. A.)

Sobre a possibilidade de desenvolvimento de competência linguística:

Sim, acredito [que as atividades contribuíram para o aprimoramento linguístico]. Tive de estudar bastante, ler vários textos em alemão, consultar o dicionário algumas vezes, outras vezes buscar gramáticas para verificar possíveis enganos na escrita. Todo esse trabalho enriqueceu meu conhecimento sobre a língua alemã. (J. F.)

Algumas manifestações de apoio à proposta dessa modalidade de curso (originalmente em alemão) podem ser verificadas nos exemplos a seguir:

Excerto de uma discussão no fórum inicial:

[...] Inicialmente gostaria de parabenizar as pessoas que elaboraram este curso. Meus cumprimentos! Devo dizer que, mesmo durante minha graduação, eu sempre quis participar de um curso como este, a fim de melhorar meus conhecimentos de alemão, de poder falar sobre minhas aulas e de poder receber ajuda. No momento está sendo muito difícil para mim trabalhar com adolescentes de 11 a 16 anos, pois ainda não encontrei "o método ideal" para eles. Sempre tento isso... e aquilo... Você entende? Por isso este curso me alegra muito, pois tenho certeza que posso aprender muito com você [professor] e com os colegas...(B. M.)

Excerto de diário: 
[...] Estou muito empolgada com o curso. Em tão pouco tempo, pude reunir tantas informações que certamente poderão ajudar no meu trabalho. Devagar e sempre encontram-se as "saídas"... [vale ressaltar que esta aluna teve uma grande dificuldade inicial no manejo das ferramentas]... A devolução das atividades sobre os textos e dos exercícios foi rápida e as correções claras. Sou muito agradecida por isso e devo cumprimentá-los pelo belo trabalho realizado. ${ }^{10}(\mathrm{H} . \mathrm{M}$.

\section{Excertos de avaliação:}

[...] Poderia-se participar de um curso desta natureza constantemente. O que você acha? Haverá uma continuidade (de curso)? ${ }^{11}$ (N. S.) [...] eu acho tudo ótimo, uma experiência especial, aprendo muito, gosto do curso, as atividades são bem formuladas e apresentadas, as professoras preenchem muito bem as exigências, essa possibilidade de contato é fantástica e agradeço muito pela oportunidade. ${ }^{12}$ (M. D.)

Para finalizar, acreditamos que o curso Deutschkurs Kulturenannäherung, inicialmente pensado como um curso para a aproximação entre as culturas ${ }^{13}$ de Brasil e Alemanha, demonstrou ser adequado também para a aproximação de culturas distintas existentes em nosso país: da cultura do aprender com a do ensinar alemão como língua estrangeira, em grandes metrópoles e no interior,

10 Ich bin begeistert mit dem Kurs. In so kurzer Zeit habe ich viele Informationen gesammelt, die meiner Arbeit sicher helfen können. Auf Schritt und Tritt findet man die "Ausgänge". Die Wiedergabe der bearbeiteten Texten und Übungen waren schnell und klar. Ich bin sehr dankbar dafür und muss euch für die schöne Arbeit gratulieren.

11 Man könte an so einem Kurs dauern teilnehmen. Was meinst du? Gibt es eine Fortsetzung?

12 Ich finde alles super, eine besondere Erfahrung, ich lerne viel, der Kurs macht mir Spaß, die Aufgaben sind gut formuliert und präsentiert, die Leiterinnen erfüllen die Anforderungen so wunderbar, diese Kontaktmöglichkeit ist fantastisch und ich bedanke mich ganz herzlich für die Gelegenheit.

13 Vale ressaltar que entendemos que o construto "cultura" é bastante amplo e de conceitualização complexa e distinta. No entanto, no âmbito deste trabalho, nós o tomamos em seu sentido mais amplo, por não podermos nos estender em discussões sobre as diferentes formas de compreensão do termo. 
no Sul e no Nordeste do país, em escolas públicas, particulares, de idiomas ou de aulas particulares. Realidades distintas, professores buscando alcançar objetivos semelhantes, interações intensas. Foi interessante observar que, ao final do curso, ficou um sentimento de grande proximidade de cada um dos participantes, ainda que o contato tenha se dado estritamente no espaço virtual. Como professoras do curso, experienciamos grande dificuldade para nos desligar do grupo, fechar o ambiente virtual, pois havíamos construído uma forte empatia pelos alunos/professores. Alguns alunos também manifestaram a vontade de manter o contato e, por esta razão, criamos um grupo de discussão, no Yahoo Groups, a fim de tentar manter os vínculos construídos. Porém, o grupo não se manteve por muito tempo em contato.

Não houve ainda tempo hábil para uma análise minuciosa dos dados obtidos durante o curso. No entanto, é possível afirmarmos que a experiência de interação de professores de língua alemã, de vários estados brasileiros, de ensino a distância com a finalidade de aprimoramento docente, é uma proposta inovadora, produtiva e rica que possibilita criação de vínculos a partir das diferentes formas de interação e que vem, também, ao encontro das necessidades de muitos professores em atividade.

\section{Bibliografia}

ALMEIDA FILHO, J. C. P. Dimensões comunicativas no ensino de linguas. Campinas: Pontes, 1993.

. Análise de abordagem como procedimento de auto-conhecimento e mudança para o professor de língua estrangeira. In: (Org.). O professor de língua estrangeira em formação continuada. Campinas: Pontes, p. 11-27, 2005.

ALMEIDA, M. E. B. Educação a distância na internet: abordagens e contribuições dos ambientes digitais de aprendizagem. Educação e Pesquisa, v.29, n.2, p.327-40, 2003. 
ARAÚJO, J. C. (Org.). Internet e ensino: novos gêneros, outros desafios. Rio de Janeiro: Lucerna, 2007.

BASSO, E. A. A construção social das competências necessárias ao professor de língua estrangeira: entre o real e o ideal um curso de Letras em estudo. Campinas, 2001, 181f. Tese (doutorado em Linguística Aplicada) - Instituto de Estudos da Linguagem, Universidade Estadual de Campinas.

CELANI, M. A. A. Professores e formadores em mudança: relato de um processo de reflexão e transformação da prática docente. Campinas: Mercado de Letras, 2003.

COLLINS, H.; FERREIRA, A. (Org.). Relatos de experiência de ensino e aprendizagem de línguas na internet. São Paulo: Mercado de Letras, 2004.

CONSOLO, D. A.; TEIXEIRA DA SILVA, V. L. Introdução. In: (Org.). Olhares sobre competências do professor de língua estrangeira: da formação ao desempenho profissional. São José do Rio Preto: HN, p.13-7, 2007.

GIL, G.; VIEIRA-ABRAHÃO, M. H. (Org.). Educação de professores de línguas: os desafios do formador. Campinas: Pontes, 2008.

LEFFA, V. J. A prendizagem mediada por computador à luz da teoria da atividade. Calidoscópio (São Leopoldo), v.3, n.1, p.21-30, 2005.

- A aprendizagem de línguas mediada por computador. In: . (Org.). Pesquisa em linguística aplicada: temas e métodos. Pelotas: Educat, p.11-36, 2006.

LÉVY, P. Cibercultura. Trad. Carlos Irineu da Costa. São Paulo: Editora 34, 1999.

LITTO, F. M.; FORMIGA, M. (Org.). Educação a distância: o estado da arte. São Paulo: Pearson Education do Brasil, 2008.

MAIA, C. (Org.). Ead.br: experiências inovadoras em educação a distância no Brasil. Reflexões atuais em tempo real. São Paulo: Editora Anhembi Morumbi, 2003. (Série Universidade Virtual).

MARQUESI, S. C.; ELIAS, V. M. S.; CABRAL, A. L. T. Intera- 
ções virtuais: perspectivas para o ensino de língua portuguesa a distância. São Carlos: Claraluz, 2008.

MORAN, J. M. Ensino e aprendizagem inovadores com tecnologias. Informática na Educação: teoria É prática (Porto Alegre), v.3, n.1, p.137-44, 2000.

PERRENOUD, P. Construir as competências desde a escola. Porto Alegre: Artmed, 1999.

10 novas competências para ensinar. Porto Alegre: Artmed, 2000.

PAIVA, V. L. M. O. A www e o ensino de inglês. Revista Brasileira de Linguística Aplicada (Belo Horizonte), v.1, n.1, p.93-116, 2001.

. A pesquisa sobre interação e aprendizagem de línguas mediadas pelo computador. Calidoscópio (São Leopoldo), v.3, n.1, p.5-12, 2005.

- O uso da tecnologia no ensino de língua estrangeira: breve retrospectiva. Disponível em <http://www.veramenezes.com/ techist.pdf>. Acesso em 10/10/2008.

ROZENFELD, C. C. F. Crenças sobre uma língua e cultura-alvo (alemã) em dimensão intercultural de ensino de língua estrangeira. São Carlos, 2007, 203f. Dissertação (mestrado em Ensino e Aprendizagem de Línguas) - Universidade Federal de São Carlos.

SMITH, J. Educating teachers: changing the nature of pedagogical knowledge. Londres: The Palmer Press, 1987.

VALENTE, J. A.; ALMEIDA, M. E. B. Formação de educadores a distância e integração de mídias. São Paulo: Avercamp, 2008.

ZEICHNER, K. M.; LISTON, D. P. Reflective teachers. Nova York: Lawrence Erlbaum Associates, 1996. 



\title{
GRAUS DE INTERAÇÃO NO ESPAÇO FÍSICO E VIRTUAL
}

\author{
Paulo Oliveira \\ Universidade Estadual de Campinas
}

A proposta de ensino de língua alemã com suporte virtual, atualmente praticada nos cursos do CEL/Unicamp, ${ }^{1}$ faz parte de um percurso de mais de quinze anos que remonta, destarte, a um período anterior à popularização da internet, tendo, porém, consolidado-se de fato só no início deste século, quando surgiu uma das primeiras plataformas eletrônicas de ensino-aprendizagem, o ambiente TelEduc. ${ }^{2}$ Sua principal característica é o hibridismo convicto e radical, que tenta tirar proveito das melhores características dos materiais em suporte tradicional, como livro e CD, complementando-os com as vantagens oferecidas pelos ambientes virtuais e sua integração à internet.

Os diferentes graus de interação mencionados no título deste trabalho referem-se aos vários formatos de cursos englobados pela proposta, os quais vão desde aulas presenciais (com suporte adicional via plataformas eletrônicas) até a aprendizagem autônoma em regime de autoinstrução, passando por disciplinas semipresenciais, que mesclam esses dois tipos de aula. A perspectiva metodológica também é híbrida, na medida em que procura dar ênfase às habilidades recep-

1 Centro de Ensino de Línguas da Universidade de Campinas.

2 Um histórico abreviado do percurso da área de alemão do CEL/Unicamp no ensino a distância pode ser lido em Oliveira, Wucherpfenning \& Vetter, 2008. 
tivas, notadamente a leitura de textos mais elaborados que aqueles da comunicação pragmática do dia a dia, aproximando-se, dessa forma, da tradição dos chamados cursos instrumentais de leitura, ao mesmo tempo em que trabalha com as habilidades de compreensão e produção oral, aproximando-se da abordagem dita comunicativa.

O hibridismo dos suportes dá-se pela combinação radical de um suporte tradicional (livro texto, manual do estudante e CDs de áudio), que serve como espinha dorsal para a organização dos conteúdos, com materiais adicionais em formato eletrônico, disponibilizados por uma plataforma acessível via internet. O material didático utilizado é a edição brasileira de Blaue Blume, produzida pela Editora da Unicamp, destinada a alunos com interesse científico e cultural na língua alemã, levando do conhecimento zero ao início do patamar intermediário (correspondente ao nível B1 do Quadro Comum Europeu para o Ensino de Línguas). Diferentemente de outros métodos disponíveis no mercado, que têm grande preocupação com a atualidade dos materiais utilizados, Blaue Blume trabalha com textos de cunho histórico, não correndo, assim, o risco de envelhecimento precoce. A dimensão mais contemporânea é dada pelos materiais eletrônicos disponibilizados na plataforma de ensino, estes, sim, carentes e passíveis de constante revisão e atualização (Oliveira, 2006).

O hibridismo de suportes procura também dar espaço a diferentes estilos de aprendizagem e possibilidades de acesso a estruturas de comunicação. Muitos alunos ainda têm certa resistência ao trabalho no ambiente virtual ou têm dificuldades concretas de acesso aos recursos necessários; outros são entusiastas dessa modalidade e/ou trabalham em condições mais propícias. O hibridismo dos cursos procura dar aos alunos mais resistentes à virtualidade, ou que enfrentam dificuldades técnicas, um ponto de referência que lhes dê segurança ao mesmo tempo em que aponta para possibilidades dos novos recursos hoje disponíveis - os quais são explorados até o limite por aprendizes experts nas novas mídias eletrônicas.

Outro aspecto importante do hibridismo de suportes e formas de trabalho diz respeito ao que cada modalidade pode, de fato, ofe- 
recer. Tomemos como exemplo o fomento da produção oral, uma das maiores dificuldades no ensino de línguas em ambiente virtual, posto que, por mais que as tecnologias tenham evoluído, nenhuma fornece a mesma riqueza de detalhes contextuais que a interação face a face em sala de aula. No extremo oposto, está a produção escrita, cujo desenvolvimento é facilitado pelos recursos disponíveis nos ambientes eletrônicos, passando pela possibilidade de consulta rápida a obras de referência e a utilização de ferramentas - como corretores ortográficos cujo potencial de uso, sobretudo, mas não exclusivamente, em níveis básicos, é sistematicamente subestimado -, chegando, por fim, às enormes possibilidades de registro para posterior acesso e discussão coletiva. A Figura 1 apresenta sinteticamente os diferentes espaços utilizados na proposta geral, tendo como plataforma virtual o ambiente TelEduc. Nesse curso, os espaços e momentos são interligados por projetos individuais e coletivos (Oliveira, 2003a e 2003b).

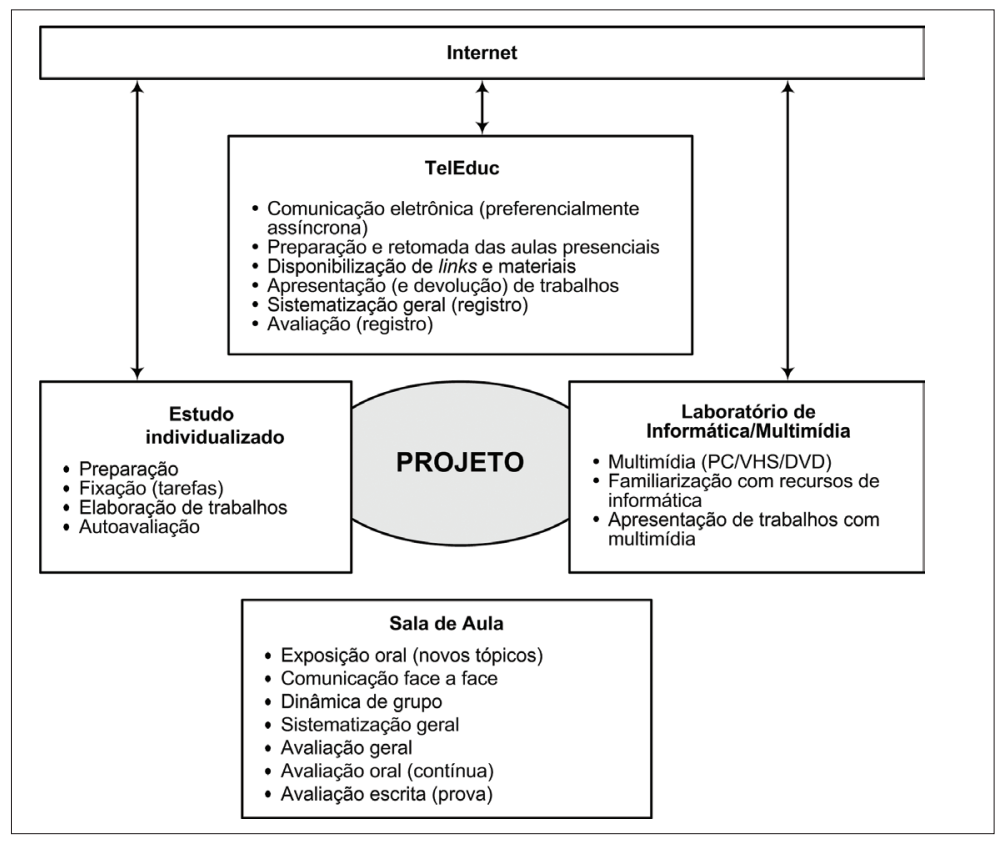

Figura 1 


\section{Níveis de participação}

Dentro do conceito geral esboçado anteriormente e sintetizado na Figura 1, o ensino do curso de alemão semipresencial é o que melhor permite apresentar os diferentes graus de interação, uma vez que o equilíbrio e a sinergia entre as formas de trabalho é maior. Nesse método, combina-se a interação face a face da sala de aula (um encontro semanal) com a comunicação virtual na plataforma eletrônica, conforme ilustrado na Figura 2.

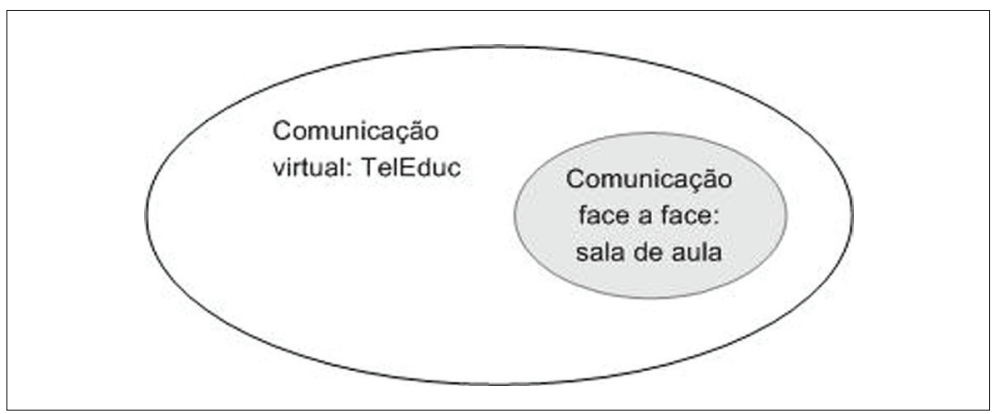

Figura 2

Para atender o grande contingente de alunos que não consegue vagas em disciplinas regulares (cerca de 150 a 200 por semestre nos níveis iniciais), foi criada a modalidade do ouvinte virtual, que permite aos não inscritos acompanharem, na plataforma, os trabalhos feitos pelos alunos inscritos nas disciplinas regulares. Eventualmente, os estudantes não matriculados podem ser ouvintes nas sessões presenciais (dependendo da liberação de vagas, ou melhor, do espaço físico) e, depois, ingressar nos níveis subsequentes mediante testes de classificação (Figura 3).

Dando um passo adiante nessa abertura para outros aprendizes, foram disponibilizados os mesmos materiais no Portal de ensino aberto da Unicamp para interessados em autoestudo, sobretudo aqueles em áreas de difícil acesso ou com dificuldade de formação de grupos de trabalho com ou sem orientação de tutor local (Figura 4). 


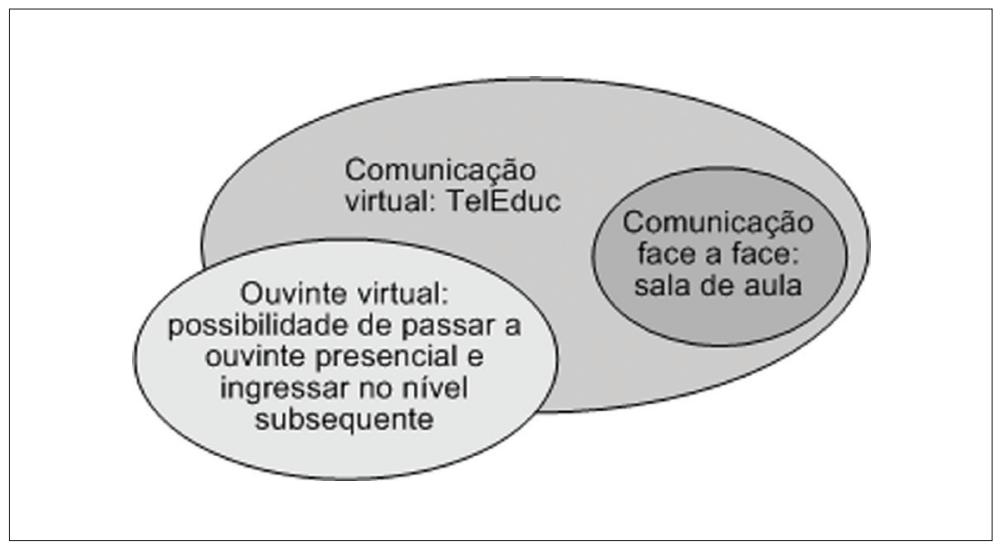

Figura 3

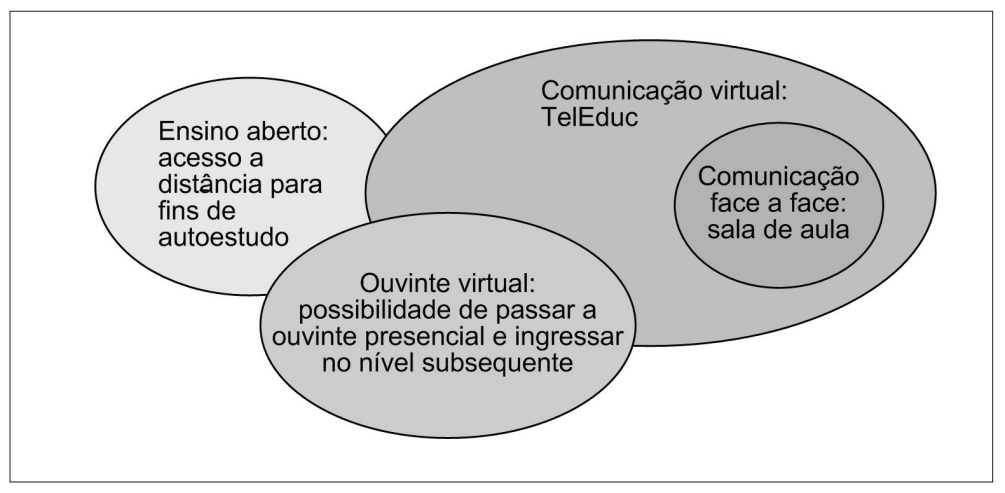

Figura 4

A ideia inicial era formar, em diferentes instituições, núcleos de trabalho com a mesma metodologia que pudessem compartilhar novas experiências e materiais, estabelecendo, então, uma rede institucional de compartilhamento de projetos. Tal proposta, no entanto, não encontrou o eco necessário em outras instituições que adotaram Blaue Blume como material didático em cursos regulares - provavelmente por falta de pessoal e técnica para trabalhar no espaço virtual, ou melhor, pela falta de cultura de ensino-aprendizagem em ambientes eletrônicos (principalmente em redes inte- 
rinstitucionais). Parte dos alunos dessas instituições, no entanto, tem acessado os materiais disponibilizados nos servidores da Unicamp.

A proposta de disponibilizar esses materiais no Portal do ensino aberto foi alterada em 2008 para dar conta da mudança de plataforma de suporte, que passou a utilizar o Moodle, após um projeto-piloto, no final de 2007, que durou um semestre. Feita a migração, continuam existindo diferentes níveis de participação, porém sem a expectativa de formação de uma rede institucional mais ampla - por ora. $\mathrm{O}$ acesso de ouvintes virtuais agora se dá na condição de visitantes em cursos abertos. Os alunos regularmente matriculados acessam suas disciplinas como usuários registrados no endereço http://moodle.ead.unicamp.br.

\section{Concepção dos cursos no ambiente Moodle}

A migração do TelEduc para o Moodle deu-se em função da necessidade de aumentar a escala de atendimento, sobretudo de ouvintes virtuais. Até então, todas as atividades desenvolvidas na plataforma eletrônica demandavam correção individual do professor, inviabilizando a ampliação do projeto para atender o público externo sem restringir-se à disponibilização de links e materiais sem necessidade de correção. Procurou-se, dessa forma, integrar exercícios com correção automática ainda no TelEduc. No entanto, mesmo que o ambiente forneça recursos destinados a esse fim (ferramenta Exercícios), a diversidade de opções disponíveis mostrou-se bastante limitada. As maiores dificuldades encontradas, porém, diziam respeito a questões de economia na elaboração dos exercícios e, principalmente, de confiabilidade (dos formatos com correção automática, apenas as questões de múltipla escolha não causaram problemas de cálculo e integralização da nota). Tendo isso em vista, o Centro de Computação da Unicamp (CCUEC) disponibilizou para a Área de Alemão do CEL, no segundo semestre de 2007, uma instância do Moodle para estudo piloto (Oliveira, 2007). A experiência foi bem-sucedida e serviu de base para a migração de plataformas já no início de 2008. 
Na segunda metade do ano, com a implantação de um novo servidor de EAD na Unicamp, o Moodle passou a ser disponibilizado também para o restante da universidade, como plataforma alternativa ao TelEduc, para docentes com necessidade de recursos diferenciados. No momento, a perspectiva é de migração para o ambiente Sakai, dentro do projeto Tidia, financiado pela Fapesp. No caso do curso de alemão, a alteração dependerá da disponibilidade, na nova plataforma, de recursos compatíveis com os disponíveis no Moodle. ${ }^{3}$

A seleção dos recursos utilizados na nova plataforma procurou não apenas explorar outras possibilidades, mas também preservar os princípios norteadores da proposta geral, tal como tinham sido concebidos para utilização no TelEduc. Optou-se pela estrutura modular, contemplando a progressão em unidades curtas do material didático (Blaue Blume) e mantendo o paralelismo com as unidades tratadas nas diferentes disciplinas do catálogo da graduação na Unicamp. Isso levou à criação de seis níveis, cada um deles atendendo nove unidades no material didático. Os cursos abertos utilizam os materiais elaborados para os cursos regulares, à exceção de atividades colaborativas que pressupõem o registro no ambiente, como os fóruns e wikis, que funcionam de maneira integrada dentro da proposta dos cursos. Mesmo assim, os visitantes dos cursos abertos têm acesso às atividades de escrita propostas para os wikis, na forma de comentários dessas atividades, com exemplos de resolução. A tela a seguir fornece uma visão geral dos recursos utilizados e da estruturação dos módulos (Figura 5).

À esquerda, foram agrupados links de acesso rápido ao cronograma do curso e atalhos para as diferentes atividades. À direita,

3 No departamento de Alemão do CEL/Unicamp, também está em curso um projeto piloto de utilização da plataforma DUO, da Universidade de Munique, em associação com o material didático Schritte international. Até o momento, foram realizados dois semestres do projeto, com financiamento integral do Serviço Alemão de Intercâmbio Acadêmico (DAAD), no primeiro semestre, e apoio do Centro Acadêmico da Faculdade de Engenharia Elétrica e da Computação. Os resultados por ora disponíveis apontam uma maior adequação, para o contexto brasileiro, da combinação Moodle + Blaue Blume (Oliveira, Wucherpfennig \& Vetter, 2008; Wucherpfennig \& Vetter, 2008; Vetter \& Moura, 2008). 
agrupam-se o bloco Administração e os recursos de comunicação no ambiente virtual. No bloco central, vê-se o Módulo de Apresentação, com informações gerais sobre o ambiente e o curso, seguido de um módulo específico para cada unidade nos materiais didáticos. Há três tipos de fórum: um de avisos gerais (sem possibilidade de postagem por parte dos alunos), um fórum do curso (com postagem de todos os participantes) e diferentes fóruns por grupo de trabalho. Além disso, há links para páginas com informações gerais sobre o funcionamento do Moodle e do próprio curso e para um repositório de recursos externos disponíveis na internet (Informações gerais: material de apoio). Para possibilitar a atualização e permitir o acesso a partir de diferentes cursos, essa página foi hospedada em servidor externo. Com isso, basta manter atualizada a página de índice nesse servidor para que todos os cursos (regulares e abertos) estejam atualizados. Trata-se, basicamente, de uma lincoteca com páginas sugeridas por professores e alunos dos diferentes cursos.

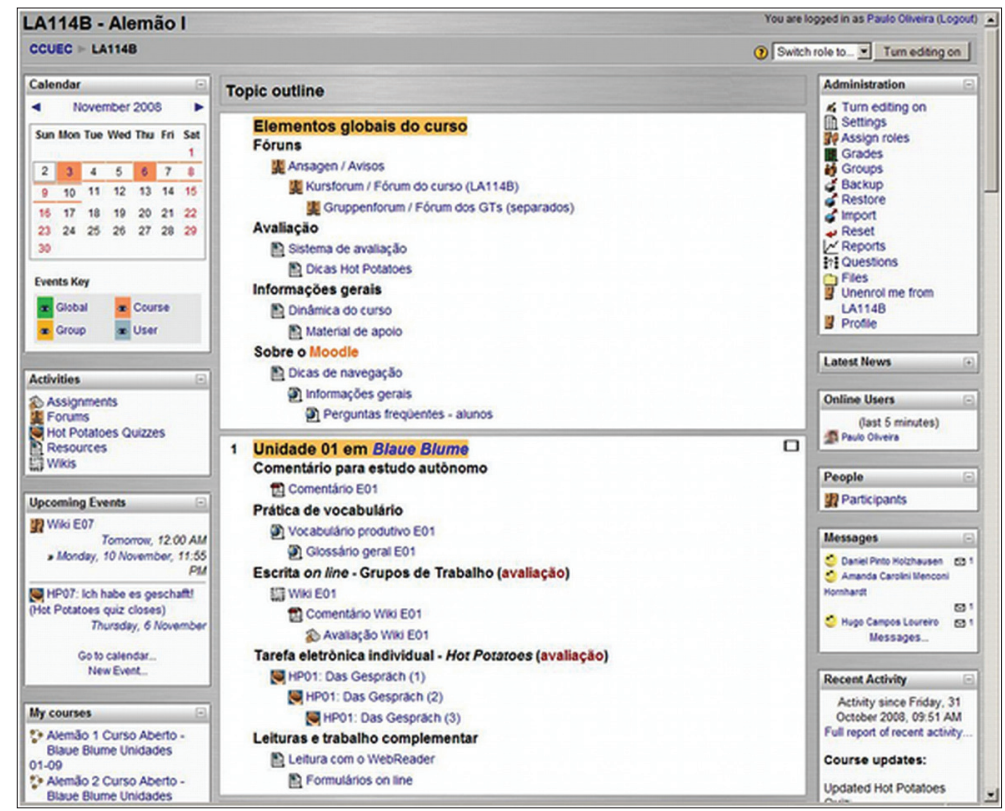

Figura 5 
Nos módulos específicos de cada unidade, a estrutura unificada sugere determinada sequência de trabalho. Primeiramente, tem-se um Comentário da Unidade em PDF. Nas discussões sobre o material didático de base, havia surgido a restrição de que Blaue Blume não disponibilizaria um manual do professor, como outros materiais didáticos para ensino de alemão existentes no mercado. Para suprir essa lacuna e avançar rumo à aprendizagem autônoma em regime de autoestudo, os Comentários das Unidades servem como manual do aluno, podendo também ser utilizados por professores, e dão dicas de trabalho e explicações complementares, sendo muitas delas transcrição dos tópicos tratados na lousa nos cursos regulares. Aqui é feito, dentre outros, um trabalho comparativo entre alemão e português, levando-se em conta as dificuldades típicas do público-alvo, consolidadas na prática didática na Unicamp.

O tópico seguinte, Prática de Vocabulário, fornece link direto para fichas no formato de flash cards disponibilizadas no servidor WordChamp, que possibilita o trabalho colaborativo em diversas línguas. Essas fichas de vocabulário são integradas na base de dados da ferramenta WebReader, que possibilita a leitura on-line de textos eletrônicos, como dicionário pop up. Usuários registrados no site podem editar os vocábulos disponíveis, mediante inclusões, exclusões e correções. Em alguns casos, textos mais complexos de Blaue Blume são disponibilizados no Moodle em formato htm, justamente para possibilitar (sobretudo aos ouvintes virtuais) uma leitura mais detalhada - sempre após o trabalho com técnicas e estratégias de leitura não pontual. No momento, a base de dados de alemão/português do WebReader recorre, principalmente, às fichas elaboradas para uso com Blaue Blume.

A Escrita Online é feita em wiki, que substituiu o portfólio de grupo usado no TelEduc. Além de permitir o trabalho colaborativo, essa ferramenta também identifica as contribuições de cada membro do grupo, possibilitando ao professor algum controle sobre a dinâmica de trabalho de cada grupo. Como não há previsão de atribuir notas aos wikis no Moodle, isso é feito pelo recurso Atividade Off-line, que permite, inclusive, variar as notas dentro do próprio 
GT, no caso de não participação de algum membro, ou de distribuição muito desigual de trabalho - isso tem se mostrado muito útil, em função da incipiente cultura de trabalho colaborativo. Uma vez encerrado o prazo de postagem (o que pode ser definido pelo recurso Calendário, usando o respectivo wiki como título do evento), as tarefas são corrigidas pelo professor e enviadas anonimamente, como comentário geral do wiki. Com isso, os alunos têm acesso não só à sua produção individual, como também à do restante da turma. No caso de dificuldades generalizadas com determinado tópico, esse é retomado em sala de aula pelo professor.

Ao final de cada unidade, os alunos devem rever a matéria fazendo atividades no formato Hot Potatoes, com correção automática. As grandes vantagens desse formato, com módulo específico integrado ao Moodle, são a facilidade de elaboração, o número de formatos disponíveis e a possibilidade de integrar facilmente recursos externos, como textos adicionais, áudio e vídeo. O módulo específico está completamente integrado ao sistema de cálculo e registro de notas do Moodle, que foi bastante aprimorado nas versões mais recentes do ambiente (até 1.9.3+). Com isso, superam-se os gargalos impostos pelo TelEduc na utilização de tarefas com correção automática e tem-se um ambiente mais amigável do que os recursos ora disponíveis tanto no ambiente Sakai quanto na plataforma DUO. A Figura 6 traz exemplo de utilização do Hot Potatoes com recursos externos integrados.

Nessa tarefa, utiliza-se um link para vídeo disponível na internet, com tocador integrado. Abaixo da figura, à esquerda, há um texto explicativo com a transcrição do diálogo. Do lado direito, há perguntas (de múltipla escolha) relativas à tarefa que tratam do complexo das partículas modais em alemão e de sua importância para a linguagem oral. Após o término da tarefa, o Hot Potatoes envia os resultados ao Moodle, que os registra em sua base de dados, possibilitando o cálculo de médias ponderadas, que podem ser revistas a qualquer momento, sem interferência nos dados brutos. No caso de problemas de comunicação, tentativas frustradas podem ser apagadas pelo professor. Havendo necessidade, a própria 
tarefa pode ser revisada, sem interferir na programação geral do curso. Tal possibilidade revela-se extremamente útil, sobretudo no caso de problemas de elaboração, os quais, uma vez detectados, podem ser sanados pelo docente, que disponibiliza uma versão corrigida para dar continuidade ao trabalho dos alunos. ${ }^{4}$

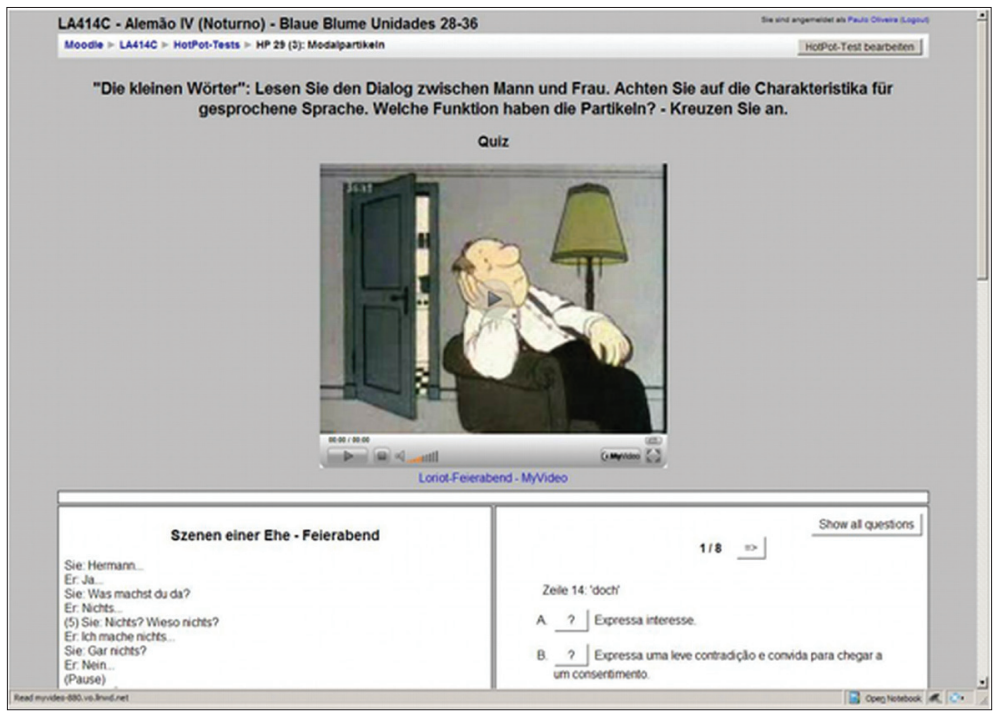

Figura 6

Finalizando o trabalho de cada unidade, tem-se uma coleção de links de materiais que tratam dos tópicos abordados e servem para aprofundamento da matéria individualmente (Leituras e Trabalho Complementar). Parte desses materiais fica gravada em repositório externo, mas na própria Unicamp, não demandando maior trabalho de manutenção. Outra parte, no entanto, está disponível apenas em servidores externos à universidade e demanda, portanto, manutenção contínua para verificação da atualidade dos links e

4 Para maiores detalhes sobre o uso integrado de wikis e Hot Potatoes no ambiente Moodle, ver Oliveira, 2008. 
disponibilidade dos materiais. Apesar dessa restrição, trata-se de importante complemento às atividades do curso, na medida em que possibilitam não somente atender aos diferentes estilos cognitivos, necessidades e interesses específicos dos aprendizes, como também incentivar a navegação na internet à procura de recursos úteis para a aquisição do idioma. Esse também é um dos objetivos explícitos do curso e fundamento de suas premissas mais gerais: a passagem do estudo dirigido para uma autonomia cada vez maior na aprendizagem.

Nos cursos regulares, um último módulo é usado para fazer o Balanço do Curso, com registro da frequência e das avaliações orais nos diferentes períodos. Em alguns casos, são postados aqui materiais para trabalhos com temas transversais, que vão além de unidades específicas no material didático de suporte (Figura 7).

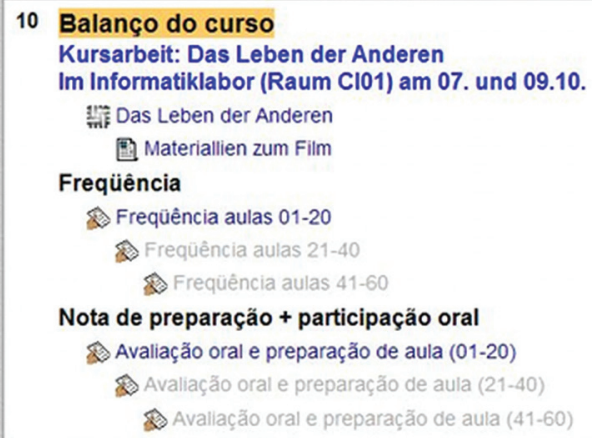

Figura 7

Nesse caso, vê-se que o trabalho do curso baseia-se no filme $A$ vida dos outros, ${ }^{5}$ que trata de questões políticas na antiga Alemanha Oriental, tópico abordado na unidade inicial da disciplina (Alemão $\mathrm{V}$ : Blaue Blume, unidade 37). Aqui, uma vez mais, coloca-se a ques-

5 Das Leben der Anderen. Direção de Florian Hencklen von Donnersmarck. Alemanha, 2006. 
tão dos diferentes níveis de participação, dependendo das diversas modalidades de trabalho. Para o ouvinte virtual ou em sistema de autoestudo, os materiais disponibilizados podem servir como dica de trabalho, e os comentários nos wikis produzidos nas disciplinas regulares servem de modelo, ou exemplo de possíveis execuções da tarefa - no que tiverem de bem ou malsucedido. Para os alunos matriculados de disciplinas regulares, o envolvimento é certamente maior. Além de assistirem ao filme, têm de elaborar um texto escrito baseado em um catálogo de perguntas formulado pelo professor (roteiro de escrita). Após a correção desse texto, disponibilizada no comentário do wiki, é feita uma apresentação oral em sala de aula no final do semestre. Com base nas apresentações dos diferentes grupos de trabalho, é feita, então, uma discussão sobre o filme. Aqui, tem-se uma atividade integrada com as diferentes habilidades: compreensão oral em um formato propício (filme legendado); produção escrita baseada em roteiro formulado em alemão e lançando mão de outros recursos, como textos complementares, dicionários eletrônicos e corretores ortográficos, etc.; formulação de texto escrito em alemão e discute-se sua correção pelo professor; e apresentação oral, também em alemão. No caso em pauta, agregou-se uma componente adicional de trabalho autônomo, na medida em que os GTs trabalharam no laboratório de informática na ausência do professor (que estava participando de evento científico).

Para sintetizar esta breve apresentação de um projeto de longo prazo, podemos concluir que temos hoje, na Unicamp, um modelo já bastante consolidado de ensino de alemão com suporte em ambientes eletrônicos de aprendizagem, como parte de uma abordagem convicta e radicalmente híbrida, que continua a explorar as vantagens das mídias tradicionais e leva em conta dificuldades técnicas e resistências culturais por parte de seu público-alvo - aprendizes brasileiros com interesse acadêmico e cultural na língua, sobretudo (mas não exclusivamente) no contexto universitário. $\mathrm{O}$ trabalho de disponibilização de materiais complementares no ambiente virtual encontra-se bastante adiantado, devendo chegar ao fim do primeiro ciclo em meados de 2009, quando, então, passará 
por um processo de revisão mais sistemática, complementar à revisão constante feita ao longo do percurso. A perspectiva é de que, com a crescente popularização dos recursos eletrônicos e a maior familiaridade do público com tais recursos, que tendem a ficar cada vez mais intuitivos, o papel do componente virtual ganhe maior destaque. Mas, certamente, continuaremos, também no futuro, a explorar as mídias tradicionais e o ambiente de aprendizagem presencial. Uma mescla saudável entre o velho e o novo, entre a presença e a distância, parece ser um bom ponto de equilíbrio na busca pela aprendizagem democrática e efetiva, também no ensino de línguas estrangeiras.

\section{Bibliografia}

OLIVEIRA, P. Uso do TelEduc no ensino de línguas. Comunicação no Centro de Computação(CUEC/Unicamp), 28/5/2003a. Disponível em <http://www.ccuec.unicamp.br/treinamentos/index_html?foco2 $=$ Palestras/ead/768458\&focomenu=Palestras $>$. . Encontro de professores usuários do ambiente TelEduc. Comunicação no Centro de Computação (CCUEC/Unicamp), 26/11/ 2003b. Disponível em <http://www.ccuec.unicamp.br/ead/index_html?foco2=Eventos $/ 75574 / 943135 \&$ focomenu $=$ Eventos>.

- À procura da flor azul no ensino da língua alemã. In: Projekt, v.44, p.13-23, 2006. Disponível em <http://www.unicamp. $\mathrm{br} / \sim$ paulocel/leituras/Flor_azul.pdf $>$.

- Integrando recursos e demandas com o Moodle. Comunicação no Centro de Computação (CCUEC/Unicamp), 5/9/2007. Disponível em <http://www.cameraweb.unicamp.br/acervo/ 2007.html>.

. Hot Potatoes und Wiki im Moodle. VII Congresso Brasileiro de Professores de Alemão. Rio de Janeiro: Abrapa, 2008. Disponível em <http://www.unicamp.br/ paulocel/ HP_Wiki_Moodle. pdf $>$. 
; WUCHERPFENNIG, N.; VETTER, A. Alemão para universitários: formas híbridas. Cadernos de Letras (Rio de Janeiro), v.24, p.59-84, 2008. Disponível em <http://www.unicamp.br/ paulocel/leituras/ale_uni_rev-fin.pdf $>$.

VETTER, A.; MOURA, S. F. Q. de. Abschlussbericht über die Extensivkurse basis-deutsch und Blaue Blume/Moodle im 1. Semester 2008. Campinas: Unicamp. Relatório técnico encaminhado à Unicamp e ao DAAD.

WUCHERPFENNIG, N.; VETTER, A. Zum Einsatz von Internetplattformen im universitären DaF-Unterricht - am Beispiel von Moodle und DUO. VII Congresso Brasileiro de Professores de Alemão. Rio de Janeiro: Abrapa, 2008. 



\title{
INTERESSES E NECESSIDADES DE USO DA INTERNET DA PERSPECTIVA DE ALUNOS DE LETRAS - ESPANHOL
}

\author{
Mônica Ferreira Mayrink \\ Universidade de São Paulo
}

As mais diversas instituições de ensino do país - da educação básica ao ensino superior - sentem-se, hoje, impulsionadas a revisar suas metodologias, projetos pedagógicos e currículos, pois perceberam a necessidade de incorporar neles o uso de novas tecnologias da informação e comunicação (NTICs), garantindo, principalmente, o acesso e uso de computadores conectados à internet.

Em função desse panorama que vai se configurando na educação brasileira, com reflexos imediatos na formação de professores, tenho me preocupado com o espaço que as NTICs têm ocupado nos cursos de Letras - Espanhol, minha área de atuação, e também com a forma como essas tecnologias estão sendo levadas, por docentes recém-formados, para a sala de aula das escolas da educação básica. ${ }^{1}$

Julgo importante, também, conhecer como os alunos de Letras - futuros professores de espanhol - utilizam as NTICs e, especialmente, a internet, pois essa informação pode contribuir para a defi-

1 No artigo "As múltiplas realidades do uso de tecnologias no ensino de espanhol da rede pública” (Mayrink, 2009), faço levantamento inicial sobre a forma como as tecnologias estão sendo incorporadas à prática dos professores de espanhol da rede pública do Estado de São Paulo. 
nição de projetos e propostas de formação inicial de professores mais afinados com suas necessidades e interesses.

Este artigo relata uma pesquisa feita com quarenta alunos do curso de Letras - Espanhol da Faculdade de Ciências e Letras, campus de Araraquara (FCLAr), da Universidade Estadual Paulista (UNESP), que responderam a um questionário ${ }^{2}$ cujo objetivo era reunir informações relacionadas às preferências e necessidades dos estudantes quanto ao uso da internet. ${ }^{3}$

A fim de discutir os resultados da pesquisa, parto de uma breve reflexão sobre o papel que as tecnologias vêm assumindo na área educacional. A seguir, detalho o contexto em que essa pesquisa foi desenvolvida e descrevo o procedimento de coleta de dados. Discuto, na sequência, as análises relativas ao uso que os participantes fazem da internet e proponho algumas reflexões iniciais a respeito dos desafios que se apresentam na formação inicial de professores, no que se refere à utilização de NTICs.

\section{Sociedade e educação em processo de transformação}

É fato que vivemos em uma sociedade marcada por um avanço tecnológico vertiginoso que estabelece, segundo Giddens (1997), uma interconexão global cujas consequências são mudanças nas relações de tempo e espaço. Esse avanço origina, também, novas formas de comunicação e veiculação de informação, implicando, necessariamente, um novo entendimento dos processos de aprendizagem e de construção de conhecimento. No cerne dessa questão, está o indiscutível papel que as NTICs vêm exercendo nas mais

2 O questionário será apresentado na seção "Contexto da pesquisa".

3 O questionário foi elaborado em conjunto com Mariana Funes, aluna do curso de Letras - Espanhol, da Faculdade de Ciências e Letras da UNESP - Araraquara. No período em que fui docente nessa universidade, Mariana desenvolveu, sob minha orientação, o projeto de estágio departamental intitulado "Pesquisa de sites de interesse para a aprendizagem de língua espanhola". 
diversas esferas de nossa vida, aspecto que tem sido objeto de inúmeras pesquisas.

A quarta edição da Pesquisa sobre o uso das Tecnologias da Informação e da Comunicação no Brasil - TIC domicílios e TIC empresas $2008^{4}$ (Barbosa, 2009) apresenta um mapeamento da posse e do uso das TICs em nosso país, focando três dimensões fundamentais: os usuários, os domicílios e as empresas.

No uso domiciliar, a pesquisa identificou que aumentou "o uso e a posse de TICs em todo o território nacional, alcançando 34\% da população de efetivos usuários da internet e, somente na zona urbana, esse indicador já ultrapassou os 50 milhões de usuários da rede mundial de computadores" (p.10). Já na pesquisa TIC empresas 2008, constatou-se expressivo crescimento no utilização das redes sem fio e o fortalecimento do processo de terceirização da mão de obra especializada em TI. A análise ainda revela que o computador e a internet

consagram-se como poderosas ferramentas no universo das TICs, mas ainda temos um longo caminho a ser percorrido pelo Governo e pela sociedade para alcançar a universalização dessas tecnologias, propiciando não só o acesso à era digital, mas a capacitação digital dos cidadãos brasileiros. (Barbosa, 2009, p.10)

Almeida (2003), por sua vez, destaca o crescente avanço no uso de TICs nas mais diversas áreas do conhecimento, gerando mudanças e abrindo novas possibilidades para a educação. De fato, de acordo com a pesquisa mencionada, dentre as atividades realizadas na internet, um dos destaques é o crescimento daquelas relacionadas a treinamento e educação (tarefas e pesquisas escolares; busca de informações sobre cursos de graduação, pós-graduação e extensão; busca de informações sobre disponibilidade de livros e downloads de cursos; participação em cursos on-line). Entre 2005 e 2008, elas cresceram dezesseis pontos percentuais, passando de $56 \% \mathrm{em}$ 2005 para $72 \%$ em 2008, conforme ilustra o gráfico:

4 Pesquisa disponível em www.cetic.br. 


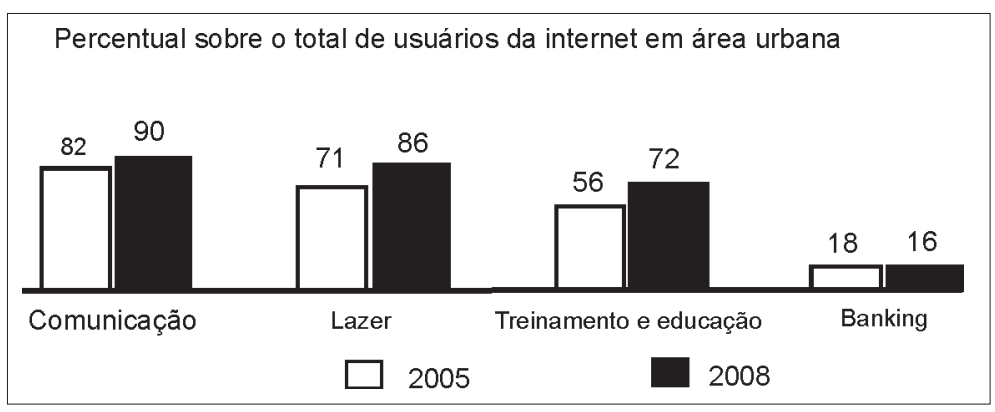

Gráfico 1 - Atividades desenvolvidas na internet (\%). Fonte: Barbosa, 2009, p.149.

Como pode-se observar no gráfico, todos os tipos de usos da internet apresentaram crescimento entre 2005 e 2008, exceto os serviços de e-banking, que permaneceram constantes nesse período.

Esse avanço pode ser explicado sob a ótica de Brunner, para quem

A revolução tecnológica da informação e das comunicações, uma das fontes das interconexões globais, representa, por si mesma, uma força transformadora de quase todos os âmbitos de atividade social: o trabalho e a produção, o lar e o consumo, o comércio, o entretenimento, a socialização e transmissão de saberes, a organização das empresas e dos Estados, a oferta de serviços e a circulação de todo tipo de dados e conhecimentos. (Brunner, 2004, p.22)

Diante desse novo panorama, cria-se um paradoxo na utilização dos recursos tecnológicos para fins educacionais, pois, ao mesmo tempo que sabemos que as NTICs, particularmente a internet, podem contribuir para o aprimoramento intelectual e profissional dos indivíduos, perguntamo-nos se eles estão, de fato, preparados para assumir uma postura seletiva e crítica diante de informações que encontram na rede. Para Brunner,

O problema para a educação na atualidade não é onde encontrar a informação, mas como oferecer acesso a ela sem exclusões e, ao mesmo 
tempo, aprender e ensinar a selecioná-la, avaliá-la, interpretá-la, classificá-la e usá-la. (Ibidem, p.24)

O desafio que se coloca, portanto, nas mais diversas esferas e níveis de ensino, é o de contribuir para que os alunos assumam uma postura adequada no uso da internet, tomando consciência de que $o$

conhecimento não viaja pela internet. Construí-lo é uma tarefa complexa, para a qual não basta criar condições de acesso à informação [...]; para transformar a informação em conhecimento, exige-se - mais que qualquer outra coisa - pensamento lógico, raciocínio e juízo crítico. (Ibidem, p.97)

Essa postura diferenciada do usuário da internet também é objeto de reflexão de Gomes (2002, p.121), para quem a utilização dos novos recursos comunicacionais e informáticos não deve ser encarada "como mais uma novidade, mas como uma possibilidade para que alunos e professores assumam o papel de sujeitos críticos, criativos e construtores de seu próprio conhecimento".

Consciente de que, atualmente, as NTICs são ferramentas imprescindíveis para o constante aprimoramento intelectual e profissional dos indivíduos e de que é possível ter acesso a conhecimentos que outrora pareciam inatingíveis, dadas as limitações geográficas de acessibilidade ou de tempo, penso que é necessário criar condições para a formação de profissionais (neste caso, de professores de espanhol) críticos em relação à tecnologia e, ao mesmo tempo, capazes de lidar com ela.

A fim de formar usuários ativos e críticos, é fundamental propiciar condições para que os alunos do ensino superior - futuros professores - possam identificar, localizar, selecionar e tratar de forma adequada a informação de que necessitam para as diferentes atividades de seu cotidiano. Conforme afirma Giusta (2003, p.33), trata-se de uma visão de aluno como indivíduo "dotado de autonomia, capaz de organizar internamente informações retiradas do mundo 
físico e cultural. Isso equivale a afirmar que o aluno é sujeito ativo no processo ensino/aprendizagem".

Nessa perspectiva, conforme mencionei anteriormente, instituições de ensino dos mais diversos níveis e contextos estão tomando a iniciativa de incorporar, em seus cursos, o uso ativo de NTICs. Esses esforços têm apresentado repercussões no âmbito interno das disciplinas presenciais já existentes - a utilização dos recursos tecnológicos como um instrumento adicional de mediação da aprendizagem -, ou, ainda, na criação de disciplinas oferecidas nas modalidades semipresencial ou a distância. Essa oferta, no entanto, deve obedecer às normas vigentes da Portaria 4.059/2004, artigo 1, parágrafo 2ㅜㅡ, que determina: "poderão ser oferecidas as disciplinas referidas no caput, integral ou parcialmente, desde que a oferta não ultrapasse $20 \%$ (vinte por cento) da carga horária total do curso". ${ }^{5}$

As novas tecnologias, no ensino, surgem como alternativa para atender às necessidades geradas pela sociedade neste início de século. Especificamente no ensino superior - na área de formação de professores -, o trabalho com as novas tecnologias cumpre, também, o desafio de atender às demandas da sociedade no que se refere a sensibilizar o aluno para a docência virtual. Entende-se aqui o importante papel da universidade na produção de conhecimento que garanta a apropriação, por sua comunidade, dos recursos tecnológicos disponíveis, de uma perspectiva crítica. Isso significa, certamente, criar a possibilidade de desenvolvimento de processos reflexivos que permitam que o aluno compreenda seu processo de aprendizagem e de construção de significados.

É preciso, pois, considerar que, para poder participar da cultura tecnológica, o aluno precisa desenvolver certas competências e habilidades e, para poder participar da sociedade de informação, necessita saber conviver com o ritmo constante de mudanças, ter a capacidade de refletir, analisar, buscar novas informações, além de saber aprender a aprender.

5 BRASIL, Ministério da Educação. Portaria 4.059, de 10/12/2004. 


\section{Contexto da pesquisa}

Esta é uma pesquisa de campo que se apoiou na análise de um questionário respondido por quarenta alunos do curso de Letras - Espanhol, da FCLAr - UNESP, no segundo semestre de 2008. Conforme mencionei, o objetivo do questionário era reunir informações relacionadas às preferências e necessidades dos estudantes quanto ao acesso a sites na internet. No momento em que a pesquisa foi realizada, os dados interessavam, particularmente, por seu potencial de contribuir para o desenvolvimento de três projetos em andamento na FCLAr, na área de Espanhol, vinculados ao grupo de pesquisa Linguagem, Educação e Virtualidade (LEV), ${ }^{6}$ pois trariam informações relevantes para a implementação de cursos on- line e elaboração de sites para professores e alunos do idioma.

As duas primeiras perguntas do questionário tinham o objetivo de reunir dados sobre o contexto de aprendizagem dos estudantes participantes:

1. O espanhol será sua língua de formação na sua graduação?

$$
\text { ( ) } \operatorname{Sim}(\text { ) Não }
$$

2. Sendo a resposta anterior positiva, escreva, sinteticamente, por que você escolheu habilitar-se em espanhol e quais são as expectativas quanto à sua futura carreira.

A pergunta era relevante por haver, no curso de Letras da FCLAr, a possibilidade de o aluno cursar, no primeiro ano, duas

6 O grupo de pesquisa é coordenado por mim e pela professora dra. Ucy Soto (UNESP - FCLAr). Os projetos em questão são: Oficinas virtuais na formação inicial de professores de espanhol: espaço de reflexão e construção de competências linguísticas e pedagógicas (desenvolvido sob minha coordenação durante o período em que integrei o quadro docente da UNESP); Ambiente híbrido para a aprendizagem (blended learning) de espanhol língua estrangeira: construção de uma proposta didático-pedagógica (coordenado pela professora Ucy Soto); e Implementação de interface virtual para professores de língua espanhola (desenvolvido por nós duas). 
línguas estrangeiras, sendo que apenas uma delas seria sua língua de formação. Ao tabular os dados recolhidos por meio dessas duas questões, observei que, dos quarenta alunos que responderam ao questionário, 29 escolheram a graduação em espanhol e outros 11 alunos estudariam essa língua somente durante um ano.

Quanto ao motivo que os levou a escolher o curso de Letras Espanhol como formação universitária, há uma variedade de justificativas. ${ }^{7}$ As três razões mais mencionadas foram: gosto pessoal pelo idioma (16 alunos); interesse em lecionar a língua futuramente (12 alunos); e reconhecimento do amplo campo de trabalho que está se abrindo para o graduado em Letras - Espanhol (9 alunos).

As demais perguntas incorporadas ao questionário diziam respeito, especificamente, ao uso da internet.

\section{Uso da internet por alunos de Letras - Espanhol}

A pesquisa realizada com alunos do curso de Letras - Espanhol da FCLAr compreende somente o mapeamento inicial do uso que fazem da internet. A primeira informação coletada pelo questionário corresponde à frequência de acesso à rede. Os dados apontam que vinte alunos (50\%) utilizam a internet todos os dias e apenas um diz consultá-la várias vezes por dia. Outros participantes da pesquisa informaram que usam a internet com menor frequência, com cinco acessos por semana ou menos: um aluno usa a internet cinco dias por semana; treze alunos consultam a rede três ou quatro vezes por semana; e cinco estudantes apenas uma ou duas vezes por semana. Os números parecem mostrar que o acesso à rede de informações é inferior ao que se esperaria, mas é possível que essa constatação se explique pelo fato de que muitos estudantes do curso de Letras da FCLAr têm acesso restrito a computadores com conexão à internet, pois em suas residências não dispõem de computador,

7 Como se tratava de uma pergunta aberta, os alunos podiam mencionar mais de um motivo para a escolha da graduação em espanhol. 
3. Com que frequência você costuma utilizar a internet?

( ) vezes por semana.

( ) Todos os dias.

( ) Várias vezes durante o dia.

4. Com que objetivos você utiliza a internet? Enumere de 5 (uso mais frequente) a 1 (uso menos frequente):

( ) Para acessar meus e-mails e Orkut e como meio de comunicação pessoal.

( ) Uso a internet como ferramenta de trabalho.

( ) Utilizo a internet em minhas pesquisas acadêmicas.

( ) Costumo usar a internet para divertir-me: ouvir música, assistir a vídeos, jogar.

( ) Utilizo a internet para informar-me sobre as notícias da atualidade.

Indique aqui outros usos que faz da internet, caso eles não tenham sido incluídos acima:

5. Pensando nos conteúdos que você gostaria de encontrar em um site específico para professores e alunos de espanhol, indique, na lista abaixo, quais considera (3) muito interessantes, (2) interessantes ou (1) pouco interessantes:

( ) Conteúdo relacionado à aprendizagem da língua espanhola, com exercícios - escritos ou de áudio - para aprimorar seus conhecimentos na língua.

( ) Conteúdo relacionado à literatura espanhola e hispano-americana.

( ) Conteúdo acadêmico - possibilidade de contato, intercâmbio, cursos, acesso às pesquisas, etc. - de universidades situadas em países de língua espanhola.

( ) Conteúdo informativo de diversos países de língua espanhola (política, cultura, economia, atualidades, etc.).

( ) Conteúdo relacionado a entretenimento (filmes, livros, música, programas de televisão, programas de rádio, etc.).

( ) Conteúdo relacionado a informações sobre o "mundo dos famosos" e afins, nos países de língua espanhola.

( ) Outros: 
dependendo, principalmente, do laboratório de informática da universidade. $^{8}$

Quanto aos objetivos que levam os alunos a usar a internet, percebe-se que o acesso aos e-mails e Orkut e a comunicação pessoal constitui o motivo mais frequente ( 25 alunos atribuíram notas 5 ou 4 a essa opção, o que indica a utilização muito ou bastante frequente). A segunda razão que os leva a usar a internet com muita ou bastante frequência é a realização de pesquisas acadêmicas (opção indicada por 19 dos 40 alunos). O uso da internet como ferramenta de trabalho foi indicado por 15 alunos, número muito próximo aos 14 alunos que afirmaram utilizar a rede frequentemente para diversão (ouvir música, assistir a vídeos, jogar). Apenas sete participantes indicaram o uso constante da internet para ler notícias da atualidade. ${ }^{9}$

No outro extremo, considerando a atribuição das notas 1 (nada frequente) ou 2 (pouco frequente), chama a atenção o fato de 13 dos 40 alunos usarem pouco a internet para realizar pesquisas acadêmicas, o que parece ser índice relativamente alto (32,5\%), considerando a quantidade de informações que a rede disponibiliza na área de estudos linguísticos e literários. Talvez isso se deva ao pouco conhecimento de sites confiáveis que possam ser utilizados para estudo ou ao pouco estímulo e orientação que os estudantes recebem dos professores para a realização de consultas na internet.

Os dados coletados reforçam, assim, a relevância de pesquisar quais são as necessidades e interesses dos estudantes quanto ao uso da internet, já que essas informações, do ponto de vista do professor universitário, podem auxiliar na identificação de sites que contribuam para o processo de aprendizagem. Nessa perspectiva, a última pergunta do questionário apresenta informações importantes ao indicar alguns conteúdos que despertam o interesse dos alu-

8 A maior parte dos alunos que frequentam o curso de Letras na FCLAr são de outras cidades do estado ou até mesmo de estados vizinhos a São Paulo.

9 Cabe ressaltar que nenhum aluno indicou outro uso da internet além dos apresentados no questionário. 
nos e que poderiam ser considerados por professores no momento de selecionar sites de apoio à pesquisa ou, ainda, que poderiam ser tomados como referência na construção de uma interface virtual que propicie o intercâmbio de ideias, a construção de conhecimento interdisciplinar (língua, literatura, cultura, política, etc.) e a prática da língua-alvo.

As respostas dadas à última pergunta indicam que os alunos valorizam diversos conteúdos relacionados à sua área de estudo. Em geral, pode-se dizer que houve uniformidade na avaliação dos cinco primeiros conteúdos, vistos pelos alunos como muito interessantes ou interessantes. Considerada a totalidade de indicações nessas duas categorias, o único conteúdo que apresentou avaliação diferenciada foi o relativo a informações sobre o "mundo dos famosos e afins, nos países de língua espanhola" (apenas 10 dos 40 participantes o consideraram muito interessante ou interessante), conforme ilustra o quadro 1.

Percebe-se que a valorização dos conteúdos relacionados à aprendizagem da língua espanhola (exercícios - escritos ou de áudio - que possam contribuir para aprimorar conhecimentos), bem como dos conteúdos relacionados à literatura espanhola e hispano-americana, está diretamente relacionada ao momento imediato de aprendizagem pelo qual os alunos estão passando. Conteúdos dessa natureza podem propiciar aos alunos uma prática adicional àquela que ocorre na sala de aula. Porém, é preciso lembrar que os estudantes não aprendem diretamente da tecnologia, mas, sim, pensando sobre o que fazem; portanto, seu processo de aprendizagem deve caracterizar-se como essencialmente reflexivo. Nessa perspectiva, é desejável que os sites de consulta estimulem "práticas que envolvam o aluno em uma experiência interativa e colaborativa" (Mayrink, 2009 , p.71), contribuindo para o desenvolvimento de sua autonomia e reflexão crítica sobre seu processo de aprendizagem, o que pode ser alcançado através da criação de espaços de diálogo e interação no próprio site. Desse modo, "os alunos assumem, também, um papel ativo, como construtores e socializadores de conhecimento" (Mayrink, 2009, p.71). 


\begin{tabular}{|l|c|c|c|}
\hline \multicolumn{1}{|c|}{ Áreas de interesse } & $\begin{array}{c}\text { Muito } \\
\text { interessante } \\
(3)\end{array}$ & $\begin{array}{c}\text { Pouco } \\
\text { Interessante } \\
\text { (2) }\end{array}$ & $\begin{array}{c}\text { (1) } \\
\text { interessante }\end{array}$ \\
\hline $\begin{array}{l}\text { Conteúdo relacionado à } \\
\text { aprendizagem da língua } \\
\text { espanhola, com exercícios } \\
\text { - escritos ou de áudio - para } \\
\text { aprimorar seus conhecimentos } \\
\text { na língua. }\end{array}$ & 36 & 3 & 1 \\
\hline $\begin{array}{l}\text { Conteúdo relacionado à literatura } \\
\text { espanhola e hispano-americana. }\end{array}$ & 27 & 8 & 5 \\
\hline $\begin{array}{l}\text { Conteúdo acadêmico } \\
\text { - possibilidade de contato, } \\
\text { intercâmbio, cursos, acesso às } \\
\text { pesquisas, etc. de universidades } \\
\text { situadas em países de língua } \\
\text { espanhola. }\end{array}$ & 21 & 16 & 3 \\
\hline $\begin{array}{l}\text { Conteúdo informativo de diversos } \\
\text { países de língua espanhola } \\
\text { (política, cultura, economia, } \\
\text { atualidades, etc.). }\end{array}$ & 11 & 20 & 4 \\
\hline $\begin{array}{l}\text { Conteúdo relacionado a } \\
\text { entretenimento (filmes, livros, } \\
\text { música, programas de televisão, } \\
\text { programas de rádio, etc.). }\end{array}$ & & 25 & 1 \\
\hline
\end{tabular}

Quadro 1 - Tabulação dos dados referentes à pergunta 5. Fonte: Funes, 2009

Conteúdos de teor acadêmico (informações sobre contato, intercâmbio, cursos, acesso às pesquisas de universidades de países de língua espanhola) foram também considerados altamente interessantes (21 alunos) ou interessantes (16), o que se justifica pelo desejo de grande parte dos alunos de aprofundar seus conhecimentos por contato direto com a língua de estudo e a cultura dos povos nativos.

Finalmente, os conteúdos relacionados a entretenimento (filmes, livros, música, programas de televisão e de rádio, etc.) tam- 
bém receberam especial atenção dos alunos. $\mathrm{O}$ interesse por esse tipo de conteúdo justifica-se pelo momento de aprendizagem que estão vivendo, uma vez que abre possibilidades de contato com o uso autêntico e real da língua. Cabe resgatar Preti (1996, p.26), que reforça a ideia de que as NTICs são "instrumentos estratégicos para atender às necessidades de constante qualificação dos indivíduos numa era industrial e tecnológica, sem barreiras geográficas, onde as informações são transmitidas em tempo real, o que garante que a relação ensino-aprendizagem seja de qualidade sem a necessidade do deslocamento ou de horários fixos, ou seja, transpondo as maiores dificuldades para o acesso à educação”. Possibilitando a superação de barreiras geográficas, a internet permite, também, a aproximação de diferentes culturas e povos no espaço virtual, algo extremamente limitado até alguns anos atrás, quando o acesso a filmes, músicas, programas de rádio ou televisão era restrito, por depender da importação ou gravação direta em fitas cassete ou VHS, em seu país de origem.

\section{Reflexões e desafios no uso de TICs na formação inicial de professores}

Embora constatemos, atualmente, um expressivo uso da internet pelos alunos, penso que é preciso incentivar ainda mais seu uso na formação inicial de professores. Entretanto, é necessário estar atento às dificuldades que podem aparecer no momento de incorporar os diferentes recursos tecnológicos nos programas de ensino superior. Além das limitações técnicas que possam surgir (restrições no acesso ou falta de familiaridade com computadores e outros recursos das NTICs, por exemplo), um fator que pode comprometer o sucesso do processo de ensino-aprendizagem é o preconceito que ainda existe na sua utilização para fins educacionais, especialmente no que diz respeito à implementação de projetos de ensino a distância.

Contudo, vale lembrar que esse novo contexto que estamos vivendo, marcado pelos avanços tecnológicos, nos leva em direção a 
uma redefinição do que é e de como se dá o processo de ensino-aprendizagem. Andrade e Vicari (2003) destacam a importância do modelo de aprendizagem colaborativa, que entende o papel do professor ou tutor como facilitador do processo de interação entre a comunidade que se forma. Sendo assim, segundo os autores, o professor deixa de ser visto como um transmissor de conhecimentos e passa a ser um gerenciador de entendimento, mediando todo o processo de aprendizagem (em cujo centro se encontra o aluno) e exercendo a importante função de preparar espaços de diálogo e interação.

Desse modo, se de um lado a conduta e a habilidade do professor estão centradas na capacidade de motivar, apoiar os estudantes, preparar o ambiente de aprendizagem e organizar os materiais, de outro, os alunos são vistos como construtores e socializadores do conhecimento, em uma concepção afinada com a teoria sócio-histórico-cultural de Vygotsky (1998 e 1999).

Nessa perspectiva, as NTICs constituem instrumentos de mediação que podem proporcionar diferentes formas de interação entre os participantes do processo de ensino-aprendizagem. No entanto, não se pode esperar que o mero uso das NTICs como ferramentas de mediação garanta o sucesso da formação de alunos reflexivos. Deve-se considerar uma série de fatores que, se não observados, podem transformar o computador e outros recursos das TICs em "máquinas de ensinar, repetindo os mesmos esquemas do ensino tradicional”, segundo aponta Gomes (2002, p.123). Para evitar isso, continua Gomes, o uso do computador e dos recursos das TICs a ele associados deve acontecer como "organizador de ambientes de aprendizagem em que os alunos são encorajados a resolver situações-problema e o professor é capaz de identificar e respeitar o estilo de pensamento de cada um, ao mesmo tempo em que os convida a refletir sobre o seu pensar (pensamento reflexivo); neste caso o ensino estará sendo inovador". ${ }^{10}$

10 Gomes (2002, p.128) lembra que a comunicação mediada por computadores, "ao contribuir para a construção do conhecimento e o desenvolvimento do aluno, fundamenta-se na abordagem construtivista da aprendizagem, em que o conhecimento é 
As reflexões apresentadas apontam para a relevância do desenvolvimento de um trabalho de conscientização a ser feito com os alunos do ensino superior, especificamente, na formação de professores de espanhol, sobre a importância da incorporação das NTICs no processo de aprendizagem. A contribuição desses recursos para a formação linguística e pedagógica pode revelar-se no desenvolvimento de uma cultura tecnológica que expresse não somente a capacitação técnica, ${ }^{11}$ mas, sobretudo, a construção do conhecimento desses futuros professores, o que passa necessariamente por uma postura epistemológica, isto é, por um conhecimento de seu próprio conhecimento, como lembra Pinto (2002, p.183). O autor ressalta ainda que, "na utilização desses recursos, o que está em jogo não é a maior ou menor eficácia com que são manipulados, ou a presteza e a confiabilidade dos resultados que produzem, mas a possibilidade de serem utilizados como motivo de reflexão e de retomada dos pressupostos da prática docente" (Pinto, 2002, p.185).

Desse modo, o uso da internet e de recursos da TIC na formação inicial de professores pode colaborar para que os futuros docentes estabeleçam relações entre teoria e prática, em uma perspectiva que Barros e Brighenti (2004) definem como simetria invertida, segundo a qual deve haver coerência entre as ações desenvolvidas durante a formação de um professor e o que dele se espera como profissional. Para esses autores,

[...] o professor deverá vivenciar, durante todo o seu processo de formação, atitudes, modelos didáticos, modos de organização que poderão interferir na sua futura prática pedagógica. (Barros \& Brighenti, 2004, p.136)

uma construção realizada pelo sujeito e da qual resulta uma interpretação individual da experiência, legitimada pelos processos de interação social".

11 Cabe destacar a diferença que Pinto (2002, p.180) aponta entre capacitação técnica (absorção de conhecimentos técnicos) e treinamento (a simples repetição de ações, informações e processos, sem que esteja consciente desses atos). 
Portanto, a própria experiência do aluno com o uso das NTICs poderá auxiliá-lo na construção de um novo olhar em torno das novas formas de ensinar e aprender que vão se consolidando na sociedade contemporânea.

\section{Bibliografia}

ALMEIDA, M. E. B. Educação a distância na internet: abordagens e contribuições dos ambientes digitais de aprendizagem. Educação e Pesquisa, v.29, n.2, p.327-40, 2003.

ANDRADE, A. F.; VICARI, R. M. Construindo um ambiente de aprendizagem a distância inspirado na concepção sociointeracionista de Vygotsky. In: SILVA, M. (Org.). Educação on-line: teorias, práticas, legislação, formação corporativa. São Paulo: Loyola, 2003.

BARBOSA, A. F. (Org.). Pesquisa sobre o uso das tecnologias da informação e da comunicação no Brasil: TIC domicílios e TIC empresas 2008. São Paulo: Comitê Gestor da Internet no Brasil, 2009. Disponível em <http://www.cetic.br>. Acesso em 19/7/2009.

BARROS, D. M. V.; BRIGHENTI, M. J. L. Tecnologias da informação e comunicação e formação de professores: tecendo algumas redes de conexão. In: RIVERO, C. M. L.; GALLO, S. (Org.). A formação de professores na sociedade do conhecimento. Bauru: Edusc, 2004.

BRASIL. Ministério da Educação. Portaria n.4.059, de 10/12/2004. BRUNNER, J. J. Educação no encontro com as novas tecnologias. In: TEDESCO, J. C. (Org.). Educação e novas tecnologias: esperança ou incerteza? São Paulo: Cortez, 2004.

FUNES, M. Pesquisa de sites de interesse para a aprendizagem de língua espanhola. Projeto de estágio departamental inédito. Araraquara, 2009. UNESP, FCAr.

GIDDENS, A. Modernidade e identidade pessoal. Diadema: Celta, 1997.

GIUSTA, A. S. Educação a distância: contexto histórico e situação 
atual. In: GIUSTA, A. S.; FRANCO, I. M. (Org.). Educação a distância: uma articulação entre a teoria e a prática. Belo Horizonte: Editora PUC-Minas, p.17-42, 2003.

GOMES, N. G. Computador na escola: novas tecnologias e inovações educacionais. In: BELLONI, M. L. (Org.). A formação na sociedade do espetáculo. São Paulo: Loyola, p.119-34, 2002.

MAYRINK, M. F. As múltiplas realidades do uso de tecnologias no ensino de espanhol da rede pública. In: SOTO, U.; GREGOLIN, I. V.; MAYRINK, M. F.; RANGEL, M. (Org.). Novas tecnologias na sala de aula: (re)construindo conceitos e práticas. São Carlos: Claraluz, p.69-84, 2009.

PINTO, A. C. A experiência reflexiva na formação de professores. In: BELLONI, M. L. (Org.). A formação na sociedade do espetáculo. São Paulo: Loyola, p.169-88, 2002.

PRETI, O. Educação a distância: uma prática educativa mediadora e mediatizada. In: PRETI, O. (Org.). Educação a distância: início e indícios de um percurso. Cuiabá: UFMT, 1996.

VYGOTSKY, L. S. A formação social da mente. 6.ed. São Paulo: Martins Fontes, 1998. . Pensamento e linguagem. São Paulo: Martins Fontes, 1999. 



\title{
O PAPEL dA MEDIAÇÃo PEDAGóGICA EM FÓRUNS EDUCACIONAIS DE CURSOS ON-LINE DE LÍNGUA ESTRANGEIRA
}

\author{
Kátia Silene Gabrielli \\ Pós-graduanda UNESP - Araraquara \\ Bolsista Capes e Capes-DGU (Brasil/Espanha)
}

\section{Considerações iniciais}

Atualmente, o grande desafio quanto à prática docente do professor está frequentemente relacionado ao uso de novas tecnologias educacionais. Isso é um reflexo do desenvolvimento das ciências tecnológicas e da influência que tem causado em diversos processos sociais, inclusive na área educacional. As tecnologias de informação e comunicação (TICs) e, em especial, o computador são ferramentas que podem ser exploradas de diversas maneiras no ensino. A sociedade convive com constantes mudanças, e do homem, bem como do professor, é exigida grande capacidade de adaptação.

Desde o fim da década de 1970, a organização das salas de aula e a definição dos papéis de professor e aluno vêm sofrendo algumas modificações. Com a introdução de novas tecnologias digitais, surgem preocupações em como utilizar esses recursos de maneira mais eficiente no contexto escolar.

De acordo com Leal (2007), ao pensarmos na educação, deparamo-nos constantemente com profissionais que não se sentem preparados para enfrentar essas mudanças e, por isso, sentem di- 
ficuldade para mudar seu plano de aula, metodologia e, inclusive, seu instrumento de trabalho. Dessa forma, o trabalho com as novas tecnologias é visto como um desafio para grande parte dos professores.

Tendo em vista essas preocupações em torno das ferramentas que colaboram diretamente com a formação efetiva do aluno no ambiente virtual, este artigo propõe-se a repensar o papel da mediação em cursos de língua, em especial a mediação pedagógica, considerando a constante mudança e adaptação dos papéis sociais envolvidos nesse contexto.

Para nossa reflexão, tomamos como objeto de análise a mediação nos fóruns de discussão (nomearemos, neste artigo, fóruns educacionais) de um curso de língua espanhola on-line. Escolhemos trabalhar com fóruns educacionais, por esta ser uma das ferramentas mais utilizadas em plataformas virtuais de ensino, uma vez que grande parte das atividades educativas a serem trabalhadas - por exemplo, dúvidas gerais e dúvidas funcionais - costumam ocorrer em fóruns.

Para chegarmos aos resultados sobre a mediação em fóruns educacionais, utilizamos como metodologia a observação participante, que se baseou na análise dos registros obtidos a partir de duas aplicações do curso Español para turismo. Nosso objetivo foi descrever os aspectos implicados na mediação on-line, pelo computador, e, além disso, realizar um mapeamento dos aspectos desse contexto.

\section{Afinal, quais são as características de um fórum?}

Atualmente, estamos muito acostumados a encontrar fóruns de discussão na internet. Podemos achá-los com facilidade, pois é uma ferramenta utilizada para promover debates sobre determinado assunto por meio de mensagens que ficam publicadas em sites e que qualquer pessoa pode comentar.

Hierarquicamente, os fóruns de discussão possuem três níveis de organização: usuários, moderadores e administradores. Os usuários podem acessar e participar do fórum sem a necessidade de fa- 
zer inscrição ou solicitação para participar. Diferentemente dos usuários, os moderadores possuem diversas funções: editar, mover, apagar, adequar o que for necessário na sala de discussão, etc. Já o administrador é responsável pela administração e configuração do fórum, podendo, por exemplo, criar novas salas, bem como, se necessário, bloquear ou expulsar membros que não respeitem as regras, etc.

Ao contrário das salas de bate-papo, também muito utilizadas em cursos on-line, os fóruns são assíncronos, ou seja, são ambientes em que as pessoas interagem por meio de uma rede de computadores a qualquer hora e em qualquer lugar, sem a participação simultânea dos usuários. A linguagem é organizada de forma monológica - ao escrever, o usuário do fórum não tem a resposta imediata do outro -, mas deixa de ser isolada quando começa a interação nas ações seguintes. Com isso, podemos afirmar que o fórum é uma ferramenta interativa, porque nele é possível intercambiar ideias durante um período, isto é, a interação terá prazo maior para acontecer comparada às ferramentas síncronas.

Apesar de ser uma atividade casual, uma ação cotidiana, como escrever um e-mail, o fórum não é uma ação espontânea, pois o usuário tem a opção de ler, reler, reescrever e repensar antes de enviar sua mensagem, e, mesmo depois de enviada, em muitos casos, ele tem, dentro de certo tempo predeterminado pelo moderador, o direito de rever seu texto.

Sobre o gênero fórum eletrônico, Xavier e Santos dizem que:

é um gênero terciário que guarda mais semelhanças com os gêneros primários por serem constituídos basicamente por marcas da oralidade tanto na forma composicional como no tempo de execução, embora a sua concretização se dê pela escrita. Períodos simples e curtos, frases truncadas, preferência por construções verbais na voz ativa, menor densidade informacional, marcas de envolvimento, presença de marcadores conversacionais, entre outras características da oralidade costumam aparecer muito nos fóruns virtuais. (Xavier \& Santos, 2000, p.57) 
Até este momento, falamos sobre fórum de discussão ou fórum de discussão livre comumente encontrado em sites. Todavia, nosso objeto de estudo é o fórum educacional, que, apesar de ter surgido da concepção de fórum de discussão, possui algumas características peculiares. Em decorrência disso, existe a necessidade de utilizar outra denominação para referirmo-nos aos fóruns de ensino-aprendizagem.

No fórum educacional, a organização é diferente. Muitas vezes, uma única pessoa - em geral o professor - assume o papel de administrador e moderador. Outra diferença que merece destaque é que o fórum educacional ocorre dentro de uma plataforma virtual de aprendizagem e, para participar das discussões, o usuário necessariamente deve ser aluno aceito e matriculado em determinado curso. Assim, as pessoas não terão livre acesso às discussões ocorridas dentro do fórum educacional.

Outros aspectos citados são iguais nos dois tipos de fórum, ainda que seja necessário considerar que a linguagem utilizada em um fórum educacional é um pouco mais cuidadosa por parte dos alunos, por se tratar de um ambiente acadêmico, ainda que virtual. Além disso, em um curso de língua a distância, existe a vantagem de trabalhar a língua em uso, isto é, para dar andamento no curso, os alunos necessariamente utilizam a língua-alvo para a comunicação de uma maneira ampla, tanto para desenvolver as atividades quanto para tirar dúvidas, interagir com os colegas, etc.

\section{A mediação em conceitos}

Percebemos que cada vez mais os fóruns educacionais estão sendo usados como principal recurso de cursos a distância, por isso, existe grande preocupação com a mediação no uso dessa ferramenta. Para Gutierrez e Prieto,

A mediação pedagógica parte de uma concepção radicalmente oposta aos sistemas de instrução baseados na primazia do ensino como mera transferência de informação. Entendemos por mediação pedagó- 
gica o tratamento de conteúdos e das formas de expressão dos diferentes temas, a fim de tornar possível o ato educativo dentro do horizonte de uma educação concebida como participação, criatividade, expressividade e relacionalidade. (Gutierrez \& Prieto, 1994, p.62)

\section{Já para Masetto,}

mediação pedagógica é uma atitude, o comportamento do professor que se coloca como facilitador, incentivador ou motivador da aprendizagem, que se apresenta com a disposição de ser uma ponte entre o aprendiz e sua aprendizagem - não uma ponte estática, mas uma ponte "rolante", que ativamente colabora para que o aprendiz chegue aos seus objetivos. (Masetto, 2000, p.144-5)

Para essa definição de mediação, a relação professor-aluno encontra-se mais estreita, pois o docente é visto como personagem essencial para realizar a ação de unir seu aluno ao conteúdo. Disso nos interessa, principalmente, a palavra atitude, que traz o questionamento que será o fio de nossas reflexões: a mediação é uma atitude de quem?

Para nos auxiliar na busca dessa resposta, buscamos a definição de mediação sugerida por Vygotsky:

A transmissão racional e intencional de experiência e pensamento a outros requer um sistema mediador [...]. De acordo com a tendência dominante, até recentemente, a psicologia tratou o assunto de um modo demasiadamente simplificado. Partiu-se da hipótese de que o meio de comunicação era o signo (a palavra ou o som); que, por meio de uma ocorrência simultânea, um som podia associar-se ao conteúdo de qualquer experiência, servindo então para transmitir o mesmo conteúdo a outros seres humanos. (Vygotsky, 1998, p.7)

A partir dessas definições, retornamos à questão anterior de verificar, no contexto dos fóruns educacionais de um curso on-line, se o professor é o único responsável por realizar mediações ou se existe a possibilidade de os alunos as realizarem. Também nos questio- 
namos se as mediações devem ocorrer de forma constante para que ocorra a aprendizagem.

Analisando os conceitos expostos, reformulamos a definição de mediação a fim de verificar nossas hipóteses anteriores. Para nós, mediar é uma relação entre sujeitos (aluno-professor, aluno-aluno) que buscam, dentro de um processo dinâmico, atitudes que colaborem com o desenvolvimento de aprendizagem de todos os envolvidos na situação. Assim, o mediador, seja ele professor ou aluno, poderá incentivar os colegas a buscar novas descobertas, por meio da utilização de materiais e ferramentas disponíveis no contexto em que estão inseridos.

Nos fóruns de aprendizagem, os alunos não precisam pedir autorização para "falar". Como as mensagens ficam expostas a todos os participantes do curso, é possível que um estudante responda a uma dúvida de outro, ou participe de uma discussão, trazendo seu ponto de vista, gerando uma questão e chegando juntos a uma conclusão, mesmo sem a participação do professor.

Durante nossos estudos, deparamo-nos com ocorrências como essa, em que os alunos direcionavam perguntas para os próprios colegas, ou ainda discussões em que o professor não participava diretamente, apenas acompanhava o debate "em silêncio". Nesses casos, os estudantes veem-se como atores de um processo de aprendizagem, em uma situação em que se sentem hábeis e com conhecimentos específicos para trabalhar com os temas.

\section{Algumas mediações em fóruns educacionais}

Para verificar como ocorrem algumas mediações em fóruns educacionais, utilizaremos exemplos reais do curso Español para turismo. Ressaltamos que não foram realizadas alterações nos textos do corpus e que, a fim de manter o anonimato dos participantes do curso, foram utilizados nomes fictícios em nossas análises.

Neste momento, devemos lembrar que o professor não perde espaço no ambiente virtual de aprendizagem. Estamos considerando aqui que, além do professor, o aluno também busca meios de 
expressar "sua voz" nesse processo. O curso on-line apenas colabora para que o estudante encontre esse espaço quase inexistente em uma sala de aula presencial e tradicional, como veremos nos exemplos a seguir:

Exemplo 1. Mediação tipo informação.

\section{Actividad 2}

de Anise Eptm - lunes, 17 de septiembre de 2007, 12:21

Profesor, yo tengo dudas en la actividad 2. Cómo hacer después de encontrar las palabras?

Editar | Borrar | Responder

\section{Re: Actividad 2}

de Marcos Profe EPTM - lunes, 17 de septiembre de 2007, 16:32

Hola Anise! Lo que tenéis que hacer es agregar al Glosario del curso EPT las tres palabras que encontréis difíciles. Para ello vais al Glosario del curso, pincháis en "Agregar entrada", concepto (la palabra), editor de texto (significado de la palabra), Guardar cambios... iy listo!! La palabra estará en nuestro Glosario.

Mostrar mensaje anterior | Editar | Partir | Borrar | Responder

\section{Re: Actividad 2}

de Anise Eptm - martes, 18 de septiembre de 2007, 07:39

Garcias profesor, yo consegui.

Mostrar mensaje anterior | Editar | Partir | Borrar | Responder

Esse exemplo é a descrição de um tópico do Foro general, no qual os alunos postam suas dúvidas referentes ao curso (dúvidas técnicas, prazos de entrega, etc.), mas não sobre o conteúdo acadêmico trabalhado.

No exemplo, destacamos a ocorrência de uma interação comum, isto é, o aluno abriu um tópico intitulado "Actividad 2" para solicitar ajuda dirigida diretamente para o professor. Notamos na análise de nosso corpus que esse tipo de solicitação influencia o tipo de me- 
diação que ocorrerá na sequência, pois o uso do vocativo "profesor", ou simplesmente o nome do professor/tutor, faz com que outros alunos não participem da interação.

O mesmo ocorreu na resposta do professor para autora do questionamento. Todavia, a aluna podia não ser a única que teve essa dúvida. Para a mediação, no caso aluno-professor-aluno, dizemos que ocorreu a mediação do tipo demonstração, pois o docente demonstra o desenvolvimento do tópico em questão passo a passo, facilitando a resolução do problema.

Exemplo 2. Interação aluno-aluno.

\section{Actividad 3 tipos de turismo}

de Patrícia Eptm - miércoles, 12 de septiembre de 2007, 11:30

Prof. Marcos

La actividad 3 después de ser respondida presenta los errores, me gustaria saber se tienes acceso automático a las mias respuestas o se necesito hacer algo más.

Gracias Patrícia

\section{Editar | Borrar | Responder}

\section{Re: Actividad 3 tipos de turismo}

de Andréa Eptm - jueves, 13 de septiembre de 2007, 23:20

Patrícia,

Sabería decirme lo que pasa con el video, pues no comprendo lo que tenemos que hacer... ¿Puedes ayudarme?

Gracias,

Andréa

Mostrar mensaje anterior | Editar | Partir | Borrar | Responder

No exemplo 2, o fórum utilizado foi o mesmo do exemplo anterior, destinado a perguntas gerais, mas, nesse caso, percebemos uma interferência na relação de mediação aluno-professor. Na primeira mensagem do fórum, a aluna direciona a pergunta ao professor. Porém, uma segunda responde a mensagem do fórum não com 
uma resposta, mas aproveitando o conhecimento da colega, que já havia conseguido resolver a questão proposta na atividade, para sanar sua dúvida sem ter que se dirigir ao professor diretamente.

Esse exemplo remete-nos ao processo de ensino-aprendizagem presencial, no qual, muitas vezes, o aluno prefere tirar uma dúvida com o colega que está sentado ao lado. Várias questões envolvem essa preferência de posicionamento do estudante, como vergonha de se expor para a turma e para o professor, timidez, comodidade, etc.

No exemplo 2, a aluna Andréa não respondeu a dúvida de Patrícia. Tal fato nos levou a questionar se, em interações como essas, haveria mediação se a aluna respondesse à questão da colega, visto que uma pergunta feita por outro aluno poderia estar colaborando com a aprendizagem do companheiro, seja facilitando, motivando ou incentivando. Apenas com esse exemplo não é possível chegar a uma conclusão, pois faltam dados para uma afirmação. Dessa forma, consideraremos o exemplo a seguir para dar continuidade às reflexões que postulamos aqui.

Exemplo 3. Trabalho em grupo.

Re: GRUPO 3 - LIVIA - AMANDA - NIVEA [Turismo cultural] de Nívea Epti - martes, 25 de septiembre de 2007, 10:19

Hola, niñas ¡buenos días!

¿Como vamos hacer la tarea de la semana 4? Vamos a buscar informaciones sobre el tipo de turistas y cual alojamineto sería lo mejor para ellos y despues cambiamos las informaciones antes de enviarlas? Y Lívia ¿Cuál tipo de turista elegió?

Son informaciones simples o tenemos que escoger el alojamiento y el destino de los turistas?

Bejos para las niñas...

Nívea

Mostrar mensaje anterior | Editar | Partir | Borrar | Responder

\section{Re: GRUPO 3 - LIVIA - AMANDA - NIVEA [Turismo cultural]}

de Amanda Epti - martes, 25 de septiembre de 2007, 19:25

Lívia y Nívea

Creo que tendremos que buscar informaciones sobre alojamientos para 
los tipos de turistas eligidos. En principio me gustaría hacerlo sobre la pareja en luna de miel, mas creo que no tiene nada a ver con turismo cultural. Qué piensan? Sería mejor hacerlo sobre estudios, entones? Aguardo respuesta.

Besos

Amanda

Mostrar mensaje anterior | Editar | Partir | Borrar | Responder

Re: GRUPO 3 - LIVIA - AMANDA - NIVEA [Turismo cultural]

de Nívea Epti - martes, 25 de septiembre de 2007, 22:39

Hola, niña!

Envié un mensaje para Lívia que prefiere un grupo de turista de la tercera edad, tudo bien para mi. Pero tiengo una duda vamos a buscar informaciones cada una sobre un tipo de turista y después cambiamos las informaciones antes de enviarlas? Ya estoy buscando informaciones sobre una típica familia aficionada en la playa... pero yo puedo buscar un otro tipo de turista.

Besos ¡hasta mañana!

Nívea

Mostrar mensaje anterior | Editar | Partir | Borrar | Responder

Re: GRUPO 3 - LIVIA - AMANDA - NIVEA [Turismo cultural]

de Livia Epti - miércoles, 26 de septiembre de 2007, 11:17

Hola Chicas!

Creo que podríamos hacer una clase por persona para ganarmos tiempo.

Amanda, no veo impedimento o inconsistencia en una pareja que quiere hacer un paseo turístico en su luna de miel.

Entonces podríamos quedar así:

Lívia: 2. Un grupo de turistas de la tercera edad (viajes del INSERSO);

Amanda: 1. Una pareja en su luna de miel;

Nívea: 6. Una típica familia de clase media aficionada a la playa.

Besos e vamos colocar las manos en la masa!!!

Lívia

Mostrar mensaje anterior | Editar | Partir | Borrar | Responder

Re: GRUPO 3 - LIVIA - AMANDA - NIVEA [Turismo cultural]

de Amanda Epti - miércoles, 26 de septiembre de 2007, 11:58

¡Hola chicas!!!

Nos quedamos como Lívia ha colocado, entonces.

¡Avante y suerte a todas!

Besos

Amanda

Mostrar mensaje anterior | Editar | Partir | Borrar | Responder 
Esse último exemplo é um trabalho em grupo para o qual os alunos deveriam, juntos, eleger três tipos de turistas de uma lista (casal em lua de mel, grupo de turistas da terceira idade, grupo de adolescentes, estudante estrangeiro aprendiz de espanhol, aventureiro, e típica família de classe média que gosta de praia) e, em seguida, buscar o alojamento mais adequado para cada um deles.

É interessante notar que nesse contexto, em que o professor não interage diretamente com os alunos, é comum que um deles coordene os trabalhos. Não há votação, tampouco discussão para entrarem em acordo sobre o coordenador, mas um estudante assume naturalmente o comando da tarefa.

Quando o professor é claramente o mediador da interação, as palavras e o tempo verbal utilizados são característicos da posição hierárquica que possui em sala de aula. Retomando algumas expressões do primeiro exemplo, o professor auxilia a aluna com a expressão "o que você tem que fazer é..." ("lo que tenéis que hacer es...”), como uma receita culinária em que algumas ordens são dadas. Ele também utiliza o presente do indicativo como imperativo em "vais al Glosario del curso, pinchais em 'Agregar entrada"”.

Em atividade em grupo, apesar de haver um aluno que assume o papel de coordenador, em nenhum momento ele, ou outro estudante, utiliza formas verbais ou expressões que indiquem uma ordem. Por exemplo, para responder perguntas, ainda que o aluno utilize verbos no presente do indicativo, é comum a utilização de expressões e formas indiretas que indiquem uma sugestão, como no exemplo: "creo que tendremos que buscar..." respondendo a uma pergunta da colega.

Para sugerir algo para o andamento da atividade, os alunos utilizam o "creo que..." e também verbos no futuro do pretérito: "creo que podríamos hacer una clase por persona, para ganarmos tiempo", "sería mejor hacerlo sobre estúdios, entones (sic)?".

É interessante notar que o aluno também usa expressões de incentivo, assim com o professor mediador - "vamos a colocar las manos en la masa" e "Avante y suerte a todas!". Caracterizando, assim, o aluno também como um incentivador e motivador da aprendizagem. 


\section{O aluno é um colaborador ou um cooperador?}

A partir das discussões abordadas nos blocos anteriores, debatemos sobre a questão da diferença dos conceitos colaboração e cooperação, a fim de poder verificar se, nos casos de mediação entre iguais (aluno-aluno), o que ocorre é colaboração ou cooperação. Para Kenski (2003),

Colaboração difere da cooperação por não ser apenas um auxílio ao colega na realização de alguma tarefa, ou indicação de formas para acessar determinada informação. Ela pressupõe a realização de atividades de forma coletiva, ou seja, a tarefa de um completando o trabalho de outros. (Kenski, 2003, p.112)

Já para Maçada \& Tijiboy (1998), a diferença fundamental está no fato de que, para haver colaboração, um indivíduo deve interagir em algum tipo de ajuda, mútuo ou unilateral. Por outro lado, para existir cooperação, deve haver, além da interação, a colaboração, objetivos comuns, atividades e ações conjuntas e coordenadas. Para Alava (2002), a diferença entre colaboração e cooperação ocorre da seguinte forma: a cooperação é realizada por um grupo de atores que aceitam apoiar-se mutuamente em busca de objetivos pessoais, e a colaboração supõe a busca por um grupo de atores de um objetivo comum.

Leal (2007) conclui que colaborar é a ação entre sujeitos que buscam um mesmo objetivo em uma atividade, isto é, em um trabalho conjunto em que as atividades realizadas contribuem entre si. Por sua vez, a autora afirma que cooperar vem da ação de um sujeito que age a favor da atividade de outro sujeito, auxiliando-o de alguma forma para obter uma informação ou realizar uma tarefa.

A partir dessas diferentes perspectivas, podemos concluir que, em um fórum educacional, os alunos estão reunidos com interesses comuns e, portanto, a partir do momento que um grupo discute sobre um mesmo assunto, eles estão colaborando entre si. Já quando um aluno ou o professor é solicitado por outro estudante ou faz co- 
mentários sobre a participação de alguma pessoa, ele está cooperando.

Portanto, o aluno e o professor podem assumir os dois papéis, mas a ação de cooperar está mais presente no papel do mediador (seja ele o professor ou o aluno). Essa diferenciação depende do contexto da aula, pois o estudante consegue interagir com seus colegas colaborando, em alguns momentos, na discussão do problema, assim como pode cooperar a partir do momento em que dá contribuições e feedbacks, isto é, quando assume o papel de mediador.

A seguir, há mais um exemplo de trabalho em grupo, retirado de um fórum de trabalho, no qual o professor não aparece em nenhum momento, e os alunos aproximam-se do fechamento da atividade. Nessa sequência, apenas uma aluna faz considerações a respeito do andamento da tarefa.

Exemplo 4. Destaque de um coordenador.

Re: GRUPO 3 - LIVIA - AMANDA - NIVEA [Turismo cultural]

de Amanda Epti - viernes, 28 de septiembre de 2007, 13:47

Nívea

Muy buena su investigación. Me pareció bastante interesante los comentarios sobre la parte cultural...

Pienso que es importante no nos olvidarmos que éste es nuestro tema del trabajo final... También sigo haciendo de la misma manera...

Besos

Amanda

Mostrar mensaje anterior | Editar | Partir | Borrar | Responder

Re: GRUPO 3 - LIVIA - AMANDA - NIVEA [Turismo cultural]

de Amanda Epti - viernes, 28 de septiembre de 2007, 13:49

Nívea

Me parece buena las informaciones que habéis encontrado, pero creo que no podemos nos olvidar de asociar todo al nuestro tema final: Turismo Cultural.

Piense en esto...

Besos

Amanda

Mostrar mensaje anterior | Editar | Partir | Borrar | Responder 
Re: GRUPO 3 - LIVIA - AMANDA - NIVEA [Turismo cultural]

de Amanda Epti - viernes, 28 de septiembre de 2007, 13:36

Queridas amigas

Ya he conseguido algunas informaciones sobre lo que los alojamientos para una pareja en su luna de miel, pero sigo buscando algo más para perfeccionar nuestro trabajo.

Estoy a organizar todo. Así que termine voy a inviarles para que den un vistazo antes de concluirmos el trabajo.

Besos

Amanda

Mostrar mensaje anterior | Editar | Partir | Borrar | Responder

Nessas mensagens, notamos claramente que a participação da aluna traz muitas colaborações em "Ya he conseguido algunas informaciones..., pero sigo buscando algo más para perfeccionar nuestro trabajo" e, em todos os momentos que utiliza o termo "nuestro trabajo", ela claramente está colaborando com os componentes do grupo, pois seu trabalho está ajudando no resultado final.

Já nas passagens: "Muy buena su investigación. Me pareció bastante interesante los comentarios" e "Piense en esto...", a aluna está cooperando, isto é, ela está auxiliando outro aluno para a realização de uma tarefa.

\section{Considerações finais}

Para esta breve reflexão, partimos do fato de que o fórum educacional é, hoje, uma das ferramentas mais utilizadas em cursos on- line. Sendo assim, as pesquisas relacionadas a seu funcionamento podem contribuir para o melhor aproveitamento do fórum no processo de ensino-aprendizagem. Como recurso assíncrono, que se inseriu de maneira geral e rápida, ele foi muito bem aceito por usuários comuns da internet. É tido como uma das ferramentas que melhor funciona em cursos a distância, pois os debates virtuais ficam suspensos até a participação do próximo aluno, sem que se perca o calor da discussão. 
Contudo, nas diversas leituras realizadas para chegar à questão que norteou nossos estudos, nosso interesse sobre a mediação remetia-nos sempre ao papel do professor como principal mediador. O que nos estimulou a realizar esta pesquisa foram as amostras de interações em fóruns educacionais no curso Español para turismo, das quais utilizamos alguns exemplos para esta reflexão. Dentre as amostras coletadas para a pesquisa, foi possível constatar que a estrutura do curso propunha a realização de atividades em grupo e, para isso, os alunos deveriam definir metas, discutir propostas, planejar e concluir uma tarefa. Assim, o que encontramos foi a ausência do professor nas atividades em grupo.

A partir de nossa proposta de classificação dos tipos de mediação, verificamos que alguns tipos de intervenção, atribuídos até então somente ao professor do curso, também aconteciam em fóruns nos quais o professor não participava diretamente por meio de envio de mensagens. Essas mediações eram realizadas pelos próprios alunos, que muitas vezes assumiam o papel de coordenador do grupo, mesmo sem saber. Essa observação sobre a coordenação não é uma regra, pois também encontramos casos em que um aluno, mesmo com poucas participações, realizou mediações.

Para concluir, reafirmamos que buscamos com esta reflexão não negar a importância do professor no fórum educacional, mas destacar que o processo de ensino-aprendizagem pelo uso de novas tecnologias não possui as mesmas características que a sala de aula presencial. Portanto, devemos buscar a melhor forma de aproveitar essas ferramentas, seja em mediações com a presença do professor, seja em mediações feitas por alunos.

O uso de novas tecnologias no ambiente educacional é uma realidade que vem crescendo substancialmente com o passar dos dias e parece estar acompanhando o desenvolvimento das tecnologias de uma forma geral. Por essa razão, desconsiderar esse fato em pesquisas acadêmicas pode acarretar um mau uso dessas ferramentas que muito têm a contribuir no campo educacional. A partir da utilização dos fóruns para fins pedagógicos, juntamente com o estudo linguístico possibilitado por essas ferramentas, é possível aprimo- 
rar os conhecimentos desse recurso e, assim, melhorar pedagógica e tecnicamente nossa habilidade docente.

\section{Bibliografia}

ALAVA, S. et al. Ciberespaço e formações abertas: rumo a novas práticas educacionais? Porto Alegre: Artmed, 2002.

GUTIERREZ, F.; PRIETO, D. A mediação pedagógica: educação a distância alternativa. Campinas: Papirus, 1994.

KENSKI, V. M. Tecnologias e ensino presencial e a distância. Campinas: Papirus, 2003.

LEAL, V. P. L. V. O chat quando não é chato: o papel da mediação pedagógica em chats educacionais. In: ARAÚJO, J. C. (Org.). Internet $\mathcal{E}$ ensino: novos gêneros, outros desafios. Rio de Janeiro: Lucerna, 2007.

MAÇADA, D. L.; TIJIBOY, A. V. Aprendizagem cooperativa em ambientes telemáticos. Brasília, 1998. IV Congresso Ribie. Disponível em <http://mathematikos.psico.ufrgs.br/textos/aprendizagem_cooperativa.pdf $>$. Acesso em fevereiro de 2009.

MASETTO, M. T.; MORAN, J. M.; BEHRENS, M. A. Novas tecnologias e mediação pedagógica. Campinas: Papirus, 2000.

VYGOTSKY, L. S. A formação social da mente: o desenvolvimento dos processos psicológicos superiores. São Paulo: Martins Fontes, 1998.

XAVIER, A. C.; SANTOS, C. F. O texto eletrônico e os gêneros de discurso. Veredas: revista de estudos linguísticos, v.4, n.1, p. 51-7, 2000. Disponível em <http://www.revistaveredas.ufjf. br/volumes/6/artigo5.pdf>. Acesso em 25/7/2009. 


\title{
USO DO CHAT NA SALA DE AULA DE LÍNGUA ESPANHOLA: UMA PROPOSTA A PARTIR DA ANÁLISE DO GÊNERO
}

\author{
Crisciene Lara Barbosa-Paiva \\ Pós-graduanda UNESP - Araraquara \\ Bolsista Capes e Capes-DGU (Brasil/Espanha)
}

A internet, como espaço didático-pedagógico, permite a inserção do aluno em distintos contextos, em situações reais de uso da linguagem e em interações com pessoas de diferentes culturas e países, especialmente quando se trata de ensino e aprendizagem de língua estrangeira. Envolver o aluno de espanhol como língua estrangeira (E/LE) em tarefas pedagógicas com ferramentas digitais, como chat, fórum, blog e e-mail, além de ser motivador, permite-lhe utilizar a língua-alvo em contextos reais de interação, por meio da escrita, e desenvolver maior autonomia sobre sua aprendizagem, mediante postura mais colaborativa.

O objetivo deste trabalho é discutir o papel do chat no âmbito educativo a partir da análise da linguagem manifestada nesse gênero. Como desdobramento da discussão teórica e da análise de algumas marcas de estilo no chat educacional, formulamos uma proposta pedagógica para o ensino e a aprendizagem de línguas pela internet em sala de aula. ${ }^{1}$

O chat analisado faz parte de um curso de espanhol ministrado a distância em um ambiente virtual de aprendizagem. Esse curso, intitulado Español para turismo (doravante EPT), foi oferecido

1 Este artigo consiste em um recorte de minha pesquisa de mestrado, em andamento. 
como um curso de extensão de quarenta horas no segundo semestre de 2007, pela Faculdade de Ciências e Letras da Universidade Estadual Paulista, campus Araraquara. A participação no chat foi uma das atividades obrigatórias do curso, baseado em uma metodologia de trabalho por tarefas, as quais deveriam ser discutidas entre alunos e entre alunos e professor via chat. Tomaremos como base teórica as concepções de gênero e de estilo formuladas por Bakhtin (2003), que entende que "onde há estilo há gênero" (p.268). Para a análise do estilo, verificaremos se os elementos encontrados por Araújo \& Biasi-Rodrigues (2007) no chat aberto (emoticons, repetição de letras e de sinais de pontuação, uso da letra " $K$ ", marcas de nasalidade) estão presentes também no chat educacional.

Para a análise do corpus, entre 31 sessões de chat educacional que compõem todo o curso EPT, escolhemos duas (a quinta e a sétima sessões), por acreditarmos que sejam as que melhor representam as regularidades observadas nos bate-papos. Ressaltamos que não foram realizadas alterações nos textos do corpus, uma vez que, como afirma Marcuschi (2005, p.63), trata-se de "uma linguagem escrita não monitorada, não submetida a revisões, expurgos ou correções. É uma linguagem em seu estado natural de produção”. Cabe ressaltar que as amostras de dados citadas para exemplificação, neste trabalho, não seguem necessariamente a rígida ordem de sucessão de mensagens enviadas no momento da conversação on-line. Além disso, o critério de definição da amostra foi o de isolar fragmentos que permitissem a identificação do estilo do chat educacional.

\section{Uma reflexão sobre o uso da internet em sala de aula}

García del Dujo (2004, p.16) reconhece que as novas tecnologias são mais que meros instrumentos, são mais que um simples equipamento. $\mathrm{O}$ autor vê nelas um valor agregado que as convertem em ferramentas que geram cenários para a ação educativa. Burbules e Callister (2001, p.18-9) afirmam que as novas tecnologias não só constituem um conjunto de instrumentos, mas também 
um ambiente - um espaço, um ciberespaço - no qual ocorrem as interações humanas. Trata-se de um ambiente cooperativo em que os pesquisadores e criadores compartilham ideias, coconstroem novos conceitos e interpretações e um espaço em que as pessoas agem e interagem. Segundo os autores, isso leva a pensar em um papel diferenciado das tecnologias na educação: o de um "território potencial de colaboração", um lugar no qual é possível desenvolver atividades de ensino e aprendizagem. Essas colaborações têm capacidade de reunir pessoas que jamais poderiam interagir face a face.

Com relação ao uso de tecnologias digitais em ambiente de aprendizagem de línguas, Trenchs Parera (2001a e 2001b) sustenta que, ao usar a comunicação eletrônica, os alunos podem conseguir mais autonomia e mais controle sobre seu próprio processo de aprendizagem. Além disso, Sancho Gil (2006) afirma que toda atividade mediada por computador pressupõe o desenvolvimento de capacidades cognitivas e metacognitivas (resolução de problemas, entre outras). Nessa perspectiva, em qualquer área do currículo escolar, essa atividade tem o potencial de melhorar a motivação, o rendimento e as habilidades cognitivas dos alunos.

Observamos, atualmente, que, com o desenvolvimento de centros de recursos e outros espaços multimídias (assim como meios tecnológicos), a sala de aula já não é o lugar exclusivo da aprendizagem formal. Isso implica um crescimento das reflexões sobre as situações de ensino-aprendizagem que, até pouco tempo atrás, tendiam a considerar como aprendizagem formal somente aquela que ocorria em situação de aula presencial (Dabène \& Cols apud Degache, 2003).

A aprendizagem autônoma ou autoformativa, que, atualmente, se revela como um dos campos mais promissores em didática de línguas, supôs a criação de novos espaços pedagógicos para a aprendizagem, denominados "sala ou espaço multimídia", "midiateca", "centro de recursos", "centro de autoaprendizagem”, segundo Denise \& Mangenot e Quintin \& Depoyer (apud Degache, 2003). Foi no final do século XX que se passou a entender que a finalidade da 
aprendizagem de uma língua estrangeira consiste em converter um aluno em um usuário-aprendiz-autônomo durante toda a sua vida, capaz de utilizar e interagir significativamente em situações diversificadas de comunicação (Degache, 2003).

Diante desse novo cenário na ação educativa, podemos afirmar que há um continuum no aprendizado, que vai desde a aprendizagem heterodirigida até a autodirigida. Na aprendizagem heterodirigida, a determinação dos objetivos e dos conteúdos, a seleção das estratégias de ensino (a metodologia) e de progressão, a escolha dos suportes, a gestão de aprendizagem (ritmo, momento, lugar) e a avaliação das aquisições apresentam-se alheias ao aprendiz, já que a instituição e o docente têm o poder de decisão sobre todos esses aspectos. No outro extremo do continuum, a aprendizagem autodirigida, desde o início, fixa o objetivo de conceder ao aprendiz o poder de tomar decisões para que possa "aprender sem que o ensinem" (Degache, 2003).

\section{Gênero discursivo e estilo}

De acordo com Bakhtin (2003, p.261-2), o conteúdo temático, o estilo e a construção composicional estão "indissoluvelmente ligados" no enunciado e são definidos pela especificidade de um determinado campo da comunicação. $\mathrm{O}$ autor reconhece que cada enunciado é individual, mas que cada área de uso da língua elabora seus "tipos relativamente estáveis" de enunciados, os quais ele denomina "gêneros do discurso".

Além de reconhecer, como Bakhtin, os três elementos que caracterizam os gêneros do discurso, Marcuschi (2008, p.150) acrescenta a "função" dos gêneros, argumentando que eles são entidades dinâmicas, históricas, sociais, situadas, comunicativas, orientadas para fins específicos, ligadas a determinadas comunidades discursivas e a domínios discursivos, recorrentes e estabilizadas em formatos mais ou menos claros. Devemos, assim, conceber os gêneros como entidades dinâmicas, como formas culturais e cognitivas de ação social corporificadas de maneira particular na linguagem, 
pois, segundo esclarece Marcuschi (2008), os gêneros não são modelos estanques ou estruturas rígidas.

Baseando-se em Bronckart, Marcuschi (2008) menciona também o fato de que os gêneros têm uma identidade e são entidades poderosas, que, na produção textual, nos condicionam a escolhas, as quais não podem ser totalmente livres nem aleatórias no que diz respeito ao léxico, ao grau de formalidade ou aos temas.

Para Bakhtin (2003), o estilo está indissoluvelmente ligado aos gêneros do discurso. Para o autor, todo enunciado é individual e, por isso, pode refletir a individualidade do falante ou do escritor. Porém, ele defende que nem todos os gêneros "são igualmente propícios a tal reflexo da individualidade do falante na linguagem do enunciado" (ibidem, p.265).

\section{Chat: um novo gênero}

No que diz respeito à definição de chat, percebemos que há três formas de entendê-lo:

a) como um ambiente síncrono, onde estão ressaltadas as características físicas relacionadas ao ambiente informático, isto é, ao meio físico da comunicação, como uso de computador conectado à internet, número de participantes, sala de bate-papo;

b) como um gênero;

c) como uma conversação, já que são realizados em tempo real, embora sejam essencialmente escritos.

Destacamos que essas definições não são excludentes e que, do nosso ponto de vista, é necessário pensar em uma definição mais completa, que incorpore as três perspectivas mencionadas.

López García, Marcuschi e Sanmartín Sáez adotam a definição do chat que destaca o meio físico de comunicação. A proposta de López García (2005, p.98) define chat como um "tipo de comunicação interpessoal cuja principal característica diferenciadora é que se produz de modo síncrono, isto é, os participantes da comunicação conectam-se em um mesmo momento para participar ativa- 
mente do discurso". ${ }^{2}$ Para o autor, diferentemente do que ocorre em e-mail e fóruns, por exemplo, no chat é necessário que haja a presença ativa dos usuários. Já para Sanmartín Sáez (2007, p.9), "como o próprio nome indica, o chat (voz inglesa que siginifica 'conversa', 'bate-papo' ou 'conversação') supõe intercâmbio comunicativo entre vários interlocutores através de internet". Por fim, na visão de Marcuschi (2005, p.27), o chat corresponde aos "ambientes em salas de bate-papo entre várias pessoas simultaneamente ou em ambiente reservado". Ao propor breve definição de chat aberto, o autor menciona que se refere a "inúmeras pessoas interagindo simultaneamente em relação síncrona e no mesmo ambiente" (ibidem, p. 28).

A concepção de chat como gênero corresponde ao olhar de Araújo (2005), Mayans (2002), Sanmartín Sáez (2007), Marcuschi (2005), Sá \& Melo (2003) e Crystal (2002).

Araújo argumenta que o chat é a transmutação do diálogo cotidiano, de sua esfera de origem para a esfera eletrônica, a web. $\mathrm{O}$ autor observa que as marcas do diálogo permanecem nele, embora pareçam "gerar uma nova formatação ao diálogo cotidiano", o que o levou a considerar o chat como um gênero emergente (Araújo, 2005, p.94).

Sanmartín Sáez (2007, p.83) afirma que o chat corresponde a um novo discurso: a conversação coloquial gráfica. Para ele, trata-se de um gênero com suas regras e codificação social que remete, metaforicamente, em uma perspectiva sociolinguística, a uma espécie de "subcomunidade de falantes" que utiliza uma variedade linguística, compartilha algumas normas de uso e um sentimento de pertencimento a um grupo: "internautas" ou "chateiros". A autora acrescenta que "também se poderia classificar o chat como uma espécie de gênero, abstração ou categorização sociocultural” (ibidem, p. 83).

Do ponto de vista de Marcuschi (2005, p.28), "os gêneros denominados chats são na realidade bate-papos virtuais em tempo real (on-line)", e para Sá \& Melo (2003, p.49), o chat é um produto de

2 Tradução da autora. 
uma interação e um novo gênero discursivo. Crystal (2002, p.153) usa o termo genérico chat para fazer referência "ao discurso eletrônico de vários participantes de âmbito universal, seja em tempo real ou não".

$\mathrm{Na}$ terceira forma de classificação, o chat é definido como uma “conversação", "bate-papo” ou "comunicação” (Sá \& Melo, 2003; Mayans, 2002; Sanmartín Sáez, 2007; Marcuschi, 2005; Yus, 2001; Rodríguez Illera \& Escofet Roig, 2008). Para vários autores, o chat é considerado como síncrono (Yus, 2001; López García, 2005; Marcuschi, 2005). No entanto, Sá \& Melo (2003) entendem que a natureza do chat é "quase síncrona", ao passo que outros autores, conforme expõe Crystal (2002, p.194), observaram que "as conversações síncronas por computador têm uma natureza assíncrona”.

Conforme mencionamos anteriormente, parece não haver uma rigidez que imponha a classificação dos chats em apenas uma dessas categorias, pois algumas definições compõem conceitos "híbridos”. Assim, quando ocupa dois ou mais lugares, podemos hierarquizar os aspectos mais salientes de cada classificação: na primeira, trata-se dos aspectos do meio físico de comunicação; na segunda, destacam-se os traços definidores do gênero chat; e, na terceira, observa-se a recorrência de definições que usam o termo "conversação" ou "comunicação" para designar algo que é realizado, essencialmente, por escrito. Verificamos, ainda, que, na última forma de classificação, alguns autores (Yus, 200; Crystal, 2002; Sá \& Melo, 2003; Sanmartín Sáez, 2007) ressaltam o aspecto de "novidade da linguagem", da "comunicação" e do "discurso" que surge com esse gênero.

\section{O estilo do chat aberto}

Os estudos de Araújo \& Biasi-Rodrigues (2007) constataram que as marcas deixadas pela transmutação podem revelar o estilo do gênero chat. Assim, os emoticons, as repetições de letras e de sinais de pontuação, os usos da letra " $K$ " e as marcas de nasalidade 
mostram-se como elementos estilísticos do chat aberto, que constitui uma das modalidades do gênero.

\section{Emoticons e imagens}

As informações paralinguísticas, encontradas em situações comunicativas presenciais (como o barulho do ambiente, os gestos, a expressão facial de sentimentos) ficam ausentes durante as interações eletrônicas. Por essa razão, os usuários dos chats elaboraram estratégias para preencher essas lacunas. Assim, há as "curiosas" combinações entre sinais de pontuação, letras, números e outros caracteres disponíveis nos teclados dos computadores, denominadas emoticons (Araújo \& Biasi-Rodrigues, 2007).

\section{Repetições de letras e de sinais de pontuação}

Segundo Araújo \& Biasi-Rodrigues (2007, p.84), os chats também transmitem sentimentos por meio da repetição de letras ou de sinais de pontuação. Essas marcas podem indicar espanto ou representar euforia e gritos. Os autores afirmam que os emoticons e as repetições de letras e sinais de pontuação são marcas de uma cultura digital ou de uma cultura em uma realidade virtual e reconhecem que as estratégias de repetição de letras e de sinais de pontuação "tentam imprimir na interação virtual as marcas próprias da oralidade" (ibidem, p.85).

\section{Usos da letra "k"}

Araújo \& Biasi-Rodrigues (2007) estudaram a repetição do "k", após constatar a alta frequência de uso dessa letra no chat. Observaram que ela tem sido utilizada para substituir as letras com o fone$\mathrm{ma} / \mathrm{k} /$. Assim, elaboram a equação $K=q u$ e $K=$ c e afirmam que as escolhas linguísticas, representadas por essa equação, poderiam estar associadas à tendência da abreviação, prática muito recorrente no chat. 


\section{Marcas de nasalidade}

Para Araújo \& Biasi-Rodrigues (2007, p.88), a representação da nasalidade é mais uma marca "bastante curiosa na escrita dos chats". Seus estudos demonstraram que -naum é o mais utilizado para marcar a nasalidade, seguindo a forma -um e, finalmente, o segmento $-\tilde{n}$ (quase inexistente). Os autores afirmam que a escrita digital vai adquirindo características próprias, afastando-se da forma canônica em função da nova mídia e da necessidade de aproximar a escrita da fala, ou vice-versa, e em função de uma comunicação síncrona mediada pelo computador em rede e de usuários que procuram desenvolver habilidades para "vencer as barreiras do tempo enquanto falam-escrevem" (ibidem, p.89).

\section{Análise do estilo no chat educacional}

Partindo da discussão apresentada acima, propomo-nos, aqui, a identificar quais elementos definem e caracterizam o estilo no chat educacional. Para tanto, partiremos da análise de excertos retirados da quinta e sétima sessões de chats do curso EPT, na qual o tutor, Marcos, dialoga com seus alunos, Tadeu e Regina.

Exemplo 1. Quinta sessão.

20:41 Regina: "DOMICILIO = HORTALEZA 16 7D

20:42 Regina: creo que la calle sea hortaleza

20:42 Marcos: bien Regina... Ya tienes 1 punto!!!!

[...]

20:49 Tadeu: Reginaaaaaaaaaaaaaaaaaaaaa

20:49 Marcos: ... un poco raro, lo sé!

20:49 Tadeu: que cosa locaaaaaaaaa

20:50 Regina: hauehuaehuaehuaeuhae

20:51 Marcos: aprender una lengua extranjera significa tb compreender las "rarezas" del otro... 
[...]

20:57 Tadeu: Holaaaaaaaaaaaa

20:57 Tadeu: Reginaaaaaaa

20:57 Regina: 20:52 Tadeu: pero "Regina, quedase alli"

20:57 Regina: ???

Nesse exemplo, observamos a utilização de letras maiúsculas, que indicam ênfase dada às palavras, e a repetição de letras e de sinais de pontuação e onomatopeia, que representam, por meio da escrita, um som de admiração. Notamos que o sinal de exclamação apresenta seu valor de acordo com os padrões da escrita normativa. No entanto, o mesmo não ocorre com os sinais de interrogação, pois percebemos que sua repetição no exemplo 1 expressa a indagação de Regina, que não entende o porquê de Tadeu pedir-lhe que fique na sala de chat.

Com relação à repetição de letras, notamos que a estratégia pode representar euforia ou ênfase na frase "que cosa locaaaaaaaaa" e, nos demais casos (Holaaaaaaaaaaaa; Reginaaaaaaa), representa gritos, já que a intenção de Tadeu era chamar a atenção de Regina. Essa análise corrobora as afirmações dos autores Hilgert (2000), Crystal (2002), Sanmartín Sáez (2007), Sá \& Melo (2003) e Araújo \& Biasi-Rodrigues (2007) com relação ao uso de sinais de pontuação em chats.

Exemplo 2. Quinta sessão.

20:30 Marcos: ¡CHIC@S! (que tal si Regina?)

20:31 Regina: mejor...

20:31 Regina: ;)

20:31 Marcos: ;) Por hoy creo que está bien. Hemos trabajado bastante y habéis empezado las actividades y eso es muy bueno... los héroes del sábado!!!! 
No segundo exemplo, encontramos dois emoticons, que se localizam no início de cada turno. Possivelmente, a intenção de Regina e Marcos no uso desses emoticons foi de manifestar sentimentos um para o outro. Segundo Mayans (2002, p.63), o emoticon ;) representa um rosto sorridente que pisca um olho, utilizado, com frequência, para denotar cumplicidade, ironia, zombaria, uma piscada maliciosa, entre outros significados. Observamos, também nesse exemplo, o uso de maiúsculas com o objetivo de enfatizar. Segundo Yus (2001), qualidades vocais, como o grito, são expressadas com o uso de maiúsculas. Porém, no exemplo 2, acreditamos que o tutor Marcos não gritaria com seus alunos, o que nos leva a entender seu uso, aqui, como forma de dar ênfase ao que é escrito.

\section{Exemplo 3. Sétima sessão}

17:49 Marcos: el encuentro de sábado será por la mañana... por lo del festivo de la patria... así aprovechamos todos mejor el "descanso nacional"!! jejejeje...

17:50 Regina: jajajaja

17:50 Regina: hay encuentro este sábado?

17:51 Marcos: sí... por la mañana...

17:51 Marcos: aunque tengo la impresión que estaré mas solo que la una...

17:51 Marcos: jejejejeje...

17:52 Regina: jajajaja

Fato que nos chamou a atenção durante as análises foi o uso de onomatopeias, que representam, por meio da escrita, uma maneira de suprir a falta de um recurso sonoro. No exemplo 3, percebemos que elas são usadas para representar as risadas, e é interessante notar que a onomatopeia foi escrita levando em consideração o sistema fonético da língua espanhola. Mayans (2002) também observou 
o uso de onomatopeias em chats escritos em espanhol. O autor afirma que, no chat, essa figura de linguagem é uma das formas de transmitir ações, mas é válido para um reduzido número delas. Podemos observar que, no nosso corpus, o participante recorre a uma das onomatopeias exemplificadas por Mayans (2002, p.52) para representar o riso (jajajaja) que, segundo o autor, "resulta significativa dentro do registro simbólico das convenções culturais e dos meios de comunicação da língua castelhana”.

\section{Proposta pedagógica para aprendizagem de espanhol como língua estrangeira (E/LE)}

Partindo do aparato teórico discutido neste trabalho e da análise de estilo no chat educacional, podemos afirmar que o gênero chat educacional, bem como outras modalidades de grupo de discussão e os demais gêneros digitais emergentes, podem ocupar importante espaço na educação. Especificamente no ensino e aprendizagem de línguas estrangeiras, entendemos que o chat educacional oferece duas possibilidades.

A primeira seria usar o chat como ferramenta da web, que permite que o aluno interaja e se comunique com outros aprendizes na língua-alvo. Com essa ferramenta, o estudante pode praticar a língua escrita em contextos reais de uso e de interação, e desenvolver uma aprendizagem mais autônoma e colaborativa, o que condiz com a proposta de Badia (2005), que sustenta que os estudantes devem colaborar para aprender.

A segunda possibilidade para o ensino e aprendizagem de línguas estrangeiras seria trabalhar questões linguísticas com os alunos, ou seja, analisar o estilo de linguagem do chat, observando os recursos estilísticos do gênero, já que estilos e gêneros são indissolúveis, tornando-se inviável um estudo do primeiro desvinculado do segundo, como lembra Bakhtin (2003). Além disso, podem-se comparar os estilos dos diferentes gêneros digitais, explicar suas finalidades, seus usos e analisar o contexto de condições de produção do discurso de cada gênero. 
Portanto, acreditamos que é possível propor uma aprendizagem construtiva e significativa com o uso da ferramenta e gênero chat. Trenchs Parera (2001a, p.24) argumenta que, para que a aprendizagem seja construtiva, o aprendiz deve assumir um papel ativo. Para a autora, as novas tecnologias - correio eletrônico, chats ou web - facilitam o fluxo da informação e a comunicação, tornando essas interações necessárias para a aprendizagem significativa da língua. A autora acrescenta que a utilização das novas tecnologias nas escolas pode favorecer uma aprendizagem construtiva que se contrapõe à aprendizagem mais tradicional baseada na instrução programada.

\section{Considerações finais}

Podemos afirmar que, a partir de nossa análise, o estilo do chat educacional apresenta particularidades próprias, uma vez que não encontramos todos os elementos estudados por Araújo \& Biasi-Rodrigues (2007). Os emoticons, as repetições de letras e de sinais de pontuação, o uso de maiúsculas e onomatopeias mostraram ser elementos estilísticos do chat educacional.

O desafio que se coloca para o professor de ensino de línguas diante do cenário de novas tecnologias e gêneros discursivos é de explorá-las não só como ferramenta potencial para a educação, mas também no âmbito do estudo dos novos gêneros discursivos, da linguagem, observando seu estilo. O reconhecimento do estilo dos gêneros digitais dá-se pela inclusão dos alunos no chat e, consequentemente, na sociedade digital, pois, como afirma Bakhtin (2003), muitas pessoas que dominam uma língua sentem total impotência em alguns campos da comunicação porque não dominam, na prática, as formas de gêneros de determinadas esferas. Assim, quanto melhor dominamos os gêneros, mais livremente os empregamos.

Defendendo uma perspectiva sociodiscursiva (Bronckart, 1999), podemos acrescentar que a atividade de linguagem em sala de aula deve ter em vista a inclusão do aluno na construção do conheci- 
mento e sua efetiva inserção social, que se funda na apropriação dos mais diversos gêneros e de estratégias de textualização.

A educação escolar do século XXI tem importantes desafios a cumprir. Com certeza, promover um ensino mais colaborativo e autônomo, que ensine ao aluno "aprender a aprender" (Badia \& Monereo, 2005; Trenchs Parera, 2001b) é o que uma sociedade comunicativamente globalizada espera dos alunos, e usufruir do enorme potencial educativo e comunicativo que a internet apresenta é fazer uso do que já está definitivamente instalado em nossa cultura.

\section{Bibliografia}

ARAÚJO, J. C. A conversa na web: o estudo da transmutação em um gênero textual. In: MARCUSCHI, L. A.; XAVIER, A. C. (Org.). Hipertexto e gêneros digitais: novas formas de construção do sentido. 2.ed. Rio de Janeiro: Lucerna, 2005.

; BIASI-RODRIGUES, B. Questões de estilo no gênero chat aberto e implicações para o ensino de língua materna. In: ARAÚJO, J. C. (Org.). Internet e ensino: novos gêneros, outros desafios. Rio de Janeiro: Lucerna, 2007.

BADIA, A. Aprender a colaborar con internet en el aula. In: MONEREO, C. Internet y competencias básicas: aprender a colaborar, a comunicarse, a participar. Barcelona: Graó, 2005.

BADIA, A.; MONEREO, C. Aprender a aprender a través de internet. In: MONEREO, C. Internet y competencias básicas: aprender a colaborar, a comunicarse, a participar. Barcelona: Graó, 2005.

BAKHTIN, M. Os gêneros do discurso. In: Estética da criação verbal. 4.ed. Trad. do russo Paulo Bezerra. São Paulo: Martins Fontes, 2003.

BRONCKART, J. P. Atividade de linguagem, textos e discurso: por um interacionismo sócio-discursivo. Trad. A. R. Machado. São Paulo: Educ, 1999. 
BURBULES, N. C.; CALLISTER, T. A. Educación: riesgos y promesas de las nuevas tecnologías de la información. Barcelona: Granica, 2001.

CRYSTAL, D. El lenguaje e internet. Trad. espanhola de Pedro Tena. Madri: Cambrigde University Press, 2002.

DEGACHE, C. Entorno multimedia, autoformación y enseñanza de lenguas. In: LÓPEZ ALONSO, C.; SÉRÉ, A. (Ed.). Nuevos géneros discursivos: los textos electrónicos. Madri: Biblioteca Nueva, 2003.

GARCÍA DEL DUJO, A. Formación permanente y nuevas tecnologías. In: ; MARTÍN GARCÍA, A.; PÉREZ GRANDE, M. D. Procesos de formación on-line. Salamanca: Amarú, 2004.

HILGERT, J. G. A construção do texto "falado" por escrito: a conversação na internet. In: PRETI, D. (Org.). A fala e a escrita em questão. São Paulo: Humanitas, 2000.

LÓPEZ GARCÍA, G. Modelos de comunicación en internet. Valencia: Tirant lo Blanch, 2005.

MANSUR, A. Los nuevos entornos comunicacionales y el salón de clase. In: LITWIN, E. Tecnologías educativas en tiempos de internet. Buenos Aires: Amorrortu, 2005.

MARCUSCHI, L. A. Gêneros textuais emergentes no contexto da tecnologia digital. In: ___ X XAVIER, A. C. (Org.). Hipertexto e gêneros digitais: novas formas de construção do sentido. 2 . ed. Rio de Janeiro: Lucerna, 2005.

. Gêneros textuais no ensino de língua. In: Produção textual, análise de gêneros e compreensão. São Paulo: Parábola, 2008.

MAYANS I PLANELLS, Joan. Genero chat o como la etnografía puso un pie en el ciberespacio. Barcelona: Gedisa, 2002.

RODRÍGUEZ ILLERA, J. L.; ESCOFET ROIG, A. La enseñanza y el aprendizaje de competencias comunicativas en entornos virtuales. In: COLL, C.; MONEREO, C. (Org.). Psicología de la educación virtual: aprender y enseñar con las tecnologías de la información y la comunicación. Madri: Morata, 2008. 
SÁ, M. H.; MELO, S. Del caos a la creatividad: los chats entre lingüistas y didactas. In: LÓPEZ ALONSO, C.; SÉRÉ (Ed.). Nuevos géneros discursivos: los textos electrónicos. Madri: Biblioteca Nueva, 2003.

SANCHO GIL, J. M. De tecnologías de la información y la comunicación a recursos educativos. In: SANCHO GIL, J. M. (Coord.). Tecnologías para transformar la educación. Madri: Unia/Akal, 2006.

SANMARTÍN SÁEZ, J. El chat: la conversación tecnológica. Madri: Arco Libros, 2007.

TRENCHS PARERA, M. Tecnologías digitales para un cambio educativo en el aprendizaje de lenguas. In: TRENCHS PARERA, M. T. (Ed.). Nuevas tecnologías para el autoaprendizaje y la didáctica de lenguas. Lleida: Milenio, 2001a.

TRENCHS PARERA, M. Las aplicaciones pedagógicas del correo electrónico en las aulas de idiomas. In: (Ed.). Nuevas tecnologías para el autoaprendizaje y la didáctica de lenguas. Lleida: Milenio, 2001b.

YUS, F. Ciberpragmática: el uso del lenguaje en internet. Barcelona: Ariel, 2001. (Ariel Linguística). 


\section{SOBRE OS AUTORES}

\section{Ana Maria de Senzi Moraes Pinto}

Mestre em Linguística e Língua Portuguesa e doutoranda em Estudos Literários pela Faculdade de Ciências e Letras da UNESP - Araraquara, onde também é professora assistente no departamento de Letras Modernas, área de Língua e Literatura Alemã. Trabalha principalmente com os seguintes temas: história do cinema alemão, pesquisa de material didático para o ensino de língua alemã, elaboração de arquivos iconográficos e pesquisa sobre o romance contemporâneo de adolescência.

E-mail: anamariasenzi@gmail.com.

\section{Anise A. G. D'Orange Ferreira}

Doutora em Letras Clássicas e em Psicologia Experimental pela USP. É professora assistente doutora da Faculdade de Ciências e Letras da UNESP - Araraquara, responsável por disciplinas de língua e literatura gregas. Tem experiência na área de Linguística, com ênfase em Linguística Aplicada, e suas pesquisas têm foco nos seguintes temas: internet, educação a distância, ensino instrumen- 
tal de línguas, ensino a distância e instrução tecnológica, ensino de língua e literatura gregas.

E-mail: anise@fclar.unesp.br.

\section{Beatriz Sainz}

Doutora, atualmente é professora do departamento de Teoría de la Señal, Comunicaciones y Ingeniería Telemática da Universidad de Valladolid (Espanha). Desenvolve pesquisa nas áreas de educação a distância, ambientes virtuais de ensino-aprendizagem e desenvolvimento de hardware e software para provedores de serviço da Sociedad de la Información na área de telecomunicações. Integra, como pesquisadora, o grupo de pesquisa espanhol Sociedad de la Información.

E-mail: beasai@yllera.tel.uva.es.

\section{Cibele Cecílio de Faria Rozenfeld}

Mestre em Línguística de Ensino e Aprendizagem de Línguas pela Universidade Federal de São Carlos e doutoranda do programa de pós-graduação em Linguística e Língua Portuguesa da Faculdade de Ciências e Letras da UNESP - Araraquara, na área de ensino-aprendizagem de línguas. Bolsista CNPq. Suas pesquisas giram em torno dos seguintes temas: ensino e aprendizagem de língua alemã, crenças, ensino intercultural e ensino de línguas mediado por novas tecnologias.

E-mail: cibeleroz@gmail.com.

\section{Crisciene Lara Barbosa-Paiva}

Graduada em Letras (Português-Espanhol) pela UNESP - São José do Rio Preto, e mestranda do programa de pós-graduação em Linguística e Língua Portuguesa da Faculdade de Ciências e Letras da UNESP - Araraquara. Membro da equipe brasileira do 
Projeto de Cooperação Internacional com a Espanha Capes-DGU n.123/06. Bolsista CNPq e Capes-DGU (Brasil/Espanha). Desenvolve pesquisa na área de ensino-aprendizagem de línguas e uso de novas tecnologias.

E-mail: crisbarbosa.paiva@gmail.com.

\section{Daniel Mill}

Doutor em Educação pela Universidade Federal de Minas Gerais, com estágio de doutorado nas universidades Paris VIII e Paris X. É professor da Universidade Federal de São Carlos, onde trabalha como gestor de EaD e coordena o grupo de estudos e pesquisas sobre educação a distância. Suas preocupações em torno das atividades de ensino, pesquisa e extensão voltam-se para as áreas: gestão e planejamento de sistemas de educação a distância, tecnologia, trabalho docente, tempo, espaço, relações sociais de sexo (gênero), gestão do ensino-aprendizagem, políticas públicas em $\mathrm{EaD}$, mentes e máquinas, letramento e inclusão digital.

E-mail:mill@ufscar.br.

\section{Guilherme Ribeiro Rostas}

Mestre pelo programa de pós-graduação em Educação da Universidade Federal do Maranhão e especialista em Avaliação Educacional pela mesma universidade. É professor do Instituto Federal de Educação, Ciência e Tecnologia do Maranhão (IFMA), campus São Luís - Centro Histórico. Possui experiência na área de educação, com ênfase em avaliação de sistemas, instituições, planos e programas educacionais, e atua, principalmente, nos segmentos: educação profissional a distância e superior, currículo, avaliação educacional e tecnologia educacional.

E-mail:rostas@ifma.edu.br. 


\section{Isadora Valencise Gregolin}

Doutora em Linguística e Língua Portuguesa pela Faculdade de Ciências e Letras da UNESP - Araraquara. É professora do departamento de Metodologia de Ensino da Universidade Federal de São Carlos e integra a equipe brasileira do Projeto de Cooperação Internacional com a Espanha Capes-DGU n.123/06 como pesquisadora. Desenvolve o projeto de pesquisa "Exploração didática do ambiente virtual Moodle no ensino/aprendizagem de língua portuguesa e de língua espanhola" e seus temas de interesse são: metodologia e prática de ensino de língua espanhola e uso de novas tecnologias.

E-mail: isadora@ufscar.br.

\section{Kátia Silene Gabrielli}

Graduada em Letras (Espanhol) pela Universidade Federal de São Carlos, mestranda do programa de pós-graduação em Linguística e Língua Portuguesa da Faculdade de Ciências e Letras da UNESP - Araraquara, na área de ensino-aprendizagem de línguas. Membro da equipe brasileira do Projeto de Cooperação Internacional com a Espanha Capes-DGU n.123/06. Bolsista Capes e Capes-DGU (Brasil/Espanha). Desenvolve pesquisa na área de ensino-aprendizagem de línguas e uso de novas tecnologias.

E-mail:kasiga@yahoo.com.br.

\section{Marcelo Rangel}

Mestre pelo programa de pós-graduação em Letras, linha de pesquisa linguística e ensino de línguas (espanhol), da Universidade Federal Fluminense (UFF). É, atualmente, professor de língua espanhola no Programa de Línguas Estrangeira e Materna 
(Prolem) dessa universidade e membro da equipe do Projeto de Cooperação Internacional com a Espanha Capes-DGU n.123/06. Seus temas de interesse são: ensino de língua espanhola e novas tecnologias.

E-mail: promarcelorangel@yahoo.com.br.

\section{Márcia Helena Sauáia Guimarães Rostas}

Doutoranda do programa de pós-graduação em Linguística e Língua Portuguesa da Faculdade de Ciências e Letras da UNESP - Araraquara e bolsista Capes/Dinter/UNESP/UFMA/Cefet-MA. É professora do Instituto Federal de Educação, Ciência e Tecnologia do Maranhão (IFMA), campus São Luis - Monte Castelo, vinculada ao departamento de Ciências Humanas e Sociais. Seus temas de investigação são: uso da ferramenta tecnológica pelo professor como recurso didático-pedagógico e inclusão digital, social, indígena e cultural de jovens e adultos. Tem experiência na área de Educação, com ênfase em currículo e linguagem e em EaD.

E-mail:mrostas@hotmail.com.

\section{María Agustina Navazo}

Psicóloga pela Universidad Complutense Madrid. É professora tutora da Universidad Nacional de Educación a Distancia (Uned), centro associado de Palencia (Espanha) e professora associada da Universidad de Valladolid (Espanha). Seus temas de interesse e pesquisa são: ensino a distância e tele-ensino, com participação em projetos subvencionados por entidades nacionais e europeias.

E-mail:maritina.navazo@gmail.com. 


\section{Maximina Maria Freire}

Doutora em Educação por Ontario Institute for Studies in Education, University of Toronto. É professora assistente doutora na Pontifícia Universidade Católica de São Paulo (PUC-SP). Tem experiência nas áreas de Linguística Aplicada e Educação, atuando em docência, pesquisa, extensão e orientação nos seguintes temas: formação de professores em/para contextos presenciais e digitais, planejamento, implementação e avaliação de ambientes de ensino-aprendizagem mediados pelo computador, Call, CMC, EAD; reflexão e representações sobre a prática docente; abordagem hermenêutico-fenomenológica de pesquisa; ensino-aprendizagem de idiomas; formação de professores na abordagem instrumental e teoria da complexidade. Coordena o Grupo de Estudos sobre a Abordagem Hermenêutico-fenomenológica (GEAHF) da PUC-SP.

E-mail:mmfreire@uol.com.br.

\section{Miguel López Coronado}

Doutor em Engenharia de Telecomunicações pela Universidad Politécnica de Madrid e catedrático da Universidad de Valladolid (Espanha). Coordena o grupo de pesquisa Sociedad de la Información e interessa-se pelos temas: sistemas inteligentes de transporte (ITS), desenvolvimento de projetos de telemedicina e e-learning no novo espaço europeu de educação superior.

E-mail:mlopezcoronado@gmail.com

\section{Mônica Ferreira Mayrink}

Doutora em Linguística Aplicada e Estudos da Linguagem pela Pontifícia Universidade Católica de São Paulo e professora da área de espanhol do departamento de Letras Modernas da Faculdade de Filosofia, Letras e Ciências Humanas da USP. É líder do grupo de 
pesquisa Linguagem, Educação e Virtualidade (LEV) e tem experiência na área de Educação e Linguística Aplicada, com ênfase em formação de professores de língua espanhola. Desenvolve atividades de ensino, pesquisa e extensão, com foco nos seguintes temas: ensino-aprendizagem de línguas (presencial e a distância), formaçãocrítico-reflexivadeprofessores, abordagem hermenêutico-fenomenológica de pesquisa, abordagem instrumental.

E-mail:momayrink@usp.br.

\section{Paulo Oliveira}

Doutor em Linguística Aplicada à Tradução pela Unicamp. É docente da área de Alemão no Centro de Ensino de Línguas da mesma universidade, desenvolvendo pesquisas nas áreas de ensino de línguas (autonomia do aprendiz, ensino a distância), tradução e interpretação (foco em literatura, cinema e televisão) e filosofia da linguagem. Participa de redes de pesquisa de grupos de trabalho do CNPq: Ensino-Aprendizagem de Línguas e Virtualidade; MultiTrad - Abordagens Multidisciplinares da Tradução; Filosofia da Linguagem e do Conhecimento. Na Associação Brasileira de Pós-Graduação em Filosofia (Anpof), é membro do GT Wittgenstein.

E-mail:olivp@unicamp.br.

\section{Rosinda de Castro Guerra Ramos}

Doutora em Linguística Aplicada e Estudos da Linguagem pela PUC-SP, onde é professora titular, editora executiva responsável pela publicação da revista The ESPecialist, membro do conselho editorial da revista Trabalhos em Linguística Aplicada, da Revista Brasileira de Linguística Aplicada e da Revista Moara e integrante do conselho editoral da Revista L@el em (Dis-)curso. Faz pesquisa e docência na área de Linguística Aplicada, com ênfase em línguas 
para fins específicos, atuando principalmente nos temas: abordagem instrumental, formação reflexiva de professores, desenvolvimento de material didático e educação a distância.

E-mail: rramos1@uol.com.br.

\section{Ucy Soto}

Doutora em Linguística e Língua Portuguesa pela Faculdade de Ciências e Letras da UNESP - Araraquara, onde é professora assistente doutora do departamento de Letras Modernas. É líder do grupo de pesquisa Linguagem, Educação e Virtualidade (LEV) e coordenadora da equipe brasileira do Projeto de Cooperação Internacional com a Espanha, Capes-DGU n.123/06. Seus interesses giram em torno da relação entre novas tecnologias e ensino-aprendizagem de línguas, estudos gramaticais e discursivos de língua espanhola e questões relacionadas à formação de professores de línguas estrangeiras.

E-mail: ucy@fclar.unesp.br. 


\author{
SOBRE O LIVRO \\ Formato: $14 \times 21 \mathrm{~cm}$ \\ Mancha: 23, $7 \times 42,10$ paicas \\ Tipologia: Horley Old Style 10,5/14 \\ 2009 \\ EQUIPE DE REALIZAÇÃO \\ Coordenação Geral \\ Tulio Kawata
}





\section{CULTURA}

ACADÊMICA

Editona 